CARLOS EDUARDo STEFEN ELIAS

\title{
IMPARCIALIDADE DOS ÁRBITROS
}

Faculdade de Direito da Universidade de São Paulo

São Paulo

2014 


\section{CARLOS EdUARDo StEFEN Elias}

\section{IMPARCIALIDADE DOS ÁRBITROS}

Tese apresentada ao Programa de Pós-

Graduação em Direito Processual da

Faculdade de Direito da Universidade de São

Paulo, como exigência parcial para a obtenão do título de Doutor em Direito Processual.

Orientador: Prof. Dr. CARLOS AlBERTO CARMONA

Faculdade de Direito da Universidade de São Paulo

São Paulo

2014 
À memória de meu pai, Antonio, e à minha mãe, Domingas, que me fizeram parte do mundo e que serão, para sempre, parte de mim. 


\section{AGRADECIMENTOS}

Agradeço ao Professor CARlos ALberto CARMONA pela orientação acadêmica e profissional. Encontrei nele apoio, incentivo e amizade que me ajudaram - enormemente na elaboração deste estudo.

Aos Professores José Carlos de Magalhães e José Rogério Cruz e TucCi pelas correções e sugestões que fizeram durante o exame de qualificação.

Aos colegas de monitoria, Bruno Barbosa, Fernanda Leão, Lilian Marques, Mateus Carreteiro, Pedro Leite e Ricardo Aprigliano pelos valiosos momentos de aprendizado e pela troca constante de ideias. MATEus, com amizade e entusiasmo, disponibilizou-me diversos textos, todos eles fundamentais para o presente estudo e pelos quais, mais uma vez, agradeço.

A todos os colegas de Marques Rosado, Toledo Cesar e Carmona Advogados, em especial José Machado, Guilherme Quintana, Berardino Neto, Bruno Ferreira e Gustavo RAMOS que, sem jamais perderem a alegria, sacrificaram seu tempo para assumir pesados encargos e corrigir as minhas falhas. Também à DENISE MARTINS, que põe em ordem a vida de todos.

Ao exemplar profissional, José EMILIO NUNES PINTO, pela generosidade e pelas valiosas observações sobre o tema.

À minha família, que suportou a minha ausência.

E à LUCIANA que, corrigindo este estudo com o mesmo amor que corrigiu a minha vida, é a razão de tudo. 


\section{ÍNDICE}

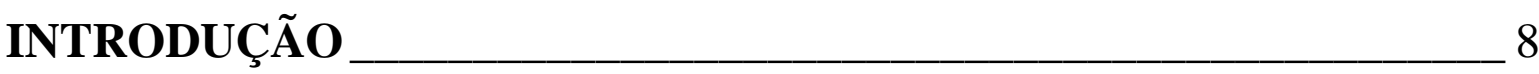

Por que a imparcialidade do árbitro___ 8

Estrutura do presente estudo_______________ 12

\section{CAPÍTULO 1. INSUFICIÊNCIA DA NOÇÃO GENÉRICA E DOS} PADRÕES RELATIVOS À IMPARCIALIDADE DO ÁRBITRO

1.1. Imparcialidade como atributo inerente a qualquer julgador ___ 14

1.2. Transposição da noção genérica de imparcialidade para a arbitragem ___ 17

1.2.1. Transposição não uniforme do conceito de imparcialidade para a arbitragem e o advento das noções de independência e de neutralidade ___ 17

1.2.2. Impossibilidade de identificação precisa dos conteúdos da imparcialidade, da independência, da neutralidade e da sua importância no caso concreto ___ 23

1.3. Tentativas de padronização da imparcialidade do árbitro ___ 27

1.3.1. As diversas técnicas de padronização ___ 27

1.3.2. As técnicas de padronização na experiência da civil law __ 28

1.3.2.1. Equivalência entre causas de recusa ou impugnação do árbitro e do juiz28

1.3.2.2. Tipificação legal dos casos de recusa ou impugnação do árbitro ___ 32

1.3.2.3. Cláusula geral relativa à imparcialidade do árbitro ___ 35

1.3.2.4. Um caso particular: a evolução das técnicas na França____ 36

1.3.3. Técnicas de padronização na experiência da common law ___ 41

1.3.3.1. A experiência inglesa e a disputa entre testes para aferição da imparcialidade __ 41

1.3.3.2. A experiência norte-americana e a vagueza do conceito de "evident partiality" 46

1.3.4. Tentativa de padronização via soft law: as IBA Guidelines on Conflicts of Interest in International Arbitration __ 55

1.3.5. Tratamento da imparcialidade nas instituições arbitrais ___ 59

1.4. Disposições sobre imparcialidade do árbitro na lei e a doutrina brasileira: observações críticas ___ 63 


\section{CAPÍTULO 2. CONTEÚDO DA IMPARCIALIDADE DO ÁRBITRO E SUA OPERACIONALIZAÇÃO PELA APARÊNCIA}

2.1. Função da imparcialidade 71

2.1.1. Modelo processual, participação e influência 72

2.1.2. Preferência, pré-compreensão e imparcialidade 75

2.2. Da subjetividade para a intersubjetividade: imparcialidade, probabilidade e aparência 78

\section{CAPÍTULO 3. CONSTRUÇÃO DA NORMA CONCRETA E SUAS PREMISSAS}

3.1. Conceito de imparcialidade e estrutura normativa 81

3.2. Premissas de estrutura 83

3.2.1. Primeira premissa de estrutura: modelo democrático de processo como forma de orientação na interpretação das hipóteses expressamente previstas e de integração de hipóteses não previstas expressamente 83

3.2.2. Segunda premissa de estrutura: satisfação de postulados hermenêuticos ou das justificativas de "segunda ordem" 89

3.3. O ambiente institucional no qual se desenvolve a arbitragem 94

3.3.1. Um pouco da história da arbitragem comercial internacional e a arbitragem no Brasil: o aumento do número de árbitros e a ineficácia de controles informais 97

3.3.2. A prática arbitral e seu desenvolvimento em um mercado assimétrico 101

3.4. Premissas de conteúdo 108

3.4.1. Categoria (1.1.1) - Relação de trabalho ou societária do árbitro ou de pessoas próximas com a parte ou entidades a ele envolvidas 111

3.4.2. Categoria (1.1.2) - Relação de prestação de serviços do árbitro ou de seu escritório com a parte ou pessoas e entidades com ela envolvidas 118

3.4.3. Categoria (1.2) - Relação familiar ou social do árbitro com pessoas ou entidades envolvidas com a parte 131

3.4.4. Categoria (2) - Relação do árbitro ou seu escritório com o advogado que representa a parte ou seu escritório 136

3.4.5. Categoria (3.1) - Contato anterior do árbitro com o litígio, com causas derivadas ou com questões similares 146

3.4.6. Categoria (3.2) - Posições técnicas defendidas pelo árbitro 153

3.4.7. Categoria (3.3) - Duplo papel do árbitro 155

3.4.8. Categoria (3.4) - Nomeações repetidas do árbitro 159 
3.4.9. Categoria (3.5) - Atuação do árbitro no processo 164

3.4.10. Categoria (3.6) - Particularidades culturais ou cognitivas derivadas da história de vida do árbitro 169

3.4.11. Categoria (3.7) - Nacionalidade do árbitro 172

3.5. Proposta normativa e observador. Diferentes visões? 174

3.6. Roteiro para a criação de normas concretas 178

\section{CAPÍTULO 4. PRINCIPAIS QUESTÕES LIGADAS À IMPARCIALIDADE DO ÁRBITRO} 180

4.1. Padrão de imparcialidade do árbitro e padrão de imparcialidade do juiz 180

4.2. Imparcialidade, independência e neutralidade do árbitro: importância relativa das distinções 184

4.3. Imparcialidade e dever de revelação 191

4.3.1. Natureza e conteúdo do dever de revelação 193

4.3.2. Violação do dever de revelação não dá causa, per se, à parcialidade do árbitro

4.4. Imparcialidade e binômio ciência-aceitação 203

4.5. Os critérios para a análise da imparcialidade devem ser os mesmos para todos os membros do tribunal arbitral. A conclusão de parcialidade de um árbitro invalida a decisão unânime do tribunal arbitral. 207

4.6. Imparcialidade e novas fronteiras 209

4.6.1. Financiamento do litígio por terceiros 209

4.6.2. Imparcialidade e afastamento do advogado 211 


\section{INTRODUÇÃO}

\section{Por que a imparcialidade do árbitro}

A preocupação com a imparcialidade do árbitro torna-se cada vez maior à medida em que cresce a utilização desse método de solução de controvérsias. Isso porque, conformada por influências diversas (e muitas vezes antagônicas) que orbitam entre a autonomia da vontade das partes e as exigências do devido processo $^{1}$, a compreensão da imparcialidade do árbitro pode ser distorcida - com efeitos práticos devastadores para o método - por visões que não outorguem a devida atenção para uma ou para outra influência e, sobretudo, por visões que não reconheçam o ambiente institucional em que tal método é praticado ${ }^{2}$.

As dificuldades se iniciam pela própria conceituação do termo "imparcialidade". Visões que pendem excessivamente para a autonomia das partes irão, despreocupadamente, afirmar que a imparcialidade do árbitro fica prejudicada pelo próprio método de sua escolha, pois as partes "abririam mão" da imparcialidade pelo benefício de nomearem os próprios julgadores ${ }^{3}$. De outro lado, visões que pendem excessivamente para um viés processualista correm o risco de apenas repetir a fórmula de que a imparcialidade

\footnotetext{
${ }^{1}$ Colocando que as duas distinções entre a jurisdição estatal e a jurisdição arbitral são o lugar do seu exercício e a origem da função jurisdicional, das quais derivam uma série de consequências, BRUNO OPPETIT. Teoría del arbitraje (trad. Eduardo Silva Romero et al.). Colombia: Legis Editores, 2006, pp. 61-71. Indo além, para defender uma ordem jurídica autônoma para a arbitragem internacional, EMMANUEL GAILLARD. Teoria geral da arbitragem (trad. Natália Mizrahi Lamas). São Paulo: Atlas, 2014, pp. 31-35. Passando ao largo dessa sistematização, mas fazendo referência aos dois planos em que o método arbitral opera ("private agreement of the parties" e "law of the jurisdiciton"), além de um terceiro plano na arbitragem internacional ("lex mercatoria", "general principles" e "public law"), FRANCIS DONALD DONAVAN. International commercial arbitration and public policy, in New York University journal of international law and politics, v. 27, 1995, pp. 646-649. Especificamente sobre o devido processo legal e a arbitragem, MATTI S. KURKELA; SANTTU TURUNEN. Due process in international commercial arbitration. 2. ed. New York: Oxford, 2010, passim.

${ }^{2} \mathrm{O}$ ambiente institucional e as mudanças ocorridas até a primeira metade dos anos 1990 são tratados de modo sucinto no plano de desenvolvimento da obra de Yves Dazalay; BRYANT G. Garth. Dealing in virtue: international commercial arbitration and the construction of a transnational legal order. Chicago: The University of Chicago Press, 1996, pp. 9-18.

${ }^{3}$ Trata-se da corrente afirmação no sentido de que, na arbitragem, "[t]here is a tredeoff between impartiality and expertise", apresentada originalmente pelo Judge Posner no caso Merit Insurance. Sobre a afirmação e suas consequências, vide HONG-LIN YU; LAURENCE SHORE. Independence, impartiality, and immunity of arbitrators - US and English Perspectives, in International and comparative law quarterly, v. 52, 2003, pp. 947-949; vide, ainda, notas de rodapé $\mathrm{n}^{\text {os }} 288$ e 355 do presente estudo.
} 
significaria a "equidistância" do julgador ante as partes ${ }^{4}$, sem reconhecer que essa ideia não se conforma ao método arbitral (em que o julgador é escolhido por partes que querem vencer a disputa), de modo que todas as premissas, motivos e fatos que influenciaram essa escolha devem ser considerados.

A falta de um suporte teórico-conceitual adequado - sobretudo aplicado a um ambiente institucional peculiar como é o da arbitragem - não enseja apenas a dificuldade de identificação da imparcialidade, mas também a confusão entre uma vaga noção desse instituto com noções também vagas de independência e neutralidade do árbitro. Tudo isso acaba por dificultar a solução de problemas concretos, cuja amplitude e diversidade nenhum dos regramentos ou orientações - uma pletora de leis estatais, regulamentos institucionais, códigos de ética, recomendações profissionais, roteiros de atuação, guias de "melhores práticas" e tudo o mais - conseguiu, até o momento, abarcar. Segundo alguns, tais regramentos não devem alcançar tal objetivo - ou mesmo jamais conseguirão fazê-lo ${ }^{5}$ - para além de um nível geral, que respeite as características e orientações típicas das diferentes experiências jurídicas, sobretudo nacionais ${ }^{6}$.

Impossível negar o papel fundamental das regras sancionadoras da imparcialidade, que cumprem um papel vital ao orientar um comportamento tido como adequado para resguardar a higidez do método arbitral. No entanto, a leitura de regras sem um suporte teórico-conceitual que compreenda as influências jurídicas (processualidade e autonomia da vontade) e o ambiente institucional do método de solução de controvérsias não auxilia na busca de uma orientação minimamente segura para a solução de problemas concretos.

\footnotetext{
${ }^{4}$ CÂNDIDO Rangel Dinamarco. A arbitragem na teoria geral do processo. São Paulo: Malheiros, 2013, p. 27.

${ }^{5}$ KIRSTEN WEISEMBERT. Peace is not the absence of conflict: a response to professor Rogers's article "Fit and function in legal ethics", in Wisconsin international law journal, v. 25, 2007, pp. 113-118.

${ }^{6}$ TOBY LANDAU. The regulation of international commercial arbitration: comparative trends and tensions, in Koichi Hamada; Mitsuo Matsushita; ChiKara Komura. Dreams and dilemmas: economic friction and dispute resolution in the Asia-Pacific, Singapore: Institute of Southeast Asian Studies, 2000, pp. 458460. O autor desenvolveu sua tese, expondo-a em palestra proferida no ICCA 2012 Congress Singapore, em junho de 2012; disponível no endereço eletrônico www.arbitrationicca.org/AV_Library/ICCA_Singapore2012_Toby_Landau_QC.html; consulta em 21.02.2014. Em sentido análogo, defendendo que regras expressas não captariam a gama de situações possíveis de envolvimento entre advogados, seus escritórios, partes e empresas interrelacionadas, o que daria azo somente a maior intervenção estatal na arbitragem, em prejuízo da própria finalidade do instituto, RAPHAËL DE VIETRI; KANAGA DHARMANANDA. Impartiality and the issue of repeat arbitrators: a reply to Slaoui, in Journal of international arbitration, v. 28, 2011, pp. 195-196
} 
Nesse sentido, a referência estabelecida na lei brasileira às regras sancionadoras da imparcialidade do juiz (art. 14 da Lei de Arbitragem - LA) adiciona dificuldade extra tanto para a concepção de um suporte teórico-conceitual relativo ao árbitro quanto para a aplicação desse suporte nas infinitas variáveis encontráveis nas situações concretas. Conforme já afirmado, o modelo processual estatal, embora possa influenciar - e influencie $^{7}$ - o modelo processual arbitral, não se reduz a ele, nem se equivalem juiz (funcionário estatal geralmente sorteado para solucionar uma controvérsia, com poderes conferidos diretamente pela lei) e árbitro (particular geralmente nomeado pelas partes para essa mesma deliberação, com poderes conferidos pela lei e modulados potencial ou concretamente pelas partes). Assim, ainda que se possa obter um suporte teórico-conceitual unificado de imparcialidade para o processo judicial e para o processo arbitral, ele deve ser entendido e aplicado à luz das particularidades desse último (aí inclusos seus atores centrais, os julgadores) e, sobretudo, à luz do ambiente institucional em que sua prática se desenvolve, ambiente esse que compreende os estímulos e interesses que partes, advogados, potenciais árbitros e entidades que prestam serviços ligados à arbitragem possuem, bem como relações que esses mesmos atores protagonizam em um mercado particularíssimo e assimétrico ${ }^{8}$.

Um conceito - embora fundamental para conferir consistência ao tratamento da imparcialidade do árbitro - não é o bastante para, de modo automático, resolver a infinidade de problemas que se colocam na prática da arbitragem. Assim, mais que um trabalho de conceituação, o presente estudo se propõe a tornar esse conceito operativo para o enfrentamento dos problemas possíveis de ocorrer no método arbitral; problemas esses que acabam por ser agravados em razão do afluxo cada vez maior de atores - com

\footnotetext{
${ }^{7}$ Colocando o processo arbitral como sistema, destacando seu fechamento operacional e sua abertura cognitiva, Eduardo de Albuquerque Parente. Processo arbitral e sistema. São Paulo: Atlas, 2012, pp. 40-60. Também sobre o assunto, fazendo ligações entre teoria geral do processo e arbitragem, o já citado CÂNDIDO RANGEl DinAMARCO. A arbitragem... op. cit., passim.

${ }^{8}$ Destacando a existência de competição entre instituições arbitrais e entre profissionais, travada em ambiente desregulado e caracterizado pela assimetria de informação, CATHERINE A. ROGERS. Transparency in internatinal commercial arbitration, in University of Kansas law review, v. 54, 2006, pp. 1313-1319. Em sentido análogo, destacando a competição entre países para atrair a arbitragem como negócio, com resultados para a nomeação de seus nacionais como árbitros, vide CHRISTOPHER R. DRAHOZAL. Arbitrator selection and regulatory competition in international arbitration law, in CHRISTOPHER R. DRAHOZAL; RICHARD W. NAIMARK (Ed.). Towards a science of international arbitration. The Hague: Kluwer Law International, 2004, pp. 174 e 185-186. Para uma visão (otimista) a partir do Brasil, ARNOLDO WALD. A arbitragem e o mercado de trabalho dos advogados, in Revista de arbitragem e mediação, v. 32, 2012, pp. 95-98.
} 
diferentes bagagens ético-culturais (e também jurídicas quando na arbitragem internacional) - no ambiente institucional em que a arbitragem é praticada.

Essa operacionalização do conceito de imparcialidade se dará, segundo a proposta deste estudo, por meio da construção de uma norma concreta ${ }^{9}$, embasada em inferências que o intérprete fará de eventos do mundo fático $(i)$ à luz da estrutura normativa à sua disposição, a qual ele deve respeitar como roteiro para a elaboração da norma (sob pena de propor uma norma inaceitável em nível sistêmico), e (ii) à luz de conteúdos fático-hipotéticos reconhecidos ou reconhecíveis pelas regras aplicáveis, que proporcionarão ao intérprete o insumo para a formação dos silogismos que preencherão a hipótese normativa e apontarão a sua satisfação pelo evento do mundo fático (o que, se não observado, ensejará a inaceitabilidade da norma porque incoerente frente ao evento que visa sancionar). Essas duas instâncias são denominadas, pela ausência de termos mais adequados, como premissas de estrutura e premissas de conteúdo no presente estudo.

Com a proposta de identificar um suporte teórico-conceitual adequado e de apresentar um método para sua operacionalização, este estudo busca prestar auxílio na compreensão da imparcialidade do árbitro, como também servir de apoio para a solução de problemas concretos, seja de modo preventivo, seja de modo corretivo. De fato, não se pode abrir mão da imparcialidade do árbitro, mas também não se pode permitir que a incompreensão do seu conteúdo (ou, pior, a justificativa de sua suposta defesa mascarar a intenção de perturbar o processo arbitral ou anular uma sentença arbitral desfavorável) autorize a utilização de táticas que fragilizem ou limitem o alcance do método arbitral.

\footnotetext{
${ }^{9}$ Vale rememorar a distinção entre regra e norma: a primeira é o texto que será interpretado; a segunda é o juízo, produto da interpretação. Humberto Ávila. Teoria dos princípios. 14. ed. São Paulo: Atlas, 2013, p. 33.
} 


\section{Estrutura do presente estudo ${ }^{10}$}

No capítulo 1 será apresentada a noção genérica e corrente de imparcialidade, bem como as diferentes técnicas para sua padronização nas experiências jurídicas nacionais e institucionais (inclusive com o recurso à soft law). Essa apresentação identificará as técnicas que se valem: $(i)$ do estabelecimento de equivalência entre as causas de recusa ou impugnação do árbitro às hipóteses de afastamento do juiz; (ii) da tipificação legal "fechada" dos casos de recusa ou impugnação do árbitro; e (iii) do recurso a uma cláusula geral vaga, a ser preenchida conforme as circunstâncias do caso concreto. Na medida do possível, serão trazidas decisões de casos reais representativas das técnicas de padronização. Ao final do capítulo, serão feitos apontamentos sobre as considerações da doutrina brasileira a respeito do tema.

O capítulo 2 busca estabelecer um suporte teórico-conceitual para a imparcialidade por meio do reconhecimento do seu conteúdo e da sua função na relação jurídica processual. Será demonstrado que a ideia comumente difundida de imparcialidade como inexistência de "outras influências" - além dos argumentos das partes na decisão do julgador - não se sustenta filosoficamente, linguisticamente, sociologicamente e mesmo juridicamente, pois não reconhece que o fenômeno de conhecer algo - imprescindível (ou mesmo identificável) à ação de valorar e julgar - se apoia nas pré-compreensões do julgador. Por tal razão, com base no modelo democrático de processo e no conceito de influência, o capítulo em questão propõe outra concepção de imparcialidade, ligada à não vedação do julgador à influência dos argumentos das partes para o seu convencimento. No entanto, diante da impossibilidade de aferição in natura desse fenômeno psíquico, o presente estudo propõe a operacionalização desse conceito por inferências realizadas pelo intérprete a partir de eventos reconhecíveis e identificáveis, operacionalização essa pautada, portanto, na aparência.

\footnotetext{
${ }^{10}$ Os termos, conceitos e ideias mencionados nesta Introdução são adequadamente tratados, com exposição detalhada e identificação das referências bibliográficas, nos capítulos de desenvolvimento do presente estudo. A opção pelo não tratamento aprofundado na Introdução visa a evitar a repetição (ou antecipação) desnecessária de argumentação e a sobreposição de referências bibliográficas, o que prejudicaria o desenvolvimento de toda a análise.
} 
O capítulo 3 busca a operacionalização do conceito de imparcialidade sugerido no capítulo anterior, utilizando-se de premissas de estrutura aplicáveis também para o método de padronização escolhido pela LA, e de premissas de conteúdo derivadas da categorização das hipóteses mais comuns de ensejar a aparência de parcialidade (com a eleição de critérios para a análise de cada categoria). A partir dessas premissas, o intérprete poderá propor norma específica a regular o evento concreto, norma essa que poderá ostentar coerência externa (frente ao sistema jurídico aplicável) e interna (frente ao evento normatizado). Conforme já foi colocado, a proposta de norma não pode ignorar o ambiente institucional no qual se desenvolve a arbitragem - e seus personagens, práticas e estímulos -, sob pena de perder a coerência externa ou interna. Como a norma é proposta pelo intérprete (que também possui suas pré-compreensões), o capítulo em questão também trata desse personagem.

O capítulo 4 trata de questões que exsurgem do suporte teórico-conceitual da imparcialidade e do método de operacionalização propostos, os quais ressaltarão a existência de diferentes padrões de análise para o árbitro e para o juiz, além de favorecer sua distinção frente à noção geral de independência, identificada pela doutrina equivocadamente - como fenômeno “objetivo". O capítulo em questão também busca distinguir a imparcialidade do dever de revelação, seja quanto à sua natureza, seja quanto aos efeitos das respectivas violações. Após discutir a possibilidade, à luz da legislação brasileira, de se assumir diferentes padrões de imparcialidade para os membros de um tribunal arbitral, o capítulo é fechado com um olhar sobre novíssimas questões que envolvem o tema em análise.

Importante ressaltar que o presente estudo não trata de questões eminentemente procedimentais, a saber, o tempo, o modo e a forma da apresentação de eventual recusa ou impugnação de árbitro, que podem variar de acordo com o regulamento institucional adotado pelas partes; nem trata propriamente da ação anulatória de sentença arbitral, da qual a violação da imparcialidade é apenas uma das possíveis causas de pedir e cujo procedimento e eficácia da sentença ultrapassam o objeto do presente estudo, já identificado. 


\section{CAPÍTULO 1. INSUFICIÊNCIA DA NOÇÃO GENÉRICA E DOS PADRÕES RELATIVOS À IMPARCIALIDADE DO ÁRBITRO}

\subsection{Imparcialidade como atributo inerente a qualquer julgador}

A raiz moral da imparcialidade é orientada a identificar uma escolha eticamente adequada entre a satisfação de interesses subjetivos total ou parcialmente excludentes, especialmente quando os indivíduos não possuem relação familiar ou íntima ${ }^{11}$. Essa procura não é nova: já na filosofia antiga, Platão e Aristóteles buscaram responder à questão do bem viver (eudamonia) envolvendo a imparcialidade, respectivamente, em um sistema ético baseado em forma e conteúdos ideais ou em resoluções que tomassem como premissa a vida prática $^{12}$. A filosofia moderna aproveitou-se dessa dicotomia original, não descurando do tema da imparcialidade, ora tratando-o como instrumento da preservação da paz individual e social (destacando-o, com isso, da prudência subjetiva aristotélica) ${ }^{13}$, ora como a referência de um observador imaginário para a identificação da ação moralmente adequada (reintroduzindo a subjetividade, ainda que por meio de um sujeito hipotético) ${ }^{14}$, ora alçado

\footnotetext{
${ }^{11}$ Assim, a imparcialidade busca a proporção correta entre a satisfação do "meu" interesse frente ao interesse "dos outros". BRIAN FELTHAM. Partiality and impartiality in ethics, in BRIAN FELTHAM; JOHN COTTINGHAM. Partiality and impartiality: morality, special relationships and the wider world, New York: Oxford, 2010, pp. 2-4.

${ }^{12}$ De modo muitíssimo simplificado, para Platão há o que é imanentemente e idealmente correto e justo, tanto na forma quanto no conteúdo, e é isso o que o homem deve buscar (A república, livros VI e VII, disponível no endereço eletrônico http://www.gutenberg.org/files/1497/1497-h/1497-h.htm; consulta em 21.02.2014), enquanto que, para Aristóteles, o que é correto e justo se revela no equilíbrio que o homem deve estabelecer entre as suas necessidades e as necessidades dos demais ao longo da sua vida (Ética a Nicômano, sobretudo livros IX.8, X.8 e 9, disponível no endereço eletrônico http://classics.mit.edu/Aristotle/nicomachaen.html; consulta em 21.02.2014).

${ }^{13}$ É o que faz Thomas Hobbes, ao tratar das causas, geração e definição da commonwealth. THOMAS HoBBES. The English works. v. III, London: John Bohn, 1840, pp. 113-117, disponível no endereço eletrônico http://files.libertyfund.org/files/585/Hobbes_0051-03_EBk_v7.0.pdf; consulta em 21.02.2014. Para a finalidade do presente estudo, Hobbes foi mais a fundo, apontando que: "An arbitrator, therefore (...) is trusted by the parties to any controversy, to determine the same by declaration of his own judgment therein", que "for in that case he [the arbitrator] is a party, and ough by the same reason to be judged by another", e, principalmente, que "[n]evertheless for the trust reposed in him, and for the equality which the law of nature requireth fim to consider in the parties, he violateth the law, in for favour, or hatred to either party, he give other sentence than he thinketh right." THOMAS HOBBES. The English works. v. IV, London: John Bohn, 1840, p. 106, disponível no endereço eletrônico https://archive.org/stream/englishworksofth029531mbp\#page/n147/mode/2up; consulta em 21.02.2014.
}

${ }^{14}$ ADAM SMITH. The theory of moral sentiments. Indianapolis: Liberty Fund, 1982, p. 148. 
como imperativo categórico (para além de qualquer subjetividade) ${ }^{15}$, ora, ainda, como uma variável dependente da posição e situação entre os sujeitos titulares dos interesses e que visa, no caso concreto, promover a máxima felicidade possível de todos (dando vez a uma análise plurisubjetiva e utilitarista da imparcialidade) ${ }^{16}$.

O auxílio prestado pela filosofia na estruturação de diferentes visões sobre a imparcialidade, dando destaque à conduta eticamente correta do sujeito que deve escolher a prevalência entre o seu interesse e o interesse de outro, é útil também quando, adentrando-se no campo jurídico, faz-se necessário estabelecer as condições para se avaliar a prevalência entre um interesse próprio (juridicamente qualificado) sobre outro ${ }^{17}$.

No entanto, para além da ponderação entre interesses juridicamente qualificados do próprio sujeito frente aos demais, a imparcialidade faz-se vital quando o sujeito não irá apenas avaliar, mas também decidir, em uma disputa estabelecida mediante pleitos formulados por outros sujeitos, qual deles deverá ter seu interesse desatendido (e em qual medida) e qual deles verá seu interesse prevalecer. Em outras palavras, é no momento do julgamento de uma controvérsia - e, portanto, durante o fenômeno estudado pelo Direito Processual - que a imparcialidade torna-se elemento imprescindível.

A ideia de imparcialidade do julgador é tão cara à experiência jurídica e à administração da justiça, que é considerada elemento fundamental tanto pela práxis antiga ${ }^{18}$ quanto pelas correntes metodológicas modernas do Direito Processual ${ }^{19}$. No entanto, a despeito da sua

\footnotetext{
15 "Age como se a máxima da tua acção se devesse tornar, pela tua vontade, em lei universal da natureza". IMMANUEL KANT. Fundamentação da metafísica dos costumes (trad. Paulo Quintela). Lisboa: Edições 70, 2007, p. 59.

${ }^{16}$ A ideia, lançada por Jeremy Bentham, é desenvolvida por John Stuart Mill através do "princípio da máxima felicidade”. JoHn STUART MiLl. Utilitarianism. 7. ed. London: Longmans, Green, And Co., 1879, p. 5; disponível no endereço eletrônico http://www.gutenberg.org/files/11224/11224-h/11224-h.htm; consulta em 21.02.2014.

${ }^{17}$ A inter-relação entre direito e ética é tratada sobretudo na Filosofia do Direito. Para uma análise históricoevolutiva do fenômeno, vide JEAN-CASSIEN BILliER; AgLAÉ MARYIOLI. História da filosofia do direito (trad. Maurício de Andrade). Barueri: Manole, 2005.

${ }^{18}$ Assim noticia PIERo CALAMANDREI. Giustizia e politica: sentenza e sentimento, in Processo e democrazia. Padova: CEDAM, 1954, pp. 46-48.

19 Trata-se do contraditório-influência, que considera a participação dos destinatários da decisão no procedimento da sua produção como método legitimador. Essa participação, comprometida com as regras do discurso, compõe modelo que visa assegurar racionalidade e controlabilidade - e assim a legitimidade - da decisão final. Somente pode ser convencido racionalmente, pelo discurso, o julgador não contaminado de parcialidade. Sobre o tema, Nicolò TROCKER. Processo civile e costituzione: problemi di diritto tedesco e italiano. Milano: Giuffrè, 1974, pp. 114-115.
} 
vital importância, não são muitos os autore ${ }^{20}$ que esboçaram maior preocupação em situar analiticamente a imparcialidade no fenômeno processual, razão pela qual ela é caracterizada ora como condição do exercício legítimo da função jurisdicional ${ }^{21}$, ora como qualidade do julgador ${ }^{22}$, ora como elemento do próprio método processual $^{23}$, sem maiores preocupações com o seu sentido e alcance, identificados sob uma noção genérica de dever do julgador ${ }^{24}$ de decidir - sem prevenção ou juízo prévio - em favor de ou contra pessoas ou coisas ${ }^{25}$ e sem interesse direto e indireto na causa ${ }^{26}$.

No campo normativo, o tema não foi tratado expressamente pela Constituição Federal, razão pela qual é considerado como indiretamente referido mediante a garantia do devido processo (art. $5^{\circ}$, inc. LIV) e pela incorporação ${ }^{27}$ do Pacto Internacional de Direitos Civis e Políticos de 1966, ratificado pelo Brasil (art. $5^{\circ}, \S 2^{\circ}$ ), que prevê que "[t]oda pessoa terá o direito de ser ouvida publicamente e com as devidas garantias por um Tribunal competente, independente e imparcial" ${ }^{28}$, sendo que tanto o Código de Processo Civil $(\mathrm{CPC}-\text { arts. } 134 \text { e 135) })^{29}$ quanto o Código de Processo Penal (CPP - arts. 252 e 253)

\footnotetext{
${ }^{20}$ Exceção seja feita ao estudo de Flávio Galdino que, apoiado em outros autores que também se esforçaram em situar a imparcialidade de modo analítico, defende a existência de três perfis da imparcialidade complementares e intrinsicamente ligados, a saber, imparcialidade-juiz natural, imparcialidade-equidistância e imparcialidade-independência. Flávio Galdino. Princípio da imparcialidade judicial, in RICARDO TORRES; Flavio Galdino; Eduardo KataOKa. Dicionário de princípios jurídicos. São Paulo: Elsevier, 2011, p. 567.

${ }^{21}$ José CARlos Barbosa Moreira. Reflexões sobre a imparcialidade do juiz, in Temas de direito processual - sétima série. São Paulo: Saraiva, 2001, p. 19.

${ }^{22}$ MAURo CAPPELLETTI. Ideologias en el derecho procesal, in Proceso, ideologias, sociedad (trad. Santiago Sentís Melendo). Buenos Aires: Ediciones Juridicas Europa-America, 1974, p. 4. No mesmo sentido, RUI PORTANOVA. Princípios do processo civil, Porto Alegre: Livraria do Advogado, 1995, p. 79.

${ }^{23}$ Sergio José BARberio. La imparcialidad judicial, in Activismo y garantismo procesal. Córdoba: Academia Nacional de Derecho y Ciencias Sociales de Córdoba, 2009, pp. 21-31.

${ }^{24}$ GiUSEPPE ARMANI (Ed.). Enciclopedia del diritto. 2. ed. Italia: Garzanti, 2001, p. 644.

${ }^{25}$ Víctor DE SANTO. Diccionario de derecho procesal. 2. ed. Buenos Aires: Editorial Universidad, 1995, p. 185 .

${ }^{26}$ ANA Prata. Dicionário jurídico. v. I, 5. ed. Coimbra: Almedina, 2008, p. 725.

${ }^{27}$ ARTUR CÉSAR DE SOUZA. A parcialidade positiva do juiz. São Paulo: RT, 2008, p. 57.

28 Decreto de Promulgação $\left(\mathrm{n}^{\circ}\right.$ 592/1992) e Tratado disponíveis no endereço eletrônico http://www.planalto.gov.br/ccivil_03/decreto/1990-1994/D0592.htm; consulta em 21.02.2014.

${ }^{29}$ No CPC de 1939, as causas de impedimento e suspeição do juiz (todas tratadas pelo termo "suspeição") eram estabelecidas nos incisos do art. 184, ao qual o art. 1.033, relativo à "suspeição" do árbitro, fazia referência. No projeto do CPC, ora em fase de aprovação, as causas de impedimento e suspeição do juiz encontram-se, respectivamente, nos arts. 124 e 125.
} 
trazem elencos esparsos de hipóteses de presunção absoluta (impedimento) e de presunção relativa (suspeição) de parcialidade do julgador ${ }^{30}$.

Assim, apesar de o Direito Processual reconhecer a relevância da imparcialidade, ele acaba por não superar a vagueza do termo ao não lhe atribuir um significado conceitual e funcionalmente unívoco nem desenvolver as premissas de sua operacionalização em casos práticos, razão pela qual é possível extrair apenas uma noção genérica do seu conteúdo - a qual deve ser ultrapassada para o seu estudo no âmbito da arbitragem.

\subsection{Transposição da noção genérica de imparcialidade para a arbitragem}

\subsubsection{Transposição não uniforme do conceito de imparcialidade para a arbitragem e $o$ advento das noções de independência e de neutralidade}

Reconhecido o caráter processual da arbitragem ${ }^{31}$, também o árbitro - o julgador nesse método - deve ostentar a qualidade comumente identificada sob a noção genérica de imparcialidade.

A situação de vagueza do termo "imparcialidade", já existente no que concerne ao processo civil estatal, é agravada quando ele é transportado para a arbitragem, em razão da falta de uniformidade com que é tratado na legislação de diversos países, nos regulamentos e códigos de ética das instituições arbitrais e na doutrina dedicada ao tema. Essa falta de uniformidade ora deriva da atribuição de diferentes significados ao termo, ora da confusão

\footnotetext{
${ }^{30}$ Registre-se a tentativa de Mattirolo, resgatada por Vescovi, em congregar as hipóteses em quatro motivos fundamentais, ligados à subjetividade do julgador: afeto, interesse, animosidade e amor próprio. ENRIQUE VesCOVI. Teoría general del proceso, Bogotá: Temis, 1984, p. 149.

${ }^{31}$ Não por outra razão a obra fundamental sobre a arbitragem na doutrina brasileira recebeu o título “Arbitragem e Processo". Não obstante, o autor informa que na LA não existem apenas regras processuais. Carlos Alberto Carmona. Arbitragem e processo. 3. ed. São Paulo: Atlas, 2009, p. 14. De fato, embora a arbitragem tenha origem contratual (pois deriva de negócio jurídico celebrado entre as partes) e envolva também uma relação contratual (o contrato de arbitragem, por força do qual o árbitro e a instituição de arbitragem prestam seu serviço às partes), é na relação jurídica processual, distinta da relação contratual, que a solução do litígio é obtida. Sobre a relação contratual entre instituições, árbitro e partes, vide VALERIO SANGIOVANNI. Il rapporto contrattuale tra gli arbitri e le parti nel diritto tedesco, in I contratti, n. 8-9, 2005, pp. 827-837.
} 
e baralhamento com os termos "independência" e "neutralidade", consagrados na prática da arbitragem comercial internacional.

De fato, algumas legislações nacionais utilizam apenas o termo "imparcialidade" para descrever a qualidade que o árbitro deve ostentar: é o que ocorre na Arbitration Act inglesa (Rule 24.1.a e Rule 33.1.a), na Revised Uniform Arbitration Act norte-americana (Section 12) e no Arbitration Act sueco (Section 8), por exemplo. Outras legislações, por sua vez, não usam o termo "imparcialidade" e fazem referência apenas ao termo "independência": é o caso da Loi Fédérale sur le Droit International Privé suíça (art. 18, $\S 1^{\circ}$ ). Algumas legislações fazem uso de ambos os termos, tais como o Code Judiciaire belga (art. 1690), a Zivilprozessordnung alemã ( $\$ 1036, \mathrm{I})$, a Ley de Arbitraje espanhola (art. 18, $\S 2^{\circ}$ ) e a Lei de Arbitragem brasileira (art. 13, § $6^{\circ}$ ). O Code de Procédure Civile francês ${ }^{32}$ (art. 1452, alínea 2) não fazia referência a nenhum termo; simplesmente determinava que o árbitro informasse, antes de aceitar o encargo, a existência de qualquer causa para sua recusa; essa orientação foi alterada com o advento do Décret $n$. 2011-48, de 13 de janeiro de 2011 que, ao reformar o Code de Procédure Civile, inseriu referência expressa aos termos “imparcialidade" e "independência” (art. 1456, alínea 2). No mesmo sentido, a antiga Lei de Arbitragem Voluntária portuguesa previa apenas que era "aplicável o regime de impedimentos e escusas estabelecido na lei de processo civil para os juízes" (art. 10, nº 1), sendo que, com a nova lei (Lei 63/2011), passou-se a prever expressamente que os "árbitros devem ser independentes e imparciais" (art. 9, no 3). O art. 12.1 da Lei Modelo da Comissão das Nações Unidas para o Direito Comercial Internacional (UNCITRAL) de 1985, com as alterações adotadas em 2006, prevê que o árbitro pode ser “objetado se existirem circunstâncias que possam suscitar dúvidas fundamentadas sobre sua imparcialidade ou independência, ${ }^{, 33}$.

A consulta à doutrina dedicada à análise dos termos nas diferentes legislações não auxilia a interpretação. Segundo certo entendimento, a independência está contida na

\footnotetext{
${ }^{32}$ Até o adento da Loi n. 2007-1787, de 20 de dezembro de 2007, o texto era denominado "Noveau Code de Procédure Civile".

33 Tradução não oficial do texto para o português por Flávia Foz Mange, Gustavo Santos Kulesza, Rafael Bittencourt Silva e Rafael Vicente Soares. Vide COMISSÃo DAS NAÇÕES UNIDAS PARA O DIREITO COMERCIAL INTERNACIONAL. Lei Modelo da UNCITRAL sobre Arbitragem Comercial Internacional 1985, com as alterações adotadas em 2006; disponível no endereço eletrônico http://cbar.org.br/site/wpcontent/uploads/2012/05/Lei_Modelo_Uncitral_traduzida_e_revisada_versao_final.pdf; consulta em 21.02.2014.
} 
imparcialidade ${ }^{34}$; segundo outra orientação, em sentido diametralmente oposto, a imparcialidade é vista como corolário ou consequência da independência ${ }^{35}$; e, por fim, uma terceira orientação busca afastar os conceitos, atribuindo a cada qual um conteúdo específico $^{36}$.

$\mathrm{Na}$ tentativa, senão de definir, de ao menos de apartar os termos para tratá-los de modo teoricamente mais sistemático e praticamente mais operativo - e assim superar a confusão conceitual ensejada pela interpretação direta das leis nacionais - os textos doutrinários pesquisados para a elaboração do presente estudo tendem a reconhecer certas características particulares aos conteúdos da imparcialidade e da independência, separando-os ainda do conteúdo da neutralidade do árbitro.

Tomar por empréstimo um conceito desenvolvido por outro ramo do Direito é o que faz a doutrina arbitral ao se apropriar das noções derivadas do art. 10 da Declaração Universal dos Direitos do Homem, a qual, ao se referir à necessidade de julgamento por um "tribunal independente", interpreta a expressão como "garantia de uma justiça não subordinada a razões de Estado"37. A ideia de não subordinação - relação que pode ser objetivamente

\footnotetext{
${ }^{34}$ É o sentido atribuído pela doutrina à lei sueca, pois " $[t]$ he first two paragraphs of section 8 , and to some extent the third, mention situations where there is not only a lack of impartiality, but also doubt as to the arbitrator's independence. In the Act, independence is not mentioned explicitly, but is included in the concept of impartiality." KAJ HOBÉR. Arbitration reform in Sweden, in Arbitration international, v. 17, n. 4, 2001, p. 362.

${ }^{35}$ É o sentido atribuído pela doutrina à lei suíça, pois "[a]ccording to the drafters of article $180(1)(c)$ of the PILA, impartiality can be considered to the corollary of the independence of an arbitrator or, at least, usually result of such independence". Posição diversa na doutrina suíça, com base na mesma regra, também se verifica, pois "[b]ased upon the fact that the express wording of Article 180(1)(c) of the PILA only refers to independence, some legal commentators have, however, maintained that the standard for independence and impartiality of a party-appointed arbitrator is less strict than one applicable to the chairperson or an arbitrator appointed by third parties or a court". Registro das duas opiniões é dada por GABRIELLE KAUFMANN-KOHLER; BLAISE STUCKI. International arbitration in Switzerland: a handbook for practitioners. The Hague: Kluwer Law International, 2004, p. 42.

${ }^{36}$ Em debate ao projeto de lei que deu origem ao Arbitration Act inglês, Lord Lester sugeriu a introdução de emenda que explicitasse (também) o requisito de independência do árbitro, sob a argumentação de que a imparcialidade não resulta necessariamente na independência e que a ausência expressa ao termo poderia ser contrária à garantia de independência do julgador expressa no artigo $6^{\circ}$ da Convenção Europeia de Direitos Humanos. Sobre o tema, vide RoBERT MERKIN. Arbitration Act 1996, an annotated guide. London: Informa Professional, 1996, pp. 12-13.

37 Orlando Viegas Martins Afonso. Poder judicial - Independência in dependência. Coimbra: Almedina, 2004, p. 67. A apropriação do termo é registrada em transcrição que a doutrina arbitral faz de decisões da Corte Europeia de Direitos Humanos; a exemplo da transcrita em obra dedicada à arbitragem: "in order to establish whether a tribunal can be considered as 'independent', regard must be had, inter alia, to the manner of appointment of its members and their term of office, the existence of guarantees against outside pressures and the question whether the body presents an appearance of independence... As to the question of 'impartiality', there are two aspects of this requirement. First, the tribunal must be subjectively
} 
verificada e demonstrada - foi a base para o preenchimento do conceito de independência na doutrina arbitral. Assim, apesar de os critérios de independência do Poder Judiciário ou de seus membros não se subsumirem aos aplicáveis ao árbitro ${ }^{38}$, a independência deste é compreendida como a ausência de elemento potencialmente condicionante do julgamento, ou seja, a inexistência de um vínculo de subordinação ou de relação pessoal, social, negocial ou financeira objetivamente considerada entre o árbitro e a parte (ou seu advogado $)^{39}$. De modo genérico, entende-se que a falta de independência deriva de relações problemáticas entre o árbitro e uma das partes ou seu advogado, resultantes de acordos ou relações financeiras, ligações de cunho sentimental (amizade ou laços familiares) ou ligação à identificação de grupo (compartilhar nacionalidade ou filiação profissional $)^{40}$.

As justificativas para a identificação e proteção da independência na arbitragem giram entre uma perspectiva que põe foco no livre convencimento do árbitro, que considera que seria difícil a este, ao possuir relação ou vínculo próximo com uma das partes, decidir sem favorecê-la, e uma perspectiva focada na confiança depositada no método de solução de conflitos, que restaria quebrada por conta da relação ou vínculo próximo do árbitro com uma das partes ${ }^{41}$.

Enquanto a independência do árbitro estaria ligada à ausência de conexões próximas com as partes (ou até mesmo com seus advogados), a imparcialidade relacionar-se-ia com o prejulgamento do litígio, ou seja, com uma inclinação ou tendenciosidade inadmissível do árbitro em relação a uma das partes ou à matéria em disputa ${ }^{42}$. Essa inclinação ou tendenciosidade do árbitro para o favorecimento de uma das partes (tratada, na língua inglesa, pelo termo "bias") teria outras origens que não a conexão ou relacionamento entre

free of personal prejudice or bias. Secondly, it must also be impartial from an objective viewpoint, that is, must offer sufficient guarantees to exclude any legitimate doubt in this respect...", conforme aponta LORETTA MALINTOPPI. Independence, impartiality and duty of disclosure of arbitrators, in PETER MUCHLINSKI; FEDERICO ORTINO; CHRISTOPH SCHREUER (Ed.). Oxford handbook of international investment law. New York: Oxford University Press, 2008, pp. 807-808.

${ }^{38}$ Esse tema será tratado nos capítulos 3.3 e 4.1 do presente estudo.

39 Nesse sentido, M. SCOTT DONAHEY. The independence and neutrality of arbitrators, in Journal of international arbitration, v. 9, n. 4, 1992, p. 31.

${ }^{40}$ WILlIAM W. PARK. Arbitrator integrity: the transient and the permanent, in San Diego law review, v. 46, 2009, p. 636.

${ }^{41}$ ChIARA SPACCAPELO. L'imparzialità dell'arbitro. Milano: Giuffrè, 2009, pp. 103-4.

${ }^{42}$ WILLIAM W. PARK. Arbitrator integrity... op. cit., p. 635. 
ambos, podendo ser fruto de preconcepções do árbitro a respeito das partes (preconcepções ligadas, por exemplo, à honestidade, etnia, nacionalidade ou orientação política destas) ou a respeito da matéria envolvida (preconcepções ligadas à predeterminação sincera do árbitro quanto à tese vencedora, sem a análise dos argumentos jurídicos ou dos fundamentos fáticos da pretensão, ou mesmo derivada de corrupção) ${ }^{43}$.

As discussões sobre as características essenciais do árbitro que assegurariam o tratamento equânime das partes, a confiança destas no processo e uma decisão justa não se limitam às noções genéricas de independência e de imparcialidade, envolvendo também - sobretudo nas arbitragens internacionais - a ideia de neutralidade do julgador ${ }^{44}$.

$\mathrm{Na}$ arbitragem, o termo neutralidade é costumeiramente utilizado para designar a ausência de identidade nacional, cultural ${ }^{45}$ ou até mesmo religiosa ${ }^{46}$ entre árbitro e partes. Embora seja um elemento verificável objetivamente, ele se tornou relevante para a arbitragem internacional sob a premissa de que, quanto menor a identidade nacional, política ou religiosa entre partes e árbitro, menores as chances de que este possa ser influenciado por tais fatores ao proferir sua decisão ${ }^{47}$. É entendimento corrente, na arbitragem internacional, que o árbitro escolhido pelas partes serve, idealmente, como um "intermediário" cultural, jurídico e negocial, bem como um "tradutor" da parte que o escolheu ${ }^{48}$; essa característica,

\footnotetext{
${ }^{43}$ SAMUEL Ross LutTRell. Bias challenge in international commercial arbitration: the need for a 'real danger' test. The Hague: Kluwer Law International, 2009, p. 20.

${ }^{44}$ PIERRE LALIVE. On neutrality of the arbitrator and of the place for arbitration, in CLAUDE REYMOND; EUGÈNE BUCHER (Ed.). Swiss essays on international arbitration. Zurich: Schulthess Polygraphischer Verlag, 1984, p. 23.

${ }^{45}$ M. SCOTT DONAHEY. The independence... op. cit., p. 32.

${ }^{46}$ TIBER VÁRADY; JOHN J. BARCELÓ III; ARTHUR T. VON MEHREN. International commercial arbitration: a transnational perspective. 3. ed. New York: West Publishing, 2006, p. 265.
}

${ }^{47}$ Nesse sentido, "[m]ore than a national lawyer, someone who is internationally-minded, trained in comparative law and inclined to adapt to a comparative and truly 'international outlook'. In this way, he will really be neutral in relation to the legal systems and methods, whether procedural or substantive, of both parties - systems and methods which, whatever may be the law chosen to govern the subject-matter in dispute, are bound to influence to some extent the parties' attitudes and presentations, consciously or not, as arbitration practice frequently reveals". PIERRE LALIVE. On neutrality... op. cit., p. 23. É por essa razão que os regulamentos de algumas instituições arbitrais, tal como o da CCI (art. 13.5), estabelecem que em processos nos quais haja partes de diferentes nacionalidades, o árbitro presidente ou o árbitro único não deve compartilhar a nacionalidade de nenhuma delas.

${ }^{48}$ ILHYUNG LEE. Practice and predicament: the nationality of the international arbitration (whit survey results), in Fordham international law journal, v. 31, n. 3, 2008, p. 604. Em crítica a essa percepção, JAN PAULSSON. Moral hazard in international dispute resolution, p. 10; disponível no endereço eletrônico http://www.arbitration-icca.org/media/0/12773749999020/paulsson_moral_hazard.pdf; $\quad$ consulta em 21.02.2014. 
desejável nos coárbitros, não se coadunaria com o papel a ser desempenhado pelo árbitro presidente $^{49}$.

Existe, ainda, uma acepção do termo "neutralidade" derivada da prática arbitral norteamericana, segundo a qual os árbitros não neutros (escolhidos pelas partes) possuiriam padrões de independência e imparcialidade diferentes do árbitro neutro (o presidente do painel), o que lhes possibilitaria, entre outras peculiaridades, ostentar predisposição à tese defendida pela parte que o indicou, servindo como seu representante no tribunal arbitral ${ }^{50}$ inclusive para discutir com ela, diretamente e sem a presença da outra parte ou do restante dos julgadores, a força dos seus argumentos perante o tribunal arbitral para facilitar eventual composição ${ }^{51}$.

A exemplo do que ocorre com a relação entre as noções gerais de independência e imparcialidade, a relação destas com a noção geral de neutralidade e sua importância para a arbitragem não são tradadas de modo claro e uniforme: há quem coloque a independência como o resultado da neutralidade e imparcialidade, que seriam seus pré-requisitos, de modo que a neutralidade seria a possibilidade do árbitro ser e manter-se totalmente equidistante em pensamento e ações durante todo o curso do processo, enquanto a imparcialidade envolveria o status do árbitro a ser realmente testado no contexto das concretas relações existentes entre o árbitro e cada parte ${ }^{52}$; e há quem, em sentido oposto, sugira ser a neutralidade a mais proeminente característica do árbitro, à frente da imparcialidade e independência ${ }^{53}$. Outro entendimento, por fim, nega autonomia à

\footnotetext{
${ }^{49}$ Nesse sentido: "the usual practice in international commercial arbitration is to appoint a sole arbitrator (or a presiding arbitrator) of a different nationality from that of the parties to the dispute". ALAN REDFERN; MARTIN HunTeR; Nigel Blackaby; Constantine PARTASIDES. Redfern and Hunter on international commercial arbitration, 5. ed. New York: Oxford University, 2009, pp. 261-262.

${ }^{50}$ SETH H. LIEBERMAN. Something's rotten in the state of party-appointed arbitration: healing ADR's black eye that is "nonneutral neutrals", in Cardozo journal of conflict resolution, v. 5, 2004, pp. 224-225. No entanto, o autor demonstra que os diferentes Circuitos norte-americanos - e os próprios profissionais que atuam como árbitros - não têm entedimento unívoco sobre o comportamento esperado do "non-neutral" no que diz respeito à sua vinculação à tese da parte que o nomeou, às comunicações com a parte e quanto ao alcance do dever de revelação.

${ }^{51}$ Olga K. BYRNE. A new code of ethics for commercial arbitrators: the neutrality of party-appointed arbitrators on a tripartite panel, in Fordham urban law journal, v. 30, 2003, pp. 1842-1843.

${ }^{52}$ GIORGIO BERNINI. Report on neutrality, impartiality, and independence, in The arbitral process and the independence of arbitrators. Paris: ICC Publishing, 1991, p. 31.

${ }^{53}$ Pierre Lalive. On neutrality... op. cit., p. 24.
} 
neutralidade, enquadrando seu conteúdo nas noções de imparcialidade ou de independência ${ }^{54}$.

O apoio na legislação e doutrina dedicadas ao tema da imparcialidade do árbitro nada mais confere senão uma noção genérica do seu conteúdo em comparação a noções também genéricas de independência e de neutralidade, que não são operativas para a solução dos casos concretos, visto não permitirem a identificação precisa da sua inter-relação e, por derivação, a extração de consequências jurídicas.

\subsubsection{Impossibilidade de identificação precisa dos conteúdos da imparcialidade, da independência, da neutralidade e da sua importância no caso concreto}

Mesmo que, com algum voluntarismo, fosse possível a superação das dificuldades para a conceituação e inter-relação entre imparcialidade, independência e neutralidade dos árbitros com o apoio em noções gerais - cuja aceitação, já se viu, não é pacífica - o que se veria, em um exame mais aprofundado, é que tais noções não possuem nível de detalhamento e especificidade para a efetiva operação em casos concretos.

A noção geral de imparcialidade como inclinação inadmissível do árbitro a ponto de ensejar prejulgamento não é operativa, pois, além de não trazer o método pelo qual terceiros poderiam mensurar objetivamente uma inclinação psíquica e subjetiva do árbitro $^{55}$, também não permite o traçado da linha divisória entre as crenças e pontos de vista (inalienáveis, visto que o árbitro também é uma pessoa inserida no mundo) aceitáveis do julgador e as crenças e pontos de vista que impediriam uma análise imparcial do litígio. Sem desenvolvimento e fora de premissas claras de análise, a noção de imparcialidade não é útil e não responde a questões que podem se suceder - e se sucedem na vida real - em escala progressiva de complexidade. Pergunta-se: deveria ser qualificado como imparcial o árbitro que é um especialista na matéria objeto do conflito, se já houvesse publicado estudo no qual revelasse sua posição, que seria a priori favorável a uma das partes, como por exemplo, uma visão pró-minoritários em conflitos societários? E se o árbitro, sem nada ter

\footnotetext{
${ }^{54}$ WiLliam W. PARK. Arbitrator integrity... op. cit., p. 637.

${ }^{55}$ Esse tema será tratado no capítulo 2.1.2 do presente estudo.
} 
escrito ou publicado, participasse de encontro acadêmico cujo tema fosse "sociedades e acionistas minoritários", organizado por um grupo de estudos patrocinado por companhias listadas na BOVESPA? E se, ao invés de meramente participar de evento, o árbitro fosse participante ativo de um grupo de estudos sobre essa matéria? E se fosse o coordenador desse grupo? E se, ao invés de grupo de estudos, o árbitro participasse de uma instituição de "defesa" dos acionistas minoritários? O que ocorreria se um acionista minoritário ou seu advogado, envolvidos no processo arbitral, também participassem de uma ou mais dessas atividades ${ }^{56}$ ?

Por sua vez, não parece correta a afirmação de que a independência seria de mais fácil identificação, pois diferentemente da imparcialidade, seria verificável objetivamente ${ }^{57}$. Se ela deriva da existência de um vínculo entre o árbitro e a parte (ou seu advogado), parece evidente que o grau de dependência irá variar de acordo com a natureza ou a estreiteza desse vínculo. Não basta, assim, identificar tal vínculo, tornando-se inescapável o exercício de um juízo de valor sobre o grau de dependência que ele cria. Não há dúvida de que o árbitro, ao ser titular de $50 \%$ das ações representativas do capital de uma sociedade que venha a ser parte em um procedimento arbitral, dela retirando o seu sustento, está intimamente ligado por laço de dependência. Mas, e se ao invés de 50\%, o árbitro fosse titular de uma dezena de ações de uma companhia com muitos milhões delas? E se, ao invés de ações, o árbitro fosse proprietário de quotas de um fundo que, entre outras companhias, também investisse naquela que figurava como parte no litígio? E se o árbitro fosse acionista do banco que gerisse tal fundo? Todas essas situações se alterariam se o árbitro houvesse entregado a administração do seu patrimônio a gestor profissional, a quem incumbiam as escolhas de investimento? Faria diferença se a aquisição das ações ou quotas tivesse ocorrido depois da instauração do procedimento arbitral? E se fosse antes, faria

\footnotetext{
${ }^{56}$ No que diz respeito à participação do árbitro e de uma parte em um mesmo colóquio (sem qualquer consideração quanto às orientações ideológicas do árbitro - o que afasta o caso do exemplo discutido), já foi decidido pela Corte de Cassação francesa que tal fato, ainda que não revelado, não enseja dúvida quanto à imparcialidade do árbitro. Cour de cassation, decisão de 04.07. 2012, in Revue de l'arbitrage, 2012, n 3, p. 682.

${ }^{57}$ Nesse sentido: "The concept is related to an objective measure in the sense that it is possible to determine what is the relationship between the arbitrator and the party in question". BRUNO MANZANARES BASTIDA. The independence and impartiality of arbitrators in International commercial arbitration, in Revista emercatoria, v. 6, 2007, p. 4.
} 
diferença se fossem três meses ou três anos? ${ }^{58}$ Outros exemplos sobre dependência: no Brasil, onde se sobressai a qualidade das universidades públicas, seria dependente do Estado o árbitro que fosse professor de uma dessas instituições, a ponto de não poder julgar causas que envolvessem empresas públicas ou de economia mista que a ele fossem vinculadas? Faria diferença o valor da remuneração que o árbitro recebesse da universidade pública? E se a universidade fosse federal, estaria o árbitro vetado a participar de processos arbitrais em que fosse parte uma empresa na qual o Banco Nacional de Desenvolvimento Econômico e Social (BNDES) houvesse investido ou da qual tivesse adquirido participação?

Em todos esses casos há um liame objetivo entre árbitro e parte, mas seria uma redução inaceitável apontar que todos eles caracterizam dependência - ou, ao menos, o mesmo grau de dependência - a ponto de impedir que o árbitro participe do julgamento da causa ${ }^{59}$ por violação da imparcialidade. Das duas, uma: ou qualquer liame (ainda que tênue) caracterizará a dependência, sendo que o seu grau pode ou não influenciar na imparcialidade; ou apenas o liame (ainda que tênue) que influenciar na imparcialidade caracterizará a dependência. Seja como for, a objetividade supostamente evidenciada pela noção geral demonstra ter pouca serventia para a operação de casos concretos.

Também a noção geral de neutralidade, que gira em torno da ausência de identidade nacional, cultural ou religiosa do árbitro com uma das partes, não é operativa. A despeito de a neutralidade aparentemente configurar elemento verificável objetivamente, a sua efetiva influência na decisão proferida em um procedimento arbitral não pode ser medida de modo concreto, indicando apenas uma possibilidade de que o árbitro venha a julgar

\footnotetext{
${ }^{58}$ Também demonstrando que a imparcialidade não se revela com a propalada objetividade, embora com outros exemplos, CHRISTOPHER KOCH. Standards and procedures for disqualifying arbitrators, in Journal of international arbitration, v. 20, n. 4, 2003, pp. 237-239.

${ }^{59}$ Nesse sentido: “An arbitrator who is impartial but not wholly independent may be qualified, while an independent arbitrator who is not impartial must be disqualified. In selecting party-appointed arbitrators in international arbitration, the absolutely inalienable and predominant standard should be impartiality". DOAK BISHOP; LUCY REED. Practical guidelines for interviewing, selecting and challenging party-appointed arbitrators in international commercial arbitration, in Arbitration international, v. 14, n. 4, 1998, p. 395.
} 
impropriamente ${ }^{60} \mathrm{e}$, nesse sentido, minando a confiança das partes no procedimento específico $^{61}$.

A noção geral de neutralidade, além de sofrer do mesmo problema que atinge a noção geral de dependência, qual seja, a necessidade de atribuição de graus para dita identidade nacional, cultural ou religiosa entre árbitro e parte, sofre também da ausência de um critério para que mesmo objetivamente tal identidade seja reconhecida.

O que seria identidade nacional? Ela envolveria o país de nascimento do árbitro, o país que lhe conferiu cidadania ou também o país de domicílio? Imagine-se o seguinte exemplo ${ }^{62}$ : um negócio entre uma indústria coreana e uma empresa japonesa, que distribui os produtos da primeira no mercado japonês, enseja conflito submetido a procedimento arbitral a ser decidido por árbitro único em Tóquio, segundo a lei coreana. Tomando-se neutralidade por mera nacionalidade, a conclusão é a de que tanto um árbitro coreano quanto um japonês não seriam neutros ${ }^{63}$. Mas o que aconteceria se o árbitro fosse norte-americano (sem origem japonesa ou coreana) que tivesse tido domicílio durante tempo considerável no Japão ou na Coreia ${ }^{64}$ ? E se apenas tivesse residido por curto período de tempo? E se o árbitro tivesse pais nacionais desses países, tivesse lá nascido e crescido, mas imigrado aos Estados Unidos, onde teria adquirido cidadania e renunciado à cidadania de origem ${ }^{65}$ ?

${ }^{60}$ Nesse sentido: "Neutrality is not synonymous with impartiality. Rather, it is an exterior sign or an indication of likely impartiality; neutrality is easier to recognize, and easier to translate into standards". TIBER VÁRAdy; JOHN J. BARCELÓ III; ARTHUR T. VON MEHREN. International commercial... op. cit., p. 265.

${ }^{61}$ Nesse sentido: Há um "greater degree of confidence... on all sides if there is no chance that one party will get a better hearing because of some cultural or national identification between the party and the arbitrator". TOBY LANDAU. Composition and establishment of the tribunal, in American review of international arbitration, v. 9, 1998, p. 73.

${ }^{62}$ Apresentado por ILHYUNG LEE. Practice... op. cit., pp. 620-621.

${ }^{63} \mathrm{O}$ autor da hipótese conduziu uma pesquisa entre advogados experientes em arbitragens internacionais que trabalham em Seul, na qual lhes foi perguntado se a nomeação de árbitro de nacionalidade japonesa no exemplo em questão os preocuparia (com três respostas possíveis: "não me preocuparia", "teria alguma preocupação" ou "iria me preocupar muito"), bem como se tais advogados iriam ou não impugnar o árbitro apontado. Dos dezenove advogados consultados, dois responderam ter alguma preocupação e dezessete responderam que se preocupariam muito; dezessete também responderam que impugnariam o árbitro, um respondeu que não impugnaria e outro não respondeu a essa pergunta. ILHYUNG LEE. Practice... op. cit., pp. 622-623.

${ }^{64}$ Dos dezenove advogados que responderam à pesquisa, três revelaram que o árbitro americano que tivesse vivido tempo considerável no Japão não os preocuparia, onze apontaram que teriam alguma preocupação e cinco responderam que se preocupariam muito. Doze advogados disseram que impugnariam o árbitro. ILHYUNG LEE. Practice... op. cit., p. 624.

${ }^{65}$ Dos dezenove advogados que responderam à pesquisa, nove indicaram alguma preocupação e dez afirmaram que ficariam muito preocupados. Dezesseis afirmaram que impugnariam o árbitro e dois 
Seria importante para a avaliação da neutralidade do árbitro o exame da sua auto-imagem como sendo um "japonês nos Estados Unidos", um "nipo-americano", um "americano de ascendência japonesa" ou simplesmente um "americano"? E se o árbitro tivesse nascido nos Estados Unidos, com ascendentes que emigraram do Japão já adultos ${ }^{66}$ ?

Ademais, ainda que a neutralidade, no sentido de ausência de identidade nacional não se fizesse presente no caso concreto (ou seja, o árbitro tivesse a mesma nacionalidade que uma das partes e diferente da outra), mas se isso fosse conhecido e aceito pelas partes, o árbitro estaria impedido de funcionar em determinada arbitragem? Ou a neutralidade apenas teria relevância se interferisse na imparcialidade?

Logo se vê que as noções gerais de independência e de neutralidade têm pouca autonomia e podem, com vantagens, ser reconduzidas ao conceito de imparcialidade, conforme a proposta deste estudo.

\subsection{Tentativas de padronização da imparcialidade do árbitro}

\subsubsection{As diversas técnicas de padronização}

Diferentes técnicas foram concebidas na tentativa de se superar as deficiências ensejadas pelas noções genéricas de imparcialidade e independência, e assim possibilitar a solução de casos concretos. Em geral, tais técnicas conferem mais concretude às ditas noções ao circunscreverem - com graus diferentes de especificidade e por meios diversos - as causas de recusa do árbitro ou da sua impugnação pelas partes. Delineando-se, portanto, as causas de recusa ou impugnação do árbitro, são também delineados padrões hábeis a orientar a solução de casos concretos.

informaram que não o fariam. Um advogado não respondeu à pergunta sobre a impugnação. ILHYUNG LEE. Practice... op. cit., pp. 624-625.

${ }^{66}$ Nessa versão, três advogados responderam que não teriam qualquer preocupação, dez indicaram que teriam alguma preocupação e seis informaram que se preocupariam muito. Quatorze advogados afirmaram que impugnariam o árbitro. ILHYUNG LEE. Practice... op. cit., p. 627. 
Essa especificação das causas de recusa e impugnação do árbitro pode ser realizada por direta tipificação legal ou, quando a lei estatal confere essa abertura, por tipificação nos regulamentos das instituições arbitrais. É possível, porém, que a lei não tipifique as causas de recusa e impugnação do árbitro, mas sim estabeleça critérios mais ou menos abertos que servem de balizas para a futura identificação dessas causas pelo intérprete. É possível, ainda - o que ocorre sobretudo nos países de tradição common law ${ }^{67}$ - que a lei não estabeleça critérios interpretativos para a recusa ou impugnação do árbitro, cabendo à jurisprudência o papel de estabelecer os padrões de orientação com a utilização de "testes" 68 derivados de casos concretos.

Tal como se verá, é comum a sobreposição das técnicas no mesmo ordenamento: ainda que a lei tipifique os casos de recusa ou impugnação do árbitro, aceitam-se também as hipóteses estabelecidas em regulamentos arbitrais ou identificadas pela jurisprudência mediante a concepção de critérios interpretativos. Não há, assim, a adoção exclusiva de uma técnica, mas sim a sobreposição delas, o que já permite o vislumbre da sua insuficiência quando isoladamente aplicadas.

\subsubsection{As técnicas de padronização na experiência da civil law}

\subsubsection{Equivalência entre causas de recusa ou impugnação do árbitro e do juiz}

A mais antiga técnica de padronização da imparcialidade do árbitro segue - por equivalência estabelecida em lei ou jurisprudencialmente - as regras disciplinadoras da imparcialidade do juiz estatal, sob a premissa de que o árbitro seria juiz de fato e de

\footnotetext{
${ }^{67}$ Não se pode desconhecer que o termo "common law" agrega experiências jurídicas comuns até certo ponto, a partir do qual se distinguem, conforme bem demonstra Guido Soares, ao comentar as diversas acepções do termo e ressaltar as diferentes experiências jurídicas seguidas pela Inglaterra e pelos Estados Unidos da América. GuIdo Fernando Silva SoARES. Common law: introdução ao direito dos EUA, 1. ed. (2a tir.), São Paulo: RT, 1999, pp. 32-47 e 58-64. A evolução das teorias a respeito da common law, apresentada para leitores não afeitos a essa tradição, é traçada por JULIO CÉSAR CUETO RÚA. El “common law”: su estructura normativa; su enseñanza. Buenos Aires: Abeledo-Perrot, 1997, pp. 19-87.

${ }^{68}$ Sobre os testes empregados pela jurisprudência para a análise da imparcialidade, vide capítulo 1.3.3 do presente estudo. Nos países de tradição commom law, a exceção relevante é a Austrália, que positivou o teste "real danger" a partir de 17 de junho de 2010, no seu International Arbitration Act, conforme aponta SAMUEl Ross LUTTRELl. Australia adopts the 'real danger' test for arbitrator bias, in Arbitration international, v. 26, n. 4, 2010, pp. 625-632.
} 
direito $^{69}$. Vários países optaram por essa orientação e a alteraram, tal como Alemanha, Bélgica e Espanha, ao passo que outros, tais como Argentina, Chile, Suíça ${ }^{70}$ ainda a mantêm.

Ao disciplinar as causas de recusa dos árbitros, o $§ 1032$ da lei processual alemã (“Zivilprozessordnung”), na sua redação original, fazia referência às causas de recusa dos juízes $^{71}$. A partir da reforma processual de 1998, entretanto, a Alemanha adotou a Lei Modelo UNCITRAL, alterando a redação do § 1036, II, ZPO, e estabeleceu a possibilidade de recusa do árbitro quando existirem circunstâncias que permitam levantar "dúvidas justificadas" sobre sua imparcialidade ou independência ${ }^{72}$.

Na Bélgica, sob a vigência do Code Judiciaire de 1967, os árbitros podiam ser recusados pelas mesmas causas que os juízes ${ }^{73}$, mas, por reforma legislativa de 1998, que visou harmonizar a legislação às práticas da arbitragem internacional ${ }^{74}$, a identificação entre causas de impugnação de árbitros e juízes foi rompida, passando o árbitro a poder ser recusado pela existência de circunstâncias que ensejassem dúvidas legítimas sobre sua imparcialidade ou independência ${ }^{75}$. Nova alteração, de junho de 2013 , refinou o texto

${ }^{69}$ ChIARA SPACCAPElo. L'imparzialità... op. cit., p. 262.

${ }^{70}$ Também aqui a equivalência entre os motivos de recusa e impugnação do árbitro e do juiz funciona para as arbitragens internas, conforme o art. 18 da Concordat sur l'arbitrage.

${ }^{71}$ Em tradução para o francês: “...la récusation est justifiée lorsqu'un motif existe de douter de l'impartialité du juge". PETER F. SCHLOSSER. L'impartialité e l'indépendance de l'arbitre en droit allemand, in JACQUES VAN COMPERNOLLE et al. (Ed.). L'impartialité du juge et de l'arbitre, Bruxelles: Bruylant, 2006, p. 301.

72 PhILIPP K. WAGNeR. Arbitration in Germany, in New York State Bar Association international law practicum, v. 23, 2010, p. 106. SAMUEL Ross LUTTRELl. Bias... op. cit., pp. 103-104.

${ }^{73} \mathrm{Na}$ língua original: "Les arbitres peuvent être récusés pour les mêmes causes que les juges". Disponível no endereço eletrônico http://www.ejustice.just.fgov.be/cgi_loi/arch_a.pl?chercher=t\&language=fr\&dt=CODE+JUDICIAIRE\&choi

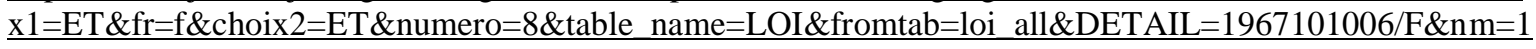
967101057\&sql=dt+contains++'CODE'\%2526+'JUDICIAIRE'and+actif+=+'Y'\&rech=13\&tri=dd+AS+RAN K+\&trier=promulgation\&cn=1967101006\&row id=1\&caller=archive\&la=F\&ver_arch=002; consulta em 21.02.2014.

${ }^{74}$ G. HORSMANS. La loi belge du 19 mai 1998 sur l'arbitrage, in Revue d'arbitrage, 1999, n. 3, p. 475. Também sobre o tema, GUY KEUTGEN. L'indépendance et l'impartialité de l'arbitre em droit belge, in JACQUES VAN COMPERNOLLE et al. (Ed.). L'impartialité... op. cit., p. 276.

${ }^{75} \mathrm{Na}$ língua original: “Art. 1690. 1. Les arbitres peuvent être récusés s'il existe des circonstances de nature à soulever des doutes légitimes sur leur impartialité ou leur indépendance”. Disponível no endereço eletrônico http://www.ejustice.just.fgov.be/cgi_loi/loi_a.pl?language=fr\&dt=LOI\&chercher=c\&fr=f\&numero=13\&text $1=$ code+judiciaire \&table name=loi\&fromtab=loi_all\&imgcn.x=54\&DETAIL=1998051945/F\&nm=1998009 527\&imgcn.y=6\&sql=dt+contains++'LOI'+and+(+tit+contains+proximity+40+characters+(+'code'\%2526+'ju diciaire')+++)and+actif+=+'Y'\&rech=330\&tri=so+AS+RANK+\&cn=1998051945\&row id=1\&caller=image 
relativamente à matéria, passando-o de afirmativo para negativo com vistas a tornar mais restritivas as causas de recusa do árbitro ${ }^{76}$.

O art. 23 da antiga Ley Sobre Arbitraje de Derecho Privado espanhola de 1953 determinava que não podia ser nomeado árbitro a pessoa que tivesse com as partes ou com a controvérsia alguma das relações que estabelecessem a possibilidade de abstención (equivalente ao impedimento, declarável de ofício) ou recusación (equivalente à suspeição, dependente de alegação das partes) de um juiz, disciplinadas no artigo 188 e seguintes da Ley de Enjuiciamiento Civil então vigente ${ }^{77}$. Com alguma evolução - pois previsto o dever de revelação, inexistente no diploma anterior - a orientação foi mantida na Ley de Arbitraje de 1988 (Ley 36/1988) ${ }^{78}$ - que serviu de inspiração para a LA ${ }^{79}$. No entanto, a Ley de Arbitraje de 2003 (Ley 60/2003) alterou significativamente a orientação, apartando os casos de recusa ou impugnação de árbitro e de juiz, dado o entendimento de que os últimos não eram adequados em matéria de arbitragem por não cobrirem as hipóteses

_a1\&la=F\&pdf_page=1\&pdf_file=http://www.ejustice.just.fgov.be/mopdf/1998/08/07_1.pdf; consulta em 21.02 .2014

${ }^{76}$ Conforme art. 1686, $\S 2^{\circ}$, na língua original: "Un arbitre ne peut être récusé que s'il existe des circonstances de nature à soulever des doutes légitimes sur son indépendance ou son impartialité". Disponível no endereço eletrônico http://www.ejustice.just.fgov.be/cgi_loi/loi_a.pl?language=fr\&dt=LOI\&chercher=t\&choix $1=E T \& f r=f \& c h o i$ $\mathrm{x} 2=\mathrm{ET} \&$ numero $=1 \&$ text $1=$ code + judiciaire\&table name $=$ LOI\&text $2=$ arbitrage\&fromtab $=$ loi_all \&imgcn. $\mathrm{x}=4$ 4\&DETAIL $=2013062403 / \mathrm{F} \& \mathrm{~nm}=2013009310 \& \mathrm{img} \mathrm{cn} . \mathrm{y}=10 \& \mathrm{sql}=\mathrm{dt}+$ contains $++{ }^{\prime} \mathrm{LOI}+\mathrm{and}+((+\mathrm{tit}+$ contains + proximity+40+characters+(+'code'\%2526+'judiciaire')++AND+text+CONTAINS+++(+'arbitrage')++)+or+(+ text+contains+proximity+40+characters+(+'code' $\% 2526+$ 'judiciaire')++AND+text+CONTAINS+++(+'arbitr age')++))and+actif +=+'Y'\&rech=90\&tri=dd+AS+RANK+\&trier=promulgation\&cn=2013062403\&row id=1 \&caller=image a1\&la=F\&pdf_page=3\&pdf file=http://www.ejustice.just.fgov.be/mopdf/2013/06/28 2.pdf; consulta em 21.02.2014. Comparar com a transcrição da nota de rodapé anterior.

77 As causas de recusa ou impugnação do juiz, aplicáveis ao árbitro, são enumeradas por José M. CHILLón MEDINA; José F. MERINO MERCHÁN. Tratado de arbitraje privado interno e internacional. Madrid: Editorial Civitas, 1978, p. 182: "1. El parentesco de consanguinidad o afinidad, dentro del cuarto grado civil, con cualquiera de los litigantes. 2. El mismo parentesco, dentro del segundo grado, con el Letrado de alguna de las partes que intervengan en el pleito. Esto se entenderá sin perjuicio de hacer cumplir la prohibición que tiene los Abogados para encargarse en la defensa de asuntos en que deben conocer como Jueces sus parientes dentro de dicho grado. 3. Estar o haber sido denunciado por alguna de las partes como autor, cómplice o encubridor de un delito, o como autor de una falta. 4. Haber sido defensor de alguna de las partes, emitido dictamen sobre el pleito como Letrado, o intervenido en él como Fiscal, perito o testigo. 5. Ser o haber sido tutor o curador para bienes, o haber estado bajo la tutela o curaduría de alguno que sea parte en el pleito. 6. Ser o haber sido denunciador o acusador privado del que recusa. 7. Tener pleito pendiente con el recusante. 8. Tener interés directo o indirecto en el pleito o en otro semejante. 9. Amistad intima. 10. Enemistad manifiesta."

78 Disponível no endereço eletrônico http://noticias.juridicas.com/base datos/Derogadas/r1-1361988.t3.html\#a18; consulta em 21.02.2014.

${ }^{79}$ Assim afirma um dos elaboradores do anteprojeto. CARLOS Alberto CARMONA. Arbitragem... op. cit., p. 11. 
particulares ao método ${ }^{80}$. Assim, o direito espanhol, pelo art. 12.2 da Ley 60/2003, originalmente voltado à identificação entre causas de imparcialidade de juiz e de árbitro, passou a adotar a padronização aberta, pela qual a recusa ou impugnação do árbitro deve se fundamentar em "dúvidas justificadas a respeito da sua imparcialidade ou independência" ${ }^{\prime 81}$.

No Chile, a concepção de que o árbitro pertence à "ordem judicial" levou à equivalência entre os motivos de recusa ou impugnação do árbitro e do juiz para as arbitragens internas, consoante o art. 243 do Código Orgánico de Tribunales (Ley $\left.n^{o} 7421 / 1943\right)^{82}$, orientação que é criticada por não compreender que o desempenho profissional do árbitro necessariamente um advogado para as arbitragens de direito - envolve situações e relações profissionais não aplicáveis aos juízes, razão pela qual o dispositivo deveria ser interpretado extensivamente ${ }^{83}$. Já para as arbitragens comerciais internacionais, reguladas pela Ley $n^{\circ}$ 1997, de 2004, há outra solução: seu art. 12 prevê que o árbitro pode ser recusado ou impugnado se não ostentar as qualidades requeridas pelas partes ou se estiverem presentes circunstâncias que determinem "dúvida legítima" sobre sua imparcialidade ou independência ${ }^{84}$.

Nos exemplos tratados, o que se vê é a paulatina perda da identidade legal entre as causas de impugnação de juízes e árbitros, visto que, embora ambos os profissionais decidam os conflitos que lhe sejam submetidos, estão sujeitos a diferentes contextos profissionais para o exercício da sua função, sendo o principal deles o fato de os juízes não serem escolhidos pelas partes, pertencendo a um Poder estatal, ao passo que os árbitros, comumente mais envolvidos com o mercado, são escolhidos pelas partes. Por conta disso, inúmeras

\footnotetext{
${ }^{80}$ FAUSTINO CORDÓN MORENO. El arbitraje de derecho privado. Cizur Menor: Editorial Aranzadi, 2005, p. 162.

${ }^{81}$ Disponível no endereço eletrônico http://www.boe.es/buscar/doc.php?id=BOE-A-2003-23646; consulta em 21.02.2014.

${ }^{82}$ AlejANDRO ROMERO SEgUel. La independencia e la imparcialidad en la justicia arbitral, in Revista chilena de derecho, v. 28, n. 3, 2001, p. 510. Optou-se por não se enumerar os casos de recusación do juiz no direito chileno, dado o seu grande número. Ditos casos podem ser consultados na legislação disponível no endereço eletrônico http://www.nuestroabogado.cl/organicotribunales.htm; consulta em 21.02.2014.

${ }^{83}$ AleJANDRO ROMERO SEGUEL. La independencia... op. cit., pp. 519-520 e 531.

${ }^{84}$ Sobre a arbitragem comercial internacional chilena, vide CRISTIAN CONEJERO ROOS. The new chilean arbitration law and the influence of the model law, in Journal of international arbitration, v. 22, n. 2, 2005, pp. 149-162.
} 
situações fáticas que seriam inconcebíveis para os juízes podem ocorrer em relação aos árbitros, tornando o método da identidade legal de causas de impugnação superado.

\subsubsection{Tipificação legal dos casos de recusa ou impugnação do árbitro}

Outra técnica, agora menos comum, de padronização da imparcialidade do árbitro é a tipificação legal mediante o estabelecimento de causas definidas e exclusivas para sua recusa ou impugnação.

Dada a sua tradição legalista ${ }^{85}$, a China é um dos poucos exemplos nessa área. A legislação arbitral do país, no art. 34, prevê quatro circunstâncias em que a recusa ou impugnação do árbitro pode ocorrer: (i) o árbitro ser parte no processo arbitral ou ser familiar das partes ou de seus advogados; (ii) o árbitro possuir interesse pessoal no caso; (iii) o árbitro conhecer ou possuir outras relações com uma das partes ou com qualquer dos advogados envolvidos no caso, que possam prejudicar a prolação de uma sentença justa e imparcial; e (iv) o árbitro ter se encontrado em particular com qualquer das partes ou seus respectivos advogados, ter aceitado presentes deles ou ter participado de banquetes que eles tenham $\operatorname{promovidos}^{86}$.

É possível notar que, a despeito da tipificação, a regra legal utiliza termo de significado consideravelmente aberto, como "interesse pessoal”, e não define ou circunscreve quais os tipos de relações entre árbitro e partes (ou seus advogados) que podem ser considerados "prejudiciais" à prolação de uma sentença imparcial, o que fica a cargo do intérprete na análise do caso concreto. Mesmo com essa abertura, a tipificação foi considerada insuficiente e a prática da arbitragem na China reconheceu outras circunstâncias que consistem ou em alargamento das hipóteses previstas na lei (tal como a discussão prévia do caso entre árbitro e partes ou seus advogados) ou em hipóteses totalmente novas (tal como

\footnotetext{
${ }^{85}$ Sobre a tradição legalista chinesa e suas origens filosófica e sociológica, bem como sua comparação com as tradições ocidentais, vide JIALUE LI. China, a sui generis case for the western rule-of-law model, in Georgetown journal of international law, v. 41, 2010, pp. 711-748.

${ }^{86}$ Arbitration Law of the People's Republic of China, disponível em inglês no endereço eletrônico http://en.chinacourt.org/public/detail.php?id=101; consulta em 21.02.2014.
} 
o árbitro possuir o mesmo empregador que uma das partes ou seus advogados) para a recusa ou impugnação de árbitro ${ }^{87}$.

As causas de recusa ou impugnação na lei de arbitragem chinesa não configuram, portanto, tipificação fechada, conclusão que se confirma quando examinado o Regulamento de Arbitragem da China International Economic and Trade Arbitration Commission (CIETAC), mais antiga e maior instituição administradora de processos arbitrais na China $^{88}$, que possui regra aberta - e efetivamente aplicada no âmbito da instituição - a respeito da imparcialidade do árbitro ${ }^{89}$. Referida regra, constante do art. 29 do Regulamento, determina que o árbitro informe quaisquer fatos ou circunstâncias que possam levantar "dúvidas justificadas" sobre a sua imparcialidade ou independência, inclusive no curso do processo arbitral. Com base nessa informação, as partes podem impugnar o árbitro e, se essa impugnação for contestada pela outra parte, caberá ao Presidente da CIETAC decidir o incidente, conforme art. 30 do Regulamento ${ }^{90}$.

Outro exemplo de tipificação legal, mais atenuada que o modelo chinês, vem da Suécia, que adota na prática uma técnica mista. Primeiramente, a Section 8 do Swedish Arbitration Act determina, na alínea 1, que o árbitro deve ser imparcial, sendo que a alínea 2 prevê que as partes podem requerer o afastamento do árbitro se existir qualquer circunstância que possa diminuir a confiança na sua imparcialidade, especificando quatro hipóteses: $(i)$ o árbitro ou uma pessoa próxima a ele figurar como parte no processo arbitral e poder esperar benefício ou prejuízo digno de relevância com a decisão do litígio; (ii) o árbitro ou pessoa próxima a ele ser diretor ou representante de pessoa jurídica que figura como parte e poder esperar benefício ou prejuízo digno de relevância com a decisão do litígio; (iii) o árbitro ter exercido previamente algum papel na disputa, como expert ou qualquer outro,

${ }^{87}$ JINGZHOU TAO. Arbitration law and practice in China. 2. ed. Netherlands: Kluwer Law International, 2008, pp. 131-132.

${ }^{88}$ Referências e estatísticas podem ser obtidas no endereço eletrônico http://www.cietac.org/index.cms; consulta em 21.02.2014.

${ }^{89}$ Joseph T. MCLAughlin; KATHLEen M. SCANLON; CATHERINE X. PAN. Planning for commercial dispute resolution in mainland China, in The american review of international arbitration, v. 16, 2005, p. 147. Sobre a favorável impressão geral de imparcialidade nas arbitragens administradas pela CIETAC, vide RANDALL PEERENBOOM; XIN He. Dispute resolution in China: patterns, causes and prognosis, in East Asian Law Review, v. 4, 2009, p. 29; para as críticas às falhas do órgão, vide MICHAEL I. KAPLAN. Solving the pitfalls of impartiality when arbitrating in China: how the lessons of the Soviet Union and Iran can provide solutions to western parties arbitrating in China, in Penn State law review, v. 110, 2005-2006, pp. 785-788.

90 CIETAC Arbitration Rules. Disponíveis em inglês no endereço eletrônico http://cn.cietac.org/rules/rules.pdf; consulta em 21.02.2014. 
ou ter auxiliado uma parte na preparação ou condução do caso; e (iv) o árbitro ter recebido ou requerido compensação sem o consentimento de ambas as partes no curso do processo $\operatorname{arbitral}^{91}$.

A despeito do que diz a lei, a Suprema Corte sueca ("Högsta domstolen") declarou em três ocasiões que a tipificação legal é exemplificativa, e não taxativa. Mais: as decisões fizeram o confronto das situações nos casos concretos com as hipóteses previstas nas IBA Guidelines $^{92}$, com referência expressa a esse texto. No primeiro caso, Anders Jilkén v. Ericsson $A B^{93}$, o presidente do tribunal arbitral foi afastado porque funcionava como consultor do escritório de advocacia que representava, na arbitragem, uma das partes (o grupo Ericsson). Na qualidade de consultor, o árbitro em questão possuía sala e tinha acesso a outros setores do escritório, chegando mesmo a prestar orientação jurídica ao grupo, embora ele não fosse seu cliente direto. Seu trabalho de consultor representava vinte por cento da sua remuneração total como profissional.

No segundo caso, Korsnäs v. AB Fortum Värme ${ }^{94}$, a Suprema Corte sueca considerou, também à luz das IBA Guidelines, que não deveria ser afastado o árbitro que, em um período de três anos, havia sido indicado duas vezes pelo mesmo escritório de advocacia para diferentes arbitragens. As duas indicações foram em número inferior às quatro previstas nas IBA Guidelines para gerar dúvidas quanto à imparcialidade do árbitro. Ademais, a grande parcela de indicações do árbitro no período adveio de outros escritórios de advocacia.

A decisão de um terceiro caso, $K P M G A B$ v. ProfilGruppen $A B$, proferida pela Corte de Recursos de Svea (“Svea hovrätt”), também fez expressa referência ao caráter meramente

91 The Swedish Arbitration Act (SFS 1999:116), no idioma original e em inglês, disponível no endereço eletrônico http://www.sccinstitute.com/?id=23746; consulta em 21.02.2014.

92 Vide capítulo 1.3.4 do presente estudo.

${ }^{93}$ Anders Jilkén v. Ericsson AB, julgado em 19 de novembro de 2007, caso T 2448-06. Tradução não oficial da decisão para o inglês disponível no endereço eletrônico http://www.arbitration.sccinstitute.com/files/1083436/T2448-06_en\%20English.pdf; consulta em 21.02.2014.

${ }^{94}$ Korsnäs v. AB Fortum Värme samägt med Stockholms stad, julgado em 9 de junho de 2010, caso T 15609. Decisão no original em sueco disponível no endereço http://www.hogstadomstolen.se/Domstolar/hogstadomstolen/Avgoranden/2010/2010-06-09\%20T\%2015609\%20dom.pdf; consulta em 21.02.2014. Sobre a decisão, com comentários em inglês, vide KAR-EIK DANIELSSON; BJÖRN TUDE. Sweden: two different arbitration cases, disponível no endereço eletrônico http://www.iflr.com/Article/2176818/Sweden-Two-different-arbitration-cases.html; consulta em 21.02.2014. 
exemplificativo da tipificação constante do Swedish Arbitration Act, resultando na anulação de sentença arbitral à luz de circunstâncias que implicaram, segundo o julgamento estatal, a diminuição da confiança na imparcialidade de um árbitro. No caso em questão, o árbitro indicado por uma das partes (KPMG) era sócio sênior da filial de um escritório de advocacia que passou a patrocinar, após a prolação da sentença arbitral e contra a própria KPMG, um litígio de várias centenas de milhões de euros. Foi provado que o escritório de advocacia do árbitro foi consultado no curso da arbitragem sobre a possibilidade de patrocínio desse litígio, aceitando-o antes da conclusão da arbitragem. A sentença na arbitragem foi proferida em 22 de dezembro de 2010 e a KPMG foi registrada como contraparte do cliente do escritório em 23 de dezembro de 2010, sendo que, por conta disso, a Corte de Recursos entendeu que o árbitro sabia ou deveria saber que seu escritório contratou o patrocínio de litígio contra uma das partes no curso de arbitragem, o que minaria a confiança das partes em sua imparcialidade ${ }^{95}$.

A experiência estrangeira demonstra que o estabelecimento do conceito de imparcialidade do árbitro com base na tipificação das causas que ensejariam a sua impugnação é impraticável, na medida em que não permite aplicação ou adaptação às inúmeras situações em que a postura ou as relações do árbitro com as partes, com terceiros ou com o litígio seja criticável ou gere dúvidas quanto ao favorecimento de uma parte, mas que não esteja compreendida nas causas legais de impugnação.

\subsubsection{Cláusula geral relativa à imparcialidade do árbitro}

No extremo oposto das legislações que buscaram definir com numerus clausus as causas de recusa ou impugnação dos árbitros, há outras que vinculam a imparcialidade dos julgadores à existência de dúvida aos olhos das partes (ou de terceiro isento) a esse respeito, estabelecendo uma "cláusula geral" ". Outras legislações, a exemplo da brasileira,

\footnotetext{
${ }^{95}$ KPMG AB v ProfilGruppen AB, julgado em 27 de setembro de 2011, caso T 1085-11. Tradução não oficial da decisão para o inglês disponível no endereço eletrônico http://www.jpinfonet.se/files/1023796/T\%201085-11_eng.pdf; consulta em 21.02.2014.

${ }^{96}$ Sobre o tema das cláusulas gerais, vide JUDITH MARTINS-COSTA. O direito privado como um 'sistema em construção': as cláusulas gerais no Projeto do Código Civil Brasileiro, in Revista de informação legislativa, n. 139, 1998, pp. 5-22. O tema será retomado no capítulo seguinte do presente estudo.
} 
apenas se utilizam do termo "imparcialidade" sem maiores indicações do seu conteúdo. Tal como já adiantado no presente capítulo ${ }^{97}$, essa é a orientação para a qual se inclinaram diversos países que, entre outras soluções, adotaram em larga medida a Lei Modelo UNCITRAL sobre Arbitragem Comercial Internacional de $1985^{98}$, que prevê a possibilidade de recusa ou impugnação do árbitro sempre que as circunstâncias derem ensejo a dúvidas justificadas sobre sua parcialidade ou independência.

\subsubsection{4. $\quad$ Um caso particular: a evolução das técnicas na França}

Em razão da sua evolução e da diversidade de técnicas que acolheu, o modelo francês de tratamento da imparcialidade é digno de nota.

Originalmente, diante da inexistência de uma regra específica a respeito dos motivos de recusa ou impugnação do árbitro, a orientação inicial da Corte de Cassação ("Cour de Cassation") francesa era estender ao árbitro os mesmos motivos aplicáveis para o juiz togado, previstos no art. 378 do antigo Code de Procédure Civile ${ }^{99}$. O sistema, no entanto, era considerado inadequado, pois o Judiciário francês considerava a imparcialidade ${ }^{100}$ do árbitro com menor rigor que a do juiz ${ }^{101}$.

Essa primeira orientação permaneceu com o advento do novo Code de Procédure Civile ${ }^{102}$. Segundo uma interpretação tradicional na doutrina e jurisprudência, ao árbitro seriam

\footnotetext{
${ }^{97}$ Item 1.3.2.1. Vide, também, item 1.3.3 deste estudo.

${ }^{98}$ A versão original da Lei Modelo, bem como a versão revista em 2006 podem ser obtidas no endereço eletrônico http://www.uncitral.org/uncitral/en/uncitral_texts/arbitration/1985Model_arbitration.html; consulta em 21.02.2014.

99 Assim afirma MARC HENRY. Le devoir d'indépendance de l'arbitre, Paris: LGDJ, 2001, p. 46.

$100 \mathrm{Na}$ doutrina e jurisprudência francesas, o termo impartialité é menos recorrente que o termo indépendance, que tem conotação bem mais ampla, usada para caracterizar até mesmo a orientação subjetiva do árbitro, como se vê na expressão "indépendance d'esprit". Em ampla análise do termo indépendance (sob as noções funcional, espiritual e dialética) para embasar a escolha pela não utilização do termo impartialité, vide THOMAS Clay. L'arbitre... op. cit., pp. 234-252. Para preservar a coerência terminológica do presente estudo, o termo "indépendance" utilizado na doutrina francesa será traduzido como "imparcialidade".

${ }^{101}$ MATTHIEU DE BoISSÉSON. Le droit français de l'arbitrage interne et international. Paris: Joly, 1990, p. 22. Aponta o autor que a interpretação contribuía para ensejar uma opinião geral desfavorável à arbitragem, vista sempre com olhos suspeitos.

102 Texto até 2007 denominado “Noveau Code de Procédure Civile”. Vide nota de rodapé no 32.
} 
aplicáveis os mesmos motivos de afastamento do juiz, previstos no art. 341 do Code de Procédure Civile, causas que eram taxativas e assim deviam ser entendidas tanto para o juiz quanto para o árbitro ${ }^{103}$. Isso se justificava tanto porque o árbitro teria o mesmo papel que o juiz, o que demandaria a identificação das causas de recusa ou impugnação, quanto pela exigência de segurança na arbitragem ${ }^{104}$.

A alteração da lei francesa, primeiramente relativa à arbitragem interna com o Decret $n$. 80-354, de 1980, e posteriormente também à arbitragem internacional com o Decret $n$. 81500, de 1981 - este último a revogar a quase totalidade do anterior e incluir o livro IV do Code de Procédure Civile, dedicado à arbitragem - ensejou uma forte mudança de rumo. Por essa alteração, o legislador francês, apesar de não ter feito referência expressa à independência ou imparcialidade do árbitro, referendou-as legislativamente de modo indireto, por determinar, no segundo parágrafo do art. 1.452, que o árbitro, ao aceitar o encargo, informasse às partes sobre qualquer motivo que pudessse dar causa à sua recusa. Em paralelo, o art. 1.463 do mesmo diploma, ao mencionar a recusa ou a abstenção do árbitro, abria caminho para que as partes motivadamente a requeressem.

Baseada na então nova redação legal, a Corte de Apelação (“Cour d'Appel”) de Paris iniciou nova orientação jurisprudencial, que culminou no reconhecimento de que a imparcialidade do árbitro é da essência da sua função jurisdicional e que as causas de recusa ou impugnação não se limitariam àquelas estabelecidas para os juízes. Ao contrário, as causas de impugnação seriam quaisquer hábeis a evidenciar a existência de ligações materiais ou intelectuais, caracterizando uma provável situação de influência no julgamento do árbitro e um risco de prejulgamento com relação a uma das partes na arbitragem $^{105}$. Com tal afirmação, foi superado o limite que havia circunscrito as hipóteses de recusa do árbitro àquelas do art. 341 do Code de Procédure Civile, tal como reconheceu

\footnotetext{
${ }^{103}$ Sobre o tema, MARC HENRY. Le devoir.... op. cit., pp. 296-299.

104 JEAN ROBERT. L'arbitrage, droit interne, droit international privé. 5. ed. Paris: Dalloz, 1983, p. 123.

${ }^{105}$ No original: "les circonstances invoquées pour contester cette indépendance doivent caractériser, par l'existence de liens matériels ou intellectuels, une situation de nature à affecter le jugement de l'arbitre en constituant un risque certain de prévention à l'égard de l'une des parties à l'arbitrage". Cour d'Appel de Paris, decisão de 23.03.1995, in Revue de l'arbitrage, 1996, n. 3, p. 446.
} 
a doutrina majoritária ${ }^{106}$, que considerava incongruente o transporte, para o árbitro, da regra concebida para o juiz.

Posteriormente, a Corte de Cassação passou a considerar que o art. 341 do Code de Procédure Civile, que previa apenas oito casos de recusa, não exauria sequer a exigência de imparcialidade requerida do juiz estatal ${ }^{107}$. Com isso, a prática francesa, originalmente apegada a numerus clausus, passou a operar mediante uma noção mais ampla de imparcialidade.

A ênfase dada pela lei para o dever de revelação do árbitro e a ausência de referência expressa à imparcialidade aparentemente influenciaram os tribunais franceses a considerar a violação do primeiro como causa do segundo. Como exemplo, pode ser citado o caso Somoclest vs. DV Construction ${ }^{108}$, no qual a Corte de Cassação estabeleceu que a nomeação sistemática de árbitro por sociedades de um mesmo grupo pode provocar dúvidas justificáveis quanto à sua imparcialidade aos olhos das partes, e deve ser absolutamente revelada. No caso em questão, o árbitro indicado pela Somoclest havia atuado por indicação das sociedades do grupo em outros cinquenta e um processos. Outra decisão da mesma corte anulou sentença proferida por árbitro que, ao aceitar o encargo, revelou apenas ter sido indicado várias vezes por uma das partes (sem, no entanto, especificar quantas). Na ação de anulação, soube-se que o número de indicações totalizava trinta e quatro, razão pela qual foi acatada a tese de que a frequência e a regularidade em longo período da relação entre o árbitro e a parte caracterizaria a existência de "affaires current" entre ambos, que deveria ao menos ter sido revelado para que a parte que desconhecia os fatos pudesse exercer o seu direito à impugnação do árbitro no curso do procedimento $^{109}$.

\footnotetext{
${ }^{106}$ Assim anota MARC HENRY. Le obligations d'indépendance et d'information de l'arbitre à la lumière de la jurisprudence récente, in Revue de l'arbitrage, 1999, n. 2, p. 201. No mesmo sentido, PHILLIPE FOUCHARD. Le statut de l'arbitre dans la jurisprudence française, in Revue de l'arbitrage, 1996, n. 3, p. 349.

${ }^{107}$ Cour de Cassation, decisão de 28.04.1998, in Revue trimestrielle de droit civil, n. 3, 1998, pp. 744-746.

${ }^{108}$ Cour de Cassation, decisão $\mathrm{n}^{\circ}$ 693, de 20.10 .2010 (09-68.997), disponível no endereço eletrônico http://www.courdecassation.fr/jurisprudence_2/premiere chambre civile 568/962_20 17860.html; consulta em 21.02.2014.

${ }^{109}$ No original: "Qu'en statuant ainsi, alors que le caractère systématique de la désignation d'une personne donnée par les sociétés d'un même groupe, sa fréquence et sa régularité sur une longue période, dans des contrats comparables, ont créé les conditions d'un courant d'affaires entre cette personne et les sociétés du groupe parties à la procédure de sorte que l'arbitre était tenu de révéler l'intégralité de cette situation à l'autre partie à l'effet de la mettre en mesure d'exercer son droit de récusation, la cour d'appel a violé les textes susvisés". Cour de Cassation, decisão n 692, de 20.10.2010 (09-68.131). Decisão disponível no
} 
O papel fundamental da jurisprudência na interpretação das causas de recusa ou impugnação do árbitro não se modificou nem mesmo com o advento do Décret 2011-48, de 2011, que alterou diversos dispositivos referentes à arbitragem do Code de Procédure Civile, entre eles, o art. 1456, que passou a prever expressamente que o árbitro, antes de aceitar sua missão, deve revelar todas as circunstâncias capazes de afetar sua independência ou sua imparcialidade ${ }^{110}$. As cortes estatais continuaram no seu papel de interpretação do texto e trataram, com profundidade, não mais dos reflexos da relação entre partes e árbitros fora da arbitragem para a imparcialidade, mas sim da relação entre o advogado (ou de seu escritório) com o árbitro e as consequências da não revelação pelo árbitro $^{111}$.

A reforma da lei francesa, contudo, não cuidou com propriedade do método de controle da imparcialidade do árbitro após a prolação da sentença arbitral, ao não estabelecer a falta de imparcialidade do árbitro como causa direta para anulação da sentença arbitral. Assim, é preciso encaixar a ocorrência em alguns dos incisos do novo art. 1520 do Code de Procédure Civile, sendo que alguns doutrinadores entendem que tal violação incidiria na previsão do inciso 2 (“constituição irregular do tribunal arbitral”) e que não abarcaria, em tese, as causas de perda da imparcialidade por fato posterior à dita constituição, enquanto outros acomodam o fato no inciso 5 ("violação da ordem pública internacional"), ou ainda, encaixam na previsão do inciso 3 (“desrespeito do árbitro quanto à sua missão”), que reclama uma distância razoável e equiparada do árbitro em relação às partes ${ }^{112}$.

O atual modelo de padronização da imparcialidade do árbitro adotado na França, baseado em noção genérica, ao mesmo tempo em que permite a flexibilidade e aproveitamento do

http://www.courdecassation.fr/jurisprudence_2/premiere_chambre_civile_568/962_20_17860.html; consulta em 21.02.2014.

110 Code Procédure Civile, disponível no endereço eletrônico http://www.legifrance.gouv.fr/affichCode.do;jsessionid=AFF74D5E43A870DC86EC846458FDDA6D.tpdjo $\underline{07 \mathrm{v} \text { 3? idSectionTA=LEGISCTA000023450938\&cidTexte=LEGITEXT000006070716\&dateTexte }=2013020}$ $\underline{1}$; consulta em 21.02.2014.

111 ThOMAS Clay. L'application perlée du règlement d'arbitrage pour la contestation des liens non révélés entre arbiter et conseil, in Revista de arbitragem e mediação, v. 33, 2012, pp. 179-188.

112 Detalhamento e críticas às orientações doutrinárias são dados por TOM PHILIPPE HEINTZ; GUSTAVO VIEIRA DA COSTA CERQUEIRA. A nova interpretação da obrigação de independência do árbitro na França: ad extirpanda?, in Revista de arbitragem e mediação, v. 32, 2012, pp. 405-408. 
texto legal aos mais variados casos, oportuniza o surgimento de interpretações inconsistentes, na inversa proporção em que não forem esclarecidas as premissas de operacionalização $^{113}$, a exemplo do que ocorreu no caso Tecso v. Neoelectra Group ${ }^{114}$, no qual a Corte de Apelação de Paris, em 10.03.2011, analisou as premissas colocadas por ambas as partes em ação anulatória de sentença arbitral que havia sido proferida em 04.06.2009. Pela Tecso, foi afirmado que: (i) um dos árbitros teria violado o dever de revelação por não informar ter sido of counsel, entre fevereiro de 1989 a outubro de 2000, do escritório (Freshfields Bruckhaus Deringer) ao qual pertencia uma das advogadas que patrocinava, pessoalmente (e não em nome do escritório) uma das partes; e (ii) tal árbitro não teria revelado que havia sido consultado "duas ou três vezes como professor, para emitir uma opinião jurídica" pelo referido escritório, do qual dispunha de endereço eletrônico (e-mail), além de ter organizado colóquio em suas dependências. No curso da ação anulatória, foi esclarecido pela Neoelectra que: (iii) a advogada não atuava, na causa, em nome do escritório, e nele foi admitida somente após a saída do professor designado árbitro; e (iv) o colóquio realizado nas dependências do escritório foi organizado por iniciativa da Associação ligada à Université Paris II, dirigida pelo professor designado árbitro.

Em sentença, a Corte de Apelação de Paris entendeu que a consulta do escritório ao árbitro por duas ou três vezes caracterizaria "courant d'affaires", afirmando, ainda, que a não revelação dessa situação a tempo oportuno negou à Tecso o exercício do seu direito de recusa, além de estabelecer que a situação da advogada deveria ter sido revelada, mesmo na ausência de ligações pessoais com o árbitro ${ }^{115}$. A Corte de Cassação, em decisão de 10.12.2012, determinou que o juízo inferior fosse além de meras inferências e apurasse, em concreto, em que medida os fatos não revelados poderiam levar a dúvidas justificadas quanto à imparcialidade e independência do árbitro ${ }^{116}$.

\footnotetext{
113 Tratadas no capítulo 2 do presente estudo.

${ }^{114}$ Cópia da decisão da Corte de Cassação e sua percuriente análise, amplamente aproveitada neste estudo, é feita por Tom PhILIPPE HeINTZ; Gustavo VIEIRA DA COSTA CERQUEIRA. Racionalização do dever de revelação no direito francês da arbitragem, in Revista de arbitragem e mediação, v. 362, 2012, pp. 411-431.

115 TOM PHILIPPE HeInTZ; GuSTAVo VIEIRA DA COSTA CERQUEIRA. Racionalização... op. cit., p. 418.

${ }^{116}$ TOM PhILIPPE HeInTZ; Gustavo VIEIRA DA Costa CERQUEIRA. Racionalização... op. cit., p. 418.
} 
Não obstante as incontornáveis flutuações interpretativas, a evolução da experiência francesa - calcada na casuística e na jurisprudência - fornece importante material no que diz respeito à padronização da imparcialidade do árbitro.

\subsubsection{Técnicas de padronização na experiência da common law ${ }^{117}$}

\subsubsection{A experiência inglesa e a disputa entre testes para aferição da imparcialidade}

A Inglaterra não desconhece a regulamentação legal da arbitragem, especialmente no que diz respeito à imparcialidade do árbitro. Era assim no Arbitration Act inglês de 1950 (alterado e complementado por modificações legislativas de 1966, 1975 e 1979), o qual previa apenas que a sentença arbitral poderia ser invalidada caso o árbitro não tivesse conduta apropriada ou não desse condução apropriada ao processo ${ }^{118}$, e assim continuou no Arbitration Act de $1996^{119}$ atualmente em vigor, que enuncia, entre os princípios gerais aplicáveis ao instituto (Section $1(a)$ ), ser o objeto da arbitragem a obtenção de uma resolução justa das disputas por um tribunal imparcial, sem atrasos ou encargos desnecessários. Mais especificamente, na seção dedicada aos deveres do tribunal arbitral, a lei impõe sua atuação com justiça e imparcialidade, com atribuição a cada parte de uma oportunidade razoável de expor o seu caso e lidar com a exposição de seu adversário (Section 33(1)(a)). O Arbitration Act qualifica como grave irregularidade a violação dos deveres da Section 33 que causem injustiça substancial a uma das partes (Section 68(2)(a)), estabelecendo como consequência a invalidade e a ineficácia da sentença arbitral (Section 68(3)(a) e Section 68(3)(c)). Além dessa disciplina, o Arbitration Act prevê a possibilidade de a parte em processo arbitral recorrer ao Poder Judiciário para remoção de árbitro, se

\footnotetext{
${ }^{117}$ A expressão "commom law" identifica experiências jurídicas que possuem orientações comuns relativas à sua gênese e desenvolvimento, normas, doutrinas, princípios e padrões. Isso não significa esquecer que tais sistemas possuem suas particularidades, podendo se falar, por exemplo, na common law norte-americana, inglesa, australiana, entre outras. Nesse sentido, LEON TRAKMAN. "Legal traditions" and international commercial arbitration, in The american review of international arbitration, v. 17, n. 1, 2006, p. 11.

${ }^{118}$ No original, "Where an arbitrator or umpire has misconducted himself or the proceedings", conforme Section 23(2). O Arbitration Act 1950 está disponível no endereço eletrônico http://www.legislation.gov.uk/ukpga/Geo6/14/27/contents; consulta em 21.02.2014.

$119 \begin{array}{cccccc}\text { Arbitration } & \text { Act } & \text { 1996, disponível } & \text { no } & \text { endereço } & \text { eletrônico }\end{array}$
}


houver circunstância que dê origem a dúvidas justificadas sobre a sua imparcialidade (Section 24(1)(a)).

Como a lei não estabelece critérios operativos de avaliação da imparcialidade e como é da própria tradição do common law a vinculação aos precedentes judiciais, a doutrina e a jurisprudência reconhecem as decisões judiciais como fundamentais ${ }^{120}$ para o entendimento do tema ${ }^{121}$. Tais decisões estabeleceram uma série de testes para a identificação e mensuração da imparcialidade dos julgadores em geral e dos árbitros em particular. Sob esse aspecto, foi o julgamento do caso R. v Sussex Justices, ex parte McCarthy o leading case a respeito da imparcialidade dos juízes, ampliando o entendimento (então mais restritivo) utilizado no antigo caso Dimes v Grand Junction Canal $^{122}$, limitado ao brocardo nemo judex in sua causa, assim entendido como proibição de atuação do julgador em causa cujo resultado comprovadamente implicar seu benefício (patrimonial) direto ${ }^{123}$.

No caso R. v Sussex Justices ${ }^{124}{ }^{125}$, estabeleceu-se que a mera aparência de parcialidade é suficiente para anular uma decisão judicial, conforme entendimento consolidado no dictum do Lord Hewart, segundo o qual "a justiça não apenas deve ser feita, mas deve ser

\footnotetext{
120 "Na Common Law, a idéia que permeia o sistema é de que o direito existe não para ser um edifício lógico e sistemático, mas para resolver questões concretas." GUIDO FERNANDO SILVA SOARES. Common law... op. cit., p. 53.

${ }^{121}$ Com referência a diversos estudos e julgados, BEATRICE ZUFFI. L'arbitrato nel diritto inglese. Torino: Giappichelli, 2008, pp. 220-234.

${ }^{122}$ O caso Dimes, julgado pela Casa dos Lordes ("House of Lords") em 1852, envolveu a impugnação do julgador, Lord Cottenham, no julgamento de um caso que envolvia uma sociedade na qual ele detinha participação substancial. Referências sobre o caso podem ser obtidas no endereço eletrônico http://swarb.co.uk/?search-class=DB CustomSearch_Widget-

$\mathrm{db}$ customsearch widget\&search $=$ Search\&widget number $=2 \&$ cs-post title-

$0=$ The+Grand+Junction+Canal+Company+-v-+Dimes; consulta em 21.02.2014.

${ }^{123}$ Sobre a causa restritiva de impugnação ao interesse pecuniário, com apresentação de casoS julgados nos séculos XVI e XVII, vide JoHn P. Frank. Disqualification of judges, in Yale law journal, v. 56, 1947, pp. 609-612.

${ }^{124}$ Dada a quantidade de casos, optou-se por narrá-los em notas de rodapé, tomando assim menos espaço do texto principal.

${ }^{125}$ No caso, um motociclista (McCarthy) envolveu-se em um acidente que resultou em processo judicial perante o juízo criminal de primeiro grau ("Magistrate's Court") sob a acusação de direção perigosa. O escrivão do juízo que atuava no caso em questão era também membro ("solicitor") da banca de advogados que patrocinava ação cível contra o réu, relativa ao mesmo acidente. O escrivão retirou-se com os julgadores quando estes deliberaram o julgamento e retornaram com a condenação do réu. Mesmo com a declaração dos julgadores de que haviam concebido a decisão sem consultar o escrivão, a corte superior ("King's Bench") anulou a decisão em razão da aparência de parcialidade.
} 
manifesta e indubitavelmente ser vista como feita" ${ }^{126}$. No caso em questão, a imparcialidade dos julgadores foi identificada e mensurada segundo o teste que ficou conhecido como "reasonable apprehension of bias", que envolve duas operações básicas: a primeira é a determinação das circunstâncias importantes para serem avaliadas do ponto de vista de um observador razoável; a segunda é a avaliação propriamente dita dessas circunstâncias para identificação de uma razoável apreensão de parcialidade, no sentido de uma suspeita - subjetiva, portanto - de que ela tenha ocorrido ${ }^{127}$.

Nova evolução jurisprudencial seguiu-se no caso $R$. v Gough ${ }^{128}$, em cuja decisão foram analisados diversos julgados anteriores e identificados dois testes relativos à imparcialidade dos julgadores comumente aplicados pelas cortes inglesas, quais sejam, o "reasonable apprehension of bias" já mencionado, e o "real danger of bias", ao final aplicado no caso em questão.

No caso Gough foi consolidada orientação ao teste "real danger of bias", que envolve a operação de identificar quais fatos poderiam ser entendidos como prejudiciais à imparcialidade pelos próprios julgadores - afastando, aí, a noção do observador razoável $^{129}-\mathrm{e}$, com base nas circunstâncias do caso, avaliar se houve o real perigo (e não apenas suspeita) de imparcialidade do julgador, no sentido de que ele poderia ser influenciado por tais fatos e decidir injustamente em favor ou desfavor de uma das $\operatorname{partes}^{130}$.

\footnotetext{
${ }^{126}$ No original: "justice should not only be done but should manifestly and undoubtedly be seen to be done." Caso [1924] 1 K.B. 256. Referência ao caso no endereço eletrônico http://johnhemming.blogspot.com.br/2011/04/r-v-sussex-justices-ex-p-mccarthy-1924.html; consulta em 21.02 .2014 .

${ }^{127}$ SAMUel Ross LutTRell. Bias... op. cit., pp. 41-42.

${ }^{128}$ No caso, descobriu-se que uma jurada em julgamento de roubos era vizinha do irmão do réu (irmão esse também originalmente acusado, mas posteriormente excluído da demanda antes do julgamento), ao final condenado. A jurada declarou que desconhecia o fato no curso do julgamento e apresentou declaração nesse sentido. Considerando que a jurada não conhecia o fato, a Casa dos Lordes ponderou que ela não poderia ter sido influenciada por ele. R. v Gogh, [1993] 2 All E. R. 724, cuja íntegra da decisão pode ser obtida em http://www.law.hku.hk/conlawhk/sourcebook/admlawcases/Gough.htm; consulta em 21.02.2014.

${ }^{129}$ Conforme as palavras de Lord Goff: "I think it is unnecessary, in formulating the appropriate test, to require that the court should look at the matter through the eyes of a reasonable man, because the court in cases such as these personifies the reasonable man".

${ }^{130}$ Também nas palavras de Lord Goff: "Accordingly, having ascertained the relevant circumstances, the court should ask itself whether, having regard to those circumstances, there was a real danger of bias on the part of the relevant member of the tribunal in question, in the sense that he might unfairly regard (or have unfairly regarded) with favour, or disfavour, the case of a party to the issue under consideration by him".
} 
Tão importante quanto a mudança do observador, a divergência entre o teste "reasonable apprehension of bias" e o teste "real danger of bias" deu-se no que diz respeito à premissa de que a apreensão é subjetiva, porque ligada a um estado mental, ao passo que o perigo real se baseia mais nas evidências objetivas do que na percepção de um indivíduo ou das próprias partes $^{131}$.

O teste "real danger of bias" deixou de vincular as cortes inglesas a partir do julgamento do caso Porter $v$ Magill $^{132}$. Sob a premissa de proceder a um modesto ajuste no teste aplicado ao caso Gough, a Casa dos Lordes (acompanhando o voto de Lord Hope) sugeriu a retirada da referência ao "real danger of bias" e sua substituição pela referência ao "real possibility of bias", iniciando um cisma a respeito da real distinção entre ambos os termos. Atualmente, alguns entendem que a alteração leva a uma mudança na operação do teste "real danger of bias", de modo a serem identificadas todas as circunstâncias que sugerem que o julgador não seja imparcial, para posterior avaliação da possibilidade (e não mais do perigo) de imparcialidade sob o ponto de vista de um observador informado (e não apenas razoável $)^{133}$, ao passo que outros entendem que a alteração de referência é meramente semântica $^{134}$.

\footnotetext{
${ }^{131}$ SAMUel Ross LutTRell. Bias... op. cit., p. 42.

${ }^{132}$ No caso, a líder do Westminster City Council, Shirley Porter, desenvolveu uma política de vender imóveis pertencentes à administração em áreas capazes de eleger representantes no City Council (denominadas "marginal wards"), para aumentar a proporção de eleitores do Partido Conservador nessas áreas. As casas foram vendidas com desconto, levando a auditoria a concluir que Porter deveria restituir à cidade o valor de $£ 31$ milhões. Porter apelou ao Poder Judiciário, sob a alegação de que havia aparência de tendenciosidade ("bias") do auditor em razão das suas declarações em uma conferência de imprensa. Ao final, a Casa dos Lordes concluiu, com o voto de Lord Hope, que o teste envolvia "whether the fair-minded and informed observer, having considered the facts, would conclude that there was a real possibility that the tribunal was biased". Caso [2001] UKHL 67, cuja íntegra da decisão pode ser obtida em http://www.publications.parliament.uk/pa/ld200102/ldjudgmt/jd011213/magill-1.htm; consulta em 21.02.2014.

${ }^{133}$ Nas palavras de Lord Baker: "The test for apparent bias involves a two stage process. First the Court must ascertain all the circumstances which have a bearing on the suggestion that the tribunal was biased. Secondly it must ask itself whether those circumstances would lead a fair minded and informed observer to conclude that there was a real possibility that the tribunal was biased". Caso Flaherty v. National Greyhound Racing Club Ltd. [2005] EWCA Civ 1117. Decisão disponível no endereço eletrônico http://www.bailii.org/ew/cases/EWCA/Civ/2005/1117.html; consulta em 21.02.2014.

${ }^{134}$ Nas palavras de Lord Phillips, ao comentar o que o julgador deve fazer nos casos de impugnação de árbitro: "It must then ask whether those circumstances would lead a fair-minded and informed observer to conclude that there was a real possibility, or a real danger, the two being the same, that the tribunal was biased". Caso In Re Medicaments and Related Classes of Goods (No 2) [2001] 1 WLR 700, CA. Decisão disponível no endereço eletrônico http://www.bailii.org/ew/cases/EWCA/Civ/2000/350.html; consulta em 21.02.2014.
} 
Os diferentes testes relativos à imparcialidade dos juízes foram aplicados em decisões sobre a imparcialidade dos árbitros. Por exemplo, no caso Norbrook Laboratories Ltd. $v$. $\operatorname{Tank}^{135}$, no qual há expressa referência ao teste "real possibility of bias" pela declaração de que um observador bem informado concluiria haver a real possibilidade de o julgador ser tendencioso ${ }^{136}$, há quem sustente que o teste utilizado foi o "real danger of bias"137. Mais clara aplicação do teste "real danger of bias" foi feita no caso Laker Airways Inc. v. FLS Aerospace $L t d .{ }^{138}$, no qual os julgadores declararam buscar a identificação de um real perigo de parcialidade ${ }^{139}$. A decisão no caso $A T \& T$ v. Saudi Cable $e^{140}$ também optou pelo teste "real danger of bias", embora tenha considerado que tal teste, assim como o do "reasonable apprehension of bias", leva, na prática, ao mesmo resultado ao apartar um perigo real de um perigo imaginado por uma das partes quanto à parcialidade do árbitro ${ }^{141}$.

${ }^{135}$ Caso Norbrook Laboratories Ltd v Tank, [2006] APP.L.R. 05/12. Decisão disponível no endereço eletrônico http://www.nadr.co.uk/articles/published/ArbLawReports/Norbrook\%20v\%20Tank\%202006.pdf; consulta em 21.02.2014. No caso, o árbitro único, a pretexto de reduzir os custos da arbitragem, contatou e questionou, sozinho e diretamente, três testemunhas por telefone, sem consultar previamente as partes e sem guardar registro das conversas.

${ }^{136}$ No original: "I have no doubt that the fair minded and informed observer, having considered all the facts in the case relating to contact eith the three witnesses would conclude that there was a real possibility that the tribunal was biased."

${ }^{137}$ É o que faz SAMUEL Ross LutTRELl. Bias... op. cit., p. 52.

${ }^{138}$ Caso Laker Airways Inc. v FLS Aerospace Ltd., [1999]. Decisão disponível no endereço eletrônico http://old.simic.net.cn/upload/2010-06/20100609140146968.pdf; consulta em 21.02.2014.

${ }^{139}$ No caso, a FLS requereu ao Queen's Bench a remoção do árbitro com base em três alegações: $(i)$ pelo fato de ambos serem advogados ("barristers") e pertencerem à mesma câmara ("chamber"), o advogado da FLS (Michael Sullivan) e o árbitro indicado por ela (Stanley Burnton) teriam inerente conflito de interesses, o que impediria o primeiro de agir imparcialmente; (ii) existência de risco de que informações sobre o caso fossem trocadas entre o árbitro e o advogado fora do processo arbitral; e (iii) o julgamento do árbitro poderia ser influenciado pela sua familiaridade com o advogado. O Queen's Bench afastou a primeira alegação com base em jurisprudência já consolidada quanto à organização da advocacia inglesa em câmaras e sua irrelevância per se à imparcialidade do árbitro, notando que o fato de árbitro e advogado praticarem a profissão e eventualmente se contraporem não gera conflito de interesses entre eles (profissionais), mas entre as partes que, respectivamente, defendem. A mesma corte afastou a segunda alegação por notar que não há relação de parceria ou de emprego entre profissionais da mesma câmara, de modo que deveria ser demonstrado que a própria existência e organização das câmaras daria causa a dúvidas justificadas sobre a imparcialidade do árbitro pelo perigo da disseminação imprópria de informações confidenciais. A terceira alegação foi afastada não apenas porque advogado e árbitro mal se conheciam, mas porque as câmaras são locais onde a competição e o coleguismo entre os profissionais não solapa o fato de que elas são compostas por profissionais independentes que não compartilham a carreira ou a remuneração.

${ }^{140}$ Caso AT\&T Corporation v Saudi Cable Co [2000] APP.L.R. 05/15. Decisão disponível no endereço eletrônico http://www.nadr.co.uk/articles/published/ArbitrationLawR/AT\&T\%20v\%20Saudi\%202000.pdf; consulta em 21.02.2014.

${ }^{141}$ No caso, as partes disputavam sobre um contrato que tinham celebrado entre si em razão da participação (e posterior vitória) da AT\&T em concorrência pública para o projeto de expansão do serviço de telecomunicações na Arábia Saudita. A AT\&T requereu a invalidação de sentença parcial proferida pelo tribunal arbitral pelo fato de o árbitro indicado pela Saudi Cable (Yves Frontier) não ter revelado que era diretor não executivo da empresa Nortel, concorrente vencida pela AT\&T na concorrência, nem que possuía 474 ações dessa companhia. O pedido de invalidação foi afastado pela House of Lords pelas considerações 
Mais clara foi a decisão do caso ASM Shipping $v T_{T M I^{142}}$, no qual ambas as partes se basearam no teste "real possibility of bias", sendo esclarecido que, diante das circunstâncias do caso, um observador independente iria concluir que havia uma real possibilidade de o tribunal estar enviesado.

A rica experiência inglesa decantou diferentes "testes" para aferição da imparcialidade e pavimentou a aplicação do teste "real possibility of bias" utilizado no caso In $R e$ Medicaments ${ }^{143}$. Ainda que tais "testes" envolvam aparente confusão de conceitos e de pontos de vista de observadores, seu estudo é útil para auxiliar na eleição das premissas de operacionalização sugeridas no presente estudo.

\subsubsection{2. $\quad$ A experiência norte-americana e a vagueza do conceito de "evident partiality"}

Assim como ocorreu com a jurisprudência inglesa, a noção inicialmente restrita de imparcialidade do juiz, derivada da inexistência de interesse pessoal ou pecuniário direto na causa (nemo iudex in causa sua), foi ampliada na legislação norte-americana. Já em

expostas no voto de Lord Woolf: $(i)$ a decisão sobre a imparcialidade deve levar em conta critérios objetivos; (ii) o árbitro não sabia que a Nortel havia participado da concorrência quando fez suas revelações; (iii) eventual benefício indireto que o resultado da arbitragem traria à Nortel seria tão mínimo para o árbitro que não seria razoável que isso pudesse tê-lo influenciado; (iv) o envolvimento do árbitro com a Nortel era limitado e foi acuradamente descrito como incidental na sua vida profissional; $(v)$ o árbitro não dava importância ao seu envolvimento com a Nortel, tanto que, assim que a ligação foi apontada pela AT\&T na arbitragem, o árbitro prontamente ofereceu-se para renunciar à diretoria; e (vi) não houve qualquer atitude do árbitro no curso da arbitragem que sugerisse tendenciosidade contra qualquer das partes.

${ }^{142}$ Caso ASM Shipping Ltd of India v TTMI Ltd of England [2005] APP.L.R. 10/19. No caso, o árbitro presidente (Mathews) havia funcionado, em outro e não relacionado processo arbitral, como advogado sob a orientação dos mesmos advogados que agora representavam uma das partes, no intuito de demonstrar (mediante o procedimento de disclosure de documentos) a falta de integridade e desonestidade de uma das testemunhas (Moustakas). Na arbitragem cujo painel era presidido por Mathews, iniciada 7 meses após o procedimento de disclosure na arbitragem prévia, Moustakas era a principal testemunha de uma das partes e sobre ele também pesavam acusações de desonestidade. Foi requerido o afastamento judicial do árbitro presidente, sendo que o julgamento em primeiro grau reconheceu, pelo teste "real possibility of bias", o fundamento para o afastamento do julgador, não o fazendo por considerar que a impugnação do árbitro havia sido extemporânea. Posteriormente, o árbitro renunciou ao encargo. O julgamento de primeiro grau está disponível no endereço eletrônico http://www.nadr.co.uk/articles/published/ArbitrationLawRep/ASM\%20v\%20TTMI\%202005.pdf; consulta em 21.02.2014.

${ }^{143}$ Apontando, de forma sucinta, a disputa entre os “testes”, SAMUEL Ross LUTTRELL. Bias... op. cit., pp. 5961. 
1792, o Congresso norte-americano editou a primeira lei sobre o tema, que adicionava ao motivo clássico de impugnação, então reconhecido jurisprudencialmente, a hipótese de o juiz ter advogado anteriormente para uma das $\operatorname{partes}^{144}$. A lei foi emendada sucessivamente para a integração de outras hipóteses e de diferentes procedimentos relativos ao incidente de impugnação, que é disciplinado na esfera federal, atualmente, nas Sections 144 e 455 das Federal Rules of Civil Procedure ${ }^{145}$, tendo sido sempre influenciada - no sentido do seu alargamento interpretativo - pela jurisprudência ${ }^{146}$.

A experiência desenvolvida no tema da imparcialidade dos juízes ensejou a adoção de regras consolidadas na Section 10 do Federal Arbitration Act (FAA) ${ }^{147}$, o texto sancionador da imparcialidade do árbitro em âmbito federal nos Estados Unidos, que prevê a anulação da sentença arbitral proferida mediante corrupção, fraude ou utilização de meios indevidos (Section 10(a)(1)); ou quando for constatada a "evidente parcialidade" ou corrupção do árbitro (Section 10(a)(2)).

Foi o julgamento do caso Commonwealth Coatings v. Continental Casualty ${ }^{148}$, pela Suprema Corte norte-americana, que fixou os fundamentos da análise - com vertentes muitas vezes contraditórias - da imparcialidade dos árbitros sob o FAA. O caso (o único em que o tema foi levado à Suprema Corte) envolvia árbitro presidente que, antes do início do procedimento arbitral, havia prestado consultoria a uma das partes, na qualidade de

\footnotetext{
${ }^{144}$ Sobre a evolução da legislação federal norte-americana relativa à imparcialidade dos juízes, vide RICHARD E. FlAMM. History of and problems with the federal judicial disqualification framework, in Drake law review, v. 58, 2010, sobretudo pp. 753-756.

${ }^{145}$ Excelente descrição das sucessivas reformas é feita por AMANDA FROST. Keeping up appearances: a process-oriented approach to judicial recusal, in University of Kansas law review, v. 35, 2005, pp. 538-550.

${ }^{146}$ Grande quantidade de decisões na esfera federal e sua respectiva fundamentação nas regras de impugnação dos juízes constantes das Federal Rules of Civil Procedure são trazidas em abrangente estudo feito por CHARLES GARDNER GEYH. Judicial disqualification: an analysis of Federal Law. 2. ed. Federal Judicial Center, 2010. Sobre casos recentes e problemáticos, tais como (i) o que envolveu o Justice Scalia (membro da Suprema Corte) e sua viagem com o então litigante Dick Cheney semanas após o julgamento do caso do qual era parte; (ii) o que envolveu a decisão do District Judge Martin Feldman, que revogou a moratória decretada pelo Presidente Obama para a prospecção de petróleo em águas profundas após o desastre no golfo do México (descobriu-se que o juiz detinha grande quantidade de ações de companhias petrolíferas, que foram vendidas no mesmo dia em que o juiz deu a decisão); ou (iii) que envolveu a discussão sobre a necessidade do District Judge Vaughn Walker, alegadamente homossexual, declarar-se ou não se declarar impedido para decidir sobre a constitucionalidade da vedação do casamento homoafetivo na constituição do Estado da Califórnia, vide DMITRY BAM. Making appearances matter: recusal and the appearance of bias, in Brigham Young University law review, v. 2011, 2011, pp. 945-947.
}

${ }^{147}$ Disponível no endereço eletrônico http://www.law.cornell.edu/uscode/text/9/10; consulta em 21.02.2014.

148 Extrato do julgamento disponível no endereço eletrônico https://bulk.resource.org/courts.gov/c/US/393/393.US.145.14.html; consulta em 21.02.2014. 
engenheiro, em relação ao projeto objeto da disputa, recebendo pelo trabalho a quantia de USD 12 mil. O árbitro não revelou tal fato e a sentença foi favorável, por unanimidade, à parte que tinha contratado a consulta.

Embora a Suprema Corte tenha revertido a decisão da instância inferior e anulado a sentença arbitral com a aplicação da Section $10(a)(2)$ do FAA, tendo em vista que a não revelação do negócio anterior seria demonstração de evidente parcialidade do árbitro presidente, não houve consenso claro de qual deveria ser o padrão para se aferir tal evidente parcialidade, gerando cisão no colegiado sobre: (i) se o padrão da imparcialidade do árbitro deveria ser equivalente ao do juiz; e (ii) se o negócio anterior entre árbitro e parte deveria ser substancial ou se qualquer envolvimento que causasse a mera impressão de tendenciosidade (“impression of bias") seria suficiente para o afastamento do árbitro ${ }^{149}$.

A corrente majoritária, encabeçada pelo Justice Black, entendeu equiparável o padrão de imparcialidade do árbitro ao padrão do juiz (fazendo menção ao $33^{\circ}$ Canon of Judicial Ethics) e estabeleceu que os árbitros devem revelar às partes qualquer negócio que possa criar a impressão de tendenciosidade, sendo que seu dever não seria apenas atuar sem tendenciosidade, mas também evitar qualquer aparência nesse sentido ${ }^{150}$. Por sua vez, a corrente encabeçada pelo Justice White (que proferiu voto concordante, mas com observações) fez apontamentos segundo os quais a imparcialidade do árbitro não deve ser medida pelo padrão aplicável ao juiz, defendendo ainda que os árbitros não devem ser afastados por relações de negócio com as partes se tais relações são triviais, mas que, ao contrário, tais relações devem ser substanciais para que a evidente imparcialidade fique caracterizada $^{151}$. No caso, o Justice White usou esse raciocínio para demonstrar que a relação do árbitro presidente, no caso sob julgamento, não foi trivial, pois envolvia remuneração significativa ${ }^{152}$.

\footnotetext{
${ }^{149}$ Análise detalhada da decisão foi feita por MERRICK T. ROSSEIN; JENNIFER HOPE. Disclosure and disqualification standards for neutral arbitrators: how far to cast the net and what is sufficient to vacate an award, in St. John's law review, v. 81, 2007, pp. 206-209.

${ }^{150}$ No original: "arbitrators must not only be unbiased but must also avoid even the appearance of bias".

${ }^{151}$ No original: "[arbitrators are not] automatically disqualified by a business relationship with the parties before them if are unaware of the fact but the relationship is trivial".

${ }^{152}$ No original: "But it is enough for present purposes to hold, as the Court does, that where the arbitrator has a substantial interest in a firm which has done more than trivial business with a party, that fact must be disclosed".
} 
Essa cisão entre os pontos de vista no caso Commonwealth Coatings influenciou decisões posteriores nos diferentes Circuitos da esfera judicial federal norte-americana, ensejando decisões desfavoráveis à equivalência do padrão de aferição de imparcialidade do árbitro ao do juiz, conforme se vê no caso International Produce, Inc. v. A/S Rosshavet ${ }^{153154}$, no qual se afirmou que aplicar aos árbitros os mesmos padrões (elevados) de imparcialidade aplicáveis aos juízes apenas serviria para afastar os árbitros mais capazes ${ }^{155}$. São registradas, entretanto, decisões que, em sentido oposto ao ora narrado, entenderam que os padrões de imparcialidade dos árbitros deveriam ser mais severos que aqueles aplicáveis aos juízes ${ }^{156}$.

Também é possível perceber na jurisprudência norte-americana a falta de orientação a respeito do padrão constitutivo da evidente parcialidade do árbitro. Alguns Circuitos impõem a anulação das sentenças pela razoável impressão de tendenciosidade, tal como

${ }^{153}$ Dada a quantidade de casos, optou-se por narrá-los em notas de rodapé, tomando assim menos espaço do texto principal.

${ }^{154}$ Caso International Produce, Inc. v. A/S Rosshavet, 638 F. 2d 548 ( $2^{\circ}$ Cir 1981), disponível no endereço eletrônico https://bulk.resource.org/courts.gov/c/F2/638/638.F2d.548.80-7387.132.html; consulta em 21.02.2014. No caso, os árbitros do painel (Lloyd Nelson, Mack Klosty e Hammond Cederholm) revelaram possíveis conflitos de interesses, pois: (i) Klosty havia sido indicado anteriormente como árbitro em disputas por uma das partes (International) e havia feito negócios com ela como broker; (ii) a empresa na qual Nelson desenvolvia suas atividades possuía uma longa relação de negócios com a controladora da Internacional; e (iii) o escritório que patrocinava a Rosshavet (Haight Gardner) também estava à frente de uma arbitragem em que era parte um dos clientes da empresa presidida por Cederhorn, cujo objeto envolvia uma embarcação nomeada Mary S. Ainda no curso do processo, surgiu outro conflito que envolvia a embarcação, no qual as partes foram, também, representadas pelos mesmos escritórios atuantes no caso em que Cederhorn era árbitro. Cederhorn foi arrolado, pelo seu cliente, como testemunha, razão pela qual o advogado (Carey) do escritório (Hill Rivkins) de uma das partes lhe telefonou, requerendo a sua renúncia, pois seria provável que o escritório que representava a outra parte (Haight Gardner) iria prepará-lo como testemunha, contato que seria incompatível com a posição de árbitro. Cederhorn foi encorajado pelos demais árbitros do painel a não renunciar, razão pela qual condicionou sua permanência à retirada do caso dos advogados que também atuassem no caso que envolvia Mary S., no que foi atendido pelo escritório Haight Gardner, mas não pelo escritório Hill Rivkins, que apenas requereu a produção de provas.

O Tribunal estatal, revertendo a decisão de primeiro grau que considerou a infringência da evidente parcialidade pelo contato de Cederhorn com ambos os escritórios, apontou que, diferentemente dos juízes, não é inusual que os profissionais selecionados como árbitros em conflitos marítimos tenham tido numerosos negócios com uma ou mais das partes ou com os seus advogados, e que os árbitros mais procurados sejam justamente os mais proeminentes e experientes membros da específica comunidade de negócios da qual emanam as disputas a serem arbitradas.

${ }^{155}$ No original: "We are convinced that the goals of the arbitration system would not be served if arbitrators and Article III judges were held to the same high standard. To vacate an arbitration award where nothing more than an appearance of bias is alleged would be 'automatically to disqualify the best informed and most capable potential arbitrators' ".

${ }^{156}$ Por todos, o próprio caso Commonwealth Coatings, em que se declarou: "It is true that arbitrators cannot sever all their ties with the business world, since they are not expected to get all their income from their work deciding cases, but we should, if anything, be even more scrupulous to safeguard the impartiality of arbitrators than judges, since the former have completely free rein to decide the law as well as the facts and are not subject to appellate review". 
ocorreu no caso Sanko S.S. Co. Ltd. v Cook Industries ${ }^{157}$, no qual se afirmou que o árbitro não deve fornecer às partes uma completa biografia profissional, mas apenas fornecer informações sobre negócios que criem uma impressão de possível tendenciosidade ("impression of possible bias") ${ }^{158}$. Outros Circuitos, no entanto, são mais restritivos conceitualmente, afastando tanto a aparência quanto a impressão como padrões constitutivos da "evidente imparcialidade", e exigindo a demonstração de um conflito efetivo de interesses ou de uma falha grave no cumprimento do dever de revelação do árbitro que leve a ofender o padrão de uma pessoa razoável. É o que se vê nos casos Gianelli Money v. ADM Investors ${ }^{159}$, no qual se afirmou que ocorre evidente parcialidade quando há um conflito real de interesses (“actual bias") ou quando o árbitro conhece e oculta informações que levariam uma pessoa razoável a crer que tal conflito de interesses exista $^{160}$; e no caso Lifecare International v. CD Medical ${ }^{161}$, no qual se afirmou que a

\footnotetext{
${ }^{157}$ Caso Sanko S.S. Co., Ltd. vs Cook Industries. 495 F.2d 1260, 1263 (2 Cir. 1973). Decisão disponível no endereço eletrônico https://bulk.resource.org/courts.gov/c/F2/495/495.F2d.1260.6.73-1355.html; consulta em 21.02.2014. No caso, o árbitro presidente teria informado que sua empresa (Sagus Marine Corporation) tinha tido negócios com uma das partes (Cook), sem, no entanto, informar várias outras conexões entre as empresas, entre elas, o fato de sua empresa ser uma afiliada da Louis Dreyfus Partnership of France, empresa essa que, como a Cook, era uma das maiores negociadoras mundiais de grãos, e que ambas firmavam entre si e com frequência swaps e vendas de commodities. Sanko, na busca da anulação da sentença, alegou que o presidente tinha interesse em dar uma decisão favorável à Cook para possibilitar que a Dreyfus pudesse retornar o favor no futuro, alegação essa que foi afastada no julgamento do caso pela Corte de Apelações do Segundo Circuito.
}

${ }^{158}$ No original: "To be sure, the broad disclosure called for in Commonwealth Coatings does not require that an arbitrator 'provide the parties with his complete and unexpurgated business biography.' 393 U.S. at 151, 89 S.Ct. at 340; Reed \& Martin, Inc. v. Westinghouse Elec. Corp., 439 F.2d 1268 (2d Cir. 1971). But where dealings 'might create an impression of possible bias', they must be disclosed."

${ }^{159}$ Caso Gianelli Money Purchase Plan and Trust v ADM Investor Services, Inc., 146 F.3d 1309 (11 Cir. 1998). Decisão disponível no endereço etrônico https://bulk.resource.org/courts.gov/c/F3/146/146.F3d.1309.97-2586.html; consulta em 21.02.2014. No caso, tanto o árbitro único indicado pelas partes quanto seu escritório haviam representado, em diversos negócios, o presidente (Kent C. Kelley) de uma empresa parceira de uma das partes (Basic Commodities, Inc., parceira da $\mathrm{ADM}$ ), inclusive no negócio que levou à arbitragem, em que tal empresa figurou como garante (embora não fosse parte no processo arbitral). O Tribunal considerou que inexistia conflito real de interesses (actual conflict), uma vez que o árbitro não conhecia os contatos passados do seu escritório com a empresa garantidora do negócio levado à arbitragem.

${ }^{160}$ No original: “(...) the district court should have applied the law of our Circuit, which is that an arbitration award may be vacated due to the "evident partiality" of an arbitrator only when either (1) an actual conflict exists, or (2) the arbitrator knows of, but fails to disclose, information which would lead a reasonable person to believe that a potential conflict exists."

${ }^{161}$ Caso Lifecare International, Inc. v CD Medical, Inc., 68 F. $3 \mathrm{~d} 429$ (11 Cir. 1995). Decisão disponível no endereço eletrônico https://bulk.resource.org/courts.gov/c/F3/68/68.F3d.429.94-4595.html; consulta em 21.02.2014. No caso, o coárbitro Craig Stein foi impugnado por duas razões.

A primeira razão envolveu uma narração feita pelo árbitro (também advogado) no intervalo da audiência, quando contou um situação por ele vivida, na qual o advogado com o qual litigava havia se recusado a reagendar uma audiência, o que o obrigou a viajar ao exterior, conduta que reputou antiprofissional e passível de punição disciplinar; posteriormente foi descoberto que o advogado ao qual o árbitro se referia havia trabalhado no escritório (White \& Case) que agora patrocinava uma das partes sujeitas à sua decisão e que o referido árbitro, quando do incidente, escreveu ao escritório e afirmou que uma banca do gabarito do White 
violação do dever de investigar as ligações pretéritas do escritório do árbitro com as partes da arbitragem não leva, automaticamente, à criação de uma razoável impressão de tendenciosidade ("reasonable impression of bias") ${ }^{162}$, ou ainda no caso Lucent Tech., Inc. v. Tatung Co. ${ }^{163}$, no qual, rejeitando a tese da "appearance of bias" e a tese da "proof of actual bias", o julgamento pendeu para a análise da existência ou não de "strong evidence of bias" ${ }^{\prime 64}$.

Há, efetivamente, pouca luz sobre as diferenças entre a aparência e a impressão, ainda mais quando caracterizadas como forte, razoável, possível ou justificável ou com outro qualificador qualquer. A despeito das tentativas de se mapear os critérios adotados pelos diferentes Circuitos da esfera judicial federal para a caracterização da evidente

\& Case não poderia admitir um comportamento como o apresentado pelo advogado. Relativamente à alegação de evidente parcialidade em razão do ocorrido, o Tribunal estatal entendeu que o desentendimento entre advogados faz parte da profissão e que seria de todo improvável que eventual animosidade que pudesse existir frente ao advogado fosse passada para todo o escritório e, posteriormente, também para a empresa que ele representa na arbitragem. Em suma, entendeu-se que o fato "is more in the line of remote, uncertain, and speculative partiality or a mere appearance of bias or partiality, as opposed to bias or partiality that is direct, definite, and capable of demonstration".

A segunda razão para a impugnação do árbitro derivou do fato de ele não ter revelado que, poucos meses antes de ser nomeado para o caso (o que ocorreu em novembro de 1992), havia se tornado of counsel do escritório Greenbert Traurig, banca que havia sido contatada em 1988 para revisar um aditamento a um contrato estabelecido entre as duas partes na arbitragem e que uma delas (CD Medical), em janeiro de 1990, procurou novamente o escritório para representá-la na arbitragem. O Tribunal estatal entendeu que o árbitro não tinha ciência dos contatos entre o escritório do qual era of counsel e uma das partes da arbitragem, e assim a falha do árbitro em investigar e revelar tais contatos não criaria uma razoável impressão de tendenciosidade ou parcialidade.

Em conclusão, no entendimento do Tribunal, a mera aparência de imparcialidade seria insuficiente para caracterizar a "evidente parcialidade" e para a consequente anulação da sentença arbitral.

${ }^{162}$ No original: “(...) we cannot conclude that Arbitrator Stein's failure to investigate and, of course, disclose the two prior contacts between [office] and [party] creates a reasonable impression of bias or partiality."

${ }^{163}$ Caso Lucent Tech., Inc. v. Tatung Co., 379 F.3d 24, 29 (2d Cir. 2004). Decisão disponível no endereço eletrônico https://bulk.resource.org/courts.gov/c/F3/379/379.F3d.24.03-7741.html; consulta em 21.02.2014. No caso, a empresa Lucent instaurou - e venceu - procedimento arbitral contra a empresa Tatung, no qual pleiteava o pagamento de royalties objeto de um contrato de uso de patente. A Lucent indicou o árbitro David Luening e a Tatung indicou Ed Fiorito, árbitros que escolheram como presidente Roger Smith. Leuning revelou que havia sido contratado com advogado pela Lucent (através do escritório Kirkland \& Ellis) em questão não ligada à arbitragem, prestando serviços entre abril de 1998 e dezembro de 1999. Smith também revelou que foi advogado de uma banca que trabalhou para a Lucent. As revelações foram enviadas para a AAA mas, aparentemente, a Tatung jamais recebeu cópia dos documentos. Na discussão judicial que se seguiu sobre a parcialidade dos árbitros, a Corte de Apelação do Segundo Circuito acatou a decisão do juiz de primeiro grau que considerou que "Luening's prior relationship with Lucent had terminated in all material respects before Lucent's counsel solicited his services as an arbitrator in this matter" e que não acataria o pedido de disclosure para investigar a ligação de Smith com a Lucent. Sobre o não recebimento dos documentos de revelação, a Corte de Apelação considerou que a Tatung poderia ter, a qualquer momento no curso da arbitragem (que durou dois anos) ter requerido os documentos que alegou não ter recebido.

${ }^{164}$ No original: “we rejected both 'appearance of bias' and 'proof of actual bias' tests of evident partiality (...)" e "[n] othing about the relationship provides strong evidence of partiality by the arbitrator that would justify vacating the award." 
parcialidade estabelecida na lei, o que se assiste é a ausência de uma orientação comum ${ }^{165}$ e até mesmo a assimetria de análises entre Circuitos que, em tese, adotam um mesmo critério $^{166}$.

A complicar ainda mais a identificação de uma orientação clara sobre o padrão de imparcialidade do árbitro na experiência jurídica norte-americana, há a prática de formação de tribunais com árbitros não neutros ("nonneutrals"), sufragada pelo Code of Ethics for Arbitrators in Commercial Disputes adotado conjuntamente pela American Arbitration Association (AAA) e pela American Bar Association (ABA) em 1997. Segundo essa prática (entendida pela doutrina ${ }^{167}$ e pela jurisprudência ${ }^{168}$ como não coibida pelo FAA), se as partes expressamente a escolheram, o árbitro indicado pela parte opera como um amálgama de advogado e julgador, com esperada predisposição à tese a ser defendida pela parte que o escolheu, embora tal predisposição não deva ser aguda a ponto de afetar sua imparcialidade ${ }^{169}$. Segundo certa corrente, o árbitro não neutro opera como um amigo, que deve ser independente o suficiente para julgar contra a parte que o indicou se, nesse sentido, apontarem os elementos dos autos, assegurando, entretanto, que todos os argumentos da parte que o indicou serão completa e adequadamente ouvidos ${ }^{170}$. Há aqui, mais uma vez, um zona cinzenta sobre quais fatos caracterizariam propriamente a falta de

165 Em superficial, mas didática análise de alguns Circuitos, SHIVANI SINGHAL. Independence and impartiality of arbitrators, in International arbitration law review, v. 11, 2008, pp. 129-130.

${ }^{166}$ GARY BORN. The different meanings of an arbitrator's "evident partiality” under U.S. law, postado no Kluwer arbitration blog em 20.03.2013. Disponível no endereço eletrônico http://kluwerarbitrationblog.com/blog/2013/03/20/the-different-meanings-of-an-arbitrators-evident-partialityunder-u-s-law/; consulta em 21.02.2014.

${ }^{167}$ DAVID J. MCLEAN; SEAN-PATRICK WILSON. Is three a crowd? Neutrality, partiality and partisanship in the context of tripartite arbitrations, in Pepperdine dispute resolution law journal, v. 9, n. 1, 2012, pp. 170171.

${ }^{168}$ Caso Sphere Drake Ins. Ltd. v. All American Life Ins., 307 F.3d 617 (7º Cir. 2002), no qual se lê que "Parties are free to choose for themselves to what lengths they will go in quest of impartiality. Section $10(a)(2)$ just states the presumptive rule, subject to variation by mutual consent.". Decisão disponível no endereço eletrônico https://bulk.resource.org/courts.gov/c/F3/307/307.F3d.617.02-2458.html; consulta em 21.02.2014.

${ }^{169}$ Literalmente: "As everyone knows, the party's named arbitrator in this type of tribunal is an amalgam of judge and advocate. (...) He is, or may be, a somewhat interested participant in the panel's hearings and deliberations. His questions to witnesses and counsel, his comments along the way, his observations during interim deliberations may have subtle and possibly decisive impacts upon the end result". Caso Cia de Navegacion Omsil, S.A. v. Hugo Neu Corporation, 359 F.Supp. 898 (1973). Decisão disponível no endereço eletrônico

http://www.leagle.com/xmlResult.aspx?xmldoc=19731257359FSupp898 11109.xml\&docbase=CSLWAR11950-1985; consulta em 21.02.2014.

${ }^{170}$ JACQUES WERNER. The Independence of party-appointed arbitrators: for a rule of reason, in Journal of international arbitration, v. 7, n. 2, 1990, p. 5. 
independência do árbitro não neutro, pois, enquanto alguns julgados afirmam a inaplicabilidade do padrão da evidente parcialidade do FAA à espécie ${ }^{171}$, outros aplicam as regras sancionadoras desse regramento ao árbitro não neutro que não revelou ter mantido comunicações com a parte que o escolheu sobre o mérito da causa antes da escolha do árbitro presidente (as comunicações poderiam ter sido feitas, conquanto informada a sua ocorrência) e que, ainda que não neutro, "deveria ter participado do processo arbitral de um modo justo, honesto e de boa-fé" ${ }^{172}$. A aplicação das regras sancionadoras também ocorreu em caso no qual o árbitro não neutro deixou de revelar que era um credor de longa data da parte que o indicou, em decisão que praticamente igualou ao menos o dever de revelação dos árbitros não neutros aos neutros ${ }^{173}$. A prática do árbitro não neutro, tida por alguns como algo de constrangedor para a experiência arbitral norteamericana ${ }^{174}$, passou a figurar como exceção em vista da experiência arbitral internacional, que exige os mesmos padrões de independência e imparcialidade para todos os membros do tribunal ${ }^{175}$. No entanto, ainda há quem defenda a prática, apontando que a imparcialidade requerida dos coárbitros nas arbitragens internacionais não passaria de um mito $^{176}$.

$\mathrm{Na}$ esfera estadual, todos os Estados possuem sua própria legislação sobre arbitragem ${ }^{177}$. Do total, quatorze Estados e o distrito de Colúmbia adotaram o Revised Uniform

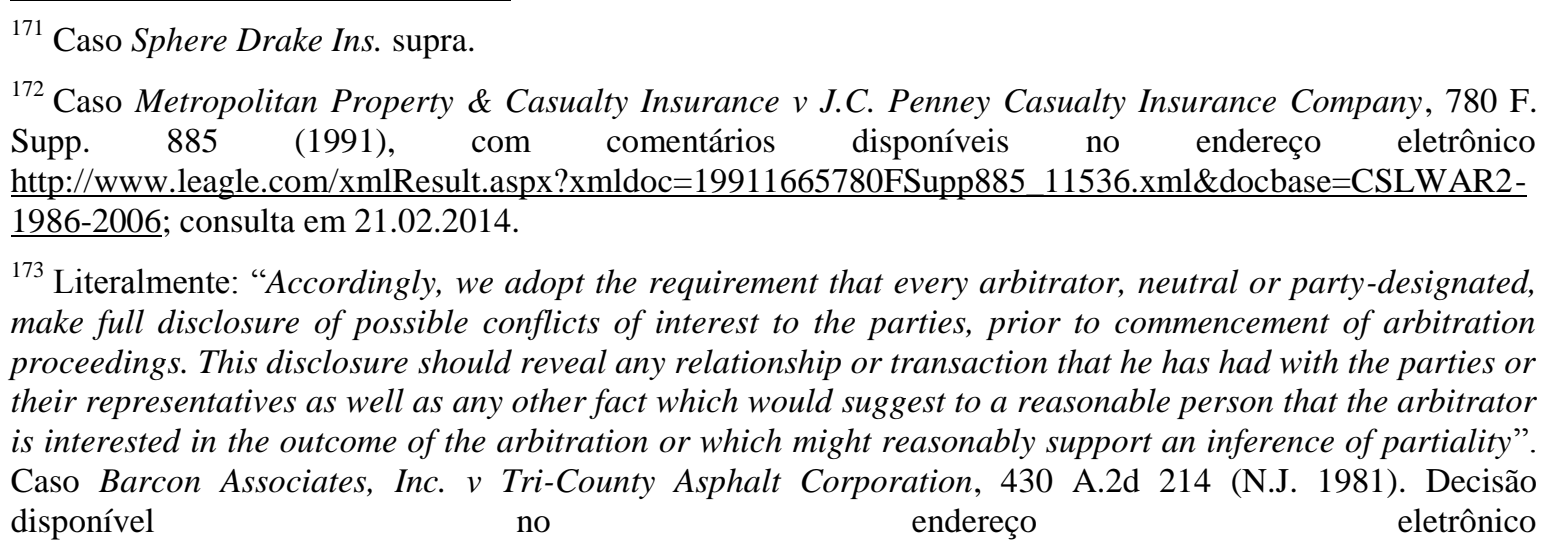
http://www.leagle.com/xmlResult.aspx?xmldoc=198126586NJ179_1252.xml\&docbase=CSLWAR1-19501985; consulta em 21.02.2014.

${ }^{174}$ JAMES H. CARTER. Improving life with the party-appointed arbitrator: clearer conduct guidelines for 'nonneutrals', in American review of international arbitration, v. 11, 2000, p. 305.

${ }^{175}$ DAVID J. MCLEAN; SEAN-PATRICK WILSON. Is three... op. cit., pp. 174-175.

176 "When the Continental jurist writes that a party-appointed arbitrator must be impartial - but can be impartial 'in his own fashion' (...) the potential for ambiguity, uncertaninty and confusion seems obvious." ALAN SCOTT RAU. Integrity in private judging, in South Texas law review, v. 38, 1997, p. 508.

${ }^{177}$ SAMUEL Ross LUTTRELL. Bias... op. cit., p. 145. 
Arbitration Act (RUAA) ${ }^{178}$, que repete a fórmula da evidente parcialidade e a consequente invalidação da sentença $($ Rule 23(1)(A)), deixando claro, no entanto, que o árbitro deve fazer uma pesquisa razoável ("a reasonable inquiry”) sobre matérias que possam afetar sua imparcialidade ou independência na visão de uma pessoa razoável (Section 12). Outros cinco Estados possuem legislação derivada da Lei Modelo UNCITRAL, com especial destaque para o Estado da Califórnia, que, em resposta à falta de confiança pública no método arbitral em razão da inserção de cláusula compromissória em contratos de consumo e de abusos por parte de instituições de arbitragem ${ }^{179}$, adicionou ao texto importantes mudanças e dispositivos, entre eles, o dever de o árbitro revelar se seu cônjuge ou seus filhos que com ele convivam têm interesse financeiro na matéria controvertida ou na parte da arbitragem (Rule 1297.121 (d)); ou se familiar até terceiro grau do árbitro ou de seu cônjuge for parte, diretor ou gerente da parte, ter atuado ou estar atuando como advogado no procedimento ou tenha interesse que possa ser substancialmente afetado pelo resultado na arbitragem (Rule 1297.121(e) ${ }^{180}$. Pela abrangência de hipóteses, que praticamente inviabilizam ao árbitro cumprir adequadamente o dever de revelação, a lei californiana foi objeto de severas críticas ${ }^{181}$.

A breve análise da experiência norte-americana no que se refere à imparcialidade dos árbitros revela a insuficiência de um mero conceito (no caso, a "evident partiality"), bem como a necessidade de uma análise profunda do caso concreto à luz de outros casos já decididos, a fim de que uma orientação - ainda que em linhas gerais e sujeita a desvios possa exsurgir.

\footnotetext{
${ }^{178}$ Grosso modo, a aplicação dos diferentes dispositivos é esclarecida no prefácio ao RUAA, no qual se lê: "The statute [RUAA] covers any commercial agreement to arbitrate and the resultant arbitration award unless the matter involves only American citizens and has no reasonable relationship to any foreign country and the courts have broadly applied the statute. Therefore, it is unlikely that state arbitration law will have major application to an international case. There are two instances where state arbitration law might apply in the international context: (1) where the parties designate a specific state arbitration law to govern the international arbitration and (2) where all parties to an arbitration proceeding involving an international transaction decide to proceed on a matter in state court and do not exercise their rights of removal under Chapter 2 of Title 9 and the relevant provision of state arbitration law is not preempted by federal arbitration law or the New York Convention. In these relatively rare cases, the state courts will refer to the RUAA unless the State has enacted a special international arbitration law." SAMUEL RosS LUTTRELL. Bias... op. cit., p. 146.

${ }^{179}$ CHARLES N. BROWER. The Ethics of arbitration: perspectives from a practicing international arbitrator, in Berkeley journal of international law publicist, v. 5, 2010, p. 14.

180 Texto disponível no endereço eletrônico http://www.leginfo.ca.gov/cgibin/displaycode? section=ccp\&group=01001-02000\&file=1297.121-1297.125; consulta em 21.02.2014.

${ }^{181}$ Por todos, CHARLES N. Brower. The Ethics... op. cit., pp. 15-19.
} 


\subsubsection{Tentativa de padronização via soft law: as IBA Guidelines on Conflicts of Interest in International Arbitration}

As International Bar Association Guidelines on Conflicts of Interest in International Arbitration (IBA Guidelines) têm como objetivo orientar o exercício do dever de revelação dos árbitros envolvidos em controvérsias de caráter internacional, individuando e clarificando os casos em que tal dever subsiste, e ensejando uniformidade de comportamento frente a situações similares, eliminando ou ao menos minimizando a disparidade de tratamento em eventos ligados à própria revelação, renúncia ao encargo e eventual impugnação.

As IBA Guidelines são resultado de mais de dois anos de pesquisa e desenvolvimento realizados por um Grupo de Trabalho composto de 19 membros nomeados pelo Committee on Arbitration and ADR da IBA. Seu título original era Guidelines on Impartiality, Independence and Disclosure in International Commercial Arbitration e, como o próprio nome sugeria, teria aplicação apenas no âmbito das arbitragens comerciais. No entanto, com a ampliação do escopo para qualquer tipo de arbitragem, as IBA Guidelines tiveram a denominação alterada para aquela ao final adotada ${ }^{182}$.

As IBA Guidelines não possuem eficácia jurídica vinculante para os ordenamentos nacionais, pondo-se, por isso, como corpo de regras que busca reconhecimento prático pela comunidade internacional. Nesse sentido, constitui uma soft law ${ }^{183}$, que não obstante o seu

\footnotetext{
${ }^{182}$ Sobre o trabalho de preparação das IBA Guidelines, vide OTO L. O DE WITT WIJNEN; NATHALIE VOSER; N. RAO. The background information on the IBA Guidelines on Conflicts of Interests in International Arbitration, in Business law international, v. 5, 2004, p. 433. Também sobre o tema, em análise de primeiramão, vide PHILlIP LANDOLT. The IBA Guidelines on Conflicts of Interest in International Arbitration: an overview, in Journal of international arbitration, v. 22, 2005, p. 409-418.

${ }^{183}$ Sobre os três sentidos principais do termo "soft law" (instrumento de caráter não vinculante; disposições formuladas de modo amplo ou abstrato; e regras cujo cumprimento não é passível de ser imposto por mecanismos vinculantes ou compulsórios de resolução de disputas), bem como sobre as três "portas de entrada" da soft law no processo arbitral (ferramenta persuasiva e inspiração para a prática de atos processuais; ferramenta eleita a priori como guia ou orientação para a prática de atos processuais; e aplicação como regra legal vinculante e obrigatória), vide ANDRÉ DE ALBUQUERQUE CAVALCANTI ABBUD. A soft law na arbitragem internacional: a obtenção de provas. Tese apresentada como requisito para a obtenção do título de Doutor em Direito Processual na Faculdade de Direito da USP, São Paulo, 2013, pp. 13 e 29-34.
} 
caráter não vinculante, têm sido objeto de referência de diversos e importantes precedentes judiciais de vários países ${ }^{184}$.

As IBA Guidelines são compostas de duas partes: a primeira de caráter geral e abstrato ("Princípios Gerais relativos a Imparcialidade, Independência e Divulgação"), e a segunda de tipo casuístico ("Aplicação prática dos Princípios Gerais", com as diferentes Listas) ${ }^{185}$.

A primeira parte afirma que o árbitro deve ser e permanecer imparcial e independente, desde o momento da sua indicação até a prolação da sentença arbitral (Princípio Geral 1). Quando um árbitro tiver dúvida a respeito da sua própria capacidade de permanecer imparcial ou independente, deve recusar o encargo (Princípio Geral 2); o mesmo princípio se aplica na hipótese em que possam surgir dúvidas justificadas a esse respeito. O texto especifica que dúvidas justificadas existem quando uma pessoa razoável e informada chega à conclusão de que há a possibilidade de que o árbitro possa ter sua decisão influenciada por outros fatores que não o mérito da causa apresentado pelas partes (Princípio Geral $2(c))^{186}$.

O árbitro deve, também, informar as partes, o tribunal arbitral e a instituição que administra o procedimento sobre qualquer circunstância que possa ensejar questionamento a respeito da sua imparcialidade ou independência aos olhos das partes (Princípio Geral 3). Eventual dúvida do árbitro a respeito da necessidade da revelação deve ser resolvida no sentido de fazê-la, o que não representa admissão de incompatibilidade do árbitro. No entanto, se o árbitro, à luz dessas revelações, considerar que não pode cumprir com o seu dever de imparcialidade, deve renunciar ao encargo (Princípio Geral 3(b)).

\footnotetext{
${ }^{184}$ Com referência detalhada a casos julgados entre 2004 e 2009, vide IBA CONFLICTS SUBCOMMITTEE. The IBA Guidelines of Conflicts of Interest in International Arbitration: The first five years 2004-2009, in Dispute resolution international, v. 4, n. 1, 2010, pp. 5-53.

185 O documento, em diferentes idiomas, pode ser acessado no endereço eletrônico http://www.ibanet.org/ENews_Archive/IBA_July_2008_ENews_ArbitrationMultipleLang.aspx; consulta em 21.02.2014.

${ }^{186}$ No original em língua inglesa: "a reasonable and informed third party would reach the conclusion that there was likelihood that the arbitrator may be influenced by factors other than the merits of the case as presented by the parties in reaching his or her decison".
} 
Com a eleição de padrões (denominados "Standards" na versão de língua inglesa e "Princípios Gerais" na versão em língua portuguesa), as IBA Guidelines buscam compreender a imparcialidade sobre diversos pontos de vista: subjetivamente pelo próprio árbitro, subjetivamente aos olhos das partes envolvidas, ou objetivamente por terceiro.

As IBA Guidelines também abrem espaço para a realidade em que é exercida a arbitragem internacional ao disporem sobre a relação entre árbitros e partes na perspectiva dos grandes grupos que operam na arbitragem internacional: as law firms (Princípio Geral 6(a)), os grupos de sociedades (Princípio Geral 6(b)) e as pessoas jurídicas (Princípio Geral 6.(c)).

$\mathrm{Na}$ defesa da tese de que é possível atingir-se maior consistência e menor quantidade de impugnações e renúncias de árbitros mediante detalhamento de casos específicos, o Grupo de Trabalho dotou as IBA Guidelines de uma segunda parte, nas quais são delineadas, de modo não exauriente e meramente exemplificativo, 49 circunstâncias concretas, divididas em 3 listas (denominadas "Application Lists" ou "Listas de Aplicação Prática") nas cores vermelha, laranja e verde.

A Lista Vermelha inclui as situações que podem redundar em dúvidas justificadas a respeito da imparcialidade ou independência do árbitro e que, por isso, devem ser sempre reveladas. Dessas, quatro situações são irrenunciáveis ("Lista Vermelha não Renunciável”) e, portanto, a sua ocorrência deve ensejar a recusa do árbitro à nomeação. Isso se verifica quando: $(i)$ existir identidade entre a parte e o árbitro; (ii) o árbitro for diretor de uma parte ou membro de um grupo de controle; (iii) o árbitro prestar assessoria regular à parte ou, ainda; (iv) houver interesse financeiro significativo do árbitro no êxito de uma das partes na disputa. A Lista Vermelha contém, além dos casos irrenunciáveis, um elenco de dezoito situações que, em abstrato, podem indicar parcialidade do árbitro, mas que podem ser objeto de renúncia das partes. É o caso, por exemplo, do árbitro que preventivamente elabora um parecer legal relativo a controvérsia, ou do árbitro que tem participação acionária em uma das partes, ou do árbitro que possua um familiar próximo com interesse no êxito de uma das partes, ou, ainda, quando tenha existido um contrato anterior entre o escritório do árbitro e uma das partes.

A Lista Laranja delineia um número de circunstâncias que podem levar a questionamentos sobre a imparcialidade aos olhos das partes e que, portanto, devem ser objeto de revelação. 
Constam, entre outros, os casos de nomeação repetida do árbitro pela mesma parte e de o árbitro ter desenvolvido a função de advogado contra uma das partes em uma questão não ligada ao objeto do processo arbitral. Há um limite temporal de três anos a partir do qual a situação deixa de ser importante, não precisando ser revelada. Em todos esses casos, considera-se que as partes aceitam o árbitro se, após a revelação, nenhuma delas apresentar impugnação tempestiva (trinta dias da revelação do árbitro ou de quando a parte toma conhecimento do motivo de um potencial conflito de interesse com o árbitro, conforme o Princípio Geral 4(a)).

Há diferenças procedimentais entre os casos da Lista Vermelha Renunciável e da Lista Laranja: para a Lista Laranja é necessária uma renúncia explícita (Princípio Geral 4(c)), para a Lista Vermelha Renunciável, entretanto, é admissível uma renúncia tácita quando não apresentada impugnação.

A Lista Verde, por fim, contém 18 hipóteses nas quais não existe conflito verdadeiro de interesses nem aparência a esse respeito que sejam relevantes do ponto de vista objetivo ou subjetivo. Disso resulta que, nessas situações, não há para o árbitro qualquer dever de revelação. Dita lista inclui, por exemplo, a hipótese em que o árbitro já tenha dado opinião, em sede científica, sobre uma questão que também é objeto do processo arbitral, mas que não se referia ao caso em disputa; a hipótese de que um advogado do escritório do árbitro tenha atuado contra uma das partes ou coligada, sem o envolvimento do árbitro; a hipótese de o árbitro ter relação com outro árbitro ou com o advogado de uma das partes por pertencerem a uma mesma associação profissional ou a uma mesma organização social; ou ainda a hipótese de o árbitro e o advogado de uma parte ou o outro árbitro terem trabalhado no mesmo painel em um processo arbitral precedente.

Embora sejam ao mesmo tempo bastante amplas e muito precisas, e com isso tenham recebido grande aceitação nas mais diversas jurisdições ${ }^{187}{ }^{188}$, as IBA Guidelines têm

\footnotetext{
${ }^{187}$ DAVID A. LAWSON. Impartiality and independence of international arbitrations. Commentary on the 2004 IBA Guidelines on Conflicts of Interest in International Arbitration, in ASA Bulletin, vol. 23, 2005, pp. $22 \mathrm{e}$ 55. MARKHAM BALL. Probity deconstructed: how helpful, really, are the new International Bar Association Guidelines on Conflicts of Interest in International Arbitration?, in Arbitration international, 2005, p. 323.

${ }^{188}$ Contra, com a afirmação de que as IBA Guidelines apenas fornecem uma ampla plataforma para novas táticas de impugnação de árbitros, V. V. VEEDER. The English Arbitration Act 1996: its 10th and future birthdays, disponível 
sofrido críticas que envolvem: (i) a falta de sistematização conceitual da primeira ${ }^{189}$ e da segunda partes ${ }^{190}$; (ii) a orientação demasiadamente pró-árbitro (que se revela, entre outras circunstâncias, no item 2.1.1, que torna renunciável a impugnação do árbitro que já tenha dado parecer a uma das partes sobre o conflito submetido à arbitragem) ${ }^{191}$; ou (iii) o tratamento diferente conferido a situações praticamente idênticas (que sobressai no cotejo entre os itens 1.4 e 2.3.7; o primeiro, constante da Lista Vermelha não Renunciável, compreende a situação em que o árbitro tenha prestado ou preste a uma das partes serviços em troca de pagamento substancial, enquanto o segundo, constante da Lista Laranja, compreende situação idêntica, sem fazer menção a pagamento) ${ }^{192}$.

A despeito do auxílio das IBA Guidelines na tentativa de oferecer mais luz sobre o tema e harmonizar, na medida do possível, a interpretação a respeito do padrão de análise da imparcialidade dos árbitros, é invencível a afirmação de que o texto - justamente por buscar as linhas gerais teoricamente aceitáveis nos mais diversos ordenamentos jurídicos não abre espaço para a expressão das diferentes experiências nacionais. As orientações do texto não podem, assim, ser seguidas sem séria ponderação a respeito de tais experiências que, conforme o caso, podem se revelar destoantes das orientações das IBA Guidelines ${ }^{193}$.

\subsubsection{Tratamento da imparcialidade nas instituições arbitrais}

As instituições empenhadas na prestação de serviços ligados à solução de controvérsias pelo método arbitral, conhecidas como "câmaras arbitrais" ou "centros de arbitragem", com interesse em aumentar a eficiência dos seus serviços (e assim evitar aumento dos

\footnotetext{
http://www.expertguides.com/default.asp?Page=10\&GuideID=150\&CountryID=117; $\quad$ consulta $\quad \mathrm{em}$ 21.02.2014.

${ }^{189}$ RAMON MULLERAT. Arbitrator's conflicts of interest revisited: a contribution to the revision of the excellent IBA Guidelines of Conflicts of Interest in International Arbitration, in Spain arbitration review, v. 14, 2012, p. 66.

${ }^{190}$ JAMES H CARTER. Reaching consensus on arbitrator conflicts: the way forward, in Dispute resolution international, v. 6, 2012, p. 27.

${ }^{191}$ RAMON MULlerat. Arbitrator's... op. cit., pp. 7.

${ }^{192}$ RAMON Mullerat. Arbitrator's... op. cit., pp. 6-7.

${ }^{193}$ Nesse sentido, a direta crítica de CARLOS Alberto CARMONA. Em torno do árbitro, in Revista de arbitragem e mediação, v. 28, 2011, p. 57.
} 
custos e desperdício de tempo com impugnações de árbitros, bem como manter um padrão de qualidade com a redução da possibilidade de ataques judiciais às sentenças arbitrais proferidas nos processos nelas conduzidos), também dispõem de regras e mecanismos para a promoção da imparcialidade do árbitro.

No âmbito internacional, o Regulamento de Arbitragem da Câmara de Arbitragem da Câmara de Comércio Internacional (CCI) demanda, em seu art. 11(1) que o árbitro seja e permaneça imparcial e independente frente às partes envolvidas na arbitragem. $\mathrm{O}$ árbitro deve, antes da sua nomeação pelo Secretário Geral ou pela Corte ${ }^{194}$ (art. 13.2), declarar por escrito sua independência, conforme art. 11(2). A falta de imparcialidade ou independência habilita a impugnação do árbitro, conforme art. 14(1), a ser decidida pela Corte, conforme art. 14(3). Além desses dispositivos, o art. 22(4) impõe ao tribunal arbitral a obrigação de conduzir o processo de modo justo e imparcial.

Ocupada em tornar mais claras as causas de impugnação dos árbitros, auxiliando na interpretação das disposições do seu Regulamento de Arbitragem, a CCI publicou, no ano de 2008, o extrato de decisões da Corte a respeito do tema ${ }^{195}$. Autor que se dedicou ao levantamento estatístico apontou que, entre janeiro de 2000 e dezembro de 2009, 345 impugnações a árbitros foram decididas pela Corte, em um total de 217 arbitragens. As impugnações atacaram 3,43\% do total de árbitros confirmados pela Corte (total de $10.061)^{196}$.

Outra instituição que administra processos arbitrais com renome internacional, a London Court of International Arbitration (LCIA), possui Regulamento de Arbitragem ${ }^{197}$ cujo art.

\footnotetext{
${ }^{194}$ A Corte é formada por mais de 100 profissionais dedicados à arbitragem internacional, oriundos de mais de 90 países, eleitos para mandato de 3 anos. Organização, funções e lista de membros podem ser consultadas no endereço eletrônico http://www.iccwbo.org/About-ICC/Organization/Dispute-Resolution-Services/ICCInternational-Court-of-Arbitration/; consulta em 21.02.2014.

195 ANNE MARIE WHITESELL. Independence in ICC arbitration: ICC Court practice concerning the appointment, comfirmation, challenge and replacement of arbitrators, in International Court of Arbitration Bulletin: 2007 Special Supplement - Independence of Arbitrators. Paris: ICC Publishing, 2008, pp. 7-40.

${ }^{196}$ KAREL DAELE. Challenge and disqualification of arbitrators in international arbitration. Netherlands: Kluwer Law International, 2012, p. 67. O autor tributa o baixo número de impugnações à técnica adotada no Regulamento da CCI, na qual, antes da confirmação pela Corte, as partes podem objetar a indicação de árbitro feita parte adversária, permitindo que o árbitro recuse a indicação ou que a Corte não confirme a sua nomeação, tudo sem iniciar o procedimento de impugnação.
}

197 ACIA Arbitration Rules, disponível no endereço eletrônico http://www.Icia.org/Dispute_Resolution_Services/LCIA_Arbitration_Rules.aspx; consulta em 21.02.2014. 
5.2 determina que o árbitro deve ser e permanecer imparcial e independente frente às partes, agregando que o árbitro não deve agir como advogado de qualquer delas. Referido Regulamento também prescreve, ao lado de outros motivos para o afastamento do árbitro (não atuar de modo justo e imparcial frente às partes ou não conduzir ou participar do processo com a razoável diligência; art. 10.2), que o árbitro pode ser impugnado por qualquer das partes se houver circunstâncias que levantem dúvidas justificadas sobre sua imparcialidade ou independência; a parte pode até mesmo impugnar o árbitro que havia nomeado se tomar conhecimento dessas razões após ter realizado a indicação (art. 10.3) ${ }^{198}$. As impugnações são decididas pela Corte ${ }^{199}$.

Assim como a CCI, a LCIA tornou públicos extratos de decisões a respeito da impugnação de árbitros em $2011^{200}$. Entre janeiro de 2006 e dezembro de 2010, 30 impugnações foram apresentadas frente a um total de 986 casos iniciados no mesmo período ${ }^{201}$.

Em termos de publicidade, notórias são as decisões proferidas nas arbitragens de investimento reguladas pela Convenção para a Resolução de Disputas Relativas a Investimentos Entre Estados e Nacionais de Outros Estados (ICSID) ${ }^{202}$, tanto no que diz respeito à impugnação e afastamento de árbitros (arts. 57 e 58) quanto no que diz respeito à anulação das sentenças, cuja decisão é dada por uma comissão $a d$ hoc formada por árbitros escolhidos pelo Presidente do Banco Mundial com apoio no respectivo secretariado da instituição (ICSID) entre os integrantes de uma lista fornecida pelos países signatários da convenção (arts. 50 a 52) ${ }^{203}$. A divulgação dessas decisões permite a análise do

\footnotetext{
${ }^{198}$ No original: "An arbitrator may also be challenged by any party if circumstances exist that give rise to justifiable doubts as to his impartiality or independence. A party may challenge an arbitrator it has nominated, or in whose appointment it has participated, only for reasons of which it becomes aware after the appointment has been made."

${ }^{199}$ A Corte é formada por 35 arbitralistas oriundos das maiores áreas comerciais do mundo, dos quais não mais que 6 podem ser nacionais do Reino Unido. Maiores informações sobre a composição da instituição podem ser obtidas no endereço eletrônico http://www.lcia.org/LCIA/Organisation.aspx; consulta em 21.02.2014.

${ }^{200}$ Ruth Teitelbaum; Thomas W. WaLSH. The LCIA Court decisions on challenges to arbitrators: an introduction, in Arbitration international, v. 27, pp. 283-313.

${ }^{201}$ KAREL DAele. Challenge... op. cit., p. 67.

${ }^{202}$ Disponível no endereço eletrônico https://icsid.worldbank.org/ICSID/StaticFiles/basicdoc/CRR Englishfinal.pdf; consulta em 21.02.2014.

${ }^{203}$ Comentários sobre o sistema de anulação e críticas ao "movimento pendular" de evolução das decisões anulatórias são feito por JOSÉ MIGUEL JÚDICE; TIAGO DUARTE. A anulação de sentenças ICSID: corrigir as sentenças ou corrigir as tendências?, in SELMA FERREIRA LEMES; INEZ BALBINO (Ed.). Arbitragem: temas contemporâneos. São Paulo: Quartier Latin, 2012, pp. 327-357.
} 
entendimento a respeito do requisito trazido pelo art. 14(1), que impõe que o árbitro inspire confiança sobre sua imparcialidade. Interessante notar que, na versão em língua inglesa da Convenção, o texto descreve que o árbitro "may be relied upon to exercise independent judgment", ao passo que a versão em língua espanhola descreve que ele deve "inspirar plena confianza en su imparcialidad de juicio", enquanto a versão em língua francesa, que ele deve "offrir toute garantie d'indépendance dans l'exercice de leurs fonctions". Não importando a expressão utilizada, o que se verá no presente estudo ${ }^{204}$ é que a análise das impugnações e pedidos de anulação de sentença, nos casos ICSID, sempre envolve a imparcialidade dos árbitros.

No Brasil, as principais câmaras e centros de arbitragem também possuem dispositivos regulamentares voltados à proteção da imparcialidade dos árbitros. É o que ocorre no Centro de Arbitragem e Mediação da Câmara de Comércio Brasil-Canadá (CAM-CCBC), cujo Regulamento prevê as causas pelas quais o árbitro não pode ser nomeado ou possa ser impugnado, em artigo que reproduz as hipóteses previstas no Código de Processo Civil sobre impedimento e suspeição do juiz, além de estabelecer outras ${ }^{205}$. O CAM-CCBC possui, ainda, um Código de Ética para os árbitros, que impõe ao árbitro o dever de ser e permanecer independente e imparcial, além do dever de revelação de qualquer fato ou circunstância que possa dar origem a dúvidas quanto à sua imparcialidade e independência, não apenas no seu sentir, mas também segundo os olhos das partes ${ }^{206}$. Modelo sutilmente diferente é o adotado pela Câmara de Conciliação, Mediação e Arbitragem Ciesp/Fiesp (CCMA-CIESP/FIESP), cujo Regulamento prevê, no seu art. 7.3, a possibilidade de serem arguídos o impedimento ou a suspeição do árbitro, bem como impõe que, no desempenho de sua função, o árbitro se mantenha independente e imparcial ${ }^{207}$. A CCMA-CIESP/FIESP também possui Código de Ética, o qual impõe ao árbitro o dever de manter-se imparcial e independente, sendo expresso que, para conservar-se imparcial, o árbitro deve atuar

\footnotetext{
${ }^{204}$ A análise de casos é feita no capítulo 4.2 do presente estudo.

${ }^{205}$ Entre elas, as previstas nas letras "k" e "l" do art. 5.2, que dispõem, respectivamente, as hipóteses de o árbitro "ter atuado como mediador ou conciliador, na controvérsia, antes da instituição da arbitragem, salvo expressa concordância das partes" e "tenha interesse econômico relacionado com qualquer das partes ou seus advogados, salvo por expressa concordância das mesmas." Íntegra do regulamento está disponível no endereço eletrônico http://www.ccbc.org.br/default.asp?categoria=2\&subcategoria=Regulamento 2012\#5; consulta em 21.02.2014.

206 Disponível no endereço eletrônico http://www.ccbc.org.br/default.asp?categoria=2\&subcategoria=codigodeetica; consulta em 21.02.2014.

207 Disponível no endereço eletrônico http://www.camaradearbitragemsp.com.br/index.php/ptBR/regulamento/4-principal/principal/127-regulamento-de-arbitragem-2013; consulta em 21.02.2014.
} 
"formando sua livre convicção com base na prova produzida no processo" e que, para conservar a independência "o árbitro não deve manter vínculo com quaisquer das partes 208 . O Centro de Arbitragem da Câmara Americana de Comércio (CA-AMCHAM) que, diferentemente das instituições anteriores, não possui uma lista de árbitros, tem Regulamento cujo art. 3.2 prevê o dever de independência e imparcialidade do árbitro, detalhando que será considerada fundada a suspeição de parcialidade do árbitro em cinco hipóteses expressas, inspiradas nas hipóteses de suspeição dos juízes, "entre outras"209. Também o Regulamento da Câmara de Arbitragem Empresarial-Brasil (CAMARB) estabelece, no seu art. 4.3, sete hipóteses de impugnação do árbitro, sendo a mais ampla a que permite a impugnação caso o árbitro "não tenha independência, imparcialidade para conduzir a arbitragem ou julgar o litígio" ${ }^{210}$. O Centro Brasileiro de Mediação e Arbitragem (CBMA) possui regulamento que impõe, no seu art. 5.3, que o árbitro "deverá ser e permanecer independente e imparcial", prevendo a possibilidade de sua recusa pela parte em razão da ausência dessas qualidades, consoante art. 7.1, sem se deter em mais detalhes ou hipóteses que configurariam a falta de imparcialidade ou de independência. $\mathrm{O}$ item VII.3 do Código de Ética da instituição comanda ao árbitro "[d]ecidir com imparcialidade e independência", bem como, no item V.4 "[r]evelar qualquer interesse ou relacionamento que provavelmente afete a independência ou que possa criar uma aparência de parcialidade ou tendência" ${ }^{\text {211. }}$.

\subsection{Disposições sobre imparcialidade do árbitro na lei e a doutrina brasileira: observações críticas}

Mesmo antes da promulgação da LA, trabalhos doutrinários pioneiros na área trataram o tema da imparcialidade do árbitro à luz do CPC, apontando que "o Código assemelha o árbitro ao juiz nas hipóteses de impedimento e suspeição legal, sem considerar as

208 Disponível no endereço eletrônico http://www.camaradearbitragemsp.com.br/index.php/ptBR/regulamento/4-principal/principal/130-codigo-de-etica; consulta em 21.02.2014.

209 Disponível no endereço eletrônico http://www.amcham.com.br/repositorio-dearquivos/Regulamentoago_2013.pdf; consulta em 21.02.2014.

${ }^{210}$ Disponível no endereço eletrônico http://camarb.com.br/regulamento/; consulta em 21.02.2014.

211 Regulamento disponível no eletrônico http://site1379424603.hospedagemdesites.ws/regulamento_1; consulta em 21.02.2014. Código de Ética disponível no endereço eletrônico http://cbma.com.br/codigo_de etica; consulta em 21.02.2014. 
características diversas de cada um" ${ }^{212}$. Dado o regramento então existente, parte da escassa doutrina sugeria que tais hipóteses prevaleceriam mesmo se as partes conhecessem e anuíssem com a atuação de árbitros envolvidos em eventos previstos no $\mathrm{CPC}^{213}$, enquanto outra corrente afirmava textualmente que, com exceção da causa prevista no art. 134, inc I, do CPC, todas as demais causas de impedimento e suspeição poderiam ser de comum acordo afastadas pelas partes ${ }^{214} 215$.

Com a entrada em vigor da LA, o tema da imparcialidade do árbitro passa a ser disposto no art. 13, que esclarece que essa função será exercida por pessoa capaz que tenha a confiança das partes.

A despeito das tentativas da doutrina brasileira em ligar a confiança das partes à imparcialidade (como se verá a seguir neste capítulo), o presente estudo defende que a confiança requerida pelo dispositivo liga-se à contratação do árbitro, e não ao exercício do seu poder jurisdicional. Em outras palavras, ela se refere à relação contratual entre partes e árbitro, e não à relação processual, pois, para a prestação do serviço ${ }^{216}$ de solucionar a controvérsia, o árbitro - tal como qualquer contratado - deve gozar da confiança dos que os contratam, ao passo que seu poder jurisdicional não encontra qualquer amparo na confiança, derivando da eficácia que a lei confere à investidura do árbitro.

É evidente que essa investidura apenas se dá enquanto vigente o contrato entre partes e árbitro, e é por isso que as partes, em conjunto (e salvo disposição em sentido contrário),

\footnotetext{
${ }^{212}$ José CaRlos de Magalhães; LuIZ Olavo BaPtista. Arbitragem comercial. Rio de Janeiro: Freitas Bastos, 1986, pp. 28-29.

${ }^{213}$ José CARLos De Magalhães; Luiz Olavo BaPtista. Arbitragem... op. cit., p. 29.

${ }^{214}$ Carlos Alberto Carmona. A arbitragem no Código de Processo Civil Brasileiro. Tese apresentada como requisito para a obtenção do título de Doutor em Direito Processual na Faculdade de Direito da USP, São Paulo, 1990, p. 106.

${ }^{215}$ Entre os trabalhos pioneiros, o de Guerreiro faz apenas breve menção à neutralidade (cultural) do árbitro, sem adentrar no tema da imparcialidade, ao passo que o de Leães não trata desses assuntos. Vide JosÉ ALEXANDRE TAVARES GUERREIRO. Fundamentos da arbitragem comercial internacional. Tese apresentada como requisito para a obtenção do título de Doutor em Direito Processual na Faculdade de Direito da USP, São Paulo, 1989, pp. 270-272 e LUIZ GASTÃo PAES DE BARROS LEÃES. Ensaio sôbre arbitragens comerciais, São Paulo: RT, 1966.

${ }^{216}$ A exata qualificação da relação contratual entre árbitro e partes foge do escopo do presente estudo. Sobre o tema e as obrigações derivadas do contrato, vide AgOSTINHO PEREIRA MIRANDA. O estatuto deontológico do árbitro: passado, presente e futuro, in III Congresso do Centro de Arbitragem da Câmara de Comércio e Indústria. Coimbra: Almedina, 2010, p. 62. Análise aprofundada da relação jurídica contratual é feita por VALERIO SANGIOVANNI. Il rapporto... op. cit., pp. 827-837.
} 
podem, de comum acordo, denunciar ou resilir o contrato com o árbitro se nele não mais confiarem. No entanto, se uma das partes não mais confiar no árbitro, ela não pode sozinha e exclusivamente com base na perda subjetiva da confiança - resolver o contrato com o árbitro. Assim, não é a mera perda da confiança a hipótese que desencadeia uma consequência jurídica, mas o ato de vontade de ambas as partes.

As colocações a respeito da confiança ficarão mais claras na medida em que a análise introduzir também o dever de imparcialidade do árbitro, que está inscrito, ao lado dos deveres de independência, competência, diligência e discrição, no $\S 6^{\circ}$ do art. 13 da LA.

Em análise ao referido dispositivo, há na doutrina quem não atribua qualquer autonomia aos termos "independência" e "imparcialidade", a ponto de afirmar que "uma condição pressupõe a outra: um árbitro dependente não é imparcial; para ser imparcial, não pode ser dependente" ${ }^{217}$. No entanto, a maioria dos autores brasileiros, acompanhando a doutrina estrangeira, busca diferenciar independência da imparcialidade com base no binômio objetividade-subjetividade, afirmando que a "independência se fundamenta em critérios objetivos de verificação, e, por sua vez, a imparcialidade está vinculada a critérios subjetivos, que, na prática, são de difícil aferição, já que externam um estado de espírito (state of mind)",218.

Ao buscar um desenvolvimento para essas noções gerais que permitisse a operação de casos concretos, a doutrina passa a qualificar de independente "o árbitro que não está ligado por algum vínculo próximo ou pessoal com uma das partes, e tampouco se prende a interesses no objeto do conflito" ${ }^{, 19}$, o que evidentemente colabora para a sobreposição conceitual, visto que, segundo o binômio original, o interesse pessoal pela causa estaria compreendido na noção geral de imparcialidade, não na noção de independência.

\footnotetext{
${ }^{217}$ José EDUARDo CARREIRA AlVIM. Tratado geral da arbitragem. Belo Horizonte: Mandamentos: 2000, p. 312.

${ }^{218}$ SELMA MARIA FERREIRA LEMES. Árbitro: princípios da independência e imparcialidade. São Paulo: LTr: 2001, p. 53. No mesmo sentido, Luiz Olavo BAPTISTA. Arbitragem comercial e internacional, São Paulo: Lex Magister, 2011, p. 165.

${ }^{219}$ Pedro A. BAtista MARTins. Apontamentos sobre a lei de arbitragem. Rio de Janeiro: Forense, 2008, p. 188.
} 
Se a independência - que se prega objetiva - acaba por ser subjetivada, também é possível assistir às tentativas de objetivação da imparcialidade - que se prega subjetiva. Assim ocorre ao se afirmar que "[a] primeira qualidade que se exige do árbitro é a imparcialidade, ou seja, a equidistância que o julgador deve guardar em relação às partes" 220 ou que "[o conceito de imparcialidade] diz respeito à necessidade de não estar o julgador envolvido diretamente com os litigantes" ${ }^{221}$. A equidistância, tomada no trecho em sentido figurado, é conceito demasiado fluido e impreciso para caracterizar a imparcialidade, visto que não deixa claro em relação a quê seria aplicável. Seria equidistância em atos ou em pensamento? Se for em atos, o árbitro pode ser equidistante nos atos processuais e ainda assim ser parcial, bastando pensar na hipótese de ele tratar as partes desigualmente no curso do processo arbitral, beneficiando a parte contra a qual tem tendenciosidade, justamente para encobrir sua parcialidade. Se for em pensamento, a expressão perde totalmente a sua utilidade por duas razões: (i) ninguém é equidistante em relação a duas pessoas ou teses, tendo todas as pessoas (inclusive os julgadores) suas inevitáveis preferências originais; e (ii) como a equidistância poderia ser detectada a partir da conduta ou da situação do árbitro em relação a uma das partes, qualquer contato ou a mais singela diferença de conduta poderia levar à conclusão da perda de equidistância, permitindo a impugnação do árbitro e trazendo a instabilidade generalizada para o exercício da função.

Por sua vez, dizer-se que o árbitro não deve "estar (...) envolvido diretamente com os litigantes" é reconduzir o conceito de imparcialidade ao de independência e descartar a possibilidade de o árbitro ser parcial ainda que não envolvido com as partes litigantes, bastando pensar em um árbitro que defende, em outro procedimento no qual atua como advogado, alegações de direito idênticas e alegações de fato análogas às que lhe foram apresentadas no processo em que é árbitro. Não há qualquer envolvimento direto, mas a parcialidade pode ser constatada.

Para alcançar um conteúdo mais operativo aos termos, parte da doutrina divide a imparcialidade em dois aspectos: o subjetivo, "no sentido de que não deve possuir interesses próprios na solução do litígio"; e o objetivo, "quando [a lei] exige que o

\footnotetext{
${ }^{220}$ Carlos Alberto Carmona. Arbitragem... op. cit., p. 239.

${ }^{221}$ Carlos Alberto Carmona. Arbitragem... op. cit., p. 240.
} 
julgador, no caso, o árbitro, conduza o processo arbitral de forma isonômica, garantindo às partes as mesmas 'armas, "222. A divisão não parece adequada, pois o tratamento isonômico diz respeito direto à proteção da igualdade das partes ou ao contraditório no processo arbitral, problemas também enquadrados no art. $21, \S 2^{\circ}$, da LA, podendo ou não ter como causa ou origem a parcialidade do árbitro. Imagine-se o caso de o árbitro enviar a uma parte uma ordem processual a respeito da produção de prova e, para a outra parte, uma versão anterior e divergente do documento (ou então, que o documento jamais chegue a ela) e que cada parte cumpra aquilo que estava determinado na ordem processual que recebeu, resultando em desvantagem para uma delas. Esse tratamento desigual, refletindo na sentença, ensejará a sua anulação independentemente de o árbitro ser ou não parcial. Ademais, no limite, a garantia das mesmas armas poderia levar à acusação de parcialidade do árbitro que, percebendo a desvantagem de uma parte sem patrocínio frente a outra, patrocinada por excelente escritório de advocacia, não reequilibrasse de algum modo a relação processual, ou ao árbitro que não aceitasse o pedido de gratuidade da parte que não pudesse arcar com os custos da arbitragem. Esse é risco do qual a prática da arbitragem pode prescindir.

Ademais, a despeito da objetividade com que a doutrina afirma tratar a independência, não é raro deparar-se com afirmações tais como " a independência do árbitro deve ser aferida com vistas à confiança que ele suscita nas partes, e não no grau de confiabilidade que ele próprio acredita possuir",223, que se utilizam do elemento "confiança das partes" (que nada tem a ver com imparcialidade ou com independência) para subjetivar o que, segundo o binômio já tratado, deveria ser objetivo. Não se pode negar que a escolha de um árbitro seja informada - entre outros atributos - pela confiança que tal sujeito enseja no espírito de quem o escolheu. Essa confiança, no entanto, não tem qualquer repercussão normativa na configuração da independência ou da imparcialidade. É possível que uma ou ambas as partes confiem no árbitro, ainda que ele se enquadre em uma das relações previstas no art. 14 da LA, e se decidam por não apresentar requerimento para seu afastamento, deixando assim de exercer a faculdade que a lei lhes outorga. Essa possibilidade, entretanto, não atribui à confiança - tomada em si, e não como causa de um comportamento das partes em

\footnotetext{
${ }^{222}$ FERNANDO SiLVA MOREIRA DOS SANTOS. Impedimento e suspeição do árbitro: o dever de revelação, in Revista de arbitragem e mediação, v. 35, 2012, p. 45.

${ }^{223}$ MARCELO ROBERTO FerRo. Apontamentos sobre a independência dos árbitros, in MARCELO VIEIRA VON ADAMEK (Ed.). Temas de direito societário e empresarial contemporâneos. São Paulo: Malheiros, 2011, p. 858.
} 
exercer ou não uma faculdade - qualquer eficácia normativa, visto que nenhuma sanção processual é cominada à desconfiança. Assim, a imparcialidade e a independência não podem se relacionar com a confiança das partes, sob pena de se desestabilizar a relação processual toda vez que a parte desgostar e alterar sua impressão subjetiva a respeito do árbitro $^{224}$; daí falar-se em impugnações e recusas infundadas ${ }^{225}$. Se ambas as partes estiverem insatisfeitas com o árbitro, podem, se assim permitirem as regras às quais se vincularam, substituí-lo por conta da relação contratual que mantêm com o julgador. Aqui, mais uma vez, não é atribuída eficácia jurídica direta à confiança, que nada mais é que a causa remota para um comportamento (denúncia ou resilição do contrato de arbitragem) das partes.

Ao não conceituar a imparcialidade e a independência, mas impô-las ao árbitro, a LA não apenas abre espaço à confusão conceitual como também permite a interpretação de que ambos os deveres teriam a mesma envergadura e importância na arbitragem, ou então que "[a] independência está instrinsecamente ligada à imparcialidade. Para ser imparcial deve necessariamente se pressupor que é independente"226. No entanto, o que ocorreria se as partes declarassem que não teriam nada a opor a um árbitro que se declare dependente de uma delas? Essa dependência admitiria graus (como se veria na hipótese de o árbitro ser investidor de algumas centenas de reais em fundo de investimento que detém, entre outras, ações de companhia coligada a uma das partes, em comparação com a hipótese de o árbitro ser o sócio majoritário dessa companhia)? Esse ato inviabilizaria a ulterior invalidação da sentença arbitral? Seria diferente se o árbitro se declarasse parcial (não dependente) em favor de uma das partes? Em resposta a essa última pergunta, parte da doutrina situa a imparcialidade na esfera da autonomia privada, sugerindo que seria permitido que até mesmo um árbitro declaradamente parcial atuasse no caso e tivesse sua sentença imunizada se as partes, sabedoras da parcialidade declarada, dissessem que nada têm a opor: é a leitura que se pode fazer da afirmação de que "a imparcialidade do árbitro, entendida como a eqüidistância do julgador em relação às partes, está no campo da autonomia privada no direito brasileiro. Assim, é possível, por exemplo, que até mesmo um parente

\footnotetext{
${ }^{224}$ Contra, buscando ligar a confiança "fiducial" (objetivada pela lei) aos casos de impedimento e suspeição dos árbitros, TÉRCIO SAMPAIO FERRAZ JÚNIOR. Suspeição e impedimento na arbitragem: sobre o dever de revelar na Lei 9.307/1996, in Revista de arbitragem e mediação, v. 28, 2011, pp. 71-75.

${ }^{225}$ José EMILIO NunEs PINTO. Recusa e impugnação de árbitro, in Revista de arbitragem e mediação, v. 15, 2007, p. 83

${ }^{226}$ FERNANDO SILVA MOREIRA DOS SANTOS. Impedimento... op. cit., p. 48.
} 
de uma das partes seja árbitro no conflito existente entre elas, desde que presente o binômio ciência-anuência",227 ou à afirmação de que "a imparcialidade do árbitro, ao contrário do que ocorre no processo judicial, não integra o devido processo legal no direito brasileiro e não é, por conseguinte, questão de ordem pública, estando restrita realmente ao campo da autonomia privada"228.

O presente estudo toma direção diversa, defendendo que um julgador não pode ser parcial, pois a parcialidade - que não admite gradação - tornaria inútil o próprio processo, visto que o convencimento do julgador não derivaria da influência que, nele, as partes poderiam exercer $^{229}$.

Além da mistura entre confiança, independência e imparcialidade, é possível perceber que, para essa última, a lei brasileira não oferece, como fazem algumas de suas similares estrangeiras ao positivarem as "justifiable doubts" como suporte para a impugnação do árbitro, sequer a indicação sobre como aferi-la no caso concreto. A única tentativa da LA em estabelecer que "estão impedidos de funcionar como árbitros as pessoas, com as partes ou com o litígio, algumas das relações que caracterizam os casos de impedimento ou suspeição de juízes" causa mais dúvidas. Não há qualquer indicação de quais seriam tais "algumas" relações nem como elas "caracterizariam" os casos de impedimento ou suspeição de juízes. Há, no art. 134 do Código de Processo Civil, seis hipóteses de impedimento, e no art. 135, cinco hipóteses de suspeição; dentre todas essas relações identificadas per relationem, quais seriam as algumas que o art. 14 da LA, aparentemente, exclui? Não há indicação, ainda, se essas algumas relações exauririam, para o direito

\footnotetext{
${ }^{227}$ RAFAEL FRANCISCO ALVES. A imparcialidade do árbitro no direito brasileiro: autonomia privada ou devido processo legal?, in Revista de arbitragem e mediação, n. 7, 2005, p. 121.

${ }^{228}$ RAFAEl FranCISCO AlVES. A imparcialidade... op. cit., p. 122.

${ }^{229}$ O tema será tratado com mais profundidade no capítulo 2.2 do presente estudo.
} 
brasileiro, todas as hipóteses de ausência de imparcialidade ou independência do árbitro ${ }^{230}$ ou se outras haveria, ainda que não redutíveis às previsões do Código de Processo Civill ${ }^{231}$.

Desse modo, é preciso reconhecer um conteúdo mais preciso que uma vaga noção geral de imparcialidade; um conteúdo que exclua a análise subjetiva do árbitro e que se prenda àquilo que pode ser, o tanto quanto possível, demonstrável.

Mais que um conteúdo, é preciso estabelecer um método que auxilie a sua aplicação frente às infinitas variáveis que se podem fazer presentes na vida prática. De fato, de nada vale a identificação de um conteúdo conceitual não aplicável aos casos concretos, assim como de nada vale o estudo de casos se entre eles não houver elementos que os amalgame sob um conteúdo operativo. Superar essa dificuldade é o que o presente estudo busca fazer no capítulo seguinte.

\footnotetext{
${ }^{230}$ Assim: "Tal como faz o Código de Processo Civil ('CPC') em relação aos juízes, a LdA estabelece os casos de impedimento (e suspeição) do árbitro como 'numerus clausus' ". LuIZ Olavo BAPTISTA. Inutilidades e futilidade daninha: a questão das impugnações de árbitro descabidas, in Revista direito ao ponto, ano 6 , n. 8,2013 , p. 28 . No mesmo sentido: "O que não significa que os casos de impedimento (impedimento e suspeição) na Lei de Arbitragem sejam exemplificativos e abertos. Ou seja, as partes, por força da confiança (fiducial) podem relevar razões não só de suspeição como de impedimento e aceitar árbitros apesar de seu enquadramento no rol taxativo do Código de Processo Civil, mas não podem criar outros motivos, quer para suspeição quer para impedimento, fora da lista taxativa do CPC." TÉRCIO SAMPAIO FERRAZ JÚNIOR. Suspeição... op. cit., p. 75.

${ }^{231}$ Carlos Alberto Carmona. Arbitragem... op. cit., p. 253.
} 


\section{CAPÍTULO 2. CONTEÚDO DA IMPARCIALIDADE DO ÁRBITRO E SUA OPERACIONALIZAÇÃO PELA APARÊNCIA}

\subsection{Função da imparcialidade}

É inegável a importância da imparcialidade do árbitro para além da esfera estritamente processual. As entidades que administram processos arbitrais, os profissionais que prestam serviços como árbitros, os sujeitos que efetiva ou potencialmente recorrem à arbitragem para a solução de suas controvérsias, e até mesmo o Estado têm interesses não imediatamente ligados ao processo arbitral, mas que tocam o tema da imparcialidade do árbitro: as instituições de arbitragem buscam sucesso comercial que advém, sobretudo, da qualidade dos serviços que prestam e da qualidade do regulamento (que entre outros temas relevantes para a higidez do processo, tratam da imparcialidade do árbitro) ${ }^{232}$; os profissionais que prestam serviços como árbitros, igualmente, possuem interesses comerciais, profissionais e mesmo pessoais em se destacarem no ofício, consideração que decorre, dentre outras causas, da reputação (que inclui a atuação com imparcialidade) que conseguem conquistar ${ }^{233}$; os sujeitos que submetem suas disputas ao método arbitral têm interesse na adequada solução das suas controvérsias, possibilitada, entre outras razões, pela imparcialidade do julgador ${ }^{234}$; e o Estado, na medida em que estabelece o ambiente institucional da arbitragem (pela lei e por decisões judiciais), tem interesse em fazer respeitar suas diretrizes ${ }^{235}$.

Nos casos concretos, a relevância da imparcialidade é sentida antes mesmo da instauração do processo arbitral: o profissional indicado para o posto de árbitro tem o dever de prestar

\footnotetext{
${ }^{232}$ Sobre as percepções dos profissionais atuantes no ramo da arbitragem no Brasil, vide ANDRÉ DE AlbuQuerque CaVAlCANTI ABbud. Relatório "Arbitragem no Brasil - Pesquisa CBAr-IPsos", 2012, p. 22, disponível no endereço eletrônico http://www.cbar.org.br/PDF/Pesquisa_CBAr-Ipsos-final.pdf; consulta em 21.02.2014.

${ }^{233}$ AndRÉ DE AlbuQuerque CAVALCANTI ABbud. Relatório... op. cit., p. 22.

${ }^{234}$ ANDRÉ DE AlbuQuerque CAVAlCANTI ABBud. Relatório... op. cit., pp. 11-13.

${ }^{235}$ Extenso exame da resposta de várias legislações ao aumento do uso - e dos valores envolvidos - nas arbitragens internacionais é apresentado por THOMAS E. CARBONNEAU. The ballad of transnational arbitration, in University of Miami law review, v. 56, n. 4, 2002, pp. 781-792.
} 
revelações, dentre outros, dos fatos que podem gerar dúvidas sobre a sua imparcialidade ${ }^{236}$, dever que orbita a relação contratual estabelecida entre o profissional e as partes (com ou sem a intermediação da instituição arbitral) ${ }^{237}$, e não a relação processual, pois tal dever existe antes e independentemente do processo (imagine-se o caso de o profissional indicado, após a revelação, não ser aceito como árbitro e sequer assumir o encargo; nesse caso, há o procedimento, mas não o processo, nos termos do art. 19 da LA).

Apesar de sua importância extrapolar o processo arbitral e se revelar antes da sua instauração, é nele que a imparcialidade serve à sua função de integração do due process ${ }^{238}$ que, investigada, permite estabelecer premissas para a superação da noção genérica que dificulta a sua identificação nos casos concretos.

\subsubsection{Modelo processual, participação e influência}

Teorias sobre a legitimação das decisões jurisdicionais ${ }^{239} 240$ e sobre o exercício da democracia através do discurso influenciaram a concepção ${ }^{241}$ do "modelo democrático de processo", que põe em relevo a participação do julgador e das partes para o seu desenvolvimento e conclusão ${ }^{242}$.

Considerando-se a abertura do sistema jurídico ao entorno social e à pluralidade de valores e interesses - conflitantes - que ele contém, resta cada vez mais comprometida a eficácia

\footnotetext{
${ }^{236}$ A distinção entre o dever de revelação e a imparcialidade é tratada no capítulo 4.3 do presente estudo.

${ }^{237}$ Sobre a relação contratual entre árbitros, partes e instituição arbitral, vide VALERIO SANGIOVANNI. Il rapporto... op. cit., pp. 827-837. Vide, também MANUEL PEREIRA BARROCAS. Manual de arbitragem. Coimbra: Almedina, 2010, pp. 319-325.

${ }^{238}$ Sobre o devido processo na arbitragem, vide EdUARDo DE ALBUQUERQUE PARENTE. Processo... op. cit., pp. 103-107. Vide, também, MATTI S. KURKela; SANTTU TURUNEn. Due process... op. cit., pp. 1-14.

${ }^{239}$ ANDRÉ AlVes De ALMEIDA. Processualidade jurídica e legitimidade normativa. Belo Horizonte: Fórum, 2005, p. 110.

${ }^{240} \mathrm{Na}$ verdade, as teorias se voltam à legitimação e controle de todas as instâncias do poder estatal, e não apenas do poder jurisdicional. Sobre o tema, ANTONiO MANUel PeÑa Freire. La garantía en el estado constitucional de derecho. Madrid: Trotta, 1997, passim.

${ }^{241}$ Antonio do Passo CABRAL. Nulidades do processo moderno. 2. ed. Rio de Janeiro: Forense, 2010, p. 106.

${ }^{242}$ Dierle José Coelho Nunes. Processo jurisdicional democrático: uma análise crítica das reformas processuais. Curitiba: Juruá, 2008, p. 212.
} 
da lei (elaborações políticas de interesse geral) para a solução de controvérsias. Tal solução, assim, deve ser construída de acordo com a dinamicidade e pluralidade sociais, através de pressupostos comunicativos que letigimam o direito produzido pelo diálogo ${ }^{243}$, que utiliza como ponto de partida as homogenizações normativas características das regulações legais (embora não se esgote nelas) ${ }^{244}$. Ao assim proceder, abre-se espaço às considerações específicas dos valores, interesses e bens jurídicos envolvidos, legitimando o exercício do poder não apenas pela autoridade da lei (cuja importância é indiscutível), mas pela consideração e participação dos seus destinatários na construção da norma vigente e aplicável à solução da controvérsia ${ }^{245}$.

Por sua vez, as teorias do discurso buscam reconhecer as condições pelas quais uma decisão pode ser racionalmente obtida, mediante um processo comunicativo voltado ao consenso $^{246}$. Entre tais condições está a oportunidade de os debatedores participarem seriamente da argumentação, em completa igualdade de oportunidades ${ }^{247}$.

Inspirada por essas ideias, a processualística moderna substituiu não apenas o ideário liberal do processo como coisa das partes meramente fiscalizada pelo julgador, como também ultrapassou o ideário social e ativista do processo como coisa do julgador ao qual as partes se submetem ${ }^{248}$. Esses padrões foram suplantados pelo modelo democrático de processo $^{249}$, que exige a comparticipação de todos os sujeitos processuais ${ }^{250}$, agregando ao conteúdo do contraditório processual não apenas a possibilidade de as partes se informarem sobre (ou se oporem a) uma decisão, mas a possibilidade de que elas - efetiva

243 JÜRGEN HABERMAS. Direito e democracia: entre facticidade e validade (trad. Flávio Beno Siebeneichler), v. II, 2. ed. Rio de Janeiro: Tempo Brasileiro, 2003, pp. 19-25.

${ }^{244}$ ANTONIO MANUEL PEÑA FREIRE. La garantía... op. cit., pp. 246-247.

${ }^{245}$ Rosemiro PEREIRA LEAL. Teoria processual da decisão jurídica. São Paulo: Landy, 2002, p. 145.

${ }^{246}$ ANTONIO DO PASSO CABRAL. Nulidades... op. cit., p. 109.

${ }^{247}$ JOVINO PIZZI. O conteúdo moral do agir comunicativo. São Leopoldo: Unisinos, 2005, p. 148.

${ }^{248}$ Esses lugares-comuns, cujos extremos descambam ou para a absoluta inércia do julgador, ou para o excessivo ativismo judicial, são tratados (com ocultação das respectivas desvantagens de cada ponto de vista) na mesma obra por JoRge W. PEYRANO. Sobre el activismo judicial, in Activismo y garantismo procesal. Córdoba: Academia Nacional de Derecho y Ciencias Sociales de Córdoba, 2009, pp. 11-20, e por ADOLFO AlVARAdo Velloso. El garantismo... op. cit., pp. 145-163.

${ }^{249}$ Sobre a concepção do contraditório no processo liberal, no processo social e no processo democrático, em detalhado apanhado histórico, vide Humberto Theodoro Junior; Dierle José Coelho Nunes. Princípio do contraditório: tendências de mudança na sua aplicação, in Revista da Faculdade de Direito do Sul de Minas, v. 28, 2009, pp. 179-182.

${ }^{250}$ Humberto TheOdoro Junior; Dierle José COElHo Nunes. Princípio... op. cit., p. 178. 
e concretamente - participem da sua construção. Sob essa ótica, o contraditório processual surge como garantia de influência das partes nas decisões proferidas no processo ${ }^{251}$.

De fato, para participar da construção da norma concreta, não basta que as partes contem com um mecanismo que garanta o equilíbrio na obtenção de informações relevantes e a oportunidade de as partes reagirem a uma decisão desfavorável, consubstanciado no entendimento do princípio do contraditório segundo o binômio informação-reação clássico $^{252}$. Antes de tudo, as partes devem contar com um julgador que possa ser influenciado pelos argumentos apresentados, não apenas com a faculdade de reação, mas também de ação sobre o entendimento do julgador. Influência, nesse sentido, é “um meio de obter um efeito sobre a atitude ou opinião dos outros por meio de uma ação intencional (...) através do apelo ao senso subjetivo de obrigação [desses outros] (...) e sem a ameaça de sanção situacional" ${ }^{253}$, ou, de modo mais orientado para o processo, "um condicionamento significativo da conduta dos demais sujeitos do processo, realizado a partir de posições críticas ou omissões conclusivas, transmitidas comunicativamente e que, caso não existissem, poderiam, mantidas as demais condições, motivar o sujeito condicionado a agir de modo diverso" ${ }^{254}$.

${ }^{251}$ CÂNDIDO RANGel DinAmarCo. A instrumentalidade do processo. 3. ed. São Paulo: Malheiros, 1993, p. 27. No mesmo sentido: "In questo contesto, osserviamo che la comprensione del contraddittorio come diritto di influenza esprime la democrazia deliberativa nel processo: la società può influenzare gli atti decisori statali con la discussione argomentativa, ed il contraddittorio è il principio processuale che mette in pratica questo procedimento dialogico, aprendo il palco giurisdizionale al dibattito partecipativo e pluralista". ANTONIO DO PASSO CABRAL. Il principio del contraddittorio come diritto d'influenza e dovere di dibattito, in Rivista di diritto processuale, v. 2, 2005, p. 456.

${ }^{252}$ É de se notar que a Teoria Geral do Processo já superou essa noção simplificada do contraditório, conforme se depreende da leitura de duas edições distintas da obra fundamental sobre o assunto. Na mais antiga lê-se que "o contraditório é constituído por dois elementos: a) a informação; b) a possibilidade de reação", ao passo que, na mais recente, consta que o juiz "ouvindo uma [das partes], não pode deixar de ouvir a outra; somente assim se dará a ambas a oportunidade de expor suas razões, de apresentar suas provas, de influir no convencimento do juiz." Compare-se ANTONIO CARLOS DE ARAúJO CINTRA; ADA Pellegrini Grinover; CÂndido Rangel Dinamarco. Teoria Geral do Processo, 1. ed. São Paulo: RT, 1974, p. 27, com Antonio Carlos de Araújo Cintra; AdA PEllegrini Grinover; CÂndido Rangel DinAmARCO. Teoria Geral do Processo, 22. ed. São Paulo: Malheiros, 2006, p. 64.

${ }^{253}$ No original: "Influence is a way of having an effect on the attitudes and opinions of others through intentional (...) action" "through appeal to a subjective sense of obligation" "without reference to any threat of situational sanctions". TALCOTT PARSONS. On the concept of influence, in The public opinion quarterly, v. 27, 1963, pp. 38 e 45.

${ }^{254}$ ANTONIO do PASSO CABRAL. Nulidades... op. cit., p. 114. 
É por meio da influência exercida pelos argumentos trazidos à cognição do julgador que as partes efetivamente participam do processo, legitimando, com essa participação efetiva, a decisão tomada ${ }^{255}$.

Nesses termos, a imparcialidade não se revela como a inexistência de preferência ou predisposição do julgador a uma das teses apresentadas no processo ou à pessoa mesma de uma das partes, tal como comumente colocado pela doutrina ${ }^{256}$, em conceito que entendemos negativo. A imparcialidade deve ser objeto de um conceito positivo, que ponha em relevo a sua função de, a despeito das preferências do julgador (inerentes a qualquer ser humano), possibilitar a influência das partes no seu convencimento, pela consideração dos argumentos apresentados no processo.

Sob o ponto de vista metodológico-jurídico, a imparcialidade consiste na condição subjetiva do julgador em ser influenciado e persuadido ${ }^{257}$ pelos argumentos de ambas as (ou melhor, de qualquer das) partes no litígio, a despeito de suas alienáveis ${ }^{258}$ preferências ou predisposições.

\subsubsection{Preferência, pré-compreensão e imparcialidade}

Com os estudos de Heidegger ${ }^{259}$, o método hermenêutico descartou definitivamente a possibilidade de o indivíduo ser capaz de apreender a realidade sem recorrer à sua própria vivência e às marcas (posições, visões e concepções) que essa vivência imprimiu. De modo direto, "[a] interpretação de algo como algo funda-se, essencialmente, numa posição

\footnotetext{
${ }^{255}$ Não é por outra razão a repulsa cada vez mais eloquente na doutrina contra as declarações de "nulidadesurpresa", de ofício, pelo juiz. Sobre a necessidade de permitir a influência das partes previamente a tais declarações, vide RENZO CAVANI. Contra as "nulidades-surpresa": o direito fundamental ao contraditório diante da nulidade processual, in Revista de processo, v. 218, 2013, pp. 65-78.

${ }^{256}$ Vide capítulo 1 do presente estudo.

${ }^{257} \mathrm{O}$ conceito de influência adotado pelo presente estudo é próximo do conceito de persuasão apresentado por ENRIQUe M. FAlCón. Comunicación y proceso, in Revista de processo, n. 157, pp. 124-125.

${ }^{258}$ Vide capítulo 2.1.2 do presente estudo.

${ }^{259}$ MARTin HeIDEgGer. Ser e tempo (trad. Marcia Sá Cavalcante Schuback). Parte I, 15. ed. Petrópolis: Vozes, 2005.
} 
prévia, visão prévia e concepção prévia. A interpretação nunca é a apreensão de um dado preliminar isenta de pressuposições ${ }^{\text {260 }}$.

O indivíduo, ao interpretar algo, faz impregnar a interpretação da sua pré-compreensão daquilo que é interpretado ${ }^{261}$, ou seja, lança sobre a interpretação, necessariamente, a própria personalidade. Com isso, o ser do intérprete - resultado da sua vivência em um contexto social, linguístico, cultural etc. em certo tempo - interfere no produto da intepretação.

Ressaltando o caráter histórico da interpretação, Gadamer ${ }^{262}$ apontou que o indivíduo não se relaciona com a realidade, mas com as evidências dessa realidade traduzidas pela linguagem, construídas no curso da sua própria historicidade: ele, indivíduo, apropria-se dos acervos de ideias descritos linguisticamente para assim identificar e compreender a evidência do mundo que lhe é apresentada ${ }^{263}$. Por sua vez, esses acervos são objeto de uma tradição, pois são traduzidos pela consolidação das várias experiências humanas prévias. Ao interpretar um texto, por exemplo ${ }^{264}$, o intérprete parte necessariamente da sua précompreensão dos significados linguísticos, mas não pode ignorar que o autor (assim como o intérprete, imerso em uma tradição), ao construir o texto, terá nele impresso as suas próprias pré-compreensões e pré-conceitos. Isso impõe que "face a qualquer texto, nossa tarefa é não introduzir, direta e acriticamente, nossos próprios hábitos lingüísticos" 265.

\footnotetext{
${ }^{260}$ MARTIN HeIDEGGER. Ser... op. cit., p. 207. De modo também claro, "só interpretamos o que compreendemos previamente, conforme nossa faticidade, isto é, como ser no mundo, já circunscritos por objetos, vivendo em determinado estado de conexão com os outros". MARIA HeLENA DAMASCENO E SILVA MEGALE. Hermenêutica jurídica: interpretação das leis e dos contratos. Belo Horizonte: Faculdade de Direito da UFMG, 2001, p. 35.

${ }^{261}$ MARTin HeIDEGGER. Ser... op. cit., p. 207.

${ }^{262}$ Hans-Georg Gadamer. Verdade e método (trad. Flávio Paulo Meurer). 3. ed. Petrópolis: Vozes, 1999, passim.

${ }^{263}$ EDUARDO C. B. BITTAR. Hans-Georg Gadamer: a experiência hermenêutica e a experiência jurídica, in Hermenêutica plural. São Paulo: Martins Fontes, 2002, pp. 186.

${ }^{264}$ Para Gadamer, o processo hermenêutico é unitário, inexistindo distinção entre compreensão, interpretação e aplicação do trabalho do intérprete. Literalmente: "Nesse sentido nos vemos obrigados a dar um passo mais além da hermenêutica romântica, considerando como um processo unitário não somente a compreensão e interpretação, mas também a aplicação [...] a aplicação é um momento do processo hermenêutico, tão essencial e integrante como a compreensão e a interpretação". HANS-GEORG GADAMER. Verdade... op. cit., p. 460.

${ }^{265}$ HANS-GeORG GADAMER. Verdade... op. cit., p. 403.
} 
A interpretação se inicia com a revelação de um sentido prévio ao texto, originário das expectativas e da perspectiva do intérprete. No entanto, esse projeto prévio de significado é constantemente revisado no processo hermenêutico, conforme o intérprete penetra no sentido do texto, reprojetando constantemente a sua interpretação ${ }^{266}$ e operando a uma fusão de horizontes ${ }^{267}$.

Tranportando as noções acima para o processo, tem-se que - também sob uma ótica metodológico-hermenêutica - o julgador pode ter (rectius: tem) sua visão prévia sobre os sujeitos processuais, sobre os direitos que serão discutidos e sobre o litígio em si. Essa précompreensão pode ser mais ou menos tênue, a depender das experiências do julgador ${ }^{268}$. O que não se pode permitir é que seus pré-conceitos impeçam a apropriação e mensuração das opiniões e pontos de vista trazidos pelas partes no litígio, que as antecipações do julgador o imunizem contra a alteridade (entre as próprias convicções e os argumentos trazidos) inerente ao processo de interpretação. É por essa razão que o teste proposto pelas IBA Guidelines, que identificam como dúvidas justificadas sobre a imparcialidade a possibilidade de o árbitro ser influenciado por fatores outros além do mérito da causa ${ }^{269}$ apresentado pelas partes, parece-nos por demais impreciso, visto que inúmeras são as influências sofridas pelo julgador. Esse conceito pode servir para amparar o dever de revelação do árbitro, mas não para configurar a imparcialidade. É preciso que esses outros fatores, mais do que influenciarem o árbitro em algum sentido, impeçam o exercício da influência de uma das partes no processo.

Também sob a ótica metodológica-hermenêutica, portanto, a parcialidade do árbitro não se faz sentir pela existência de pré-compreensões, e sim pela eventual vedação que elas ofereçam à influência de ambas as partes no seu convencimento, no seu fechamento à argumentação das partes. Obviamente, se a argumentação for ruim, ela será ponderada e

\footnotetext{
${ }^{266}$ HANS-GEORG GADAMER. Verdade... op. cit., p. 402.

${ }^{267}$ HANS-GEORG GADAMER. Verdade... op. cit., p. 451.

268 "A filosofia hermenêtica alertou-nos para o perigo do objetivismo subjacente à abordagem metódica, objetivamente, da interpretação das expressões humanas. Ao desenvolvermos o nosso conhecimento da 'préestrutura' da compreensão, excluímos ainda a pressuposição simplista da possibilidade de um conhecimento totalmente objetivo ou neutro, dado o fato de termos já interpretado um objeto 'como' algo, antes mesmo de o chegarmos a investigar". JOSEF BLEICHER. Hermenêutica contemporânea (trad. Maria Georgina Segurado). Rio de Janeiro: Edições 70, 1980, p. 353. A lição é perfeitamente aplicável à hermenêutica jurídica realizada no curso de um processo arbitral.

${ }^{269}$ IBA Guidelines, Princípio Geral 2(c).
} 
afastada pelo árbitro, o que é muito diferente da situação de o árbitro estar imunizado à sua influência.

A questão que se coloca importante para o presente estudo - e que começa a ser respondida a partir do item seguinte - é o ponto a partir do qual a pré-compreensão do árbitro a respeito das questões a serem discutidas na arbitragem (ou a respeito das partes) é estabelecida de forma tal a imunizar o julgador contra a influência e persuasão dos argumentos que lhe são apresentados.

\subsection{Da subjetividade para a intersubjetividade: imparcialidade, probabilidade e aparência}

Se não há disputa quanto à imprescindibilidade da imparcialidade do árbitro - que o presente estudo defende consistir na condição subjetiva do julgador em ser influenciado pelos argumentos de ambas as partes no litígio -, não existe uma orientação concreta de como ela pode ser aferida. Sendo imperscrutável o íntimo do julgador ${ }^{270}$, a primeira forma de aferição consiste na declaração do próprio árbitro.

Se o árbitro declarar-se parcial, ele necessariamente será afastado do procedimento, não apenas porque assim exige o art. 16 da LA, mas também porque faltará condição necessária para a estruturação do modelo processual definido pelo art. $21, \S 2^{\circ}$ do mesmo texto legal, com o comprometimento da possibilidade do exercício da influência integrante do contraditório. Se o árbitro declarar-se imparcial, o panorama não será tão simples, por duas razões: ( $i$ ) o árbitro pode, de boa-fé, entender-se imparcial e não o ser, não admitindo para si mesmo que seria impermeável aos argumentos de uma das partes; ou (ii) o árbitro pode mentir.

\footnotetext{
${ }^{270}$ Literalmente: "As discussed above, partiality, or 'bias', is a subjective state of mind." Também: "Unless an arbitrator publicly announces his partiality or is overgeard in a moment of private admission, it is difficult to imagine how 'proof' would be obtained." Ambos os trechos de MARTIN F. GUSY; JAMES M. HOSKING; FranZ T. SCHWARZ. A guide to the ICDR International Arbitration Rules, New York: Oxford University Press, 2011, p. 111.
} 
A falta de confiabilidade na palavra do árbitro e a impossibilidade de aferição da sua psiquê não deixam alternativas além da análise das circunstâncias fáticas que poderão aparentar (e disso se trata: aparência, não no sentido que lhe atribui os "testes" ingleses ou norte-americanos, mais fraco que a "evidência" ou "real perigo", mas sim no sentido de “fenônemo apreensível intersubjetivamente") a sua parcialidade ou a sua imparcialidade frente a um padrão assumido como vinculante ou adequado. Assim, diante de determinadas circunstâncias fáticas, analisadas de acordo com certas premissas, é que se poderá analisar a aparência de que o árbitro seja ou não seja imparcial.

Ao tratar de aparência, o presente estudo não adentra o debate entre as correntes objetivista e subjetivista da Teoria do Conhecimento, evitando a questão de a aparência consistir na impressão errônea (pois baseada na percepção humana) sobre a real natureza do mundo ou de a aparência configurar a revelação de um fenômeno e assim constituir o único elemento sobre o qual o conhecimento se basearia ${ }^{271}$. Para o fim do presente estudo, basta apontar que na maioria dos casos - mas não necessariamente em todos - há relação entre o que é percebido (a aparência de parcialidade ou imparcialidade do árbitro) e o evento subjacente (a psiquê desse árbitro), derivada tanto da lógica quanto da experiência de um sujeito ou um grupo de sujeitos racionais que o analisa, experiência esta que inclui o conhecimento de casos em que esta aparência foi mensurada.

Ao se propor um método que se baseia na aparência, é necessário assumir o risco de se incorrer em erro quanto à constatação desse indicador, mesmo que no íntimo o julgador seja e permaneça imparcial. Pode ocorrer de se tachar de parcial um árbitro que se comportou de modo incabível ou por demais inadequado, mas que não permitiria que esse comportamento influenciasse sua decisão (permanecendo, em seu íntimo, imparcial); é também possível que se afirme ser imparcial o árbitro que tenha se comportado adequadamente, mas que possua tendenciosidade contra ou a favor de uma das partes em nível suficiente a impedir a influência dos argumentos que lhe serão apresentados no processo arbitral (permanecendo, em seu íntimo, parcial). Esses são os riscos não elimináveis do método baseado na aparência. No entanto, a impossibilidade de utilização de outro método impõe a assunção desses riscos.

${ }^{271}$ Nicola Abbagnano. Dicionário de filosofia (trad. Alfredo Borsi). São Paulo: Martins Fontes, 2007, pp. 79-81. 
Há quem defenda a aparência de imparcialidade do árbitro como um valor em si, sob a consideração de que a arbitragem é baseada na confiança e que, por isso, o método alternativo de solução de controvérsias somente se desenvolveria em um ambiente ético ${ }^{272}$. Uma visão um pouco diferente, que traça um paralelo entre a independência judicial e a imparcialidade do árbitro como um elemento-chave para a manutenção da credibilidade e legitimidade dos tribunais arbitrais, chega à mesma conclusão ${ }^{273}$. O presente estudo, porém, não analisa essa questão (que concerne à sociologia), privilegiando a abordagem da imparcialidade no âmbito do direito processual e utilizando-se da aparência como elemento de análise, não como valor em si.

${ }^{272}$ BRUNO MANZANARES BASTIDA. The independence... op. cit., p. 3.

${ }^{273}$ Ponto de vista consolidado na expressão: "justice should not only be done but should manifestly and undoubtedly be seen to be done". 


\section{CAPÍTULO 3. CONSTRUÇÃO DA NORMA CONCRETA E SUAS PREMISSAS}

\subsection{Conceito de imparcialidade e estrutura normativa}

Tal como visto, o presente estudo partiu da premissa de que sempre um julgador é influenciado pelas experiências às quais se expôs e por seus próprios pré-conceitos, afastando a noção genérica de imparcialidade como a não exposição do julgador a outras influências além dos argumentos oferecidos pelas partes no curso do processo.

Eliminada a noção genérica, o conceito de imparcialidade foi reconstruído em vista da sua função na relação jurídico-processual, que é permitir às partes o exercício da influência, por seus argumentos, na decisão final do julgador, de modo que sua ausência destrói a própria estrutura e subverte o papel da relação para a qual funciona. Com isso, é possível atribuir à parcialidade um conteúdo, qual seja, a vedação, o óbice, a imunização do árbitro à influência potencial dos argumentos das partes, conceito esse que não admite gradação: ou o julgador é imparcial ou não é.

Consistindo essa vedação um evento eminentemente psíquico e, portanto, subjetivo, sua demonstração e mensuração somente podem ser feitas com base na aparência inferida a partir de fatos do mundo concreto.

O conceito de imparcialidade e a sua revelação através da aparência não são suficientes para a solução de casos concretos, ao menos não são suficientes para estabelecer uma orientação interpretativa relativamente harmônica ou estável, que confira segurança e previsibilidade mínimas exigidas pelo direito no tratamento de casos semelhantes. É preciso, assim, entender a estrutura normativa que permite a utilização do conceito ou, por outras palavras, entender como o intérprete pode trabalhar esse conceito à luz da estrutura normativa à sua disposição, criando norma concreta que, aplicada ao caso, possa sustentar a conclusão de parcialidade ou imparcialidade do árbitro. Essas são o que o presente estudo denomina premissas de estrutura. 
O reconhecimento e o respeito às premissas de estrutura não esgotam o trabalho do intérprete. $\mathrm{O}$ direito trabalha a partir do mundo concreto (quando elege eventos que integram a hipótese de fato normativa) e para o mundo concreto (ao regular eventos que devem ocorrer a título de sanção) ${ }^{274}$, razão pela qual uma orientação interpretativa relativamente harmônica ou estável da imparcialidade não pode prescindir de uma análise atenta dos eventos do mundo concreto a partir dos quais se possa legitimamente inferir a aparência da imparcialidade. Além da estrutura que a norma concreta aplicável a determinado caso deve respeitar, ela também deve possuir um conteúdo fático-hipotético adequado, respeitando certas premissas de conteúdo derivadas da própria experiência jurídica.

Como essa experiência da arbitragem ocorre sobretudo em um mundo à parte ${ }^{275}$, habitado por profissionais que figuram ora como advogados, ora como árbitros, que se conhecem e se reconhecem, possuindo experiências profissionais - e muitas vezes histórias de vida em comum, é necessário que a análise das premissas de conteúdo seja precedida de um breve olhar sobre o ambiente institucional no qual a arbitragem se desenvolve.

Por fim, sendo a proposta do presente estudo considerar a imparcialidade a partir da aparência, que nada mais é senão um juízo feito sobre evidências fáticas coletadas (ou melhor, escolhidas pelo intérprete), o presente capítulo busca identificar - não sem

\footnotetext{
${ }^{274}$ A estrutura da norma jurídica é analisada por MARCOS BERNARDES DE MELO. Teoria do fato jurídico: plano da existência. 7. ed. São Paulo: Saraiva, 1995, pp. 35-37 (suporte fático) e pp. 51-53 (preceito ou sanção).

${ }^{275}$ Sobre o controle da participação no mercado da arbitragem, especialmente para a função de árbitro, vide CATHERINE A. ROGERS. The vocation of the international arbitrator, in American University international law review, v. 20, 2005, pp. 977-980. Da mesma autora, sobre o desenvolvimento de uma "arbitral rule of law" CATHARINE A. ROGERS. Regulating international arbitrators: a functional approach to developing standards of conduct, in Stanford journal of international law, v. 41, 2005, pp. 66-67. As preocupações da autora com as assimetrias de informação sobre os árbitros levaram-na a formular o "International Arbitrator Information Project", pelo qual ela propõe que "each arbitrator would have a dedicated webpage that would be electronically searchable. Each page would include standard biographic information, such as education, professional training, nationality, language skills, and arbitration experience. Arbitrator webpages would also include links to all publicly available arbitral awards associated with the arbitrator, and all judicial opinions (translated into English or summarized in English) that reference the arbitrators or their awards. It would also include links to arbitrators' academic and professional publications, again fully-or partiallytranslated into English where necessary. Additionally, the Project would also allow searchable access to publications by other arbitrators and academics that comment on the relevant arbitrator's publications, awards, and judicial decisions that rule on or reference those publications or awards". Sobre o tema, vide CATHERINE A. ROGERS. The International Arbitrator Information Project: from an ideation to operation, in Kluwer arbitration blog; disponível no endereço eletrônico http://kluwerarbitrationblog.com/blog/2012/12/10/the-international-arbitrator-information-project-from-anideation-to-operation/; consulta em 21.02.2014.
} 
reconhecer as dificuldades e aproximações envolvidas - quem seria o autor ideal desse juízo: partes, árbitros ou terceiros.

\subsection{Premissas de estrutura}

O primeiro trabalho que o intérprete terá para a construção da norma concreta a respeito da parcialidade ou imparcialidade do árbitro será identificar a forma de padronização do conceito pelas regras aplicáveis a determinado procedimento.

\subsubsection{Primeira premissa de estrutura: modelo democrático de processo como forma de orientação na interpretação das hipóteses expressamente previstas e de integração de hipóteses não previstas expressamente}

Conforme o presente estudo demonstrou, as opções legislativas de padronização da imparcialidade dos árbitros ensejam problemas práticos de ordens diversas: ( $i$ ) a técnica de padronização mediante exclusiva tipificação legal dos casos de recusa ou impugnação deixa de tratar grande variedade de hipóteses passíveis de ocorrerem nos casos concretos; (ii) a técnica de padronização mediante a equiparação às causas de impedimento ou suspeição de juízes impõe ao intérprete o esforço argumentativo de adequar aquilo que foi legislado ao servidor do Estado (escolhido para julgar uma causa segundo regras de distribuição de competência) a um particular (escolhido direta ou indiretamente pelas próprias partes); e (iii) a técnica de padronização mediante o estabelecimento de um estado de coisas impõe ao intérprete o desafio de preenchimento do suporte fático da regra a ser aplicada, resultando em maior dificuldade para o exercício e controle da interpretação, diminuindo a previsibilidade das condutas objetivadas.

Não importa qual seja a opção legislativa, o intérprete somente superará os problemas hermenêuticos ao recorrer ao modelo democrático de processo e à consequente conceituação da imparcialidade como não fechamento do árbitro à influência dos argumentos das partes, que será aferida mediante as aparências que os eventos 
objetivamente verificáveis ensejarão no caso concreto. Como se viu, nem mesmo os ordenamentos que, já antecipando a problemática derivada da impossibilidade de aferição da condição subjetiva (psiquê) do árbitro, positivaram expressamente a existência de dúvidas justificadas como fator denotativo da parcialidade ${ }^{276}$, favorecem a superação dos problemas hermenêuticos se não for levado em conta que a imparcialidade consiste no óbice à influência dos argumentos das partes no julgador. Daí a necessidade do recurso ao modelo democrático de processo como forma de orientar e harmonizar eventuais hipóteses previstas em lei, e, eventualmente, como forma de integrar situações não previstas expressamente, mas que igualmente imunizam o árbitro ao exercício da influência.

As hipóteses de imparcialidade eventualmente tipificadas em lei ou outras regras vinculantes carecem - tal como qualquer outro texto - ser interpretadas mediante a atividade da subsunção, que consiste na adaptação das propriedades da hipótese do fato prevista linguisticamente no texto normativo às propriedades da descrição linguística do evento ocorrido no mundo social. Assim, o intérprete adapta o juízo que faz da hipótese prevista ao juízo que extrai do evento social ${ }^{277}$.

Se o ordenamento que rege o processo arbitral acata o modelo democrático de processo que, entre outras características, prevê a imparcialidade do árbitro como um estado de coisas necessário, essa previsão exerce eficácia integrativa ${ }^{278}$, permitindo ao intérprete a eleição do comportamento necessário para se atingir o conteúdo operativo da imparcialidade (não imunização do árbitro aos argumentos das partes), efetivamente criando a hipótese de fato da norma que regulará o caso concreto.

Cabe ao intérprete ${ }^{279}$ escolher, dentre todos os eventos ocorridos no mundo fático, aqueles sobre os quais a lei lhe permite projetar critérios que lhe são interessantes ressaltar ${ }^{280}$.

\footnotetext{
${ }^{276}$ É o caso das legislações que seguem a Lei Modelo UNCITRAL. Vide capítulos 1.3.2.3 e 1.3.3.2 do presente estudo.

${ }^{277}$ Trata-se de “(...) uma adaptação entre as propriedades do ato comunicativo jurídico geral e abstrato e o evento social ocorrido, com a criação de um micro-sistema de formulações jurídicas destinado à construção da verdade a ser incorporada pelo sistema, dando origem ao ato comunicativo jurídico individual e concreto (...)”. ERnANi ConTIPELLI. Aplicação da norma jurídica. São Paulo: Quartier Latin, 2007, p. 80.

${ }^{278}$ HuMBerto Ávild. Teoria... op. cit., pp. 104-105.

279 "A adequação do evento social às categorias dos atos comunicativos previstos na norma jurídica geral e abstrata depende da atuação do intérpretelaplicador". ERNANI CONTIPELLI. Aplicação... op. cit., p. 120.
} 
Nesse sentido, o direito não se prende aos fatos em si, mas ao uso que lhes é dado como referência para o estabelecimento da norma que regulará determinada relação jurídica, em uma estratégia retrospectiva ${ }^{281}$ ou de conformação da situação do fato (como enunciado) ao texto normativo, em um "ir e vir da perspectiva",282 desenvolvido pelo intérprete.

O direito brasileiro, como já afirmado no presente estudo, trabalha diretamente ${ }^{283}$ a imparcialidade do árbitro em três passagens da LA: ( $i$ ) estabelecendo-a como modo de ser do processo no art. $21, \S 2^{\circ}$; (ii) impondo-a ao árbitro no art. $13, \S 6^{\circ}$, embora sem a definir; e (iii) impedindo, no art. 14, caput, "de funcionar como árbitro" o profissional que ostentar, frente às partes ou ao litígio "algumas das relações que caracterizam os casos de impedimento ou suspeição de juizes" previstas no arts. 134 e 135 do CPC. Ao assim proceder, a lei acatou duas técnicas: a técnica da equiparação (positivada de modo vago pela referência a "algumas das relações", sem especificar quais relações seriam, e deixando esse ônus para o intérprete diante do caso concreto) e a técnica do estabelecimento de um estado de coisas voltado à imparcialidade.

Assim, a despeito de a lei impedir que sejam árbitros pessoas que ostentem "algumas das relações" que configurem impedimento e suspeição de juizes, esse não deve ser - e não é o único critério de padronização da imparcialidade dos árbitros no ordenamento brasileiro $^{284}$. Ao contrário, ao assimilar o modelo democrático de processo, consoante art. 21, a LA demanda que outros casos não expressamente previstos ou referidos também sejam considerados, na medida em que eles possam ser enquadrados na situação de não permitir que o árbitro seja persuadido e influenciado pelos argumentos de ambas as partes na arbitragem. Tome-se o exemplo da relação de amizade íntima entre árbitro e advogado,

\footnotetext{
${ }^{280}$ Nesse sentido: "Law provides nothing but a network of criteria exteriorly and posteriorly projected onto the event. The underlying idea is to afford that I can break an event into sets of concepts and conceptual connections (artificially established as seen from any purely theoretical reconstruction of its factors and elements) so that, by their standards, I can issue a judgment upon the fact". CSABA VARGA. The noncognitive character of the judicial establishment of facts, in Legal System and practical reason. Stuttgart: Franz Steiner, 1994, p. 235.

${ }^{281}$ CSABA VARGA. The non-cognitive... op. cit., p. 238.

${ }^{282}$ KARL LARENZ. Metodologia da ciência do direito (trad. José Lamego). 3. ed. Lisboa: Fundação Calouste Gulbenkian, 1997, p. 395.

${ }^{283} \mathrm{O}$ art. $14, \S 1^{\circ}$, objetivando o dever de revelação do árbitro, trabalha com a imparcialidade indiretamente.

${ }^{284}$ Contra, conforme já citado, LuIz OlAvo BAPTISTA. Inutilidades... op. cit., p. 28.
} 
cujo correlato para o juiz não está previsto nos arts. 134 e 135 do $\mathrm{CPC}^{285}$. Não há dúvida e assim se reconheceu em diversas decisões judiciais segundo legislações que também estabelecem um estado de coisas - de que, a despeito da ausência de previsão expressa, o caso em questão demanda o reconhecimento da parcialidade do árbitro ${ }^{286}$.

Assim, a análise da imparcialidade do árbitro no direito brasileiro demanda não apenas o exame das causas de suspeição e impedimento dos juízes (e sua adaptação para o processo arbitral) ou de eventuais outras regras vinculantes escolhidas pelas partes (tais como os regulamentos e os códigos de ética das instituições arbitrais), como também o cotejo do modo de ser imposto pela lei com as circunstâncias específicas de determinado caso concreto (o que permite a criação de norma não ligada às situações já previstas na hipótese legal ou consensualmente vinculantes). Assim, seja com regras mais específicas, seja com apoio na regra geral de vedação à parcialidade do árbitro, o intérprete deve elaborar uma proposta de norma que permita averiguar a aparência de imparcialidade do árbitro no caso concreto.

Se há regras vinculantes específicas (vinculantes por força de lei ou de consenso), o trabalho do intérprete é facilitado, consistindo no estabelecimento da relação entre a hipótese prevista na regra vinculante específica e o caso concreto. Exemplo disso é o árbitro amigo íntimo de uma das partes (art. 13, § $6^{\circ}$, da LA, c/c art 135, inc. I, do CPC), na qual o intérprete deverá demonstrar em que consiste uma amizade íntima normativamente prevista e demonstrar que os elementos distintivos dessa relação ocorrem no caso prático.

Registre-se o posicionamento desenhado pelo julgamento do caso Merit v. Leatherby, segundo o qual as regras consensuais a respeito da imparcialidade fixadas no regulamento da American Arbitration Association (AAA), impondo um padrão mais rígido para a avaliação da imparcialidade do que o constante na Section 10 do FAA, não seriam um ponto de partida adequado para a perquirição da validade de uma sentença impugnada em

\footnotetext{
${ }^{285}$ Tal evento, segundo a melhor doutrina, não configura impedimento ou suspeição do juiz. Sobre o tema, José Rogério CRUZ e TUCCI. Do relacionamento juiz-advogado como motivo de suspeição, in Revista dos Tribunais, v. 756, 1998, p. 69-76.

${ }^{286}$ Vide capítulo 3.4.4 do presente estudo.
} 
razão da parcialidade do árbitro, visto que o regulamento não teria força de $1 \mathrm{ei}^{287}$. Não é possível concordar com essa tese à luz do direito brasileiro que, tal como já apontado, estabelece um estado de coisas que pode ser padronizado pelas partes, conquanto não contrarie o modelo democrático de processo.

Mas como criar uma proposta de norma sem que haja qualquer regra vinculante que trate da hipótese verificada no caso concreto?

Quando essas referências não existem - e assim é o caso do direito brasileiro ao estabelecer (ao lado de padrões análogos aos dos juízes para a imparcialidade dos árbitros) um estado de coisas que, como defendido no presente estudo, impõe ao árbitro que esteja aberto à influência exercida pelos argumentos das partes -, a liberdade do intérprete na eleição dos eventos que se encaixariam ${ }^{288}$ na norma criada para o caso concreto é maior. No entanto, igualmente maior é o ônus argumentativo do intérprete ${ }^{289}$ para justificar que tal evento do mundo social se enquadra entre aqueles que atentam contra a imparcialidade.

Se não há regras vinculantes que tratem do evento ocorrido no caso concreto, o intérprete verificará se existem regras não vinculantes, categoria em que se encontram tanto eventual corpo de diretrizes não adotadas expressamente no procedimento arbitral (como, por exemplo, as IBA Guidelines), como leis e regulamentos não aplicáveis ao caso concreto, mas que guardam alguma similitude com a situação que se quer analisar. A partir dessas regras, o intérprete apresentará uma proposta normativa que seja suportada pelo estado de coisas imposto pela lei brasileira a respeito da imparcialidade do árbitro (arts. $21, \S 2^{\circ}$ e 13 , $\S 6^{\circ}$, da LA).

Tão importante quanto um corpo de regras é a interpretação que lhe é dada ${ }^{290}$. E por essa razão, não se pode descartar o valor da jurisprudência e da doutrina - seja no trato das

\footnotetext{
${ }^{287}$ Caso Merit Insurance Co. v. Leatherby Insurance Co., 714 F.2d 673 (7th Cir. 1983), decisão disponível no endereço eletrônico https://www.casetext.com/case/merit-ins-co-v-leatherby-ins-co-2/; consulta em 21.02.2014.

${ }^{288}$ CSABA VARGA. The non-cognitive... op. cit., p. 234.

${ }^{289}$ HuMBerto Ávila. Teoria... op. cit., pp. 107-108.

${ }^{290}$ A moderna hermenêutica jurídica reconhece que norma não se confunde com o seu substrato verbal (a regra), mas sim consiste no juízo que o intérprete retira desse substrato. Sobre o tema, e exemplo das "idas $e$ vindas" do intérprete na compreensão de uma regra, vide KARL ENGISCH. Introdução ao pensamento jurídico (trad. J. Baptista Machado). 7. ed. Lisboa: Fundação Calouste Gulbenkian, 1996, pp. 124-127.
} 
regras vinculantes, seja das não vinculantes - para a construção da proposta normativa na qual a aparência de imparcialidade no caso concreto será tratada.

Não se pode olvidar que, além da indeterminação dos comportamentos necessários voltados para a obtenção do estado de coisas relativo à imparcialidade, parte das regras mais específicas nas quais a proposta normativa do intérprete poderá se basear envolve conceitos indeterminados ${ }^{291}$ - que carecem de um preenchimento valorativo -, ou, sob diferente prisma, envolve cláusulas gerais ${ }^{292}$ - que são completadas mediante referência a regras extrajurídicas, de modo que sua valoração impõe a utilização de modelos de comportamento e pautas de valoração -, tal como se vê na expressão "amigo íntimo". Assim, a formulação de uma proposta de norma para o caso concreto demandará do intérprete uma atuação não apenas dedutiva, mas também de classificação e valoração, segundo aquilo que comumente se espera (em certo momento histórico e em certa cultura) do comportamento adequado de um agente imparcial. Eis aí a abertura da proposta normativa para os dados da realidade e às regras da experiência que o intérprete, segundo a sua visão de mundo, dele extrai ${ }^{293}$.

Essa valoração do evento social que integrará a proposta normativa deve se dar no estreito ângulo entre dois vértices, com vistas à proteção da utilidade e segurança do mecanismo de solução de controvérsia: a interpretação daquilo que comumente se espera a respeito de um evento que envolve a imparcialidade não pode ser muito rigorosa ou restritiva - o que redundaria na impossibilidade de demonstração da imparcialidade, com a consequente maior dificuldade de exclusão dos árbitros aparentemente parciais; e, no outro vértice, a interpretação daquilo que comumente se espera a respeito de um evento que envolve a imparcialidade do árbitro não pode ser muito indulgente ou ampliativa - o que redundaria na desmesurada facilidade de demonstração da parcialidade, criando um estímulo para a utilização dessa alegação em técnicas dilatórias pela parte que quer frustrar a utilização ou o resultado do método arbitral. De fato, quanto mais amplas forem as hipóteses que possam caracterizar a imparcialidade do árbitro e quanto menos demonstrações elas demandarem para que se configure a aparência de parcialidade, mais fácil será às partes eliminarem o

\footnotetext{
${ }^{291}$ KARL ENGISCH. Introdução... op. cit., pp. 210-214.

${ }^{292}$ Ruy Alves HenriQue FILho. Direitos fundamentais e processo. São Paulo: Renovar, 2008, p. 231. Vide também, por referência ao autor citado, JUDITH MARTINS-COSTA. $O$ direito privado... op. cit., esp. pp. 6-8.

${ }^{293}$ KRZYSZTOF BURDZY. The search for certainty. Singapore: Word Scientific Publishing, 2009, p. 179.
} 
árbitro tido como parcial. De outra banda, ao se ampliar as hipóteses e demandar pouca demonstração, abre-se espaço para manobras do litigante que tenha interesse em tumultuar ou retardar o processo arbitral ou mesmo em anular a sentença arbitral no Poder Judiciário.

\subsubsection{Segunda premissa de estrutura: satisfação de postulados hermenêuticos ou das justificativas de "segunda ordem"}

Enquanto a criação da norma concreta com base em hipóteses já previstas nas regras vinculantes exige a subsunção do juízo do intérprete a respeito do evento social ao juízo desse mesmo intérprete a respeito da previsão de fato existente na regra vinculante específica, a criação de norma a partir de regra que impõe um estado de coisas deve ser realizada segundo argumentação que satisfaça determinadas premissas de sentido ou que siga certos postulados hermenêuticos. Se assim não fosse, qualquer intérprete poderia construir a norma que melhor lhe aprouvesse, sem que ela encontrasse respaldo sistemático-jurídico, ou seja, sem a possibilidade de qualquer controle sobre a sua produção $^{294}$.

A seguir, serão tratados (dentro dos limites que servem ao objeto central do presente estudo) os postulados hermenêuticos e as premissas de sentido importantes para a orientação e controle da proposta normativa formulada pelo intérprete com base no estado de coisas colocado pela LA relativamente à imparcialidade do árbitro.

O primeiro dos postulados hermenêuticos é a razoabilidade como equidade, que significa a aplicação da norma levando-se em consideração o que comumente acontece ${ }^{295}$, segundo a presunção de que os fatos ocorreram dentro da normalidade (nesse sentido, considerando que o árbitro esteja de boa-fé). Também como postulado hermenêutico, a razoabilidade impõe que, para a demonstração da parcialidade, seja também demonstrado que os eventos que o intérprete utiliza para elaborar a norma para o caso concreto estão fora do que

\footnotetext{
${ }^{294}$ Não por outra razão " $[u] m$ ordenamento, como sistema, contém um repertório, contém também uma estrutura". TÉRCIO SAMPAIO FERRAZ JÚNIOR. Introdução ao estudo do direito. 2. ed. São Paulo: RT, 1996, p. 175. Colocando o processo arbitral como subsistema, destacando seu fechamento operacional e abertura cognitiva, vide EdUARdo de AlbuQUerque PARENTE. Processo... op. cit., pp. 40-60.

${ }^{295}$ HUMBERTO ÁvilA. Teoria... op. cit., p. 173.
} 
normalmente ocorre e do que normalmente se espera do comportamento do árbitro. É a razoabilidade como equidade que impõe a comparação do que comumente acontece com as particularidades do evento que ensejariam, segundo o intérprete, a aparência de parcialidade do árbitro. Em assim fazendo, impõe, por consequência, que o intérprete demonstre $(i)$ por meio da jurisprudência brasileira ou estrangeira, regras não vinculantes emanadas de lei estrangeira ou em guias de melhores práticas, doutrina etc., quais são as práticas, os comportamentos e as situações aceitas e (ii) por que a prática, comportamento e situação do caso específico se distancia daqueles aceitos. Para tanto, quanto mais detalhadamente forem descritas as circunstâncias envolvidas no caso específico - ou seja, quanto mais detalhes a respeito da cadência de eventos, do tempo em que eles ocorreram, dos personagens envolvidos, entre outros - menos difícil será aproximar ou afastar esse caso específico do que comumente acontece.

Embora haja autores que defendam que a razoabilidade seja um conceito jurídico norteamericano equivalente ou aproximado do conceito de proporcionalidade dos alemães ${ }^{296}$, a melhor doutrina estabelece diferenças entre ambos ${ }^{297}$. A razoabilidade é diferente da proporcionalidade porque a primeira exige a consideração das particularidades individuais do caso, enquanto a segunda exige uma análise da relação (proporcional) entre meios e fins.

A aplicação da proporcionalidade - o segundo postulado hermenêutico para a orientação e controle da proposta normativa quando não há conduta descrita nas regras vinculantes envolve o exame de três elementos, quais sejam, adequação, necessidade e proporcionalidade em sentido estrito. Há divergência sobre a necessidade de que todos os três sejam examinados cumulativamente ${ }^{298}$ ou que o sejam de modo subsidiário, isto é, de que o elemento seguinte seja examinado apenas se o anterior não permitir a solução do problema $^{299}$.

\footnotetext{
${ }^{296}$ Entre eles, JUAN FRANCISCO LINARES. Razonabilidad de las leyes. 2. ed. Buenos Aires: Astreas, 1970, p. 29. SUZANA DE TOLEDO BARROS. O princípio da proporcionalidade e o controle de constitucionalidade das leis restritivas de direitos fundamentais. 2. ed. Brasília: Brasília Jurídica, 2000, p. 57. Sobre desnecessidade de distinção entre a razoabilidade e a proporcionalidade no processo civil, vide MARCELO JOSÉ MAGALHÃES Bonicio. Proporcionalidade e processo. São Paulo: Atlas, 2006, pp. 28-34.

${ }^{297}$ Sobre o assunto, com ampla base bibliográfica e análise histórica, vide VIRGÍLIO AFONSO DA SILVA. $O$ proporcional e o razoável, in Revista dos Tribunais on line, v. 798, 2002, pp. 23-50.

${ }^{298}$ HUMBERTo Ávila. Teoria... op. cit.p. 183.

${ }^{299}$ VIRGÍLIO AFONSO DA SILVA. O proporcional... op. cit., pp. 34-35.
} 
A adequação exige que o meio escolhido fomente a promoção do fim estabelecido, relação que pode ser analisada em três aspectos: quantitativo, qualitativo e probabilístico. Sob o aspecto quantitativo, um meio pode promover mais, menos ou igualmente um fim que outro; sob o aspecto qualitativo, um meio pode promover pior, igualmente ou melhor um fim do que outro meio; e sob o aspecto probabilístico, um meio pode promover com mais, menos ou igual certeza um fim que outros meios. Conjugando esses critérios, um meio pode promover mais intensamente, melhor e mais seguramente um fim que outros. É o que deve ser buscado pelo intérprete ${ }^{300}$ ao propor que determinado comportamento do árbitro ou fato que o envolva recomende a necessidade da sua impugnação ou a anulação da sentença que ele tenha proferido em nome da proteção da imparcialidade de modo mais intenso, melhor e mais seguramente que a manutenção do árbitro ou da validade da sentença proferida. A anulação da sentença por conta de um parecer sobre a causa, dado pelo árbitro ao advogado de uma das partes, anos antes da instauração do processo arbitral, é adequada para o fomento da aparência de imparcialidade? E se o parecer tiver sido sobre causa similar? E se tiver sido dado sobre causa totalmente diferente? E se, além de ser sobre causa totalmente diferente, tiver sido dado ao escritório ao qual pertence o advogado que patrocina a arbitragem, anos antes de ele se integrar à banca? E se, ao invés de um parecer, tiverem sido dez? É no critério da adequação que o intérprete verificará se a medida proposta para a manutenção da imparcialidade efetivamente é capaz de fomentá$1 a^{301}$.

A avaliação da necessidade enseja o exame de outros meios que possam promover com a mesma intensidade o fim perseguido, com a menor restrição possível ao direito fundamental atingido. A necessidade é examinada em caráter imprescindivelmente comparativo entre os vários meios possíveis, daí se distinguindo do exame da adequação, que é feito em caráter absoluto ${ }^{302}$. O intérprete deverá examinar o fim eleito e os direitos fundamentais que serão limitados pelos meios possíveis voltados ao fim desejado. Nesse sentido, o afastamento do árbitro ou a anulação da sentença por ele proferida por conta de

\footnotetext{
${ }^{300}$ Humberto Ávila. Teoria... op. cit., p. 188.

${ }^{301}$ VIRGÍlIO AFONSO DA SILVA. O proporcional... op. cit., pp. 36-37.

302 Virgílio AfOnSo DA SILVA. O proporcional... op. cit., p. 38. Com entendimento diverso, no sentido de que a necessidade envolve o exame da igualdade de adequação entre vários meios para a promoção do fim e, posteriormente, o exame do meio menos restritivo, HUMBERTO ÁvilA. Teoria... op. cit., p. 193.
} 
uma aparência de imparcialidade está a patrocinar o devido processo ou o comprometendo por privilegiar uma tática que pode ser dilatória? A parte que impugna o árbitro ou requer a anulação da sentença já conhecia ou poderia ter conhecido o fato que apontou ser nocivo à imparcialidade, de modo que o não afastamento do árbitro ou a não anulação da sentença irá promover o devido processo sem o comprometimento e como respeito do direito fundamental à segurança jurídica? Essas são, entre outras, as perguntas que devem ser respondidas nesse item de análise.

A análise da proporcionalidade em sentido estrito exige a consideração ou sopesamento entre a intensidade da restrição a um direito fundamental e a importância da realização do fim, de modo que os motivos que fundamentam a adoção da medida necessária para atingir o estado de coisas eleito tenham peso suficiente para justificar a restrição ao direito fundamental $^{303}$. Seria proporcional restringir o direito de livre associação do árbitro para que se preserve a aparência de imparcialidade no caso concreto, impedindo-o de participar de associações que tenham por objetivo o estudo da matéria ao qual o árbitro se dedica? Seria proporcional restringir o direito ao trabalho do árbitro como professor ou parecerista para que a aparência de imparcialidade seja mantida? Se sim, qual a correta medida dessa restrição? Haveria um limite temporal?

Logo se vê que a análise da adequação, necessidade e proporcionalidade em sentido estrito constitui ferramenta poderosa para a criação de normas concretas, sobretudo as baseadas no estado de coisas imposto pela LA.

Outro método de apoio e controle para a criação de normas para caso concreto, elaborado na experiência do commom law (e, portanto, mais voltado à explicação a posteriori do fenômeno da decisão judicial do que propriamente fornecer uma linha mestra a priori para o trabalho do intérprete ${ }^{304}$ ), baseia-se na ideia de justificações de segunda ordem, pelas

\footnotetext{
${ }^{303}$ VIRGÍlIO AFONSO DA SILVA. O proporcional... op. cit., p. 195.

${ }^{304}$ GuIdo Fernando Silva SoAReS. Common law... op. cit., p. 53. Direta e sucinta descrição do contraste entre o caráter mais dedutivo característico da interpretação segundo a tradição do civil law frente ao caráter mais indutivo característico da tradição do common law, já foi colocada sob os contextos: (i) gramatical (ligação do civil law à construção de conceitos abstratos e à sua interrelação); (ii) de visão panorâmica (apego do civil law à agregação dos conteúdos jurídicos em grandes campos, tais como o do direito público e privado, processual e substantivo, entre outros, cada qual com características próprias e a partir dos quais os temas mais específicos são analisados); e (iii) de modelo interpretativo (busca do civil law na consistência lógica do pensamento - em respeito aos dois contextos anteriormente mencionados - na solução de problemas práticos, e não no pensamento a partir do problema). MIRJAN R. DAMASKA. A continental lawyer
} 
quais tais normas devem fazer sentido no mundo e sentido no contexto do sistema jurídico $^{305}$. Para que a norma proposta pelo intérprete faça sentido no mundo, este deve (i) levar em conta as consequências da sua adoção e da sua não adoção (examinando-se os tipos de decisão que seriam tomados em outros casos que se enquadrariam nos termos da norma proposta) e (ii) avaliar a aceitabilidade ou inaceitabilidade dessas consequências, consoante o grau de justiça ou injustiça diante das escolhas de valor predominantes (avaliação que, até certo ponto, é subjetiva) ${ }^{306}$. Por sua vez, para que a norma proposta faça sentido no contexto do sistema jurídico, ela deve respeitar a coesão e coerência desse sistema $^{307}$, sendo que a primeira é respeitada se a norma não contradisser qualquer outra extraída no sistema, e a segunda é respeitada se a norma, analisada frente às demais já extraídas, contribuir para proteger e não contrariar os valores aos quais essas normas se voltam a proteger.

De modo mais preciso, a análise da coesão enseja a demonstração de que a norma proposta é compatível com as demais já existentes e extrapolação racional a partir delas, devendo o intérprete, se necessário, recorrer à analogia ou à análise jurisprudencial ${ }^{308}$. A coerência se revela quando a norma proposta faz sentido se considerada em conjunto com as demais, perseguindo o fim determinado pelos valores que lhe são comuns ${ }^{309}$, tendo também aqui a argumentação por analogia e a análise jurisprudencial papel importante.

Seja qual for o método utilizado - total ou parcialmente pelo intérprete - é certo que a construção da norma a regular o caso concreto envolve a consideração do fim buscado e das consequências positivas e negativas, bem como jurídicas e extrajurídicas, da sua adoção ou da sua não adoção. Daí falar-se em utilidade, necessidade, adequação, aceitabilidade e coerência, entre outros conceitos. As considerações a respeito dos critérios de construção normativa e das respectivas consequências, no sentido de identificar a imparcialidade quando presentes certas circunstâncias fáticas e não identificá-la quando

in an american law school: trials and tribunals of adjustment, in University of Pennsylvania law review, 1968, pp. 1365-1370.

${ }^{305}$ NeIL MACCORMICK. Argumentação jurídica e teoria do direito (trad. Waldéa Barcelos). São Paulo: Martins Fontes, 2006, p. 131.

${ }^{306}$ NeIl MACCORMICK. Argumentação... op. cit., pp. 132-133

${ }^{307}$ NeIL MACCORMICK. Argumentação... op. cit., p. 135.

${ }^{308}$ NeIL MACCORMICK. Argumentação... op. cit., pp. 144-155.

${ }^{309}$ NeIL MACCORMICK. Argumentação... op. cit., pp. 197-198. 
as circustâncias fáticas forem outras, são facilitadas à medida que as diversas experiências jurídicas - advindas de textos legais, regulamentares, institucionais (vinculantes ou não a determinado caso), de decisões judiciais ou não judiciais - permitem uma antevisão dos efeitos que a norma proposta pelo intérprete irá gerar e da sua coerência e coesão com o sistema jurídico que rege um particular procedimento arbitral. Assim, quanto mais ampla a coleta de experiências feitas pelo intérprete e quanto mais pontos de contato ele consiga estabelecer entre essas experiências e o caso que quer solucionar, mais completa será a análise das premissas de estrutura e das premissas de conteúdo e, portanto, mais justificada estará a norma que ele propõe construir.

\subsection{O ambiente institucional no qual se desenvolve a arbitragem}

A finalidade de se coibir a parcialidade - fechamento do árbitro a ser influenciado pelos argumentos apresentados no processo por ambas as partes - deve ser buscada por um meio (disposto pela norma concreta proposta pelo intérprete) aplicado a um contexto no qual a arbitragem se desenvolve. À luz desse contexto, o meio ou norma não deve ser tal que dificulte sobremaneira a conclusão de parcialidade nos casos concretos, constituindo ferramenta útil para impedir que continuem figurando como árbitros aqueles profissionais aparentemente incapazes de produzir um julgamento imparcial. Essa perspectiva privilegia o devido processo legal. Em polo oposto, à luz desse mesmo contexto no qual a arbitragem se desenvolve, o meio ou norma para a coibição da parcialidade não pode facilitar sobremaneira a conclusão da sua existência, pois isso levaria à instabilidade do processo arbitral e à utilização da norma como técnica dilatória pela parte que quer tumultuar determinado procedimento arbitral ou anular sentença arbitral proferida legitimamente. Essa perspectiva privilegia a segurança jurídica.

No contexto descrito, a análise das premissas de conteúdo deve ser precedida pelo conhecimento do ambiente institucional no qual se desenvolve a prática da arbitragem, justamente para conferir maior uniformidade à identificação do nível de aparência ensejado pelos eventos do mundo concreto que se quer regular, equilibrando as exigências relativas ao devido processo legal e à segurança jurídica. 
Analiticamente, o conhecimento do ambiente institucional no qual se desenvolve a prática da arbitragem é imprescindível para ao menos três movimentos: (i) possibilitar a criação da norma concreta pela interpretação adequada dos padrões de comportamento eventualmente estabelecidos em textos normativos vinculantes; ou (ii) possibilitar a criação da norma concreta a partir do estado de coisas (quando inexistente previsão do padrão de comportamento) objetivado pelos textos normativos vinculantes; e, em qualquer dos casos anteriores, (iii) possibilitar o adequado enquadramento do evento do mundo fático nas categorias (padrões, quando previstos; comportamentos voltados à obtenção do estado de coisas, quando não houver previsão) da norma concreta proposta pelo intérprete.

A norma concreta deve respeitar tanto os postulados interpretativos do sistema jurídico (ou, dito de outro modo, sua coesão e sua coerência), quanto manter conexão com o mundo social no qual é desenvolvido o comportamento que se pretende regular normativamente $^{310}$. Realmente, se não conhecido o ambiente institucional dentro do qual atuam os praticantes da arbitragem, o intérprete correrá o risco de propor uma norma concreta que teria como consequência a decretação da parcialidade do árbitro em razão de um comportamento comum ou aceitável nesse ambiente institucional, porém, para ele (intérprete) desconhecido, tal como se daria pelo agendamento de entrevista do profissional pela parte estrangeira que considera nomeá-lo como árbitro ${ }^{311}$. Dado o seu desconhecimento do ambiente institucional, o intérprete poderia ser levado a crer que a

\footnotetext{
${ }^{310}$ Sobre o tema, vide capítulo 3.2.2 do presente estudo.

${ }^{311}$ Dada a ampliação dos candidatos à função de árbitro em arbitragens internacionais e o desconhecimento, pelas partes (geralmente estrangeiras), do perfil desses candidatos, a prática da entrevista é aceita. Sobre o tema, com instruções detalhadas sobre o que é e o que não é aconselhável perguntar ao candidato a árbitro segundo diversas instituições e autores, vide ChARTERED InstITUTE OF ARBITRATORs. Practice Guideline 16: the interviewing of prospective arbitrators, disponível no endereço eletrônico http://www.ciarb.org/information-and-resources/Practice\%20Guideline\%2016\%20April2011.pdf; consulta em 21.02.2014. A prática da entrevista, que geralmente envolve o advogado da parte, também é tratada na orientação $\mathrm{n}^{\circ} 8$ das IBA Guidelines on Party Representation in International Arbitration, lançadas em 25.05.2013, disponíveis no endereço http://www.ibanet.org/Publications/publications_IBA guides_and free materials.aspx\#partyrep; consulta em 21.02.2014. Na prática experiência jurídica interna norte-americana, a concepção do árbitro não neutro pode permitir a comunicação direta e troca de pontos de vista entre a parte e o árbitro por ela escolhido até mesmo após a instauração do processo arbitral. No caso Sunkist, mesmo após constatar a ocorrência de reuniões do árbitro (Jessie Meyers) com os patronos da parte (Del Monte) que o nomeou para a entrevista de testemunhas prospectivas do caso, a Corte do Décimo Primeiro Circuito não considerou prejudicada a imparcialidade do árbitro porque nem os representantes, nem as testemunhas estavam sob juramento nesse momento e porque não restou comprovado que o árbitro tivesse discutido com os demais as informações que recebeu durante as entrevistas, apontando que "Mr. Meyers' conduct is not only unobjectionable, but commonplace". Caso Sunkist Soft Drinks, Inc. et al. v. Sunkist Growers, 10 F.3d 753 (11th Cir. 1993). Decisão disponível no endereço eletrônico http://openjurist.org/10/f3d/753/sunkist-soft-drinks-inc-v-sunkistgrowers-inc; consulta em 21.02.2014.
} 
comunicação direta da parte com o potencial árbitro ensejaria, per se, a aparência de preferência do árbitro pela parte que o entrevistou e de vedação desse mesmo profissional aos (futuros) argumentos da parte contrária. De modo análogo, o desconhecimento do ambiente institucional pelo intérprete ensejará o risco de este propor norma concreta que tem como consequência a não decretação de parcialidade do árbitro por um comportamento reprovável, mas que ele, intérprete, venha a entender como um pecado menor, tal como se daria se, na entrevista do exemplo anterior, a parte revelasse as questões principais do caso e os argumentos que entende adequados para que o possível árbitro opinasse sobre eles. Afinal, se a entrevista é para conhecer o árbitro, por que não conhecer a sua opinião sobre o caso concreto ${ }^{312}$ ?

Outro exemplo da relevância do ambiente institucional pode ser extraído da publicação de artigos doutrinários em revistas científicas. Se a posição defendida teoricamente pelo potencial árbitro puder ser aproveitada favoravelmente por uma das partes em futuro litígio, esse evento do mundo fático poderia ser (erroneamente) tomado pelo intérprete que não conhece o ambiente institucional da arbitragem como indicativo de parcialidade, sob a presunção de que o árbitro tenderá a proferir sentença conforme a sua inclinação científica. Ora, entre o entendimento em tese a respeito de uma teoria jurídica e a sua aplicação em concreto em um conflito medeiam tanto a demonstração da aplicabilidade da teoria dentre outras igualmente aplicáveis (solução de questões de direito), quanto a demonstração da ocorrência dos eventos que permitiriam essa aplicação (solução de questões de fato). $\mathrm{O}$ exemplo e a conclusão se alterariam completamente se, ao invés de defender uma posição teórica, o árbitro, antes de ter sido nomeado, houvesse escrito texto técnico no qual criticasse uma sentença arbitral pretérita relativa à mesma relação jurídica material ${ }^{313}$, ou

\footnotetext{
${ }^{312}$ Esse é o ponto colocado por Craig e outros, para quem "it is perfectly proper for a party to discuss the case with the potential arbitrator", embora, curiosamente, esses mesmos autores apontem que o potencial árbitro deva apenas ouvir a parte, sem dar a sua opinião sobre o caso. W. LAWRENCE CRAIG; WILLIAM W. PARK; JAN PAULSSON. International Chamber of Commerce arbitration. 3. ed. Oceana Publications, 2000, p. 213. Atualmente, as orientações relativas à entrevista do árbitro na arbitragem internacional encontram-se na Guideline $\mathrm{n}^{\circ} 8$ das IBA Guidelines on Party Representation, disponíveis no endereço eletrônico http://www.ibanet.org/Publications/publications_IBA_guides_and_free_materials.aspx\#partyrep; consulta em 21.02.2014.

${ }^{313}$ Foi o que ocorreu no caso Swiss International Air Lines Ltd. v. Swiss Pilots Association (decisão 4P.247/2006, de 07.11.2006), decidido pela Suprema Corte da Suíça. As partes em questão já vinham litigando em duas outras arbitragens, já terminadas. Sobre a sentença da segunda arbitragem, um professor publicou um artigo, no qual, tomando por referências as questões de fato e de direito reveladas, apresentava opinião conclusiva sobre o mérito da causa. Posteriormente, esse professor foi indicado como árbitro por uma das partes para uma terceira arbitragem, sobre a mesma relação jurídica. Impugnado, o árbitro foi afastado pela Suprema Corte da Suíça, que considerou que as questões a serem colocadas para o professor seriam as
} 
se o árbitro também fosse advogado em uma causa essencialmente análoga, na qual a sua sentença servisse de precedente para reforçar a tese que, como advogado, o profissional defende ${ }^{314}$.

Em grande medida, portanto, conhecer o ambiente institucional da arbitragem pressupõe a tomada de consciência de que ela é praticada por profissionais que atuam em um mercado ${ }^{315}$ e que cultivam e mantêm relações entre si, com seus clientes e com terceiros, com o objetivo de, nesse mercado, prosperar $^{316}$.

\subsubsection{Um pouco da história da arbitragem comercial internacional ${ }^{317}$ e a arbitragem no Brasil: o aumento do número de árbitros e a ineficácia de controles informais}

Consta que até o início do século $\mathrm{XX}$ era corrente o entendimento a respeito da desnecessidade de controles formais para a regulação da conduta dos árbitros e das partes na arbitragem comercial internacional, pois se considerava que as qualidades $\mathrm{e}$ características dos envolvidos configurariam o fator-chave para a estabilidade da

mesmas que ele havia analisado em seu estudo, bem como que as críticas endereçadas pelo professor à sentença arbitral haviam sido contundentes e levariam à conclusão de que sua opinião não era mais passível de alteração. Maiores referências ao caso podem ser encontradas nos comentários de GEORG NAEGELI; HANNAH BOEHM. Swiss Federal Supreme Court upholds challenge of an arbitrator (Decision 4P.247/2006 dated 7 November 2006; published in DFC 133 I 89), in IBA Arbitration Committee newsletter, outubro de 2007, pp. 62-64.

${ }^{314}$ Trata-se do caso Telekom Malaysia, que envolveu o Prof. Emmanuel Gaillard, tratado na p. 156 do presente estudo.

${ }^{315}$ Considerando a existência de um mercado constituído por profissionais com credibilidade, prestígio e atuação habitual, bem como apontando a existência de incentivos institucionais (participação em lista de árbitros de instituições arbitrais e recusa de confirmação da sua nomeação) e mercadológicos (responsabilização do árbitro) para a atuação ética do árbitro, SUSAN D. FRANCK. The role of international arbitrators, in International law students association journal of international \& comparative law, v. 12, 2006, pp. 516-518.

316 "[A]rbitration is now a service industry, and a very profitable one at that. The arbitral institution, the arbitrators, the lawyers, the expert witnesses and the providers of ancillary services all charge fees on a scale which would quite literally have been inconceivable thirty years ago". MICHAEL MUSTIL. Arbitration: history and background, in Journal of international arbitration, v. 6, n. 2, 1989, p. 55.

${ }^{317}$ Embora a arbitragem internacional não seja uma categoria qualificada normativamente na lei brasileira, não se pode negar que há uma prática internacional da arbitragem, sobretudo ligada aos conflitos derivados do comércio transnacional; prática que, nesse sentido, distingue-se daquela desenvolvida na arbitragem de direito interno. Sobre o tema, sucintamente, LUIZ OlAVo BAPTISTA. Arbitragem... op. cit., p. 39. 
arbitragem: o senso de honra e o temor de reprovação ensejariam nas partes ${ }^{318}$ - homens de negócio, em sua maioria - pressão suficiente para o cumprimento voluntário das sentenças arbitrais, tornando desnecessárias regras para o cumprimento judicial dessas decisões; o mesmo senso de honra e o temor de reprovação ensejariam nos árbitros juristas europeus renomados, em sua maioria - pressão suficiente para conduta ética e imparcial, tornando desnecessária regulação normativa nesse sentido, mesmo no âmbito da $\mathrm{CCI}^{319}$.

Com o desenvolvimento do comércio internacional e o consequente aumento das disputas nesse campo, a crença de que o mero senso de honra seria suficiente para compelir as partes ao cumprimento das sentenças arbitrais foi sendo abandonada e substituída pela convicção da necessidade de uma regulação normativa mínima que propiciasse segurança e efetividade ao seu cumprimento ${ }^{320}$. Eis a origem da moderna arbitragem comercial internacional, que nasceu do esforço originalmente empreendido entre os anos de 1930 e 1950 por um grupo de juristas europeus relativamente restrito, posteriormente denominado "grand old men" 321 . Seu projeto - configurar um sistema operativo para a solução de conflitos ligados ao comércio internacional - culminou, no ano de 1958, com a elaboração da Convenção para o Reconhecimento e a Execução de Sentenças Arbitrais Estrangeiras, também conhecida como Convenção de Nova York ${ }^{322}$. No entanto, a preocupação com a

\footnotetext{
${ }^{318}$ DETLEV F. VAGTS. The international legal profession: a need for more governance?, in American journal of international law, v. 90, 1996, p. 250.

${ }^{319}$ W. LAWRENCE CRAIG. Some trends and developments in the laws and practice of international commercial arbitration, in Texas international law journal, v. 30, 1995, p. 7.

${ }^{320}$ No Report and Preliminary Draft Convention adopted by the Committee on International Commercial Arbitration at its meeting of 13 March 1953, promovido pela Câmara de Comércio Internacional, são registradas as críticas debatidas ao sistema então vigente, regulado pela Convenção de Genebra de 1927, e a sua insuficiência para a ordem econômica internacional da época, notadamente no que diz respeito ao cumprimento de sentenças arbitrais estrangeiras. É clara, nesse sentido, a superação do ideal de senso de honra para o cumprimento de sentenças arbitrais. Vide COMMITTEE ON INTERNATIONAL COMMERCIAL ARBITRATION. Report and Preliminary Draft Convention adopted by the Committee on International Commercial Arbitration at its meeting of 13 March 1953, in ICC Publication, n. 174, 1953, p. 7 [=The ICC International Court of Arbitration Bulletin, v. 9, 1998].

${ }^{321}$ A expressão foi difundida pela obra de Yves DaZALAY; BRYANT G. GARTH. Dealing... op. cit., pp. 34-37. No mesmo sentido, e com detalhes históricos, CATHERINE A. Rogers. The vocation ... op. cit., pp. 963-964.

322 Thomas E. Carbonneau, The Ballad... op. cit., p. 774. Alguns desses "grand old men" ou "grand notables", diretamente envolvidos com o desenvolvimento da arbitragem internacional e com a elaboração do texto que deu origem à Convenção de Nova Iorque, são nominados por Pieter Sanders e têm seu papel descrito por Ottoarndt Glossner, também participantes do esforço normativo. Vide, para tanto, PIETER SANDERS. The making of the Convention, in Enforcing arbitration awards under the New York Conventionexperience and prospects, New York: United Nations, 1999, p. 3 e OTTOARNDT GLOSSNER, From New York (1958) to Geneva (1961) - a veteran's diary, in Enforcing arbitration awards under the New York Convention - experience and prospects, New York: United Nations, 1999, pp. 5-7.
} 
regulação normativa do cumprimento das sentenças arbitrais não foi acompanhada pela regulação da conduta dos árbitros, pois, a despeito do crescente aumento do número de litígios no âmbito do comércio internacional, seu número ainda permitia que um seleto grupo de profissionais suficientemente qualificados continuasse a dominar a atividade de patrocínio das causas e, por consequência, da escolha e do exercício da função de árbitros $^{323}$.

Diante do acentuado incremento do comércio internacional e do surgimento de diversos outros atores nesse campo ${ }^{324}$, os controles informais - aos quais se submetiam os membros do relativamente pequeno seleto grupo de pessoas elegíveis ao papel de árbitros nos conflitos do comércio internacional - deixaram de ser eficazes. De um lado, o aumento no volume dos conflitos demandou o aumento do número de julgadores ${ }^{325} \mathrm{e}$, de outro, a ampliação do comércio internacional ensejou a entrada de diversos atores (de distinta origem e formação jurídico-cultural) no panorama da arbitragem internacional, aumentando a diversidade cultural e jurídica dos profissionais dedicados à atividade ${ }^{326}$.

A participação de agentes com diferentes bagagens jurídico-culturais na arbitragem internacional e o vertiginoso aumento no número de conflitos ensejaram a perda da homogeneidade pretérita a respeito do que consistiria a conduta do árbitro considerada imparcial, bem como dos controles informais característicos dos pequenos grupos ${ }^{327}$. A

\footnotetext{
${ }^{323}$ Catharine Rogers chama a atenção para o fato de que a Convention on the Recognition and Enforcement of International Arbitral Awards de 1958 (Convenção de Nova York) não menciona quaisquer qualificações mínimas para árbitros ou quaisquer consequências para a ausência de imparcialidade dos árbitros. CATHARINE A. Rogers. Regulating... op. cit., p. 78.

324 "New entrants also came from the United States as American companies began participating more vigorously in international trade and American law firms took note of the large profits to be made in providing international arbitration services. Both groups eventually introduced to the system 'home-grown' arbitrators, who better reflected their own expectations and legal cultures". CATHERINE A. ROGERS. The vocation... op cit., p. 4.

325 Com informações estatísticas, vide ELENA V. HELMER, International commercial arbitration: americanized, "civilized", or harmonized?, in Ohio State journal on dispute resolution, v. 19, n. 1, 2003, p. 38.

${ }^{326}$ Dezalay e Garth apontam a entrada de grandes bancas norte-americanas na prática da arbitragem internacional, as quais levaram o seu conhecimento técnico (ou tecnocrático, segundo os autores) processual - sobretudo em matéria de conflito de interesses -, utilizando-o para quebrar a hegemonia dos "grand old men", que eram experts em direito material e que mantinham grande proximidade entre si. YVES DAZALAY; Bryant G. GARTH. Dealing... op. cit., pp. 47 e 205-212. No mesmo sentido, CATHARINE A. Rogers. Regulating... op. cit., pp. 62-63.

${ }^{327}$ Literalmente: "The small community of international arbitrators, who know and trust one another, is gone. Peer-group control will no longer be here to preserve the 'ethics' of international arbitration." DAVID
} 
arbitragem - especialmente na função de árbitro - deixou de ser área de atuação exclusiva dos "grand notables" 328 , embora seja possível notar a existência de uma elite de profissionais altamente qualificados que predominam nas arbitragens de maior vulto financeiro e de maior importância ${ }^{329}$.

Embora haja movimentos orientados à convergência de práticas na arbitragem comercial internacional $^{330}$ (a exemplo das Guidelines das IBA sobre conflitos de interesses ou sobre a conduta dos representantes na arbitragem internacional ou das Rules dessa instituição a respeito da produção de provas ${ }^{331}$ ), eles estão longe de terem se completado ou mesmo de contarem com o apoio de todos os estudiosos e praticantes da arbitragem ${ }^{332}$. As práticas ainda divergem de acordo com as diversas experiências e os diversos ambientes institucionais em que a arbitragem se desenvolve.

$\mathrm{Na}$ esfera nacional, a Lei $\mathrm{n}^{\circ}$ 9.307/1996 entrou em vigor e foi referendada pelo Poder Judiciário quando já estava amplamente superada a confiança no senso de honra das partes, e em momento em que já se despertava, na prática e na doutrina estrangeiras, a preocupação com a imparcialidade dos árbitros ${ }^{333}$. Tal como ocorreu e ainda ocorre no cenário internacional, a utilização do método é cada vez mais frequente nas arbitragens

HACKING. Ethics, elitism, eligibility: a response: what happens if the icelandic arbitrator falls through the ice?, in Journal of international arbitration, v. 15, n. 4, 1998, p. 77.

${ }^{328}$ Yves DAZALAY; BRYANT G. GARTH. Dealing... op. cit., p. 306.

329 Thomas Clay. Quem são os árbitros internacionais. Abordagem sociológica, in Revista de arbitragem e mediação. v. 6, 2005, p. 109. Yves DAZALAY; BRYANT G. GARTH. Dealing... op. cit., pp. 35

${ }^{330}$ Explicando essa convergência com base na noção econômica de rede (“network"), pela qual a comunhão de uso reduz os custos de interação entre os sujeitos e agentes da arbitragem internacional, o que impulsiona indivíduos, instituições arbitrais e até mesmo Estados a adotarem práticas cada vez mais comuns, vide ToM GINSBURG. The culture of arbitration, in Vanderbilt jornal of transnational law, v. 36, 2003, pp. 1342-1343. Sobre o papel da soft law nessa convergência, vide ANDRÉ DE ALBUQUERQUE CAVALCANTI ABBUD. A soft law... op. cit., passim.

331 Textos no endereço eletrônico http://www.ibanet.org/Publications/publications_IBA_guides_and_free_materials.aspx; $\quad$ consulta em 21.02.2014.

${ }^{332}$ Sobre o assunto, comparando práticas do ambiente institucional europeu e norte-americano da arbitragem, CARRIE MENKEL-MEADOW Are cross-cultural ethics standards possible or desirable in intenational arbitration?, in Mélanges en l'honneur de Pierre Tercier. Zurich: Schulthess Verlag, 2008, p. 897-898. Sobre a oposição às IBA Guidelines on Party Representation, vide as duras palavras do presidente da Associação Suíça de Arbitragem, MICHAEL E. SCHNEIDER. Transfer of ownership: from the parties' respective cases to the Case decided by the tribunal, disponível no endereço eletrônico http://www.arbitration-ch.org/pages/en/asa/news-\&-projects/presidentsmessage/index.html\#.UxKnWbWYZMt; consulta em 21.02.2014.

${ }^{333}$ A constitucionalidade da LA foi declarada pelo STF no processo de homologação de sentença estrangeira de autos SE 5.206, em outubro de 2001. 
internas brasileiras ${ }^{334}$, gerando demanda por mais árbitros (a despeito da existência de uma elite de profissionais brasileiros que figuram como árbitros nos conflitos mais relevantes, tal como se pode verificar nas listas de árbitros das principais instituições arbitrais, nas publicações e nos congressos dedicados ao assunto ${ }^{335}$ ) e, consequentemente, de orientações mais claras a respeito do sentido e alcance da imparcialidade que lhes é prescrita.

\subsubsection{A prática arbitral e seu desenvolvimento em um mercado assimétrico}

Não há dúvidas de que a prática da arbitragem ensejou a formação de um conjunto de profissionais especializados nesse método de solução de controvérsias: além do reconhecimento entre seus pares, árbitros, advogados das partes, pareceristas e outros prestadores de serviços jurídicos, estão a atuar em um campo que impõe desafios profissionais, geralmente envolve altas somas de dinheiro e pode proporcionar polpudos honorários ${ }^{336}$. Assim, a procura dos agentes econômicos em situação de conflito pela prestação de serviços jurídicos ligados à arbitragem e a oferta desses mesmos serviços pelos profissionais da área possibilita a constituição de um verdadeiro mercado profissional $^{337}$.

A despeito da expansão do número de profissionais disponíveis para atuar como árbitros nas arbitragens internacionais e, em menor grau, nas arbitragens internas ${ }^{338}$, há dois fatores

\footnotetext{
${ }^{334}$ Vide, exemplificadamente, o número de litígios submetidos anualmente à CMA CIESP/FIESP, que aumentou de 5 no ano de 2001 para 39 no ano de 2012. Revista direito ao ponto, ano 6, n. 8, p. 53.

${ }^{335}$ Vide os recorrentes palestrantes, debatedores e oradores dos eventos patrocinados pelo CBAR nos anos de 2000 a 2013, cujos dados podem ser consultados no endereço eletrônico http://cbar.org.br; consulta em 21.02.2014.

${ }^{336}$ Crescimento da arbitragem cria novo mercado para advogados. Fonte: Jornal Valor Econômico, caderno "Legislação \& Tributos", 08.08.2003, p. E-1.

337 "Em sentido geral, o termo [mercado] designa um grupo de compradores e vendedores que estão em contato suficientemente próximo para que as trocas entre eles afetem as condições de compra e venda dos demais. Um mercado existe quando compradores que pretendem trocar dinheiro por bens e serviços estão em contato com vendedores desses mesmos bens e serviços. Desse modo, o mercado pode ser entendido como o local, teórico ou não, do encontro regular entre compradores e vendedores de uma determinada economia". PAUlo SANDRONI. Novíssimo dicionário de economia. São Paulo: Best Seller, 1999, p. 378.

${ }^{338}$ Em obra que se volta ao esclarecimento, ao empresário ou ao advogado não familiarizado com o mundo da arbitragem, é registrado que até mesmo orientações a respeito da imparcialidade, aplicáveis nas arbitragens internacionais, não o seriam nas arbitragens internas "porque no Brasil o mundo da arbitragem ainda é muito pequeno". O próprio título da obra já é um indicativo da existência de informações não
} 
principais que impedem a formação de um mercado competitivo e aberto: $(i)$ as barreiras à entrada de novos profissionais; e (ii) a assimetria de informação dentro desse mercado ${ }^{339}$.

As barreiras à entrada são determinadas pelo número não relevante de profissionais dedicados à arbitragem, que mantêm a sua posição no mercado pelas credenciais que ostentam ou, mais precisamente, pelo uso de um "capital simbólico"340 agregado em três frentes: $(i)$ detenção de um saber específico no campo do direito processual ou do direito material envolvido nos conflitos; (ii) manutenção de relações negociais e sociais que os envolvam nos centros de prática da arbitragem; e (iii) o reconhecimento entre os seus pares $^{341}$.

Como o método mais comum de composição de um tribunal arbitral é a nomeação unilateral de um coárbitro para cada uma das partes (ou, nas arbitragens multipartes, por um dos pólos da relação processual), é comum que tais partes - com apoio dos seus advogados - escolham para a função os profissionais que se destacarem no ofício de árbitro e que, obviamente, tenham para com a causa alguma afinidade - evitando-se, no entanto, julgador claramente venal, visto que isso reduziria consideravelmente a possibilidade de ele influenciar o julgamento do tribunal arbitral ${ }^{342}-$, com preferência àqueles que já tenham, em algum momento das suas carreiras, emitido opinião (em textos, sentenças ou palestras, além de outras oportunidades) que possa, ao menos em princípio, favorecer a tese que a parte indicante irá defender na arbitragem. A seleção do árbitro é orientada à maximização das chances de procedência das teses da parte que o escolhe,

disponíveis aos profissionais não iniciados nesse mundo. HAROLDO MALHEIROS DUCLERC VERÇOSA. Os “segredos" da arbitragem. São Paulo: Saraiva, 2013, p. 71.

${ }^{339}$ CATHERINE A. RogERS. The vocation... op. cit., pp. 967-968.

340 YVes DaZalay; Bryant G. Garth. Dealing... op. cit., pp. 29 e 31.

${ }^{341}$ ThOMAS ClAY. Quem são... op. cit., p. 109.

${ }^{342}$ Em termos diretos: "This, however, is not the complete picture. In reality, parties afforded the power to appoint an adjudicator do hope to impact the final outcome of the adjudicatory process through appointing a person sympathetic to them or their case. To think otherwise would be absurd. If nothing else, classic 'prisoner dilemma' dynamics, the fear that the other party would appoint a favorable adjudicator, would lead to such an outcome. Even when viewed from this perspective, judicial independence and impartiality may still have a certain strategic value. A party-appointed adjudicator may be more effective in terms of impacting the outcome of the adjudicatory process if she is perceived as independent and impartial". YUVAL SHANY. Squaring the circle? independence and impartiality of party-appointed adjudicators in international legal proceedings, in Loyola of Los Angeles international and comparative law review, v. 30, n. 3, 2008, p. 482. Sobre a atitude tomada por profissionais de renome quando participam de painel em que um dos membros demonstra franco favoritismo pela parte que o nomeou, vide ANDREAS F. LOWENFELD, The partyappointed arbitrator: further reflections, in LAWRENCE W. NEWMAN; RICHARD D. HILL (Ed.). The leading arbitrators' guide to international arbitration. 2. ed. New York: Juris Publishing, 2008, pp. 43-45. 
envolvendo a análise das atividades anteriores do árbitro, os tribunais em que ele desempenhou função, a personalidade, o fato de ele já ter servido com os árbitros ou advogados em outro painel, entre outros fatores ${ }^{343}$, atividade que aparentemente dá resultado, bastando verificar o número de decisões divergentes nos processos arbitrais ICSID, proferidas pelos coárbitros em favor da parte que os escolheu ${ }^{344}$. Uma conhecida afirmação de um também conhecido profissional da arbitragem internacional deve ser sempre levada em consideração: "quando patrocino um cliente em uma arbitragem, procuro escolher um árbitro com a máxima predisposição ao meu caso, com o mínimo de aparência de parcialidade,

Para o profissional da área jurídica ser conhecido, ele precisa se projetar, participando do máximo de atividades ligadas ao tema da arbitragem. Essas atividades certamente motivarão a criação de contatos que, se não compreendidos dentro da lógica do ambiente institucional, poderão ser interpretados como causadores de parcialidade. Um jantar oferecido por um profissional aos diversos palestrantes durante um congresso não deverá ensejar a aparência de parcialidade se, posteriormente, um dos convidados, na qualidade de patrono de uma das partes, indicar o anfitrião como árbitro; totalmente diferente seria a situação se esses personagens (árbitro e advogado) jantassem sozinhos, em um evento não institucional e aparentemente sem outra motivação profissional ${ }^{346} 347$. No Brasil, a conjunção de um mercado ainda composto por número não expressivo de profissionais dedicados à função de árbitro (que permite que eles se conheçam e sejam conhecidos e

\footnotetext{
${ }^{343}$ DOAK BISHOP; LuCY REED. Practical... op. cit., p. 399. Também de modo claro: "The reality is that everything a party does once a dispute has broken out is focussed on winning." JAN PAULSSON. Moral ... op. cit., p. 10.

${ }^{344}$ ALBERT JAN VAN DEN BERG. Dissenting opinions by party-appointed arbitrators in investment arbitration, in MAHNOUSH H. ARSANJANI et al. (Ed.). Looking to the future: essays on international law in honor of W. Michael Reisman, Amsterdam: Martinus Nijhoff, 2010, pp. 821-843.

${ }^{345}$ No original: "[W]hen I am representing a client in an arbitration, what I am really looking for in a partynominated arbitrator is someone with the maximum predisposition towards my client, but with the minimum appearance of bias". MARTIN HUNTER. Ethics of the International Arbitrator. Trecho transcrito por SIMON GREENBERG; CHRISTOPHER KEE; J. ROMESH WEERAMANTRY. International commercial arbitration: an Asia Pacific perspective. New York: Cambridge University Press, p. 263.

${ }^{346} \mathrm{O}$ membros da comunidade arbitral "purport to regulate its activity through sets of internal rules and ethical mores. At the same time, those outside the regulated group maintain a strong interest in the observance of ethical guidelines that are consistent with societal notions of fairness and honesty. Thus, even the ethical structures and boundaries of self-regulating professions are continually measured against larger societal goals and ideals, including neutrality". DESERIEE A. KENNEDY. Predisposed with integrity: the elusive quest for justice in tripartite arbitrations, in Georgetown journal of legal ethics, v. 8, 1994, p. 750.
}

${ }^{347}$ Colocando que esse evento ensejaria aparência de parcialidade no ambiente institucional norte-americano, em contraste ao europeu, CARRIE MENKEL-MEADOW. Are cross-cultural... op. cit., pp. 897-898. 
respeitados - ou ao menos não impugnados - pelos advogados das partes), bem como a cordialidade $^{348}$ característica da índole do brasileiro ainda possibilitam que, na prática, essa situação de encontros e jantares entre profissionais ainda sejam comuns. Isso, no entanto, deve se alterar para que o ambiente institucional brasileiro alcance um padrão de conduta mais condizente com a prática internacional ${ }^{349}$.

Contatos profissionais e sociais existem no ambiente institucional da arbitragem. E essa realidade - que significa que árbitros em potencial e advogados podem ser colegas, mas não comparsas; podem ser conhecidos, mas não aliados - deve ser reconhecida e levada em conta pelo intérprete quando da formulação da norma concreta que ele quer ver $\operatorname{aplicada}^{350}$.

Assim, é de se esperar que haja algum nível de interação entre profissionais que ora figuram como árbitros, ora como advogados. Não se pode, de antemão, apontar aparência de imparcialidade ao árbitro que participa de uma mesma instituição acadêmica ou profissional que o advogado de uma das partes - até porque são esses contatos profissionais ou acadêmicos os gatilhos que lhes podem render nomeações para a composição de um tribunal arbitral -, ou se o árbitro fizer a apresentação de livro escrito pelo advogado de uma das partes ${ }^{351}$. Veja-se, por exemplo, o caso decidido pela Corte Superior Regional (“Oberlandesgericht”) de Frankfurt, no qual não foi reconhecida a parcialidade do árbitro que, na qualidade de diretor da DIS ("Deutsche Institution für Schiedsgerichtsbarkeit”) e um dos três coeditores de publicação periódica da entidade,

\footnotetext{
${ }^{348}$ A expressão, no sentido definido por Buarque de Holanda, aponta para a aversão do brasileiro a ritualismos e sua preferência por forma de convívio ditada por ética de fundo emotivo, originada do meio rural e patriarcal. SÉRGIO BUARQUE DE HolANDA. O homem cordial, in Raízes do Brasil. 26. ed. São Paulo: Companhia das Letras, 1995, pp. 146-148.

${ }^{349}$ Apontando que, no que diz respeito às práticas das diversas comunidades arbitrais, "the main mechanisms of convegence are likely to be economic rather than cultural", TOM GINSBURG. The culture... op. cit., p. 1345.

350 "Many think that the Judicial Code of Conduct, since where lawyers lay adjudicative roles. I do not agree, since the judge has a permanent role, which allows him to be at arms length from parties on a regular basis. Arbitrators who may depend on parties choosing and paying them may be closer to lawyers seeking clients in some respects, while resembling judges in others". CARRIE MENKEL-MEADOW. Ethics and professionalism in non adversarial lawyering, in Forida State University law review, v. 27, p. 161, nota de rodapé n. 49.

${ }^{351}$ Esse é o alerta dado no caso Health Services Management Corp. v. Charles Hughes, 975 F.2d 1253 (7th Cir. 1992) que, citando o caso Florasynth, Inc. v. Pickholz (750 F.2d 171, 173 - 2nd Cir.1984), fez constar que "[a]s arbitrators are usually knowledgeable individuals in a given field, often they have interests and relationships that overlap with the matter they are considering as arbitrators. The mere appearance of bias that might disqualify a judge will not disqualify an arbitrator". Decisão disponível no endereço eletrônico http://openjurist.org/975/f2d/1253/health-services-management-corp-v-hughes; consulta em 21.02.2014.
} 
havia cosubscrito o prefácio da edição publicada em setembro de 2006, dedicada às regras europeias de concorrência e arbitragem. Nessa edição, havia um texto que reproduzia uma conferência proferida pelo advogado do requerido na arbitragem, na qual era defendida a inexistência de poder-dever dos árbitros em investigar alegações de violação às regras europeias de concorrência. Após a veiculação da edição (janeiro de 2007), o tribunal arbitral informou às partes que encerraria a instrução sem ordenar investigações sobre o cumprimento das regras de concorrência que uma das partes alegou terem sido violadas, o que levou tal parte a impugná-lo por, indiretamente, endossar posição da outra parte a respeito do caso objeto da arbitragem, analogamente ao parágrafo 3.5 .2 das IBA Guidelines. A Corte Superior de Frankfurt julgou improcedente a impugnação do árbitro $^{352}$.

Dada a amplitude ainda restrita dos participantes do mercado da arbitragem e a proteção do seu capital simbólico, é comum que os coárbitros escolham como presidente do tribunal arbitral o profissional que conhecem e em quem, de certa foram, confiam. Tal confiança pode ser retribuída na escolha da presidência de outro tribunal futuro. Não só. Esses mesmos profissionais frequentemente trocam os papéis não apenas na constituição dos tribunais arbitrais, mas também quando um deles é o advogado de uma das partes e nomeia outro profissional do grupo para a função de coárbitro ${ }^{353}$. Assim, e em certa medida, também participam do ambiente institucional da arbitragem as partes que frequentemente se utilizam do método para a solução de suas disputas, tais como grandes construtoras, grandes agentes do comércio internacional etc. ${ }^{354}$ Quanto mais restrito o mercado, mais se pode admitir a existência de contatos entre parte e árbitro, conforme se decidiu no caso

\footnotetext{
${ }^{352}$ Comentários e maiores referências ao caso podem ser consultados em MATTHIAS SCHERER. New case law from Austria, Switzerland and Germany regarding the IBA Guidelines on Conflicts of Interest in International Arbitration, in Transnational dispute management, v. 5, , n. 4, 2008, pp. 11-12; disponível no endereço eletrônico http://www.lalive.ch/files/Scherer-IBA_Guidelines-case_law.pdf; consulta em 21.02.2014

${ }^{353}$ Literalmente: "[t]he same individuals who belong to the networks around the central institutions of arbitration are found in the roles of lawyers, co-arbitrators, or chairs of the arbitral tribunal. The principal players therefore acquire a great familiarity with each other, and they develop also, we suspect, certain connivance with respect to the role held by the adversary of the moment." YVES DAZALAY; BRYANT G. GARTH. Dealing... op. cit., p. 49.

${ }^{354}$ Daí se afirmar que: "There is a tradeoff between impartiality and expertise. The expert adjudicator is more likely than a judge or juror not only to be precommitted to a particular substantive position but to know or have heard of the parties (or if the parties are organizations, their key people)." Caso Merit Insurance Company v. Leatherby Insurance Company, 714 F.2d 673 (7th Cir. 1983), disponível no endereço eletrônico https://www.casetext.com/case/merit-ins-co-v-leatherby-ins-co-2/; consulta em 21.02.2014. O presente estudo, ao conceituar diferentemente a imparcialidade, nega essa afirmação.
} 
Mutual Insurance v. Home Insurance, no qual a Corte de Apelação do Sexto Circuito confirmou a validade da sentença arbitral derivada em processo no qual a cláusula compromissória prescrevia que "the arbitrators come from within the insurance industry", de modo que as partes, no entender da referida Corte, deveriam estar conscientes da probabilidade de que os árbitros, como participantes do mercado, tivessem mantido relações pretéritas com os envolvidos, ou seja "the panel will contain some actual or potential friends, counselors, or business rivals of the parties." No caso em questão, Mutual buscou a anulação da sentença em razão de o árbitro indicado pela Home, Ronald Jacks, não ter cumprido com o dever de revelação, embora Ronald tenha prestado declaração, no início do procedimento, na qual informou ter participado de painéis como árbitro da Home seis vezes e como árbitro da sua adversária duas vezes nos últimos 20 anos, não tendo revelado que, quando trabalhava como advogado (Jacks era advogado aposentado), o escritório para o qual trabalhava havia patrocinado empresa ligada à Home, em representação que não havia perdurado ${ }^{355}$.

O reconhecimento entre os pares é o último dos fatores que atribuem a um determinado profissional o capital simbólico que lhe rende a nomeação para a composição de tribunais arbitrais. Quanto maior o reconhecimento, mais aceitação o profissional terá e, na prática, mais difícil será atribuir-lhe parcialidade em determinado caso. É esse reconhecimento que impede, por exemplo, que o profissional que tenha dado pareceres a clientes de uma banca de advocacia que patrocina uma das partes (não a beneficiária do parecer, obviamente) seja impugnado pela parte patrocinada pela banca adversária. É esperado que grandes juristas prestem serviços às grandes bancas, no papel de pareceristas. No entanto, a conclusão pode não ser a mesma se, ao invés de um jurista com décadas de atuação, estiver-se frente a um professor em início de carreira, visto que sua trajetória pode não ter rendido ainda o reconhecimento de seus pares a ponto de evitar que um contato profissional seja tomado como aparência de parcialidade.

O presente estudo não defende que a construção da norma concreta pelo intérprete leve em conta o reconhecimento profissional do árbitro impugnado. Ao contrário, a busca por alguma harmonização no que diz respeito à imparcialidade passa pelo tratamento equânime

${ }^{355}$ Caso Mutual Insurance Co. v. Home Insurance Co., 429 F.3d 640 (6 ${ }^{\text {th }}$ Cir. 2005). Decisão disponível no endereço eletrônico http://law.justia.com/cases/federal/appellate-courts/F3/429/640/494640/; consulta em 21.02.2014. 
dos profissionais. $\mathrm{O}$ que não se pode deixar de constatar é que, na prática, o reconhecimento do árbitro pelos seus pares pode servir como fator inibidor de impugnação, o que nada tem a ver com a modulação da norma concreta, caso ela venha a ser proposta pelo intérprete.

O reconhecimento também pode ser fator que dificulta a acusação de parcialidade ao árbitro, pois quanto mais conhecido ele for, mais informações públicas existirão sobre o seu entendimento a respeito de determinadas questões jurídicas e, igualmente, mais informações existirão a respeito da sua participação em instituições e eventos ligados à prática da arbitragem, sendo, por consequência, mais fácil perquirir a respeito das relações do árbitro com os demais agentes (partes ou advogados) de um procedimento específico. Assim, quanto mais informações públicas ou acessíveis às partes houver, mais emulativa se revelará eventual impugnação do árbitro (especialmente se tal impugnação for feita no momento final do procedimento e a sequência dos atos processuais puder levar à conclusão de que o julgamento será desfavorável à parte que apresenta a impugnação).

As assimetrias derivadas da existência de um grupo reduzido de profissionais dedicados à arbitragem são reforçadas pela confidencialidade dos procedimentos, que resulta na não publicação das sentenças e das decisões relativas às impugnações de árbitros ${ }^{356}$. Com isso, as informações sobre a reputação dos árbitros são de difícil acesso para os interessados, restando apropriada apenas pelos profissionais ou escritórios que atuam com frequência nesse mercado ${ }^{357}$.

Por último, a análise do ambiente institucional da arbitragem deve levar em conta os usuários desse método. Não se pode esquecer que a arbitragem - pela sua proposta de

\footnotetext{
${ }^{356}$ Apontando a confidencialidade dos processos arbitrais como uma das causas da assimetria no mercado da arbitragem, CATHERINE A. ROGERS. Regulating... op. cit., p. 65. Defendendo a aplicação de precedentes (no sentido de stare decisis) na arbitragem, Kuyven também defende que "deva ser dado aos centros de arbitragem maior autonomia para decidir sobre a utilidade e a oportunidade de publicar as decisões". LUIZ FERNANDO MARTINS KUYVEN. O necessário precedente arbitral, in Revista de Arbitragem e Mediação, v. 36, 2013, p. 307. Registre-se que entre as instituições que administram processos arbitrais no Brasil, o CAMCCBC e a CCMA-CIESP/FIESP já aprovaram a publicação de trabalhos que consolidem as decisões tomadas em âmbito interno (com supressão das identificações para manutenção do sigilo) relativas a pedidos de afastamento de árbitros.

${ }^{357}$ Literalmente: "Not surprisingly, there are potential difficulties in obtaining anecdotal information about arbitrator candidates. Some individuals and firms regard this information as confidential or proprietary; some limit the availability of this type of intelligence to a circle of close, professional friends or colleagues (...)". Francis O. SPALDING. Selecting the arbitrator, what counsel can do, referido por CATHERINE A. ROGERS. The vocation ... op. cit., p. 969.
} 
possibilitar o procedimento adequado a cada caso específico, a ser decidido por especialistas na matéria - não é desenhada para separar por completo o julgador da comunidade negocial a qual ele serviráa ${ }^{358}$.

A interpretação de regra ou a proposta normativa deve levar em conta, portanto, a existência de um ambiente institucional que proporciona uma maior interação e proximidade entre os potenciais árbitros, advogados e, porque não dizer, indivíduos e instituições que se utilizam com mais frequência desse método de solução de controvérsias.

\subsection{Premissas de conteúdo}

As premissas de estrutura não esgotam o trabalho do intérprete na elaboração da norma concreta a concluir pela parcialidade ou imparcialidade do árbitro. Elas servem como roteiro e ferramenta para que o intérprete componha a norma, mas pouco dizem sobre o seu conteúdo, ou melhor, sobre a hipótese de fato normativa. As premissas de estrutura orientam a construção do silogismo normativo, ao passo que as premissas de conteúdo o preenchem, fornecendo mais segurança e maior possibilidade de controle à produção da norma concreta.

São as premissas de conteúdo as categorias que o intérprete utilizará para ligar as situações e eventos do mundo fático (ou melhor, os elementos que quer destacar desses eventos e os juízos de valor a respeito deles) à consequência normativa que dê pela parcialidade ou imparcialidade do árbitro e respectivos efeitos jurídicos, estabelecendo toda a cadeia de microdecisões que levará à macrodecisão final ${ }^{359}$, integrando a norma concreta. Assim, trabalhando as premissas de conteúdo conforme as premissas de estrutura, o intérprete valorará eventos fáticos e normatizará a parcialidade ou imparcialidade no caso concreto.

\footnotetext{
${ }^{358}$ HENRY GABRIEL; ANJANETTE H. RAYMOND. Ethics for commercial arbitrators: basic principles and emerging standards, in Wyoming law review, v. 5, 2005, p. 454.

${ }^{359}$ RODOLFO LUIS VIGO. Interpretação... op. cit., p. 111.
} 
A prática jurídica permite que o presente estudo decante certas categorias de eventos que, investigadas analiticamente e trabalhadas à luz das premissas de estrutura, auxiliem a normatização da parcialidade ou imparcialidade através da aparência. Essas categorias não esgotam, obviamente, todas as infinitas variáveis fáticas possíveis. Ademais, por serem fruto da acumulação de experiência, as categorias propostas no presente estudo não obstam a que um mesmo evento do mundo fático seja decomposto e inscrito em mais de uma delas, fazendo com que, na prática, as categorias e respectivas investigações analíticas se sobreponham. Não obstante, tais categorias são úteis à tarefa do intérprete em construir a norma aplicável ao caso concreto, ao agregar eventos similares e homogeneizar os critérios pelos quais eles podem ser analisados.

De modo não exauriente, o presente estudo busca identificar, dentro da massa de casos nos quais a imparcialidade do árbitro foi questionada (respeitando-se, obviamente, o método de padronização da imparcialidade aplicado), as categorias de situações ou eventos mais comuns, que permitirão a identificação, para cada qual, dos respectivos critérios de análise.

Referida massa de casos pode ser submetida a uma primeira clivagem, da qual derivam três categorias primárias: (1) casos em que o questionamento da imparcialidade foi sustentado preponderantemente na existência de uma relação estabelecida entre o árbitro ou pessoas e entidades a ele ligadas com a parte ou pessoas e entidade a ela ligadas; (2) casos em que o questionamento da imparcialidade foi sustentado preponderantemente na existência de relação do árbitro com o advogado ou escritório de advocacia que patrocina a parte ou entidades a ela ligada; e (3) casos em que o questionamento não se encontra diretamente fundado nas relações preponderantes das categorias anteriores.

A categoria (1) admite decomposição com base na natureza da relação, abrindo dois ramos: (1.1) relação de negócios, que envolve liames primordialmente econômicos; e (1.2) relação familiar, pessoal ou social, que envolve outros liames que não os econômicos. Dentro da categoria (1.1), ainda um terceiro nível de decomposição é possível, dela derivando: (1.1.1) relação de trabalho (como empregado, diretor ou similar) ou societária; e (1.1.2) relação de prestação de serviços (entre eles, jurídicos). A categoria (1.2) não justifica um terceiro nível de clivagem. 
A categoria (2), que envolve tanto relações negociais quanto familiares, pessoais ou sociais (com as quais a primeira geralmente se sobrepõe), também admitiria, idealmente, um segundo nível de clivagem, do qual derivariam quatro ramos: (2.1) relação do árbitro com o advogado que representa a parte; (2.2) relação do árbitro com o escritório de advocacia do advogado que representa a parte; (2.3) relação do escritório ao qual pertence o árbitro com o advogado; (2.4) relação do escritório ao qual pertence o árbitro com o escritório ao qual pertence o advogado que representa a parte. No entanto, os casos práticos consultados frequentemente se sobrepõem a essas subcategorias, razão pela qual pareceu mais adequado tratá-las todas em conjunto, considerando-se as distinções e particularidades à medida que elas se fizerem necessárias.

A categoria (3), por não se sustentar primordialmente na existência de qualquer outra relação que envolva o árbitro com as partes, seus advogados ou pessoas e entidades a elas ligadas, congrega hipóteses bastante heterogêneas, a saber: (3.1) contato anterior do árbitro com a causa, com causas derivadas ou com questões similares; (3.2) posições técnicas defendidas pelo árbitro em estudos acadêmicos ou similares; (3.3) duplo papel do árbitro, que também funciona como advogado em outros processos; (3.4) atuação do árbitro no procedimento; (3.5) nomeação repetitiva do árbitro; (3.6) particularidades culturais ou distorções cognitivas derivadas da história de vida do árbitro; e (3.7) nacionalidade do árbitro.

A categorização das situações ou eventos mais comum habilita o intérprete a se utilizar dos respectivos critérios de análise, facilitando a sua conclusão a respeito da aparência da imparcialidade do árbitro. Por exemplo, a existência de uma relação negocial na qual o árbitro é diretor da parte, enseja a utilização, entre outros, de critérios de análise econômicos (ou seja, a repercussão econômica que a decisão na arbitragem irá propiciar para a parte ou para o próprio árbitro, devido à condição funcional que ostenta em relação à parte) para a demonstração da aparência de imparcialidade, ao passo que a existência de uma relação pessoal entre árbitro e parte descarta, de início, a utilização de critérios econômicos, tornando importante a demonstração da profundidade, duração e importância dessa relação.

A categorização, como recorte ideal e valorativo de eventos e situações do mundo fático, não obsta a sobreposição ou interpolação de categorias. De fato, em que categoria se 
inscreveria a situação em que um familiar do árbitro é sócio ou diretor da empresa parte da arbitragem? Seria pessoal, visto que haveria uma relação familiar envolvida (o que denotaria a aparência de imparcialidade quanto mais estreita fosse a relação), ou seria negocial, tendo em vista a possibilidade de repercussão econômica (o que denotaria a aparência de imparcialidade quanto menor o benefício econômico envolvido)? De modo análogo, em que categoria se inscreveria a situação em que o árbitro, além de ter trabalhado em conjunto com o advogado da parte, é também seu amigo? Essas e outras questões serão tratadas a seguir, a partir do exame dos casos que possibilitam tanto a eleição das categorias apresentadas no presente estudo quanto dos respectivos critérios de análise.

Mantendo-se fiel ao método utilizado na eleição das categorias, o presente estudo tratará primeiramente dos casos que ensejaram a referida eleição, para, ao final, expor e comentar os critérios de análise mais relevantes.

\subsubsection{Categoria (1.1.1) - Relação de trabalho ou societária do árbitro ou de pessoas próximas com a parte ou entidades a ele envolvidas}

A categorização sugerida no presente estudo identifica como primeiro tipo de situação ou evento comum, hábil a ensejar a aparência de parcialidade do árbitro, a existência de relação de trabalho ou societária deste com a parte ou entidades a ela envolvidas. São os casos em que o árbitro figura como funcionário ou diretor da empresa que é parte na arbitragem ou pertencente ao grupo econômico da empresa que é parte na arbitragem. Também se enquadram na categoria os casos em que o árbitro detém ações ou quotas da sociedade parte na arbitragem ou de sociedade a ela coligada.

Diferentemente do que apontaria o senso comum, é possível que casos enquadrados na categoria em questão não suscite a aparência de parcialidade, que depende de alguns critérios de análise. Foi o que ocorreu no caso Vivendi v. Argentina, processado segundo as regras ICSID, e que envolveu a conhecida profissional da arbitragem internacional, Gabrielle Kaufmann-Kohler. A árbitra havia sido eleita, em 2006, para a função de presidente do Comitê de Nomeação e Governança, participando assim da Diretoria do 
Grupo UBS, banco de investimentos que possuía considerável fração do capital de duas empresas - Vivendi (com 2,38\% do capital votante) e Suez (com 2,1\% do capital votante) - envolvidas em processos arbitrais dos quais Kaufmann-Kohler já compunha o tribunal arbitral. Parte da remuneração de Kaufmann-Kohler era, inclusive, recebida em ações do UBS.

A Argentina, uma das partes nesse processo, afirmou ter tomado conhecimento da posição de Kaufmann-Kohler apenas em 2007, após ter sido proferida a segunda decisão no caso Vivendi, apresentando impugnação na qual alegou que a árbitra não poderia exercer um julgamento independente por conta da sua posição na diretoria. Vivendi alegou que Kaufmann-Kohler seria completamente independente, sem qualquer envolvimento material ou interesse no desenvolvimento financeiro do UBS, e que Kaufmann-Kohler não tinha o dever de informar a assunção do cargo porque o fato era público e irrelevante para sua independência ou imparcialidade.

Conforme as regras ICSID, os dois outros árbitros do tribunal deliberaram sobre a impugnação, entendendo que Kaufmann-Kohler permanecia apta a julgar as causas, que seu envolvimento com Vivendi e Suez seria (se muito) tênue e que o benefício que poderia derivar de uma decisão favorável seria insubstancial e imaterial. Os árbitros utilizaram quatro critérios para avaliar a conexão entre a árbitra e a parte: proximidade, intensidade, dependência e materialidade ${ }^{360}$. A proximidade seria remota e indireta, sendo que a árbitra jamais havia tido contato com a diretoria das empresas e não sabia quem eram os seus acionistas. A intensidade estaria afastada diante da inexistência de qualquer contato da árbitra por conta do seu cargo de diretora do UBS. Inexistiria dependência da árbitra, notadamente à vista de que ela não auferiria qualquer benefício ou vantagem relativamente ao ganho de causa por qualquer das partes. Por fim, a participação do UBS nas empresas não seria material para o desempenho financeiro, lucratividade ou para a valorização das ações do UBS, e de forma alguma afetaria a remuneração da árbitra na qualidade de diretora.

\footnotetext{
${ }^{360}$ Decision on a Second Proposal for the Disqualification of a Member of the Arbitral Tribunal, proferida para os casos ICSID Case $n^{\circ}$ ARB/03/19 (Vivendi) e ICSID Case $n^{\circ}$ ARB/03/17 (Suez), disponível no endereço eletrônico http://italaw.com/documents/Suez-VivendiChallenge2.pdf; consulta em 21.02.2014.
} 
Interessante caso - em que a evidente parcialidade não foi considerada em função do conhecimento prévio, pelas partes, dos efeitos da cláusula compromissória, que não poderia ser contestada sob pena de desestabilizar o contrato no qual estava inserida, em atentado às regras de direito comercial - foi decidido por corte estatal norte-americana. Trata-se do caso Westinghouse Electric v. NYC Transit Authority ${ }^{361}$, no qual a cláusula compromissória constante do contrato proposto em licitação vencida pela Westinghouse dispunha que os litígios que envolvessem as partes seriam resolvidos pelo Chief Electrical Officer da própria autoridade de trânsito, em decisão que seria sujeita a controle judicial (“judicial review”) apenas se fosse arbitrária ou gritantemente errônea por evidente má-fé. Depois de anos de difícil relacionamento contratual, a Westinghouse notificou a autoridade de trânsito - na pessoa do Chief Electrical Officer - alegando que as restrições impostas pela autoridade de trânsito configuravam uma efetiva ordem de interrupção das atividades ("stop work order"), o que justificaria a interrupção da execução do contrato como um todo. O Chief Electrical Officer respondeu que essa atitude configuraria inadimplemento contratual, o que levou a Westinghouse a iniciar a arbitragem que, como seria de se esperar, foi decidida desfavoravelmente à Westinghouse pelo próprio Chief Electrical Officer. Trazida a questão ao Judiciário, a Corte de Apelação de Nova Iorque apontou que a cláusula de solução de controvérsias havia sido livre e conscientemente aceita pelas partes, que refletia uma negociação multimilionária da qual as partes aceitaram os termos, especificações e riscos, sendo que negar os efeitos dela seria desequilibrar economicamente o contrato e a própria concorrência pública ${ }^{362}$.

Situações em que pessoas próximas ao árbitro - isto é, seus familiares - sejam empregados ou diretores das partes na arbitragem também podem ser enquadradas na categoria proposta. Dois foram os casos identificados. No primeiro, o caso Morelite v. NYC District Council, o pai do árbitro era o presidente do sindicato parte no litígio. O árbitro não revelou a relação de parentesco. Como nenhuma das partes provou qual o grau de ligação negocial, econômica ou sentimental entre pai e filho, a Corte de Apelação do Segundo Circuito utilizou-se de presunção para anular a sentença arbitral, sob o entendimento de

\footnotetext{
${ }^{361}$ Caso Westinghouse Electric Corporation v. New York City Transit Authority et al., 623 N.E. 2d 531 (N.Y. 1993). Decisão disponível no endereço eletrônico http://www.leagle.com/decision/199312982NY2d47_1125; consulta em 21.02.2014.

${ }^{362}$ Comentário à decisão, sob a ótica da renúncia ou preclusão da faculdade de impugnação do árbitro, é feita no capítulo 4.4 do presente estudo.
} 
que, em geral, filhos são leais a seus pais e inclinados a beneficiá-los ${ }^{363}$. Em outro caso, no qual o irmão do árbitro era funcionário do sindicato parte da arbitragem (relação também não revelada pelo árbitro), a conclusão foi em sentido contrário. Foi feita uma análise profunda da relação entre os irmãos (no passado, árbitro e seu irmão haviam morado juntos e haviam sido proprietários de uma lavanderia). Uma vez analisado o eventual benefício econômico do árbitro e do seu irmão com o resultado da arbitragem, chegou-se à conclusão que nem o árbitro, nem seu irmão teriam qualquer interesse discernível no resultado do julgamento. Ademais, foi constatado que o árbitro havia julgado contra o sindicato em que o irmão trabalhava mais da metade das vezes em que havia exercido a função. Assim, a Corte de Apelação do Quarto Circuito não encontrou interesse econômico direto do árbitro ou mesmo do seu irmão no resultado da arbitragem, razão pela qual declarou válida a sentença arbitral, reformando a decisão da instância inferior ${ }^{364}$. Interessante notar que, na decisão, a Corte de Apelação referendou os critérios de análise relativos à demonstração da parcialidade, segundo o seguinte elenco: $(i)$ existência de interesse pessoal, pecuniário ou similar do árbitro no resultado da arbitragem; (ii) imediatidade ("directness") da relação entre árbitro e parte; (iii) conexão da relação com a arbitragem; e (iv) proximidade de tempo entre a relação e o procedimento arbitral.

Caso já houve em que a relação não se estabeleceu entre árbitro e parte, mas entre o primeiro e um concorrente da parte no mercado. Trata-se do já referido caso $A T \& T^{365}$, no qual o árbitro, Yves Frontier, não revelou ser diretor não-executivo da empresa Nortel e deter 474 ações representativas do seu capital. A House of Lords afastou o pedido de anulação da sentença arbitral, entre outras razões, pelo não exercício efetivo da diretoria e pela pequena quantidade de ações detidas pelo árbitro.

\footnotetext{
${ }^{363}$ No original: "We know nothing more about the relationship between Patrick Campbell, Jr. and Patrick Campbell, Sr. except that the former is the latter's son. We do not know how close they are, or how independent the son is of the father, or how divergent their views on the issues giving rise to the arbitrated dispute. And without knowing more, we are bound by our strong feeling that sons are more often than not loyal to their fathers, partial to their fathers, and biased on behalf of their fathers. We cannot in good conscience allow the entering of an award grounded in what we perceive to be such unfairness." Caso Morelite Constr. Corp. v. New York City Dist. Council Carpenters Ben. Funds, 748 F.2d 79, (2d Cir.1984). Decisão disponível no endereço eletrônico https://law.resource.org/pub/us/case/reporter/F2/748/748.F2d.79.84-7351.86.html; consulta em 21.02.2014.

${ }^{364}$ Caso Consolidation Coal Company v. Local 1643, United Mine Workers of America, 48 F.3d 125 ( $4^{\text {th }}$ Cir. 1995); Decisão disponível no endereço eletrônico http://law.justia.com/cases/federal/appellatecourts/F3/48/125/607195/, consulta em 21.02.2014.

${ }^{365}$ Vide notas de rodapé $n^{\text {os }} 140$ e 141.
} 
A Corte da CCI já enfrentou casos enquadráveis na categoria proposta no presente estudo, não confirmando a nomeação de árbitro que revelou ser diretor de empresa que tinha participação indireta em uma das partes do processo $\operatorname{arbitral}^{366}$, nem de árbitro que revelou ter trabalhado no departamento jurídico de uma subsidiária de uma das partes por seis anos e no departamento jurídico de uma subsidiária indireta da mesma parte nos quatro anos seguintes, em relação que havia terminado um ano antes da apresentação da declaração de independência ${ }^{367}$. Também não foi confirmada a nomeação de árbitro indicado por um governo, que revelou ser Advogado-Geral do Ministério da Justiça ${ }^{368}$.

Referindo-se às situações práticas, as IBA Guidelines tratam do tema na Lista Vermelha de Eventos Irrenunciáveis, coibindo que o árbitro seja $(i)$ representante legal de pessoa jurídica parte no procedimento arbitral ${ }^{369}$; ou (ii) administrador, conselheiro, membro de órgão supervisor ou possua influência de controle semelhante sobre uma das partes ${ }^{370}$. A Lista Vermelha de Eventos Renunciáveis prevê situação em que o árbitro seja (iii) detentor, direta ou indiretamente, de participações societárias em uma das partes ou em coligada de uma das partes, se pessoa jurídica de direito privado ${ }^{371}$. A Lista Laranja trata de situações em que o árbitro (iv) tenha se associado, nos três anos anteriores, a uma parte ou à coligada de uma das partes sob um vínculo profissional, como o de antigo empregado ou sócio ${ }^{372} ;(v)$ detenha, direta ou indiretamente, participações societárias em uma das partes ou em coligada, se de capital aberto, e que sejam significativas em virtude de seu volume ou natureza ${ }^{373}$; e (vi) seja administrador, conselheiro ou membro de órgão supervisor, ou possua influência de controle semelhante em coligada de uma das partes, embora não esteja diretamente envolvida no objeto da controvérsia ${ }^{374}$. A Lista Verde

\footnotetext{
366 ANNE MARIE WhITESELL. Independence in ICC arbitration: ICC Court practice concerning the appointment, confirmation, challenge and replacement of arbitrators, in International Court of Arbitration Bulletin: 2007 Special Supplement - Independence of Arbitrators. Paris: ICC Publishing, 2008, p. 20.

${ }^{367}$ ANNE MARIE WhiteSELL. Independence ... op. cit., p. 21.

${ }^{368}$ ANNE MARIE WHITESELL. Independence... op. cit., p. 24.

${ }^{369}$ Seção 1.1.

${ }^{370}$ Seção 1.2.

${ }^{371}$ Seção 2.2.1.

${ }^{372}$ Seção 3.4.2.

${ }^{373}$ Seção 3.5.1.

${ }^{374}$ Seção 3.5.4.
} 
considera a hipótese de o árbitro possuir volume insignificante de participação societária em uma das partes ou coligadas, se empresas de capital aberto ${ }^{375}$.

A conjunção das características consideradas nas decisões mostra que os critérios de análise relevantes giram em torno de dois pontos: (1) a relação negocial em si mesma; e (2) a existência e substancialidade da repercussão econômica da decisão para o árbitro.

$\mathrm{Na}$ análise da relação em si mesma, são ponderadas as particularidades de cada caso à luz do que comumente acontece, aferindo-se a proporcionalidade da identificação do evento ou situação com a aparência de parcialidade e das respectivas consequências jurídicas de acordo com os seguintes critérios:

- proximidade da relação, sendo que quanto mais próxima e direta ela for, ou seja, quanto menos pessoas ou entidades se interpuserem entre parte e árbitro, mais aparente a parcialidade. De fato, mais aparente a parcialidade se o árbitro for sócio com fração considerável do capital social, diretor ou empregado da parte, do que se ele for titular de algumas quotas ou ações da empresa, ou as detenha via fundo de investimentos;

- intensidade da relação, sendo que quanto mais intensa ela for, mais aparente a parcialidade. De fato, mais aparente a parcialidade se o árbitro for diretor que participa das decisões da parte, exercendo com habitualidade essa função, do que se ele possuir um cargo meramente consultivo em uma subsidiária; e

- contemporaneidade da relação, sendo que quanto mais próxima no tempo for o processo arbitral, mais aparente a parcialidade. De fato, mais aparente a parcialidade se o árbitro continuar sendo funcionário da parte, do que se ele tiver exercido tal cargo no passado distante.

A análise da existência e substancialidade da repercussão econômica da decisão para o árbitro é feita de acordo com os seguintes temas:

375 Seção 4.5.2. 
- existência demonstrável de benefício econômico para o árbitro ou pessoa a ele ligada, tais como a valorização de ações representativas do capital social ou recebimento direto de dinheiro;

- imediatidade ("directness") do benefício, sendo que quanto mais imediato o benefício, mais aparente a parcialidade. A imediatidade se revela pelo número de passos que constituem a cadeia de eventos pela qual o impacto da decisão irá repercutir até efetivamente afetar o interesse econômico do julgador $^{376}$. De fato, mais aparente a parcialidade do árbitro se ele atribui valores diretamente à parte com a qual tem relação do que se participar de arbitragem na qual for parte uma concorrente dessa empresa no mercado, condenando-a;

- substancialidade, sendo que quanto mais substancial o benefício, mais aparente a parcialidade. A substancialidade incorpora um componente absoluto, que representa o real ou verdadeiro ("actual") valor financeiro do impacto da decisão; e um componente relativo, que estabelece uma proporção entre o valor absoluto do impacto e o status econômico do julgador $^{377}$. De fato, mais aparente a parcialidade do árbitro se o benefício econômico for multimilionário e o árbitro não possuir extenso patrimônio e outras fontes de renda do que se o benefício for mínimo frente ao patrimônio ostentado pelo árbitro, com mais amplas fontes de renda.

As decisões analisadas demonstram que nenhum dos critérios pode, isoladamente, confirmar que a norma criada pelo intérprete respeita a coerência e coesão do ordenamento aplicável. Cada caso, nas suas particularidades, ensejará o destaque de critérios diferentes, levando a conclusões também diferentes. No entanto, é possível perceber a constante exigência de repercussão econômica da decisão para o árbitro (ou pessoa próxima a ele), sem o que resta muito dificultada a demonstração da aparência de parcialidade.

\footnotetext{
${ }^{376}$ JOHN R. AlLiSON. A process value analysis of decision-maker bias: the case of economic conflict of interest, in American business law journal, v. 32, n. 4, 1995, pp. 514-515.

${ }^{377}$ JOHN R. AlLison. A process... op. cit., p. 515.
} 


\subsubsection{Categoria (1.1.2) - Relação de prestação de serviços do árbitro ou de seu escritório com a parte ou pessoas e entidades com ela envolvidas}

A segunda categoria sugerida pelo presente estudo trata da situação ou evento em que o árbitro ou sociedade à qual ele pertença preste serviços à sociedade parte na arbitragem ou à sua coligada.

O caso mais representativo dessa categoria é o conhecido Commonwealth Coatings ${ }^{378}$, no qual a Suprema Corte norte-americana reconheceu a parcialidade do árbitro que havia prestado diretamente serviço a uma das partes - relativamente a projeto que acabou sendo objeto de controvérsia -, recebendo dela remuneração de USD 12 mil, sem que nada tivesse revelado no curso do procedimento arbitral. Ponderando que a relação entre árbitro e parte não era de minimis, além de ser direta, a Suprema Corte entendeu evidente a parcialidade do árbitro, consoante o FAA.

Às vezes, não apenas as relações já estabelecidas entre árbitro e parte, mas também aquelas a serem formalizadas no futuro podem ensejar a aparência de imparcialidade. Como já ressaltado no caso KPMG v. ProfilGruppen ${ }^{379}$, a relação negocial da parte com o árbitro (ou seu escritório) foi formalmente iniciada após o encerramento do processo arbitral, não obstante as negociações para tanto tenham ocorrido antes desse encerramento. Tal fato levou ao reconhecimento da violação da imparcialidade do árbitro.

A substancialidade da relação entre árbitro e parte para a configuração da parcialidade é ressaltada no caso Amco v. Indonesia, processado segundo as regras ICSID, no qual a Indonésia impugnou o árbitro indicado pela sua adversária por ele (coárbitro) ter respondido à consulta tributária do acionista controlador da Amco três meses antes do início da arbitragem. A Amco revelou que a consulta tributária feita ao árbitro rendeu menos que USD 450 e foi concedida à pessoa física, em duas páginas. Os dois árbitros

\footnotetext{
${ }^{378}$ Mais detalhes sobre o caso nas pp. 47-48 do presente estudo.

${ }^{379}$ Mais detalhes sobre o caso nas pp. 34-35 do presente estudo.
} 
incumbidos de decidir a impugnação rejeitaram-na, apontando que uma consulta legal sobre uma questão não se compara a uma relação advogado-cliente regular ${ }^{380}$.

No mesmo sentido foi a decisão proferida pelo comitê nomeado pelo presidente do Conselho Administrativo do ICSID para decidir o pedido de anulação da sentença arbitral proferida no caso Vivendi Universal v. Argentina ${ }^{381}$. A Argentina impugnou o próprio presidente do comitê, o profissional canadense Yves Fortier, sob a alegação de que um dos seus sócios no escritório Ogilvy Renault havia orientado a empresa predecessora da Vivendi (Compagnie Generale des Eaux) em uma questão tributária de Quebec, o que rendeu ao escritório um total de USD 216 mil em honorários, dos quais USD 204 mil se referiam a trabalho prestado entre 1995 e 1999. O trabalho, vindo sob solicitação de outro escritório de advocacia (que atuava como "leading counsel"), ainda não estava terminado ao tempo em que se desenvolvia o procedimento de anulação da sentença, restando ainda tarefas triviais relativas ao "winding $u p "$ da operação, que resultariam em honorários de não mais que USD 2 mil. Fortier não havia se envolvido pessoalmente no trabalho, que nada tinha a ver com o litígio submetido à arbitragem. O comitê asseverou que as relações profissionais do árbitro com uma parte não configuravam base automática para o seu afastamento, e que todas as circunstâncias precisavam ser consideradas para determinar se a relação era significativa ou suficiente para justificar dúvidas razoáveis sobre a capacidade de o julgador decidir livre e independentemente. Necessário, segundo o comitê, existir um risco real de falta de imparcialidade baseado em fatos, e não apenas mera especulação ou inferência. O pedido de anulação foi denegado, pois (i) Fortier havia, imediata e completamente, revelado a relação e fornecido mais informações quando requeridas, mantendo total transparência; (ii) Fortier não possuía relação advogado-cliente direta com os requerentes ou suas afiliadas; (iii) o trabalho prestado pelos colegas de Fortier não tinham relação com o conflito submetido à arbitragem; (iv) o trabalho prestado não consistia na prestação de orientações jurídicas ou estratégicas aos requerentes, mas sim concernentes a um negócio específico, no qual a Ogilvy Renault não era a “leading firm”; e

\footnotetext{
${ }^{380}$ Assim: "A legal advice on a minor question which could not have been anything but minor, as the fees received show it, is of no [bearing] on the 'reliability' of the advisor to be an arbitrator appointed by the client to whom he had given this advice. To give and to receive such an advice does not create an 'attorneyclient' relationship and is by no means comparable to the situation of a regular counsel of the appointing party". Caso referido por KAREL DAELE. Challenge... op. cit., pp. 271-272.

${ }^{381}$ Caso Compañía de Aguas del Aconquija S.A. \& Vivendi Universal v. Argentine Republic, ICSID Case No. ARB/97/3. Decision on the challenge to the President of the Committee; disponível no endereço eletrônico http://www.italaw.com/sites/default/files/case-documents/ita0208.pdf; consulta em 21.02.2014.
} 
(v) a relação legal entre a Ogilvy e a parte logo se encerraria com o fechamento do negócio.

Um terceiro caso ICSID é o Lemire v. Ukraine, no qual o árbitro indicado pelo investidor revelou, pouco mais de um ano após a constituição do tribunal, que seu escritório havia iniciado o patrocínio da Ucrânia em outro procedimento arbitral perante a ICJ, no qual não se envolveria, afirmando que o fato não afetaria sua imparcialidade, mas que renunciaria ao encargo se qualquer das partes assim requeresse. O investidor afirmou não ter objeções ao árbitro. A Ucrânia informou que não teria objeções sob duas condições: o escritório teria que levantar um "ethical screen" para isolar o árbitro do procedimento ICJ, e o investidor e seu advogado teriam que se comprometer a não invocar o envolvimento do escritório do árbitro no caso ICJ para impugnar, em estágio posterior, a sentença a ser proferida. O "ethical screen" foi estabelecido a contento de ambas as partes, mas elas não se compuseram sobre os termos do compromisso a ser prestado pelo investidor e seu advogado (sendo que este último havia apresentado declaração em seu nome e em nome do seu cliente, defendendo, pelos seus poderes de representante, também se manifestava em nome de Lemire, o que a Ucrânia não aceitou), razão pela qual a própria Ucrânia - e não Lemire - impugnou o árbitro, primeiramente sob a alegação de não cumprimento da condição que havia estabelecido, e depois sob a alegação de que a posição do árbitro ensejaria conflito, visto que o Ministro da Justiça da Ucrânia iria gerir tanto o caso ICSID como o ICJ. A impugnação foi afastada pelos coárbitros, que consideraram que o "ethical screen" seria suficiente para a manutenção da condição de imparcialidade do árbitro ${ }^{382}$.

Outro caso representativo é o $H S M V v$. ADI, tratado segundo o FAA. A sociedade HSMV era baseada na Califórnia e a sociedade ADI era integralmente detida Commonwealth of Australia. No debate para a elaboração da convenção de arbitragem, em novembro de 1998, o advogado da HSMV enviou ao advogado da ADI lista com proposta de dois nomes para o painel arbitral, Geoffrey Gibson e Michael Pryles, acompanhados dos respectivos currículos. Nem a ADI, nem seu advogado propuseram outro nome ou investigaram os árbitros propostos, pois, nas palavras do advogado da ADI, não havia razão para duvidar das suas credenciais, visto que ambos os nomes eram sócios dos maiores escritórios de advocacia da Austrália. Em paralelo, em vista do interesse da Commonwealth of Australia

${ }^{382}$ Caso Joseph Charles Lemire v. Ukraine, ICSID Case No. ARB(AF)/98/1, referido por KAREL DAELE. Challenge... op. cit., pp. 112-114 e 329-330. 
em privatizar a ADI e a necessidade de revelar aos interessados as relações com a HSMV, a agência da ADI enviou ao presidente da HSMV, em outubro de 1998, uma proposta de acordo de confidencialidade em cuja carta de envio constava "[s] hould you have any queries, please call me on 6126208 9114. Mr. Bill Conley of Blake Dawson Waldron (61 26234 4017) can assist in respect of the confidentiality arrangements", tendo o presidente da HSMV dado o encaminhamento do documento ao seu pessoal para as providências. Em junho de 1997 (após a conclusão da arbitragem), o assessor financeiro da Commonwealth of Australia, contatou a HSMV para informar que muniria interessados na compra da ADI com os contratos entre a empresa e a HSMV. A HSMV respondeu, requerendo os acordos de confidencialidade entre ADI e os potenciais compradores (resposta enviada pelo escritório Blake Dawson Waldron). Foi nesse momento, segundo a alegação da HSMV, que ela se apercebeu que o escritório que estava operando a venda da ADI era o mesmo ao qual pertencia o árbitro Gibson. Este explicou que não tinha conhecimento do envolvimento do seu escritório na venda da ADI. No entanto, na ação anulatória da sentença, a Corte Distrital da Califórnia considerou que envolvimento contemporâneo da banca na alienação da sociedade parte na arbitragem claramente representava conflito de interesses e que Gibson tinha o dever de investigar as relações do seu escritório ${ }^{383}$. A Corte também afastou a alegação de que a HSMV teria renunciado à faculdade de impugnar o árbitro, pois uma mera frase que fazia referência ao escritório de advocacia em uma de muitas comunicações entre as partes não poderia configurar ciência da HSMV quanto à representação dos interesses da detentora da $\mathrm{ADI}$, não tendo sido demonstrado que a primeira empresa efetivamente sabia, compreendia ou tinha conhecimento da presença de um conflito de interesses antes da conclusão da arbitragem.

A relação entre árbitro e parte deve ser relativamente próxima e regular para ensejar a aparência de parcialidade. É o que demonstra a decisão proferida na ação anulatória da sentença arbitral do caso Reeves Brothers v. Capital-Mercury, no qual os árbitros (pertencentes ao mercado têxtil) foram escolhidos pela instituição arbitral GAC, uma divisão da AAA, consoante o seu regulamento: Norman Hackel, como presidente, e Norman Katz e Lawrence H. Bober como coárbitros. Em revelação feita várias semanas após a sua indicação, o coárbitro Bober informou que havia sido empregado de uma instituição bancária da qual Reeves era cliente. Capital impugnou a indicação do árbitro,

${ }^{383}$ Caso HSMV Corp. v. ADI Ltd., 72 F.Supp.2d 1122 (C.D. Cal. 1999). Decisão disponível no endereço eletrônico http://www.leagle.com/decision/1999119472FSupp2d1122_11086; consulta em 21.02.2014. 
impugnação à qual a AAA não deu provimento. Uma das testemunhas prospectivas arroladas pela Reeves foi David Borowoka, que foi seu funcionário desde 1986, chegando a presidente quando se desligou, em 1995, permanecendo apenas como consultor. Quando o coárbitro Hackel viu a testemunha Borowka na sala de audiência, informou que ele foi um antigo e próximo parceiro de negócios. A Capital requereu a remoção de Hackel e um membro da AAA, após falar com o coárbitro, negou o pedido da Capital. Borowka não prestou testemunho. Posteriormente à arbitragem, Reeves esclareceu que o coárbitro Bober não conhecia a empresa ou sua conta enquanto era funcionário da instituição bancária (entre 1951 e 1987), e que a relação entre a testemunha Borowka e o coárbitro Hackel perdurou nos anos 1950, quando este trabalhava para a United Merchants and Manufactures, a qual deixou em 1981. A ação anulatória da sentença arbitral, que trazia como causa de pedir a violação da Rule 15 do regulamento do GAC $^{384}$, foi julgada improcedente tendo em vista que as relações apontadas pela Capital haviam sido reveladas antes de ter sido proferida a sentença e afastadas como causa de parcialidade de acordo com o regulamento adotado pelas partes. Além disso, com apoio em outros julgados, a Corte Distrital de Nova Iorque declarou que a "evident partiality" - imposta pela Section 10 do FAA para a anulação das sentenças arbitrais - deveria ser encontrada quando uma pessoa razoável pudesse concluir a imparcialidade do árbitro, e que o fato de um árbitro simplesmente julgar em favor da parte contrária não satisfazia o requisito de demonstração da parcialidade $\mathrm{e}^{385}$.

Algumas vezes, portanto, não é o árbitro quem estabelece contato direto com a parte, mas sim o seu escritório. Nesses casos, deve ser considerada a ciência ou não do árbitro a respeito da existência dessa relação, bem como se a falta de ciência foi devida à desídia do árbitro no seu dever de se informar ou então à dificuldade mesma de obter essa informação

\footnotetext{
${ }^{384}$ A Rule 15 assim dispunha: "Any person appointed as neutral arbitrator shall disclose to the Secretary any circumstance likely to affect impartiality, including any bias or any financial or personal interest in the result of the arbitration or any past or present relationship with the parties or their representatives. The Secretary shall also request, and each party and their representatives shall disclose to the Secretary, any such circumstances known to them. Upon receipt of such information from the arbitrator or another source, the Secretary shall communicate the information to the parties and, if deemed appropriate, to the arbitrator and others. Upon objection of a party to the continued service of a neutral arbitrator, the Secretary shall determine whether the arbitrator should be disqualified and shall inform the parties of the decision, which shall be conclusive."

${ }^{385}$ Caso Reeves Bros., Inc. v. Capital-Mercury Shirt Corp., 962 F. Supp. 408 (S.D.N.Y. 1997). Decisão disponível no endereço eletrônico https://www.courtlistener.com/nysd/cR7G/reeves-bros-inc-v-capitalmercury-shirt-corp/; consulta em 21.02.2014.
} 
- dificuldade que se agrava quanto maior for o escritório e mais profissionais e filiais ele possuir.

Por reconhecer o dever do árbitro em obter informações que possam levantar dúvidas quanto à sua imparcialidade (um dos feixes do dever de revelação), é importante a decisão da Corte de Apelação do Nono Circuito no caso Schmitz v. Zilveti. No caso, a sentença arbitral foi proferida em processo desenvolvido no NASD, cujo Código de Procedimento (equivalente a um regulamento de arbitragem), em sua Section 23(b), estabelecia que: "[p]ersons who are requested to accept appointment as arbitrators should make a reasonable effort to inform themselves of any interests or relationships described in Paragraph (a) above" ${ }^{386}$. Após a sentença arbitral, a parte vencida (Jean e Leonard Schmitz) fez uma pesquisa na qual descobriu que o escritório de advocacia de um dos árbitros (John R. Conrad) havia representando uma empresa controladora de uma das partes (Prudential Insurance Co., controladora da parte Pru-Bache) em pelo menos dezenove casos nos últimos trinta e cinco anos, tendo a representação mais recente terminado vinte e um meses antes do início do processo arbitral. $\mathrm{O}$ árbitro nada havia revelado a esse respeito, visto que não tinha conhecimento da representação. Em ação anulatória da sentença arbitral, a Corte de Apelação do Nono Circuito ${ }^{387}$ entendeu que o árbitro tinha o dever de investigar as representações do seu escritório, não apenas porque isso era requerido pelas regras do processo arbitral, mas também porque "[r]equiring arbitrators to make investigations in certain circumstances gives arbitrators an incentive to be forthright with the parties, honestly disclosing what arbitrators might otherwise have an incentive to hide".

Os critérios da temporalidade da relação entre parte e escritório do árbitro e da ciência deste a respeito dessa relação foram tratados no caso Al-Harbi v. Citibank, segundo o FAA. Contra sentença proferida em arbitragem da qual foram partes Abdullah E. Al-Harbi e uma subsidiária integral do Citibank, o primeiro apresentou demanda anulatória, sob a alegação de que o árbitro escolhido em comum por ambas as partes, Kenneth R. Feinberg,

\footnotetext{
${ }^{386}$ Essas relações descritas no parágrafo (a) incluíam "[a]ny direct or indirect financial or personal interest in the outcome"; "any (...) financial, business, professional, family, or social relationships that are likely to affect impartiality or might reasonably create an appearance of partiality or bias" e "any personal relationships with any party, its counsel, or witnesses."

${ }^{387}$ Caso Jean Schmitz; Leonard Schmitz v. Carlos J. Zilveti, III; Nicholas S. Meris; Prudential-Bache Securities Inc., $20 \quad$ F.3d $1043 \quad\left(9^{\text {th }}\right.$ Cir. 1994). Decisão disponível no endereço eletrônico http://www.leagle.com/decision/1994106320F3d1043_1893; consulta em 21.02.2014.
} 
havia anteriormente trabalhado (e da qual já tinha se desligado quando do processo arbitral) em uma banca de advogados que havia representado o Citibank em casos não relacionados ao processo arbitral ${ }^{388}$. Restou demonstrado que o árbitro não tinha conhecimento dos serviços, e que não teria o dever de investigar a existência de fatos marginais, notadamente quando se ligavam à lista de clientes de seu antigo escritório.

Outra decisão que envolve o critério temporalidade foi emanada pela Corte da CCI, que afastou impugnação contra o árbitro nomeado pelos requeridos com base na revelação feita pelo julgador, segundo a qual seu escritório havia patrocinado demanda contra uma subsidiária dos requerentes, ao longo de dois anos, em caso encerrado aproximadamente cinco anos antes do início da arbitragem, no qual o árbitro não tinha trabalhado e do qual anteriormente nada sabia ${ }^{389}$.

O caso Gianelli Money v. ADM Investor ${ }^{390}$ insere a questão do conhecimento do árbitro quanto às relações do passado entre o escritório ao qual posteriormente se incorporou, com o presidente de uma empresa ligada diretamente ao conflito. No caso, o árbitro não conhecia tais vínculos, sendo que a única relação posterior à sua integração na banca, apontada no curso da arbitragem, não ensejou impugnação das partes. No caso Lifecare International v. CD Medical ${ }^{391}$, não foi considerado parcial o árbitro que, meses antes de ser indicado, tornou-se of counsel do escritório que, mais de quatro anos antes do início do processo arbitral, havia sido contratado pelas partes para revisar um aditamento contratual celebrado entre elas, e que, dois anos antes do início do processo arbitral, havia sido (o escritório, não o árbitro) consultado por uma delas para representá-la na arbitragem. Foi demonstrado que o árbitro não conhecia essas situações, ocorridas anos antes de tornar-se of counsel.

Em caso análogo, relativo a arbitragem AAA, o árbitro não foi considerado parcial em razão de a banca, da qual havia se desligado seis meses antes do início do processo arbitral,

\footnotetext{
${ }^{388}$ Caso Abdullah E. Al-Harbi v Citibank N.A and Citibank A.S., 85 F. 3d 680 (U.S. App. D.C. 115). Decisão disponível no endereço eletrônico https://law.resource.org/pub/us/case/reporter/F3/085/85.F3d.680.957192.html; consulta em 21.02.2014. Casos similares na LCIA e na CCI são referidos por KAREL DAELE. Challenge... op. cit., pp. 272-274.

389 ANNE MARIE WHITESELL. Independence... op. cit., pp. 30-31.

${ }^{390}$ Para mais detalhes, vide nota de rodapé n ${ }^{\circ} 159$.

${ }^{391}$ Para mais detalhes, vide nota de rodapé nº 161.
} 
ter prestado serviços (concluídos mais de seis anos antes do início do processo arbitral) a empresas ligadas a uma das partes. O árbitro sequer tinha conhecimento desses serviços ${ }^{392}$.

Houve caso na CCI em que o árbitro não foi confirmado por ter revelado que, em três ocasiões, seu escritório de advocacia havia ajuizado demanda contra uma das partes ${ }^{393}$. Houve, também, caso em que o árbitro presidente foi impugnado com sucesso por não ter revelado que filial estrangeira do seu escritório de advocacia havia representado um cliente em ação contra coligada de uma das partes, em matéria não relacionada com a arbitragem $^{394}$.

Os problemas com a imparcialidade do árbitro são agravados quando este pertence a grandes bancas jurídicas: trata-se de caso CCI em que o coárbitro indicado por uma das partes revelou que diversos sócios do seu escritório, situados nas filiais localizadas em outros países, representavam a parte que o havia indicado e suas subsidiárias. Revelou, também, que havia trabalhado com alguns desses advogados, sendo que nenhum participava do procedimento arbitral em questão. A parte contrária se opôs à nomeação, que não foi confirmada pela $\mathrm{CCI}^{395}$. De modo similar, a CCI não confirmou a nomeação de árbitro que revelou que um de seus sócios prestava serviços como consultor para uma subsidiária de uma das partes $^{396}$.

No entanto, a CCI confirmou a nomeação de árbitros cujas declarações de independência continham observações imprecisas e que não foram impugnadas por nenhuma das partes, nas seguintes situações: (i) árbitro havia representado, no passado, a parte que o nomeou, em matéria não relacionada com o objeto do processo arbitral, sendo que alguns advogados do seu escritório haviam atuado para empresas pertencentes ao mesmo grupo de sociedades; (ii) várias filiais do escritório de advocacia do árbitro prestavam serviços à parte que o indicou, sendo que nenhum deles relacionava-se com a arbitragem nem envolvia valores significativos; (iii) o escritório do árbitro havia prestado serviços, no

\footnotetext{
${ }^{392}$ Nesse sentido, Betz v. Pankow, 31 Cal. App. 41503 (1995), disponível no endereço eletrônico http://www.leagle.com/decision/1995153431CalApp4th1503 11451; consulta em 21.02.2014.

${ }^{393}$ ANNE MARIE WhiteSELL. Independence... op. cit., p. 22.

${ }^{394}$ ANNE MARIE WhiteSELL. Independence... op. cit., p. 29.

${ }^{395}$ ANNE MARIE WhITESELL. Independence... op. cit., pp. 21-22.

${ }^{396}$ ANNE MARIE WhiteSELl. Independence... op. cit., p. 23. Outros casos, em variações sobre o mesmo critério, são trazidos pela autora.
} 
passado, a uma das afiliadas da parte que o indicou; (iv) o árbitro indicado trabalhava em meio período como consultor da banca de advocacia cujo escritório regional uma vez representou um acionista da parte que o indicou ${ }^{397}$.

Outro caso digno de nota é o African Holding v. Congo, processado segundo as regras ICSID, no qual o investidor impugnou a árbitra indicada pelo Congo, Teresa Giovannini, porque o escritório ao qual ela pertencia havia patrocinado esse Estado em matéria relacionada à controvérsia, sem receber a integralidade dos honorários. Com isso, o escritório era credor do Congo, o que inclinaria a árbitra a julgar a causa procedente para o Estado e aumentar suas chances de receber o crédito. A questão não chegou a ser decidida em razão da renúncia da árbitra ${ }^{398}$.

No caso Middlesex, a aparência de parcialidade foi evidenciada pela relação do árbitro com uma terceira empresa, a qual ele representava contra uma das partes, em litígio não relacionado. O procedimento arbitral iniciou-se em razão de acidente automobilístico sofrido por Stuart Levine, instaurado em face de Middlesex Mutual Insurance Company, Patriot General Insurance Company e Allstate Insurance Company, segundo as regras AAA. Foi selecionado como presidente o árbitro John L. Hartnett, que subscreveu declaração de imparcialidade, na qual deveria apontar tudo o que pudesse refletir na sua habilidade de funcionar como árbitro neutro (os demais árbitros eram, segundo a experiência norte-americana, "não neutros"). No entanto, o árbitro neutro deixou de informar que a empresa seguradora que patrocinava (Harnett, Inc.) estava em litígio com a Middlesex e a Patriot e que ele, pessoalmente, estava sob investigação do Florida Bar por conta desse litígio. Por maioria, o tribunal arbitral proferiu sentença em favor de Levine no valor de USD 1,2 milhão. Middlesex e Patriot formularam pedido de anulação da sentença arbitral na Corte Distrital do Sul da Flórida, que restou acolhido. Posteriormente, a Corte de Apelação do Décimo Primeiro Circuito analisou recurso de apelação e considerou que a atitude do árbitro presidente, ao atuar como advogado da empresa Hartnett e nessa qualidade subscrever duas notificações para a Middlesex sobre prêmios não pagos e, ademais, estar envolvido em procedimento disciplinar no Florida Bar (no qual assinou

\footnotetext{
${ }^{397}$ Todos os casos são trazidos por ANNE MARIE WhITESELL. Independence... op. cit., pp. 16-17.

${ }^{398}$ Caso referido por KAREL DAELE. Challenge... op. cit., pp. 277-278. Referência à renúncia é feita no parágrafo $8^{\circ}$ da sentença; disponível no endereço eletrônico https://icsid.worldbank.org/ICSID/FrontServlet?requestType=CasesRH\&actionVal=showDoc\&docId=DC77 6_Fr\&caseId=C66; consulta em 21.02.2014.
} 
declarações quatro semanas antes da audiência de instrução da arbitragem), não era compatível com a declaração que este fez ao assumir a função de árbitro. Além disso, a Corte de Apelação considerou que os contatos entre o árbitro e a parte contrária ultrapassavam aqueles que ocorreriam no curso normal do exercício profissional do árbitro e que este violou o dever de revelação, de modo que seu comportamento estava circunscrito na descrição da "evidente partiality". A Corte de Apelação afastou, ainda, a alegação de perda da oportunidade de apontar a parcialidade do árbitro presidente, haja vista a insuficiência de demonstração de que os funcionários da Middlesex e da Patriot possuíam conhecimento suficiente dos fatos que poderiam indicar a parcialidade do árbitro $^{399}$.

A prestação de serviços contra uma das partes também pode dar causa à aparência de parcialidade do árbitro. Há registro de que o Board da SCC deu provimento à impugnação do árbitro que estava atuando como legal expert e produzindo uma legal opinion contra a parte que o havia impugnado ${ }^{400}$.

No que concerne a casos práticos, as IBA Guidelines preveem situações descritas na categoria proposta. A Lista Vermelha de Eventos Irrenunciáveis trata da hipótese de (i) prestação regular de assessoria do árbitro à parte que o indicou ou à sua coligada, da qual o árbitro ou a sua empresa obtenham receita financeira significativa ${ }^{401}$. A Lista Vermelha de Eventos Renunciáveis compreende as hipóteses de (ii) o árbitro prestar consultoria ou representar uma das partes ou coligadas, contemporaneamente à $\operatorname{arbitragem~}^{402}$; (iii) o árbitro pertencer ao escritório de advocacia que patrocina uma das partes ${ }^{403}$; (iv) o escritório de advocacia do árbitro ter possuído envolvimento anterior (porém encerrado) na controvérsia, sem o envolvimento pessoal do árbitro ${ }^{404} ;(v)$ o escritório de advocacia do árbitro possuir relacionamento profissional significativo com uma das partes ou

\footnotetext{
${ }^{399}$ Caso Middlesex Mutual Insurance Co. et al v. Stuart Levine, 675 F.2d 1197 (11th Cir. 1982). Decisão disponível no endereço eletrônico https://www.casetext.com/case/middlesex-mut-ins-co-v-levine/; consulta em 21.02.2014.

${ }^{400}$ Caso SCC 46/2007, referido por HeLENA JUNG. SCC practice: challenges to arbitrators - SCC Board decisions 2005-2007, pp. 13-15, disponível no endereço eletrônico http://www.sccinstitute.se/filearchive/2/28190/04-Art32-Jung.pdf; consulta em 21.02.2014.

${ }^{401}$ Seção 1.4 .

${ }^{402}$ Seção 2.3.2.

${ }^{403}$ Seção 2.3.3.

${ }^{404}$ Seção 2.3.5.
} 
$\operatorname{coligadas}^{405}$; e (vi) o árbitro prestar consultoria regular à parte que o nomeou ou coligadas, não recebendo (ou o seu escritório) receita financeira significativa ${ }^{406}$. A Lista Laranja compreende as hipóteses de (vii) o árbitro ter atuado, prestado consultoria ou ter sido consultado, nos três anos anteriores, pela parte que o indicou ou por coligadas, em assunto não relacionado à arbitragem, não possuindo relacionamento constante ${ }^{407}$; (viii) o árbitro ter atuado contra uma das partes ou coligadas, em assunto não relacionado, nos três anos $\operatorname{anteriores}^{408}$; ( $i x$ ) o escritório de advocacia do árbitro ter atuado para uma das partes ou coligadas, nos três anos anteriores, sem o envolvimento do árbitro ${ }^{409} ;(x)$ o escritório de advocacia estar prestando serviços a uma das partes ou coligadas, contemporaneamente à arbitragem, sem a participação do árbitro e sem relacionamento comercial significativo ${ }^{410}$; (xi) um escritório de advocacia, que compartilhe receitas ou honorários com o escritório de advocacia do árbitro, prestar serviços a uma das partes ou coligadas na $\operatorname{arbitragem~}^{411}$; e (xii) o árbitro ou seu escritório representar uma parte ou coligadas regularmente, não se envolvendo com a controvérsia submetida à arbitragem ${ }^{412}$. A Lista Verde traz casos em que (xiii) o escritório de advocacia do árbitro atuou para uma das partes ou coligadas em assunto não relacionado, sem o envolvimento do árbitro ${ }^{413}$; e (xiv) uma empresa em associação ou aliança com o escritório de advocacia do árbitro, mas que não partilha de honorários ou outras receitas, prestar serviços a uma das partes ou coligadas, em assunto não relacionado ${ }^{414}$.

A categoria proposta pelo presente estudo permite a identificação de duas situações distintas: (i) a prestação de serviços diretamente pelo árbitro; e (ii) a prestação de serviços pelo escritório ao qual o árbitro pertence.

\footnotetext{
${ }^{405}$ Seção 2.3.6.

${ }^{406}$ Seção 2.3.7.

407 Seção 3.1.1.

${ }^{408}$ Seção 3.1.2.

${ }^{409}$ Seção 3.1.4.

${ }^{410}$ Seção 3.2.1.

${ }^{411}$ Seção 3.2.2

412 Seção 3.2.3.

${ }^{413}$ Seção 4.2.1.

${ }^{414}$ Seção 4.3.1.
} 
$\mathrm{Na}$ primeira situação, os critérios de análise voltam-se à relação profissional, cuja expressão é avaliada de acordo com o que comumente acontece, a fim de se identificar se o evento ou situação ensejam a aparência de parcialidade, em respeito à proporcionalidade normativa e à coerência e coesão do sistema ao qual a norma criada se integra, de acordo com os seguintes critérios:

- proximidade da relação, sendo que quanto mais próxima e direta ela for, ou seja, quanto menos pessoas ou entidades se interpuserem entre a parte e o árbitro, mais aparente a parcialidade. De fato, mais aparente a parcialidade do árbitro que prestou serviços diretamente à parte do que a uma sociedade coligada, da qual a parte possui pequena participação;

- contemporaneidade da relação, sendo que quanto mais próxima no tempo ao processo arbitral, mais aparente a parcialidade. De fato, mais aparente a parcialidade se a prestação do serviço ocorrer paralelamente à arbitragem do que se tiver ocorrido em um passado distante;

- regularidade da relação, sendo que quanto mais regular ela for, mais aparente a parcialidade. De fato, mais aparente a parcialidade se o árbitro prestar serviços constantes - ou que a atitude do árbitro revele sua intenção de estreitar essa relação ou torná-la regular no futuro próximo - à parte do que se ele tiver prestado um único e pontual serviço;

- afinidade do serviço com a matéria objeto do processo arbitral, sendo que quanto mais afinidade houver, mais aparente a parcialidade. De fato, um serviço prestado que se relacione ao objeto do processo arbitral pode sugerir tanto que o árbitro já possua concepção sobre a controvérsia (seja derivada de conhecimento próprio, seja por conta do quanto lhe foi transmitido pela parte fora do processo), restando imunizado às alegações apresentadas no processo arbitral, quanto que ele tenha interesse em favorecer a parte para quem presta serviços; e

- a representatividade econômica da relação, em critério análogo à substancialidade tratada na categoria anterior e também divisível em um 
componente absoluto, que representa o real ou verdadeiro ("actual") benefício econômico, e um componente relativo, que estabelece uma proporção entre o valor absoluto frente ao status econômico do árbitro.

Na situação em que o escritório do árbitro (e não o árbitro pessoalmente) mantém relação de negócio com a parte, outros critérios se incorporam àqueles acima arrolados:

- o nível de dificuldade na identificação da relação, sendo que quanto mais fácil essa identificação, mais aparente a parcialidade do árbitro. De fato, mais aparente a parcialidade se o escritório do árbitro prestar serviço constante e de vulto para uma das partes, do que se uma das muitas filiais do escritório do árbitro, situada em outro país, prestar serviço à coligada de uma das partes; e

- a relação entre o árbitro e o escritório (sócio, associado, empregado, consultor etc.), pois quanto mais estreita essa ligação, mais aparente a parcialidade do árbitro, seja por conta da maior facilidade de acesso à informação, seja pela possibilidade de que sua remuneração esteja mais intimamente ligada aos proventos auferidos pelos serviços prestados à parte.

Em qualquer das hipóteses, deve ser notado o critério de:

- amplitude do mercado de árbitros disponíveis e sua especialidade na matéria objeto de disputa. De fato, quanto menor o número de especialistas disponíveis para funcionar como árbitro em determinado conflito (por envolver conhecimento técnico, jurídico ou não, detido por poucos), menos aparente será a parcialidade do árbitro e mais provável será o seu contato com as partes ou com os demais envolvidos no processo arbitral. 


\subsubsection{Categoria (1.2) - Relação familiar ou social do árbitro com pessoas ou entidades envolvidas com a parte}

Uma terceira categoria proposta pelo presente estudo congrega as relações preponderantemente não negociais do árbitro com pessoas envolvidas com uma das partes. Não se pode descartar, entretanto, que em algumas ocasiões coexista envolvimento econômico.

Caso representativo dessa coexistência é o Tembec v. US $S^{415}$, no qual sentença proferida em processo arbitral segundo as regras UNCITRAL julgou improcedente o pedido de indenização movido por três empresas canadenses contra os Estados Unidos, pela imposição, por parte destes, de deveres e compensações à importação de madeira canadense. Durante o processo arbitral, os requerentes impugnaram um árbitro sob a alegação de que ele não teria revelado o fato de sua mulher ser prima do presidente George W. Bush, que se envolveu pessoal e diretamente, assim como o primeiro ministro do Canadá, na disputa não vinculante no âmbito do NAFTA a respeito do tema, que veio a ser o tema central da arbitragem. O árbitro não havia revelado, ainda, ter recebido duas importantes nomeações na administração: Legal Adviser of the United States Department of State enquanto George Bush (pai) era vice-presidente dos Estados Unidos; e indicação para o painel de árbitro da ICSID por George W. Bush (filho). O Secretário-Geral do ICSID rejeitou a impugnação, mas, três meses após tal decisão, os requerentes pleitearam a anulação da decisão com base na "evident partiality" prevista na Section 10 do FAA. A Corte Distrital de Colúmbia anulou a decisão arbitral, sob as considerações de que a relação familiar e a proximidade com a família Bush, bem como os cargos na administração pública para os quais o árbitro foi nomeado - agravadas pela não revelação - seriam substrato suficiente para a constatação da evident partiality coibida por lei ${ }^{416}$.

\footnotetext{
${ }^{415}$ Caso TEMBEC INC. $v$ The United States of America, Case No. 05-2345 (D.D.C., 2006). Decisão disponível no endereço eletrônico http://www.state.gov/documents/organization/64890.pdf; consulta em 21.02.2014.

${ }^{416}$ Literalmente: “Mr. Robinson's familial relationship to the President of the United States (undisclosed until questioned); his political and financial support for the President (not disclosed at all); his former position as the Legal Adviser to the U.S. State Department (the office defending the claim); and his appointment to the ICSID Panel of Arbitrators by the President (also undisclosed); all demonstrate a relationship that compromises Mr. Robinson's impartiality in Tembec's suit against the United States".
} 
Por sua vez, a existência de meros contatos sociais entre árbitro e parte é irrelevante para a configuração da aparência de parcialidade. No caso Zhinvali v. Georgia, segundo as regras ICSID, esta última impugnou o árbitro por ele ter participado de uma "dinner party" da qual também participou um executivo sênior de um dos três acionistas da Zhinvali, e pelo fato de o árbitro ter visto esse mesmo executivo em outras reuniões informais. Esse executivo - a quem o impugnante apontou que desenvolveria um papel central na arbitragem e cuja credibilidade seria extremamente importante para a decisão - operava no Chipre, país natal do árbitro, de modo que haveria um risco substancial de que os contatos do árbitro com o executivo afetariam a independência do seu julgamento. A impugnação foi afastada pela falta de demonstração de como encontros casuais e sociais constituiriam manifesta falta de confiança para um julgamento independente, configurando, na verdade, pura especulação $^{417}$.

No mesmo sentido foi a decisão da Corte Distrital do Sul de Nova Iorque no caso PK Time v. Robert, na qual este último requereu o afastamento de dois árbitros sob a alegação (entre outras) de que eles teriam proferido palestra na conferência "International Dispute Resolution", ocorrida em fevereiro de 2012 em Londres, na qual a testemunha técnica de Robert também fez exposição. A conferência foi patrocinada pela empresa Navigant, que empregava a testemunha técnica. A Corte, declarou que PK Time estava claramente especulando sobre a relação entre os árbitros e a testemunha técnica, sendo que "if the courts were to disqualify every arbitrator who has had professional contacts with a party or witness, it would be difficult to maintain the arbitration system" ${ }^{418}$.

Em caso CCI, o árbitro nomeado pelo requerido foi impugnado pelo requerente por alegadamente ter mantido comunicações ex parte com os representantes de uma das partes em um seminário, poucas semanas antes da audiência de instrução. Segundo a alegação do requerente, o árbitro estava no seminário para se patrocinar profissionalmente, de modo que a conversa demonstraria que ele esperava beneficiar-se de uma futura relação com o requerido. Ainda segundo o requerente, o árbitro deveria ter revelado esse contato e, não o fazendo, trazia à tona o questionamento sobre a sua independência. $\mathrm{O}$ árbitro respondeu

\footnotetext{
${ }^{417}$ Decisão não publicada, mas referida por KAREL DAELE. Challenge ... op. cit., pp. 288-289 e por SAMUEL Ross LUTTRELl. Bias... op. cit., p. 226.

${ }^{418}$ Caso PK Time Group, LCC v. Cinette Robert, No. 12 Civ. 8200, 2013 (S.D.N.Y. July 23, 2013). Decisão disponível no endereço eletrônico http://f.datasrvr.com/fr1/613/93802/6_PK_Time_Group_v_Robert.pdf; consulta em 21.02.2014.
} 
que não tinha envolvimento na organização ou promoção da conferência nem com a escolha dos convidados, que seu contato com um dos empregados do requerido foi extremamente limitado e não substancial, e que as alegações careciam de fundamento, configurando mera especulação ${ }^{419}$. A impugnação foi improvida.

Em outro caso ICSID, Asset Recovery v. Argentina, esta impugnou o árbitro presidente, Jaime Irarrázabal Covarrubias, por ele ser membro e diretor da Câmara de Comércio América-Chile (Amcham), o que, segundo a Argentina, ensejaria simpatia e favorecimento dos investidores norte-americanos que controlavam a Asset Recovery, fazendo faltar a necessária imparcialidade. Os coárbitros, ao decidirem o incidente, buscaram ligações mais sólidas do árbitro com a parte, levando em consideração que (i) a Asset Recovery não era membro da Amcham; (ii) o árbitro presidente não tinha relação com a companhia; (iii) não havia evidência de que a Asset Recovery tivesse negócios no Chile; (iv) não havia evidência de que o árbitro presidente participasse de atividades na Argentina; e $(v)$ a Amcham ou seus membros não figuravam como parte no processo arbitral. Assim, julgaram improcedente a impugnação ${ }^{420}$.

Interessante caso, que envolveu a atuação do árbitro no curso do procedimento - agravada pela relação mantida com o árbitro não neutro indicado por uma das partes - levou ao reconhecimento de parcialidade e a anulação da sentença arbitral. Após o término de processo arbitral que envolvia direitos trabalhistas, no qual restou vencedora a United Transportation Union (ou sindicato), a empresa vencida, Pacific \& Arctic Railway And Navigation Company, buscou a anulação da sentença sob a alegação de parcialidade do árbitro presidente (neutro), Arthur Sempliner, devido à sua ligação com o árbitro não neutro indicado pelo sindicato, Kenneth Levin. O árbitro não neutro indicado pela Pacific foi J. W. Mills ${ }^{421}$. Sempliner e Levin eram amigos há 20 anos e, além desse fato, uma série de outros ensejaram a procedência da anulação em primeiro grau, confirmada pela Corte de Apelo do Nono Circuito: (i) Levin telefonou para Sempliner uma série de vezes antes da

\footnotetext{
${ }^{419}$ ANNE MARIE WhiteSELL. Independence... op. cit., pp. 29-30.

${ }^{420}$ Caso referido por KAREL DAELE. Challenge... op. cit. , p. 444. Vide, ainda, Investment Treaty News de 19 de outubro de 2006, disponível no endereço eletrônico http://www.iisd.org/pdf/2006/itn_oct19_2006.pdf; consulta em 21.02.2014.

${ }^{421}$ Caso Pacific \& Arctic Railway And Navigation Co. v. United Transportation Union, 952 F.2d $1144\left(11^{\circ}\right.$ Cir., 1991). Decisão disponível no endereço eletrônico https://law.resource.org/pub/us/case/reporter/F2/952/952.F2d.1144.90-35646.html; consulta em 21.02.2014.
} 
audiência, pouco menos de 24 horas após ter sido proferida decisão em um caso relacionado; (ii) no primeiro dia de audiência, Mills convidou Sempliner para jantar, planejando convidar Levin caso Sempliner aceitasse. Este não aceitou, deixando de mencionar que já havia agendado jantar com Levin; (iii) antes do referido jantar, Levin e Sempliner aguardaram de dez a vinte minutos no quarto desse último, e saíram para jantar juntos, tendo sido surpreendidos pelo advogado da Pacific, que instou o seu árbitro a acompanhá-los; no entanto, Mills não conseguiu encontrá-los; Levin pagou o jantar; e (iv) na manhã seguinte, Levin e Sempliner foram vistos tomando café da manhã juntos. Trazidos esses fatos para a audiência, gerou-se acalorada discussão, sendo que Sempliner proibiu ao advogado da Pacific o registro das suas alegações de impugnação. Ainda no curso da audiência, Sempliner interrompeu Levin e recomendou que a parte que o havia indicado apresentasse apenas parte dos documentos referidos pelo árbitro (não neutro, não se pode esquecer) como provas. As atitudes do árbitro presidente levaram a Pacific e seu advogado a se retirarem da audiência, a qual continuou apenas com os advogados do sindicato. Ao final, Sempliner proferiu decisão a favor do sindicato. Em uma segunda audiência, realizada em Skagway, também sem a participação da Pacific ou de seus advogados, Levin e Sempliner desembarcaram juntos, tendo a audiência durado em torno de uma hora, sem qualquer registro. Além disso, Levin e Sempliner permaneceram no local por vários dias após o término da audiência, tempo em que pescaram e fizeram refeições juntos. Sempliner novamente julgou a favor do sindicato. A ação de anulação da sentença foi julgada procedente diante das impropriedades processuais, agravadas pelas numerosas "ex parte communications" travadas entre o árbitro neutro e o não neutro e pela aceitação, pelo primeiro, de favores e benefícios prestados pelo segundo ${ }^{422}$.

Interessante observar que as IBA Guidelines tratam das hipóteses relativas à categoria proposta pelo presente estudo. Na Lista Vermelha de Eventos Renunciáveis são previstas as hipóteses: (i) de um membro familiar próximo do árbitro possuir interesse financeiro significativo no resultado da demanda ${ }^{423}$; (ii) de o árbitro ou membro familiar próximo

\footnotetext{
${ }^{422}$ No original: " $[i] n$ light of the entire record, including the procedural improprieties; the egregious nondisclosures and unbelievable post facto explanations by Levin and Sempliner; Sempliner's assumption of an advocate's role and active assistance to the union in shaping the record so that it might support his awards; the numerous ex parte communications between Levin and Sempliner; Sempliner's acceptance of gratuities and other favors from Levin or union officials; the actual and demonstrated bias of Sempliner and the irrational awards that are the product Sempliner's bias and favoritism, I conclude that the awards are tainted by the functional equivalent of fraud".

${ }^{423}$ Seção 2.2.2.
} 
possuir relacionamento próximo com terceiro que possa ser responsabilizado em ação de regresso instituída pela parte derrotada na demanda ${ }^{424}$; (iii) de o árbitro possuir relacionamento familiar próximo com uma das partes ou com o administrador, conselheiro ou membro de órgão supervisor ou com qualquer pessoa com influência de controle semelhante sobre uma das partes ou coligadas, ou com advogado que as represente ${ }^{425} \mathrm{e}$; (iv) de um membro familiar próximo do árbitro possuir interesse financeiro significativo em uma das partes ou coligadas ${ }^{426}$. A Lista Laranja contempla a hipótese (vi) de existir um vínculo próximo e pessoal de amizade entre o árbitro e administrador, conselheiro ou membro de órgão supervisor, ou qualquer pessoa com influência de controle semelhante sobre uma das partes ou coligadas, testemunha ou perito, o que se demonstra pelo fato de estes e o árbitro passarem considerável tempo juntos, em atividades não relacionadas a compromissos profissionais de trabalho ou a atividades de entidades de classe ou $\operatorname{organizações~sociais~}^{427}$.

O exame das decisões enquadráveis na categoria sugerida pelo presente estudo demonstra que a comparação entre as particularidades do caso frente ao que comumente acontece para a criação da norma concreta levou em consideração certas particularidades da relação entre árbitro e pessoas envolvidas com a parte, com ênfase nos seguintes critérios:

- intensidade e regularidade da relação e dos contatos, sendo que quanto maior a intensidade e regularidade, mais aparente a parcialidade do árbitro. De fato, mais aparente a parcialidade se o árbitro for familiar do administrador a quem se subordina determinada empresa ou se for seu amigo de longa data, do que se houver conhecido um membro da equipe deste em um evento social; e

- o envolvimento que a pessoa com quem o árbitro se relaciona tem com o litígio, sendo que quanto maior o envolvimento, mais aparente a parcialidade do árbitro. De fato, mais aparente a parcialidade se o árbitro mantém contato com o diretor jurídico da empresa, que trata diretamente do

\footnotetext{
${ }^{424}$ Seção 2.2.3.

${ }^{425}$ Seção 2.3.8.

${ }^{426}$ Seção 2.3.9.

${ }^{427}$ Seção 3.4.3.
} 
conflito, do que se mantiver contato com indivíduo que não tenha qualquer contato com (ou mesmo desconheça) o litígio.

\subsubsection{Categoria (2) - Relação do árbitro ou seu escritório com o advogado que representa a parte ou seu escritório}

Por conta da configuração peculiar do mercado em que os potenciais árbitros estão inseridos - e tendo em vista que geralmente os advogados das partes são os responsáveis pela indicação dos árbitros - a relação entre patronos e árbitros é tomada, pela experiência jurídica, como categoria hábil a ensejar a aparência de parcialidade. A situação é delicada, pois ao mesmo tempo em que os árbitros precisam se inserir em um mercado para assim receberem indicações, devem não se envolver em situações que possibilitem a aparência de parcialidade $^{428}$.

Exemplo disso é o caso Montez v. Prudential Securities, decidido segundo o FAA, no qual a Corte de Apelação do Oitavo Circuito negou o pedido de anulação de sentença arbitral formulado por Montez com fundamento na alegação de que o árbitro, James Benson, não teria revelado que havia trabalhado em empresa que teve negócios com o escritório que patrocinava a Prudential ${ }^{429}$. Benson havia sido o general counsel do banco de investimento Underwood \& Neihaus entre 1977 e 1987, o qual havia contratado o escritório Baker \& Botts, em negociação que envolveu honorários de USD 2.8 milhões. Aqui, mais uma vez, o critério de interesse econômico - aplicado à manutenção da relação do árbitro com o advogado da parte - foi analisado, sendo que a Corte apontou que "there is no indication that Benson had any financial interest" relacionado ao escritório de advocacia, ao seu antigo empregador ou à Prudential, e que o árbitro "have anything to gain from fostering a relationship with either Baker \& Botts or PSI [Prudential]." Além disso, o critério da temporalidade também foi utilizado, tendo a Corte apontado que o antigo empregador do árbitro não possuía negócio com nenhuma das partes na arbitragem, e a relação entre as

\footnotetext{
${ }^{428}$ Sobre o tema, com mais detalhes, vide capítulo 3.3 do presente estudo.

${ }^{429}$ Caso Montez v. Prudential Securities, Inc., 260 F.3d 980 (8th Cir. 2001). Decisão disponível no endereço eletrônico https://law.resource.org/pub/us/case/reporter/F3/260/260.F3d.980.00-3957.html; consulta em 21.02.2014.
} 
sociedades (antiga empregadora do árbitro e escritório de advocacia) se encerrado cinco anos antes do início da arbitragem.

No entanto, no conhecido caso Tecso v. Neoelectra, a Corte de Apelação de Paris entendeu que a atividade do árbitro como of counsel do escritório ao qual pertencia uma das advogadas que defendia (isoladamente, e não em nome do escritório) uma das partes, escritório esse para o qual o árbitro havia prestado consultoria duas ou três vezes como professor e do qual dispunha de endereço eletrônico, seria suficiente - dada a não revelação do árbitro - para caracterizar courant d'affaires e a parcialidade do árbitro. A Corte de Cassação requereu apontamentos da Corte de Apelação, ainda não prestados ${ }^{430}$.

Em geral, o mero fato de o árbitro ter realizado um único serviço com ou para o escritório de advocacia que representa uma das partes não consiste em causa para a aparência de parcialidade, especialmente se o negócio for de minimis, assim como ocorre com a prestação direta de serviço do escritório do árbitro para a própria parte. Tal caso é diferente do ASM Shipping v. TTMI, no qual se reconheceu que o fato de o árbitro ter prestado serviço ao escritório de advocacia de uma das partes (em caso não relacionado), para demonstrar a falta de integridade e desonestidade de uma testemunha que também era testemunha principal do caso que iria julgar, ensejaria a parcialidade do árbitro ${ }^{431}$.

A relação entre árbitro e advogado da parte deve ser negocial ou pessoal, não se podendo sustentar que outras conexões (meramente acadêmicas ou institucionais) ensejem, por si só, a aparência de parcialidade do árbitro. É o quanto restou decidido no caso Red Eléctrica de España v. Iberdrola Distribución Eléctrica ${ }^{432}$, no qual a Corte Provincial de Madri considerou que o fato de o árbitro presidente e um dos coárbitros terem sido designados presidente e vice-presidente de uma associação de arbitragem, da qual era secretário também o advogado de uma das partes, não vulnerava os princípios da independência e imparcialidade impressos na Lei de Arbitragem espanhola. Também a Suprema Corte de Justiça da Costa Rica, na decisão do caso Scott Paper v. Dario Express

\footnotetext{
${ }^{430}$ Para mais detalhes, vide p. 40.

${ }^{431}$ Para mais detalhes, vide nota de rodapé $\mathrm{n}^{\circ} 142$.

${ }^{432}$ Caso trazido por JOSÉ CARLOS FERNÁNDEZ ROZAS. Clearer ethic guidelines and comparative standards for arbitrators, in MigUEL ÁNGEL FERNÁNDEZ-BALLESTEROS; DAVID ARIAS. Liber amicorum Bernardo Cremades. Madrid: La Ley, 2010, p. 433.
} 
R. Castro, registrou que "la condición de profesores universitarios que pueden compartir dos abogados dentro de uma misma casa de estudios, no es un motivo que necesariamente deba generar dudas sobre la imparcialidad (...)" ${ }^{\text {433 }}$. No entanto, é possível pensar em hipótese na qual o árbitro seja professor de um departamento de uma universidade e o advogado de uma das partes seja o professor-chefe do mesmo departamento, com função institucional de atribuir aulas aos colegas e, nesse ponto, influir na sua remuneração. Parece que, aqui, em razão da relação hierárquica, a aparência de parcialidade se mostra com mais força, sendo razoável criar-se norma concreta que coíba tal situação.

O caso ICSID, Universal Compression v. Venezuela retrata bem o tema do relacionamento profissional e pessoal entre advogado e árbitro, bem como outros temas correlatos. No caso, o investidor indicou como árbitro Guido Santiago Tawil, argentino, e a Venezuela, Brigitte Stern, francesa. Tawil revelou, consoante as regras aplicáveis, que não mantinha relação com quaisquer das partes, especificando que (i) havia sido, em duas arbitragens ICSID já encerradas, co-counsel do escritório de advocacia (King \& Spalding) que representava o investidor; (ii) uma das associadas do escritório que representava o investidor, Silvia Marchili, havia trabalhado em seu time em outro escritório, entre os anos de 2003 e 2006; e (iii) juntamente com outros autores, havia contribuído para a primeira e segunda edições da obra "The art of advocacy in international arbitration", da qual Doak Bishop (team leader do King \& Spalding) era um dos coeditores. Stern, em sua revelação, nada apontou, mas dois meses depois apresentou declaração na qual ressaltou que havia sido nomeada pela Venezuela em três arbitragens ICSID, nos anos de 2007, 2008 e 2010. Ambos os árbitros confirmaram a sua imparcialidade. As partes impugnaram o árbitro indicado pela adversária, tendo a impugnação contra a nomeação de Stern apontado que haveria comprometimento da sua imparcialidade e independência especialmente porque $(i)$ além das múltiplas indicações feitas pela Venezuela; (ii) todas elas ocorreram em casos que envolviam assuntos similares, quais sejam, limitação da propriedade por medidas expropriatórias, o que ensejaria a aplicação das Seções 3.1.3 e 3.1.5 das IBA Guidelines; e (iii) em dois dos casos anteriores, a Venezuela havia sido representada pelo mesmo escritório, e em todos eles pelo Advogado Geral, o que ensejaria a aplicação da Seção 3.3.7

\footnotetext{
${ }^{433}$ Caso informado por José Carlos Fernández Rozas. Contenido ético del oficio de árbitro, trabalho apresentado no Congreso Arbitraje La Habana 2010, pp. 20-21; disponível no endereço eletrônico http://www.ohadac.com/congres.html?file=content/ohadac/travaux/congres/Contenido\%20etico\%20del\%20a cceso\%20a\%20la\%20actividad\%20arbitral\%20\%5BJose\%20Carlos\%20Fernandez\%20Rozas\%5D.pdf; consulta em 21.02.2014.
} 
das IBA Guidelines. A impugnação contra a nomeação de Tawil foi baseada na dúvida razoável sobre a sua imparcialidade, em razão $(i)$ da relação profissional entre o árbitro e vários membros do escritório King \& Spalding, que durou pelos menos dez anos e que basicamente consistiu na representação conjunta em arbitragens de investimento, sempre em favor dos investidores (três casos até 2010) e (ii) da relação de trabalho entre o árbitro e a advogada Silvia Marchili, por quatro anos, no escritório do qual Tawil era sócio ao tempo do processo arbitral em questão. $\mathrm{O}$ presidente do tribunal arbitral afastou as impugnações a Stern ${ }^{434}$, apontando que as IBA Guidelines são indicativas, e não mandatórias, e que sua independência e imparcialidade não seriam impactadas pelas múltiplas indicações pela Venezuela, tendo em vista que a árbitra já havia sido indicada para mais de vinte casos ICSID, evidenciando que ela não seria dependente economicamente ou de qualquer outro modo - das indicações da Venezuela. Apontou que a árbitra não poderia ser afastada simplesmente por ter enfrentado questões de fato ou de direito semelhantes em outras arbitragens, visto que as decisões pretéritas não a vinculavam, além do que os casos de desapropriação aparentemente teriam se dado em diferentes ramos empresariais. Por fim, afastou a alegação de múltipla indicação pelo mesmo escritório ensejaria relação de dependência, tendo em vista que a árbitra havia sido indicada múltiplas vezes por vários escritórios. O presidente do tribunal também afastou as impugnações a Tawil, apontando que (i) não existia relação corrente entre o árbitro e o escritório que patrocinava o investidor e (ii) não restou demonstrado que as causas patrocinadas em conjunto envolviam questões legais similares ao caso em questão, de modo que não haveria qualquer vantagem do contato pretérito do árbitro com os advogados. Sobre a relação entre árbitro e a associada do King \& Spalding, o presidente considerou difícil imaginar que a imparcialidade do árbitro seria afetada pela relação existente cinco anos antes entre o árbitro e um dos muitos advogados da sua equipe na época $^{435}$.

\footnotetext{
${ }^{434}$ Caso Universal Compression International Holdings, S.L.U. v. The Bolivarian Republic of Venezuela, ICSID Case No. ARB/10/9. Decision on the proposal to disqualify Prof. Brigitte Stern and Prof. Guido Santiago Tawil, Arbitrators, disponível no endereço eletrônico https://icsid.worldbank.org/ICSID/FrontServlet?requestType=CasesRH\&actionVal=showDoc\&docId=DC24 11_En\&caseId=C1021; consulta em 21.02.2014.

${ }^{435}$ Críticas a essa decisão, especialmente por ela desconsiderar que a relação de parceria de Tawil com o escritório King \& Spalding durou oito anos e meio - o que seria suficiente para que fosse construída uma forte relação pessoal e para que o árbitro estabelecesse uma natural simpatia pelas alegações do seu antigo parceiro - foram feitas por KAREL DAELE. Challenge... op. cit., pp. 295-296.
} 
Demonstração da existência de contatos muito próximos ocorreu no caso $C$. Vick v. North Carolina Farm Bureau, processado segundo as regras da AAA. Nele, o árbitro apontado pela instituição, Mark C. Kirk, revelou: "I know and have worked with counsel for both Parties. I also know Mr. Aldridge [o sócio do escritório que representava a Farm Bureau] socially. Such relationships will not affect my ability to render a fair and impartial determination in this proceeding." Antes da audiência, a sociedade Vick impugnou o árbitro em razão do seu relacionamento com a advogada da parte, impugnação essa afastada pela AAA, com a continuação da audiência. Vencida na arbitragem, após a audiência, restou demonstrado que o árbitro não havia revelado diversos eventos que o ligavam aos sócios do escritório de advocacia que representou a Farm Bureau, especialmente à sócia Stephani Humrickhose: (i) o árbitro conhecia a advogada desde o primeiro ano da faculdade; (ii) a advogada havia tido encontros com o colega de quarto do árbitro no tempo da faculdade; (iii) a advogada e o árbitro pertenciam à mesma fraternidade estudantil; (iv) o árbitro era amigo do marido da advogada, a quem se referia pelo primeiro nome, do qual conhecia as alergias e a quem caracterizava como "um dos seres humanos mais divertidos na face da Terra"; (v) o árbitro e a advogada jantavam juntos e iam a jogos de futebol juntos; (vi) o árbitro e a advogada trocavam presentes nos aniversários dos respectivos filhos e seus filhos brincavam juntos; (vii) a mulher do árbitro havia viajado para Nova Iorque e se hospedado na residência dos pais da advogada; (viii) o árbitro e a advogada tinham amigo em comum, associado ao escritório da advogada; (ix) o árbitro admitiu que a advogada indicava casos para seu escritório, recebidos pelo seu sócio Howard Kahn; e $(x)$ a advogada representou o árbitro em procedimento criminal $\mathrm{e}$ apresentou manifestação em seu interesse para Cortes Distritais. Ademais, restou comprovado que outro sócio da banca que representava a Farm Bureau, Gregory Crampton, foi testemunha técnica no processo criminal em que o árbitro se viu envolvido, encontrando-se com o árbitro, para esse fim, várias vezes. Assim, diante das numerosas relações sociais, negociais e profissionais entre o árbitro e o escritório que patrocinava a Farm Bureau - nenhuma delas revelada - a Corte de Apelação da Carolina do Norte ${ }^{436}$ entendeu haver fundamento provável a afetar a imparcialidade ou para razoavelmente criar a aparência de imparcialidade, julgando procedente a demanda para a anulação da sentença arbitral.

\footnotetext{
${ }^{436}$ Caso William C. Vick Const. Co. v. North Carolina Farm Bureau Federation, 472 S.E.2d 346 (N.C. App. 1996). Decisão disponível no endereço etrônico http://www.leagle.com/decision/1996818472SE2d346_1745; consulta em 21.02.2014.
} 
Também é interessante o caso anedótico em que o árbitro foi flagrado pelas câmeras de segurança ao entrar à noite e sair na manhã seguinte, por duas vezes, da suíte ocupada por um das advogadas que atuavam no caso. A advogada afirmou que o árbitro havia passado com ela a primeira noite porque ela não se sentia bem e o árbitro ficou preocupado com a sua saúde; justificou a segunda noite afirmando que o árbitro havia perdido a sua pasta, não a encontrando até horário avançado, quando não conseguiu mais local para pernoitar, razão pela qual a advogada, preocupada, ofereceu-se para dividir novamente o quarto com o árbitro $^{437}$.

Em caso CCI, a Corte não confirmou a nomeação do árbitro que deixou de revelar que constava como of counsel no endereço eletrônico do escritório de advocacia que representava uma das partes, além de usar seu endereço físico e telefone ${ }^{438}$. Em outro caso CCI, o árbitro não foi confirmado porque estava atuando em dois casos como co-counsel do advogado dos requeridos, em dois outros casos como co-counsel de colegas do advogado do requerido; e em outros dois casos judiciais, contra o escritório que estava representando os requerentes ${ }^{439}$. Outros casos de não confirmação envolveram: (i) a amizade íntima do árbitro com um dos advogados de uma das partes ${ }^{440}$; (ii) o fato de a mulher do árbitro ser uma das sócias do escritório de advocacia que defendia uma das $\operatorname{partes}^{441}$; (iii) a situação de o árbitro não ter revelado ter emitido pareceres para um cliente do escritório de uma das partes, além de ter atuado como co-counsel desse escritório em dois casos não relacionados, e ser coeditor, ao lado do advogado desse escritório de advocacia, de um livro sobre arbitragem ${ }^{442}$; e (iv) o fato de o árbitro não ter revelado haver trabalhado, seis anos antes da instauração do processo arbitral, no mesmo escritório de

\footnotetext{
${ }^{437}$ Caso referido por RICHARD B. SCHIMITT. Suite sharing: friendship with winning lawyer imperils huge victory, in Wall Street Journal, 14.02.1990, apud WILLIAM W. PARK. Arbitrator integrity ... op. cit., p. 641, nota 31 .

${ }^{438}$ ANNE MARIE WhiteSELL. Independence... op. cit., p. 21.

${ }^{439}$ ANNE MARIE WHITESELL. Independence... op. cit., p. 25.

${ }^{440}$ JASON FRY; SIMON GREENBERG. The arbitral tribunal: applications of articles 7-45 of the ICC Rules in recent cases; in ICC International Court of Arbitration bulletin, v. 20, n. 2, 2009, p. 20.

${ }^{441}$ JASON FRY; SIMON GREENBERG. The arbitral ... op. cit., p. 20.

${ }^{442}$ ANNE MARIE WhiteSELl. Independence... op. cit., p. 18.
} 
advocacia do advogado de uma das partes, mesmo que não tivesse mais mantido qualquer relação profissional com ele $\mathrm{e}^{443}$.

A Corte da CCI, contudo, confirmou a nomeação de árbitros em casos que envolveram: $(i)$ árbitro que foi nomeado revisor oficial do anteprojedo de lei que havia sido preparado por um sócio do escritório de advocacia de uma das partes, além de ter sido coautor de várias publicações com ele ${ }^{444}$; (ii) árbitro que havia sido coautor de um tratado com o advogado de uma das partes, além de ter trabalhado com ele em um mesmo escritório, em relação que havia terminado nove anos antes do início da $\operatorname{arbitragem}^{445}$; (iii) árbitro que não revelou que ele e o advogado de uma das partes eram membros do parlamento e do mesmo partido político ${ }^{446}$; e (iv) árbitro que revelou participar de várias organizações profissionais com o advogado de uma das partes, sendo que ambos haviam sido coárbitros em dois processos arbitrais já encerrados ${ }^{447}$.

A CCI afastou árbitros já confirmados nos casos em que: ( $i$ ) o árbitro informou ter tomado conhecimento que uma das filiais estrangeiras do seu escritório de advocacia, que possuía mais de setecentos advogados, havia conduzido transação que envolvia a parte que o havia indicado, mas que não tinha qualquer relação com o objeto da arbitragem, sendo que o escritório prestou declaração de que havia tomado os mais estritos procedimentos de confidencialidade (“Chinese wall”) para isolar o coárbitro de qualquer contato com a matéria $^{448}$; (ii) o árbitro informou, após ter sido confirmado, que havia se envolvido, na qualidade de antigo consultor legal da parte que o indicou, no desenvolvimento do projeto que levou à controvérsia ${ }^{449}$; (iii) o árbitro não revelou que, contemporaneamente ao processo em questão, era co-counsel em outro processo, juntamente com o advogado da parte que o nomeou ${ }^{450}$; e (iv) o árbitro constava como advogado e consultor no endereço eletrônico do escritório de advocacia da parte que o nomeou, embora ele fosse professor

\footnotetext{
${ }^{443}$ ANNE MARIE WhITESELL. Independence... op. cit., p. 18.

${ }^{444}$ ANNE MARIE WHITESELL. Independence... op. cit., p. 16.

445 ANNE MARIE WHITESELL. Independence... op. cit., p. 16.

${ }^{446}$ ANNE MARIE WHITESELL. Independence... op. cit., p. 16.

447 ANNE MARIE WHITESELL. Independence... op. cit., pp. 18-19.

${ }^{448}$ ANNE MARIE WHITESELL. Independence... op. cit., pp. 27-28.

449 ANNE MARIE WHITESELL. Independence... op. cit., p. 28.

${ }^{450}$ ANNE MARIE WHITESELL. Independence... op. cit., p. 28.
} 
universitário e somente emitisse opiniões legais e respondesse a consultas para escritórios que remuneravam a universidade, consoante um formato estabelecido em lei, a qual exigia que ele permanecesse independente de qualquer escritório que contratasse seus serviços de consultoria $^{451}$.

Há registro de impugnação baseada na relação entre coárbitro e advogado que foi denegada pela Corte da CCI, em caso que envolveu árbitro nomeado pela parte, que não revelou relação acadêmica com advogado do escritório de advocacia da parte que o indicou, por força da qual supervisionou a tese de doutorado e, segundo a impugnação, teria financiado a publicação da tese. O coárbitro informou que sua relação com o advogado era meramente acadêmica, tal como mantinha com diversos outros alunos. Uma carta do editor afirmou que o coárbitro não havia contribuído financeiramente com a tese ${ }^{452}$.

No entanto, foi anulada sentença arbitral proferida em processo no qual o árbitro, Gerald Weisbach, apresentou revelação parcial e incompleta, na qual omitiu que possuía uma relação "familiar" com o advogado de uma das partes (David Baskin), inclusive tendo sido namorado da irmã desse advogado ${ }^{453}$.

Para configurar a aparência de parcialidade, é necessária a demonstração de uma verdadeira relação entre árbitro e advogado ou escritório que representa uma das partes. Não bastam meras inferências derivadas de contatos pontuais. Isso fica claro na decisão do caso Trevino Hernandez v. Smart \& Final, na qual o requerido pleiteou a anulação de sentença arbitral proferida em processo CCI, com fundamento na Section 10(a)(2) do FAA, à Corte Distrital do Distrito Sul da Califórnia, sob a afirmação que um dos três árbitros era o presidente da US-Mexico Bar Association, enquanto o sócio do escritório de advocacia que representava o requerente era o vice-presidente da mesma associação. A Corte entendeu que a evidente parcialidade requerida pela lei teria que decorrer, no mínimo, de uma relação financeira, de emprego ou pessoal entre o árbitro e a parte ${ }^{454}$.

\footnotetext{
${ }^{451}$ ANNE MARIE WhiteSELl. Independence... op. cit., pp. 28-29.

${ }^{452}$ ANNE MARIE WHITESELl. Independence... op. cit., p. 30.

${ }^{453}$ Caso La Serena Properties et al v. Gerald Weisbach et al, 186 Cal. App. 4th 893 (Cal. Ct. App. 2010). Decisão disponível no endereço eletrônico http://www.leagle.com/decision/In\%20CACO\%2020100804003; consulta em 21.02.2014.

${ }^{454}$ Caso Trevino Hernandez, S. De R.L. de C.V. v. Smart \& Final, Inc., 2010 WL 2505683, (S.D.Cal June 17, 2010), comentado por JuAn M. AlCALÁ; CAMIlo CARdozo; Claudia T. SAlOMOn. Chapter 3 - arbitrator
} 
O mesmo contato pontual - qualificado pela falta de proximidade do árbitro com o advogado em razão de pessoa interposta - ficou demonstrado no caso SCC 001/2010 ${ }^{455}$. Nele, o árbitro presidente foi impugnado porque, em outra arbitragem, sua mulher atuava como advogada adversária do advogado do impugnante e foi, pelo presidente daquele painel, duramente criticada por ensejar forte conflito entre os advogados. Com isso, o impugnante considerou que a mulher do árbitro teria aversão ao representante, o que poderia influenciar o árbitro. A impugnação foi rejeitada.

As IBA Guidelines ilustram diversas situações possíveis, enquadráveis na categoria em questão. A Lista Vermelha de Eventos Renunciáveis contempla as hipóteses em que: $(i)$ o árbitro representa o advogado ou escritório de advocacia que atua como consultor jurídico para uma das partes ${ }^{456}$; e (ii) o árbitro é advogado no escritório de advocacia que patrocina uma das partes ${ }^{457}$. A Lista Laranja faz previsões aplicáveis quando: (iii) o escritório de advocacia do árbitro compartilhar receitas ou honorários com o escritório de advocacia que prestar serviços a uma das partes ou coligadas perante o tribunal arbitral ${ }^{458}$; (iv) o árbitro e o consultor jurídico de uma das partes são membros da mesma câmara de advogados (“barrister chamber") ${ }^{459}$; (v) um membro familiar próximo do árbitro é sócio ou empregado do escritório de advocacia que representa uma das partes, não prestando serviços na controvérsia ${ }^{460}$; e (vi) existir um vínculo próximo de amizade entre um árbitro e o consultor jurídico de uma das partes, demonstrável pelo fato de regularmente passarem tempo considerável juntos, em atividades não relacionadas a compromissos profissionais ou a atividades de entidades de classe ou organizações sociais ${ }^{461}$. A Lista Verde compreende as hipóteses de: (vii) o árbitro possuir relacionamento com o consultor jurídico

disclosure standards in a state of flux, in GRANT HANESSIAN (Ed.). ICDR awards and commentaries. New York: JurisNet, 2012, pp. 80-81.

${ }^{455}$ Caso 001/2010 (nomes omitidos), referido por NIKLAS LINDSTRÖM. Challenges to arbitrators - decisions by the SCC Board during 2008-2010, pp. 9-10; disponível no endereço eletrônico http://www.skiljedomsföreningen.se/\$2/file/challenges-to-arbitrators-decisions-by-the-scc-board-during20081.pdf; consulta em 21.02.2014.

${ }^{456}$ Seção 2.3.2.

${ }^{457}$ Seção 2.3.3.

${ }^{458}$ Seção 3.2.3.

${ }^{459}$ Seção 3.3.2.

${ }^{460}$ Seção 3.3.5.

${ }^{461}$ Seção 3.3.6. 
de uma das partes em virtude de filiação na mesma entidade de classe ou organização social $^{462}$; e (viii) o árbitro e o consultor jurídico de uma das partes já terem atuado juntos em outro tribunal arbitral ${ }^{463}$.

O exame das decisões enquadráveis na categoria sugerida pelo presente estudo revela que elas giram em torno de: (i) uma relação familiar próxima do árbitro com o advogado do escritório que patrocina uma das partes; (ii) uma relação de amizade próxima (ou mesmo amorosa) do árbitro com advogado pertencente ao escritório que patrocina uma das partes; ou (iii) uma relação negocial do árbitro (ou seu escritório) com o advogado ou escritório que patrocina uma das partes, com destaque aos seguintes critérios:

- proximidade da relação, sendo que quanto mais próxima e direta ela for, ou seja, quanto menos pessoas ou entidades se interpuserem entre o advogado e o árbitro, mais aparente a parcialidade.

- intensidade e regularidade da relação e dos contatos, sendo que quanto maior a intensidade e regularidade, mais aparente a parcialidade do árbitro;

- contemporaneidade da relação, sendo que quanto mais próxima no tempo ao processo arbitral, mais aparente a parcialidade;

- a duração e a regularidade da relação, sendo que quanto mais longa e regular ela for, mais aparente a parcialidade;

- o número de casos envolvidos na relação, sendo que quanto maior o número, mais aparente a parcialidade; e

- a participação do árbitro na prestação dos serviços ao ou com o escritório de advocacia que patrocina uma das partes, sendo que quanto maior a participação, mais aparente a parcialidade.

\footnotetext{
462 Seção 4.4.1.

${ }^{463}$ Seção 4.4.2.
} 
Ainda é possível, dentro da categoria, que advogado e árbitro tenham trabalhado juntos em um mesmo escritório (que não represente nenhuma das partes). Se a relação entre os profissionais for muito próxima, ela pode ser reconduzida à relação de amizade, já tratada.

\subsubsection{Categoria (3.1) - Contato anterior do árbitro com o litígio, com causas derivadas ou com questões similares}

A terceira categoria identificável pela análise de casos concretos é mais heterogênea que as demais por ser residual, os seja, incluir todos os casos não redutíveis às categorias anteriores (as quais se ligam preponderantemente às relações do árbitro com a parte ou com o advogado e pessoas ou entidades do seu entorno). Aqui, a aparência de parcialidade deriva - preponderantemente, não se pode esquecer - de eventos distintos. Não se pode negar que o contato do árbitro com a causa anteriormente à sua nomeação pode se dar, justamente, por conta do início de uma relação do árbitro com a parte (uma consulta, por exemplo), mas a tônica de análise não se dá pelo dito início de relação (que pode ser incipiente a ponto de não "positivar" nenhum dos critérios de análise referentes à categoria $^{464}$ ) e sim pelo conhecimento da narrativa da parte sobre o litígio antes e fora do processo arbitral, o que pode levar à aparência de imunização do árbitro quanto aos argumentos da parte contrária.

Assim, mesmo que possa existir algum nível de relação entre a parte (ou seu advogado) e o árbitro, é o conhecimento prévio do litígio, tomado em si mesmo, o que justifica a eleição da categoria ora tratada. Foi o que ocorreu em casos CCI, nos quais a Corte deixou de confirmar a nomeação de árbitro em razão de $(i)$ o árbitro nomeado pelo requerido ter revelado que teve reunião com este para discutir a possibilidade de representá-lo no processo arbitral, tendo o requerido, no entanto, contratado outro advogado ${ }^{465}$; e, em outro caso, de (ii) envolvimento anterior do árbitro com a causa na situação em que este também era juiz vinculado ao Estado que, no procedimento arbitral, era o requerido, envolvendo-se em decisão proferida em processo judicial ligado à arbitragem, tendo a parte que impugnou

\footnotetext{
${ }^{464}$ Sobre os critérios, vide capítulo 3.4.2 do presente estudo.

${ }^{465}$ ANNE MARIE WHITESELL. Independence... op. cit., p. 23.
} 
sua nomeação alegado que, na qualidade de juiz, o árbitro poderia ter tido acesso a informações que não estariam disponíveis aos demais árbitros ${ }^{466}$.

Se é notável a aparência de parcialidade do árbitro que já conhece a causa, o mesmo não pode ser dito sobre o árbitro que conhece parte da documentação ou testemunha que foi ou venha a ser utilizada no processo arbitral. A extensão do conhecimento do árbitro, seu contato com as provas e a relação delas com o conflito devem ser analisadas em cada caso concreto. Sobre o exame prévio de documentação, há caso CCI no qual a nomeação do árbitro não foi confirmada pela Corte porque ele já havia composto tribunal em outro processo arbitral, também CCI, que envolvia litígio derivado de contrato entre o requerente da nova arbitragem e seus contratados; na nova arbitragem, esse mesmo requerente (representado por advogados diferentes) litigava com o seu contratante; o contrato entre o requerente e seus contratados era derivado do contrato entre o requerente e seu contratante (subcontratação), razão pela qual o árbitro, no processo anterior, poderia ter examinado documentos e decidido sobre questões ligadas à nova arbitragem, até porque, embora os contratos não fossem os mesmos, eles continham cláusulas espelhadas ${ }^{467}$. No entanto, há o caso Qatar v. Creighton, no qual o requerente pleiteou à Corte de Apelação de Paris a anulação da sentença arbitral porque (entre outras razões) um dos árbitros havia participado de tribunal em caso CCI relacionado, cujo foco era o conflito entre o contratado e o subcontratado relativamente à construção de um hospital no Qatar. A arbitragem em questão tinha como foco os conflitos entre o contratado e o Qatar. A Corte de Apelação considerou que a imparcialidade do árbitro não havia sido afetada pela arbitragem anterior, tendo em vista que as decisões concernentes à relação entre contratado e subcontratado não eram determinantes para a fixação dos direitos e obrigações entre o contratado e o Qatar ${ }^{468}$. Sobre o conhecimento do árbitro a respeito de testemunha (e a atuação do árbitro, em processo anterior, para desqualificá-la), há o caso ASM Shipping v. TTMI, já descrito ${ }^{469}$.

\footnotetext{
${ }^{466}$ ANNE MARIE WHITESELL. Independence... op. cit., p. 21.

${ }^{467}$ ANNE MARIE WHITESELL. Independence... op. cit., pp. 25-26.

${ }^{468}$ Caso Société Creighton Ltd. v. Ministre des Finances de l'Etat du Qatar. O Qatar buscou a anulação da decisão da Cour d'Apell, rejeitada pela Cour de Cassation em decisão de 16.03.1999; disponível no endereço eletrônico http://lexinter.net/JPTXT/independance de l'arbitre.htm; consulta em 21.02.2014.

${ }^{469}$ Para mais detalhes, vide nota de rodapé $n^{\circ} 142$.
} 
Em causa decorrente de outra já julgada, a Corte da CCI não confirmou a nomeação de árbitro que já havia funcionado como árbitro único em um processo CCI anterior, entre as mesmas partes, no qual o requerido havia sido condenado a pagar indenização por quebra de contrato, condenação que, não cumprida, levou o requerente a instaurar nova arbitragem, desta vez para resilição do contrato ${ }^{470}$.

No caso ICSID PIP v. République Gabonaise, esta impugnou o árbitro, Ibrahim Fadlallah, indicado pela sua adversária, por ele já ter figurado como presidente no tribunal do caso Transgabonais v. Gabon, outro processo arbitral ICSID cuja decisão, desfavorável ao Estado, era objeto de procedimento de anulação. A impugnação do Gabão continha, como principais fundamentos $(i)$ o fato de o profissional ter atuado em caso que envolvia questões similares sobre concessões estatais, tomadas pelo mesmo governo, ao mesmo tempo e sob o mesmo contexto político e (ii) o árbitro já havia tomado conhecimento de alegações de fato e de direito relativas ao tema da arbitragem, convencendo-se de que a retomada da concessão constituiria expropriação, tese pela qual se decidiu. Os coárbitros seguiram entendimentos opostos quanto à impugnação, que foi levada ao Presidente do Conselho Administrativo do ICSID. Este se baseou na primeira decisão a respeito da proposta de desqualificação nos casos Suez v. Argentina para concluir que o fato de o árbitro ter tomado posição a respeito de uma das partes não seria suficiente para se concluir pela falta de imparcialidade ${ }^{471}$. Sobre a questão do possível prejulgamento a respeito de o ato governamental consistir expropriação, o Presidente do Conselho considerou que essa seria uma questão que dependeria preponderantemnte dos fatos de cada caso, a serem decididos de maneira colegiada em cada tribunal.

A CCI, no entanto, tem tomado posição mais cautelosa, não confirmando a indicação de árbitro que não foi impugnado por nenhuma das partes no caso em que este revelou ter atuado em outro procedimento arbitral não diretamente ligado à arbitragem, mas que envolvia fatos similares. As ações representativas do capital social do requerente no outro procedimento era integralmente detida pela parte no procedimento novo e, nas duas arbitragens, as partes envolvidas eram do mesmo país, o objeto da disputa era do mesmo

\footnotetext{
${ }^{470}$ ANNE MARIE WHITESELL. Independence... op. cit., p. 26.

${ }^{471}$ Caso PIP Sàrl c. République Gabonaise (Affaire CIRDI ARB/08/17). Decisão sobre o pedido de desqualificação de árbitro de 12 de novembro de 2009, disponível no endereço eletrônico http://www.italaw.com/sites/default/files/case-documents/ita0620.pdf; consulta em 21.02.2014.
} 
tipo e os requerentes eram representados pelo mesmo advogado, havendo risco de que o árbitro tivesse acesso a informações não disponíveis aos membros do novo tribunal $\operatorname{arbitral}^{472}$.

Também foi em procedimento CCI que ocorreu a recusa à confirmação de árbitro que revelou já ter atuado como coárbitro nomeado pelo requerente em caso relacionado, também em CCI, cuja sentença servia como fundamento para os requerimentos no novo procedimento $^{473}$.

A gravidade do evento e a possibilidade de que ele aparente a parcialidade depende dos fatos concretos e dos valores ponderados. Em caso CCI, houve a confirmação do árbitro indicado pelo requerido, que havia mantido contato com o respectivo advogado, o qual havia sido contatado por tal advogado apenas para verificar a disponibilidade do árbitro para a causa, nada tratando sobre o mérito ${ }^{474}$. No entanto, em casos nos quais o contato foi mais profundo, a CCI não confirmou o árbitro. Foi o que aconteceu no caso em que o árbitro nomeado pelo requerido revelou que havia tido reunião com o último, na qual foi discutida a possibilidade de ele, árbitro, representar o requerido na arbitragem. O requerido contratou outro advogado. O requerente impugnou a confirmação do árbitro, impugnação esta acatada pela $\mathrm{CCI}^{475}$.

No caso STMicroelectronics v. Credit Suisse, a Corte de Apelação do Segundo Circuito julgou improcedente o pedido de anulação de sentença arbitral, pedido esse amparado no fato de o árbitro, John J. Duval, não ter revelado seu trabalho como perito em questões legais análogas àquelas discutidas na arbitragem em cujo painel figurou. Na concepção do autor da demanda anulatória, esse evento sugeria a existência de preconcepções do árbitro a respeito de questões de direito ${ }^{476}$. A Corte destacou que, assim como para os juízes, é virtualmente impossível que o árbitro não tenha preconcepções acerca de questões jurídicas.

\footnotetext{
${ }^{472}$ ANNE MARIE WhITESELL. Independence... op. cit., p. 22.

${ }^{473}$ ANNE MARIE WHITESELL. Independence... op. cit., p. 21.

${ }^{474}$ ANNE MARIE WhiteSELL. Independence... op. cit., p. 26.

${ }^{475}$ ANNE MARIE WhiTESELL. Independence... op. cit., p. 24.

${ }^{476}$ Caso STMicroelectronics, N.V. v. Credit Suisse Securities LLC, Docket No. 10-3847-cv (2 ${ }^{\circ}$ Cir 2012). Decisão disponível no endereço eletrônico http://docs.justia.com/cases/federal/appellate-courts/ca2/103847/10-3847_opn-2011-06-02.pdf?1307056392; consulta em 21.02.2014.
} 
No caso Tidewater v. Venezuela, um dos fundamentos para a impugnação da árbitra Brigitte Stern foi o fato de ela compor o tribunal arbitral em outro caso ICSIC que envolvia questão de direito similar, qual seja, se a lei de investimento venezuelana configurava suporte para a instauração de arbitragem relativamente à matéria. Como o outro processo estava mais avançado e nele essa questão havia sido decidida primeiramente, a Venezuela afirmou que a árbitra já estaria comprometida com um prejulgamento da questão. Os coárbitros que decidiram a impugnação afirmaram que decisão pretérita sobre circunstâncias de fato próximas, mas que envolvem diferentes partes e, especialmente, questões de direito, não ensejam parcialidade do julgador. Mais: os coárbitros apontaram que na arbitragem de investimentos e nas arbitragens comerciais seria impraticável o afastamento do árbitro que já tivesse analisado questões de fato ou de direito similares em arbitragens concorrentes ou consecutivas, observando, por fim, que nem o árbitro, nem o tribunal arbitral estão vinculados ao entendimento de outro tribunal quanto às questões de direito $^{477}$. Raciocínio equivalente sustentou a decisão do Presidente do Conselho Administrativo do ICSID no caso Universal Compression v. Venezuela ${ }^{478}$.

No caso Technip v. Asmidal, a Corte de Apelação de Paris julgou improcedente demanda que visava negar a exequibilidade de sentença proferida em processo arbitral CCI, na qual o árbitro havia participado de processo paralelo (também CCI) que envolvia o mesmo projeto de construção e as mesmas partes. A Corte entendeu que um árbitro pode participar de arbitragens paralelas conquanto não prejulgue questões, ou seja, que as decisões tomadas no primeiro processo não tenham consequências lógicas para a decisão das questões discutidas no segundo $^{479}$. No mesmo sentido foi o julgamento do caso Qatar $v$. Creighton $^{480}$, no qual o requerido havia nomeado o mesmo árbitro em três outros processos

\footnotetext{
${ }^{477}$ Caso Tidewater Inc. v. The Bolivarian Republic of Venezuela (ICSID Case No ARB/10/5). Decision on claimants' proposal to disqualify Prof. Brigitte Stern, arbitrator, disponível no endereço eletrônico http://italaw.com/sites/default/files/case-documents/ita0860.pdf; consulta em 21.02.2014.

${ }^{478}$ Caso Universal Compression International Holdings, S.L.U. v. The Bolivarian Republic of Venezuela, ICSID Case No. ARB/10/9. Decision on the proposal to disqualify Prof. Brigitte Stern and Prof. Guido Santiago Tawil, arbitrators, disponível no endereço eletrônico https://icsid.worldbank.org/ICSID/FrontServlet?requestType=CasesRH\&actionVal=showDoc\&docId=DC24 11 En\&caseId=C1021; consulta em 21.02.2014.

${ }^{479}$ Caso Compagnie Française d'Etudeset de Construction Technip v. Entreprise Natinale des Engrais et des Produits Phitasanitaires (Asmidal). Decisão de 02.04.1998, disponível no endereço eletrônico http://www.newyorkconvention1958.org/index.php?lvl=notice_display\&id=153; consulta em 21.02.2014.

${ }^{480}$ Caso State of Qatar v. Creighton Ltd. Cour de Cassation, de 16.03.1999, disponível no endereço eletrônico http://lexinter.net/JPTXT/independance de l'arbitre.htm; consulta em 21.02.2014.
} 
- todos derivados do mesmo contrato. A Corte de Cassação manteve a decisão da Corte de Apelação de Paris, considerando que não haveria base para se questionar a imparcialidade de um árbitro que houvesse figurado no mesmo papel em procedimentos anteriores, a não ser que tal árbitro tivesse que decidir sobre a responsabilidade de uma terceira parte.

No caso Suez v. Argentina, o primeiro pedido para o afastamento da árbitra Gabrielle Kaufmann-Kohler formulado pela Argentina teve como fundamento o fato de ela, árbitra, ter decidido contra a Argentina em processo arbitral anterior (Vivendi v. Argentina), condenando-a ao valor de USD 105 milhões, em sentença que seria, segundo a consideração da Argentina, tão falha na solução das questões de fato e na avaliação das provas que a participação da árbitra revelaria, prima facie, a falta de imparcialidade. Os demais árbitros afastaram a alegação de falha na decisão anterior - até porque a sentença havia sido unânime - e apontaram que a diferença entre o entendimento da parte e o entendimento do julgador a respeito das provas não significa erro de julgamento ${ }^{481}$. Os árbitros passaram, então, a analisar se a participação da árbitra em procedimento anterior do qual a Argentina era parte macularia ou não a sua imparcialidade ou, de modo geral, se o fato de um árbitro decidir questões de fato e de direito, bem como com base nelas julgar contra as alegações de uma parte significaria que ele não seria imparcial para decidir litígio da mesma parte em outro processo. A resposta foi negativa, pois "[a] finding of an arbitrator's or a judge's lack of impartiality requires far stronger evidence than that such arbitrator participated in a unanimous decision with two other arbitrators in a case in which a party in that case is currently a party in a case now being heard by that arbitrator or judge. To hold otherwise would have serious negative consequences for any adjudicatory system."

As IBA Guidelines contêm previsões relativas ao conhecimento prévio do árbitro a respeito do litígio. A Lista Vermelha de Eventos Renunciáveis faz referência ao envolvimento prévio do árbitro na mesma causa ${ }^{482}$. A Lista Laranja faz referência às hipóteses de $(i) \mathrm{o}$ árbitro já ter exercido essa função em outro processo arbitral sobre litígio relacionado que

\footnotetext{
${ }^{481}$ Caso Compañia de Aguas del Acoñquija S.A and Vivendi Universal S.A. v. Argentine Republic (ICSID Case $\left.\mathrm{N}^{\circ} \mathrm{ARB} / 97 / 3\right)$; e Suez, Sociedad General de Aguas de Barcelona S.A. and Vivendi Universal S.A v. Argentine Republic (ICSID Case No. ARB/03/19). Decision on the proposal for the disqualification of a member of the arbitral tribunal, de 02.10.2007, disponível no endereço eletrônico https://icsid.worldbank.org/ICSID/FrontServlet?requestType=CasesRH\&actionVal=showDoc\&docId=DC68 9_En\&caseId=C18; consulta em 21.02.2014

${ }^{482}$ Seção 2.1.2.
} 
envolva a parte ou afiliada, nos três anos anteriores ${ }^{483}$ e (ii) o árbitro ser um juiz aposentado que tenha um envolvimento significativo com o caso que envolva uma das partes, nos três anos anteriores ${ }^{484}$.

Tratando-se do conhecimento prévio do árbitro a respeito da mesma causa que vai decidir, pelo exame de documentos ou a discussão de estratégias com a parte ou seu advogado, a aparência de parcialidade é incontornável. Por outro lado, tratando-se de decisão pretérita do árbitro sobre questões de fato ou de direito distintas (derivadas de relação de direito material e de litígio não relacionado), mas análogas àquelas que serão discutidas no novo procedimento, não resta caracterizada a aparência de parcialidade.

Tratando-se de contato prévio do árbitro com litígio diferente daquele que informará o processo arbitral, deverão ser ponderadas as particularidades de cada caso à luz do que comumente acontece, aferindo-se a proporcionalidade da identificação do evento ou situação com a aparência de parcialidade e das respectivas consequências jurídicas de acordo com os seguintes critérios:

- ligação entre as disputas, que deve ser analisada sob a ótica do direito material (isto é, derivarem de uma mesma relação jurídica material ou de relações conexas) e, quando já existente processo anterior, também sob a ótica do direito processual (isto é, ser o processo arbitral antecedente, decorrente ou de qualquer forma derivado do processo anterior). De fato, mais aparente é a parcialidade de um árbitro que foi profissional que analisou a documentação para ajuizamento de ação cautelar preparatória (processo antecedente) para conservação dos direitos contratuais que serão discutidos no processo arbitral (mesma relação jurídica material), do que a de um árbitro que analisou a relação entre subcontratados não vinculados ao contrato originalmente em discussão (relação jurídica material diferente) em processo distinto (processo arbitral não derivado do processo anterior); ou

\footnotetext{
${ }^{483}$ Seção 3.1.5.

${ }^{484}$ Seção 3.4.4.
} 
- conhecimento anterior do árbitro a respeito de provas que serão utilizadas para a comprovação de alegações das partes no processo arbitral. De fato, mais aparente a parcialidade do árbitro que analisou, previamente ao processo arbitral, o contrato sobre o qual deverá decidir, do que a do árbitro que apenas leu em jornal notícia sobre a assinatura ou sobre disputa a respeito desse mesmo contrato.

\subsubsection{Categoria (3.2) - Posições técnicas defendidas pelo árbitro}

A alegação de parcialidade do árbitro por conta de posições tomadas em estudos acadêmicos, publicações técnicas ou exposições orais não é nova. No caso ICSID Saipem v. Bangladesh ${ }^{485}$, o Estado impugnou o árbitro por esse motivo (entre outros), apontando que o estudo publicado pelo árbitro demonstraria preconcepção frente a temas centrais do processo arbitral. Os demais árbitros não deram provimento à impugnação, entendendo que opiniões doutrinárias dadas em abstrato e sem referência a qualquer caso específico não afetam a imparcialidade ou independência do árbitro.

No caso ICSID Tanesco $v$. IPTL ${ }^{486}$, a requerente impugnou o árbitro que ela própria nomeara porque seu auxiliar havia publicado dois artigos no blog da Kluwer Law, os quais, embora aparentassem tratar de casos hipotéticos, continham detalhada discussão dos fatos e questões do processo arbitral. Mais que isso, o nome hipotético atribuído à Tanesco nos artigos foi "NoPay G\&E", ao Estado da Tanzânia foi "Nopayland", e o habitantes do país foram chamados de "Nopaylandese". A referência à parte e as conclusões tomadas nos artigos demonstrariam, segundo a Tanesco, prejulgamento, especialmente porque não eram conhecidas as circunstâncias em que os artigos foram escritos e a relação entre o seu autor e o árbitro, informações que foram requeridas à Secretaria da ICSID e ao árbitro. O árbitro confirmou que o autor dos artigos o estava auxiliando na arbitragem, que referido autor solicitou sua permissão para publicá-los e que ele, árbitro, havia revisto e aprovado os artigos, mas não trabalhado neles. A revisão e aprovação haviam sido feitas, segundo o árbitro, apenas com o intuito de assegurar que os artigos continuassem hipotéticos e não

\footnotetext{
${ }^{485}$ Caso referido por KAREL DAELE. Challenge... op. cit., p. 398.

${ }^{486}$ Caso referido por KAREL DAELE. Challenge... op. cit., pp. 388-399.
} 
fossem ligados à arbitragem em curso. Tanesco impugnou o árbitro com base na revisão e aprovação do artigo, e os coárbitros proferiram decisões divergentes, remetendo o caso ao Presidente do Conselho Administrativo do ICSID. Dois dias antes de a decisão ser proferida, o árbitro renunciou ao encargo.

Processo arbitral instaurado consoante o Capítulo 11 do NAFTA, Canfor v. United States $^{487}$, tratou do posicionamento pretérito do árbitro. O litígio envolvia decisão do US Department of Commerce e da US International Trade Commission, que resultou no aumento das obrigações relativas à importação de madeira do Canadá. Canfor nomeou árbitro que revelou que, um ano antes, havia feito exposição a um conselho do governo do Canadá, no qual havia comentado o entendimento da US Internal Trade Commission, segundo o qual a indústria madeireira norte-americana estava sendo prejudicada pelas importações oriundas do Canadá. Na sua exposição, o árbitro havia comentado que aquela seria a quarta vez que o Canadá era acusado pelos Estados Unidos e que em todas as outras vezes o Canadá havia vencido a disputa, mas que, no entanto, os Estados Unidos continuavam a criar embaraços e litígios frente ao Canadá. Os Estados Unidos impugnaram a nomeação, sob a alegação de que os comentários do árbitro nomeado refletiam o prejulgamento de que as medidas que seriam discutidas na arbitragem violariam o NAFTA. Três meses após a impugnação, o Secretário Geral do ICSID, atuando como autoridade indicada para a decisão, informou ao árbitro que seria dado provimento à impugnação caso este não renunciasse. $\mathrm{O}$ árbitro renunciou.

As IBA Guidelines se referem às opiniões técnicas do árbitro em duas listas. Na Lista Laranja há referência à hipótese de o árbitro ter advogado publicamente sobre posição em um caso que está sendo arbitrado, seja em publicação, oralmente ou por qualquer outro meio ${ }^{488}$. Na Lista Verde consta a hipótese de o árbitro ter publicado uma opinião geral sobre um assunto que também seja discutido em um processo arbitral, mas que não tenha foco em caso discutido por arbitragem ${ }^{489}$.

\footnotetext{
${ }^{487}$ Caso referido por KAREL DAELE. Challenge... op. cit., pp. 403-404.

${ }^{488}$ Seção 3.5.2.

${ }^{489}$ Seção 4.1.1.
} 
Considerados os casos analisados, é possível afirmar que a aparência de parcialidade gira em torno de um único critério: a manifestação do árbitro a respeito de fatos ou a apresentação de considerações relativas ao específico conflito que irá decidir. Difícil senão impossível - afirmar que a aparência de parcialidade possa ser atribuída a estudo ou posição teórica defendida pelo árbitro ${ }^{490}$, pois inúmeros podem ser os fatores ou cincunstâncias de fato ou de direito que afastem a aplicação de tal posição teórica no caso concreto.

\subsubsection{Categoria (3.3)-Duplo papel do árbitro}

Tal como visto, salvo algumas exceções, o papel de árbitro é geralmente um entre outros desenvolvidos pelos profissionais atuantes nesse mercado ${ }^{491}$. Árbitros que compõem um painel podem ser - e geralmente são - advogados ou peritos perante outros, em prática que abre espaço para uma peculiar situação que pode, em casos especiais, ensejar a aparência de parcialidade. Isso porque, mesmo atuando perante litígios e partes distintas, o árbitro pode ser convocado a decidir sobre teses ou alegações de fato e de direito muitíssimo próximas àquelas que, na função de advogado, lhes são dadas defender ou atacar. Assim, entende-se que o profissional, como julgador, pode ser influenciado, ainda que de modo inconsciente, pelo quanto ele próprio defende no papel de advogado.

Conhecido é o caso UNCITRAL Telekom Malaysia v. Ghana, no qual o Estado impugnou o árbitro nomeado pelo investidor, Emmanuel Gaillard, no curso do procedimento arbitral, sem sucesso, sob a alegação de que ele estava, paralelamente, patrocinando procedimento de anulação de uma sentença proferida em processo arbitral ICSID no qual Gana se amparava para sustentar sua defesa. Levada a questão ao Poder Judiciário holandês (por ser a Haia a sede do procedimento arbitral), restou aplicado o art. 1033 do diploma processual civil holandês, o qual estabelece o afastamento do árbitro se houver dúvida justificada

\footnotetext{
${ }^{490}$ Conforme o lúcido aviso: "It would be a shame to exclude from service those who really know something, leaving arbitration only to the ignorant." WILLIAM W. PARK. Arbitrator integrity... op. cit., p. 644.

${ }^{491}$ Essa pode ser uma realidade em processo de mudança. De fato, é possível perceber que alguns profissionais estão canalizando esforços no sentido de atuarem apenas como árbitro, tal como demonstra o folder do $8^{\circ}$ Congresso Latinoamericano de Arbitraje, de 28 de abril a $1^{\circ}$ de maio, no Peru, que conta com o patrocínio de profissionais (pessoas físicas) que se identificam como árbitros. Documento disponível no endereço eletrônico http://peruvianarbitration.org/2014/sponsors-plata/nacional-2/; consulta em 21.02.2014.
} 
sobre a sua imparcialidade, entendendo a Corte Distrital da Haia que, na função de advogado, Gaillard deveria se utilizar de todos os argumentos necessários contra a sentença ICSID que buscava anular, atitude incompatível com a postura de julgador, que deveria ser aberta e não enviesada no exame do caso. Assim, diante do conflito de interesses derivado do duplo papel ostentado pelo profissional (árbitro e advogado), a Corte Distrital concedeu-lhe dez dias para que ele decidisse se renunciaria ao papel de advogado, mantendo-se como árbitro, o que acabou ocorrendo ${ }^{492}$. Gana não se contentou com a decisão e apresentou novo pedido de afastamento do árbitro, sob a alegação de que a participação do árbitro nas ordens processuais anteriores à sua renúncia como advogado já demonstrariam seu entendimento contrário aos argumentos do Estado. A impugnação foi improvida, sob o entendimento de que os profissionais desempenham tanto o papel de árbitro como de advogados nas arbitragens internacionais, e isso torna comum que o árbitro tenha que decidir questão sobre a qual ele tenha, previamente, defendido um ponto de vista e que, salvo em circunstâncias excepcionais, não há razão para sustentar que o árbitro decidiria a questão com menos tendenciosidade nessa hipótese do que se jamais tivesse se posicionado sobre ela ${ }^{493}$.

No caso Glamis Gold v. The United States, procedimento arbitral conforme o Capítulo 11 do NAFTA, processado segundo as regras UNCITRAL, os Estados Unidos impugnaram o árbitro indicado pela Glamis (Donald L. Morgan) por ele, ao tempo da arbitragem, estar representando um cliente em recurso administrativo perante o Departamento do Interior dos Estados Unidos, relativamente a decisões que atingiam os direitos de mineração do particular. O árbitro, portanto, movia como advogado um procedimento que envolvia os interesses e direitos equivalentes aos discutidos no procedimento no qual figurava como árbitro. Mais: fazia-o contra uma das partes da arbitragem. A despeito da recusa inicial em se afastar, o árbitro renunciou ao encargo ${ }^{494}$.

\footnotetext{
492 Impugnação $\mathrm{n}^{\mathbf{0}}$ 13/2004. Decisão disponível no endereço eletrônico http://arbitration.org/sites/default/files/awards/arbr-2004-290-1.pdf; consulta em 21.02.2014.

493 Impugnação $\mathrm{n}^{\mathrm{o}}$ 17/2004. Decisão disponível no endereço eletrônico http://italaw.com/sites/default/files/case-documents/ita0922.pdf; consulta em 21.02.2014.

${ }^{494}$ Informação sobre a renúncia obtida nas pp. 91-92 da sentença; em especial, na nota de rodapé $\mathrm{n}^{\circ} 548$. Disponível no endereço eletrônico http://www.state.gov/documents/organization/125798.pdf; consulta em 21.02.2014.
} 
Às vezes, mais que uma matéria comum, a atividade do árbitro como advogado em outro caso envolve também uma das partes do procedimento arbitral. Foi o que ocorreu no caso Grand River v. US, procedimento arbitral conforme o tratado NAFTA, perante o ICSID e segundo as regras UNCITRAL, no qual os Estados Unidos impugnaram, com fundamento nas IBA Guidelines, o árbitro James Anaya, que revelou supervisionar a elaboração de diversos trabalhos e informes relativos aos direitos humanos e liberdades dos povos indígenas, bem como representar e assistir à representação de alguns desses povos em questões levadas à Comissão Interamericana de Direitos Humanos e ao Comitê de Direitos Humanos Sobre a Eliminação da Discriminação Racial da Organização das Nações Unidas contra atos governamentais, em especial da esfera federal dos Estados Unidos ${ }^{495}$. O Secretário-Geral do ICSID solicitou ao árbitro a informação se este continuaria a atuar como advogado antes de anunciar a sua decisão. Como Anaya informou que estava em processo de renúncia e interrupção de sua participação nos casos, mantendo apenas a orientação de estudantes como parte prática da sua atividade docente, o Secretário-Geral do ICSID julgou improvida a impugnação ${ }^{496}$.

É registrado caso CCI em que os requeridos (Estado e entidade estatal) impugnaram profissional que havia sido indicado como coárbitro porque ele estava atuando - em casos ainda em curso - contra eles. As partes defendidas pelo árbitro nesses outros casos atuavam no mesmo ramo de negócios que o requerente e a entidade estatal no processo para o qual foi nomeado. A CCI deu provimento à impugnação e afastou o árbitro ${ }^{497}$.

Houve caso em que não se tratou propriamente de um conflito cognitivo entre os papéis de árbitro e de advogado desenvolvidos pelo mesmo profissional, alegando-se que esse duplo papel ensejaria uma troca de favores. Trata-se do caso $S G S$ v. Pakistan ${ }^{498}$, no qual o investidor impugnou o árbitro indicado pelo Paquistão (J. Christopher Thomas) porque ele,

\footnotetext{
${ }^{495}$ Caso Grand River Enterprises, Six Nations Ltd. et al v. the United States of America, Respondent's first submission challenging arbitrator Anaya; disponível no endereço eletrônico http://www.naftalaw.org/Disputes/USA/GrandRiver/GRE-USA-Anaya_Challenge-25-04-07.pdf; consulta em 21.02.2014.

${ }^{496}$ Soliticação disponível no endereço eletrônico http://www.naftalaw.org/Disputes/USA/GrandRiver/GREUSA-Anaya Challenge-28-11-07.pdf; consulta em 21.02.2014.

${ }^{497}$ ANNE MARIE WhiteSELL. Independence... op. cit., p. 30.

${ }^{498}$ Caso SGS Société Générale de Surveillance S.A. v. Islamic Republic of Pakistan (ICSID Case No. ARB/01/13), referido por Karel Daele. Challenge... op. cit., pp. 291-292 e por SAMUEL Ross LutTRell. Bias... op. cit., pp. 228-229.
} 
na qualidade de advogado em uma arbitragem não relacionada, havia obtido, três anos antes, uma sentença muito favorável de um tribunal que havia sido presidido por um dos advogados do Paquistão na arbitragem em curso, Jan Paulsson. O modo pelo qual o cliente de Thomas havia sido tratado poderia indicar, segundo a SGS, que o profissional agora retornaria o favor. Ademais, a indicação de Paulsson para outro painel ICSID no qual o escritório de advocacia de Thomas representava uma das partes reforçava a aparência de tendenciosidade e as dúvidas justificadas sobre a imparcialidade do árbitro. Os demais árbitros, ao decidirem a impugnação, apontaram que "[t]he party challenging an arbitrator must establish facts, of a kind or character as reasonably to give rise to the inference that the person challenged clearly may not be relied upon to exercise independent judgment in the particular case where the challenge is made", e que uma simples suposição ou especulação não é suficiente para caracterizar, clara e objetivamente, a parcialidade do árbitro. Além disso, em relevante apontamento sobre a imparcialidade em comunidades arbitrais pequenas, os árbitros apontaram "[i]t is commonplace knowledge that in the universe of international commercial arbitration, the community of active arbitrators and the community of active litigators are both small and that, not infrequently, the two communities may overlap, sequentially if not simultaneously. It is widely accepted that such an overlap is not, by itself, sufficient ground for disqualifying an arbitrator. Something more must be shown if a challenge is to succeed. In the instant case, that 'something more' has not been shown by the Claimant." 499

A análise dos casos que compõem a categoria demonstra a necessidade de se ponderar as particularidades de cada um, aferindo-se a proporcionalidade da identificação do evento ou situação com a aparência de parcialidade e das respectivas consequências jurídicas de acordo com os seguintes critérios:

- semelhança entre a questão que o árbitro deve resolver com aquela sobre a qual, como advogado, deve tratar sob um ponto de vista, de modo que essa tomada de posição seja determinante para o acatamento ou afastamento de alegação produzida no processo arbitral no qual o árbitro deve decidir; e

${ }^{499}$ Trechos transcritos por KAREL DAELE. Challenge... op. cit., pp. 291-292. 
- contemporaneidade do papel de árbitro e de advogado, afastando-se a aparência de parcialidade se o árbitro não estiver mais defendendo (por ter renunciado à função de advogado ou pelo fim da disputa) uma posição sobre a questão.

\subsubsection{Categoria (3.4) - Nomeações repetidas do árbitro}

A prática mais comum de composição dos tribunais arbitrais é a nomeação, pelas partes, de coárbitros, podendo estes últimos ou a instituição arbitral indicar o árbitro presidente. Assim, as partes tendem a escolher como julgadores aqueles que lhes parecerem reunir as melhores qualidades para a decisão do conflito, com a máxima possibilidade de que essa decisão seja proferida a seu favor. Essa busca pelo melhor árbitro ou pelo árbitro mais adequado para o litígio pode ensejar a oportunidade de que litigantes frequentes direcionem nomeações, em processoas arbitrais distintos, aos mesmos profissionais. Não se trata, aqui, de relação negocial, social ou institucional pretérita entre parte e árbitro; ao menos não relação independente e não derivada da nomeação do julgador, como árbitro, pela mesma parte, em outros processos arbitrais.

Essa nomeação repetitiva frequentemente traz considerações sobre (i) o incentivo econômico para o árbitro julgar favoravelmente à parte (ou advogado) que, reiteradamente contrata seus serviços e (ii) o número de nomeações que estabeleceria um efetivo relacionamento entre árbitro e parte que ultrapassasse o limite do tolerável e passasse a ensejar a aparência de parcialidade ${ }^{500}$.

A jurisprudência francesa registra casos em que esses questionamentos foram feitos, o que ensejaria, nos casos de nomeação repetitiva além do tolerável, a existência de courant d'affaires entre árbitro e parte ou árbitro e advogado. Além dos casos Tecso v. Neoelectra Group $^{501}$ e Somoclest v. DV Construction ${ }^{502}$, a França também registra o caso Frémarc v.

\footnotetext{
${ }^{500}$ NATALIA GIRALDO-CARRILlO. The 'repeat arbitrators' issue: a subjective concept, in Revista colombiana de derecho internacional, 2011, pp. 87-91.

${ }^{501}$ Para mais detalhes, vide p. 40 do presente estudo.

${ }^{502}$ Para mais detalhes, vide p. 38 do presente estudo.
} 
ITM Entreprises $^{503}$, no qual o requerido, um franqueador, havia nomeado o mesmo árbitro para diversos procedimentos em que litigou com distintos franqueados. $\mathrm{O}$ árbitro não revelou essa circunstância, levando a Corte de Cassação a anular a decisão da Corte de Apelação (a qual havia considerado que o tribunal tinha sido validamente constituído) e considerar que o árbitro não havia se desincumbido do seu dever de revelação ${ }^{504}$.

No caso Neaman v. Kaiser Foundation, a Corte de Apelação da Califórnia anulou sentença proferida em processo arbitral conforme o FAA porque o árbitro neutro, Ralph Drummond, não havia revelado que, após se aposentar da judicatura, passou cerca de trinta por cento de seu tempo com árbitro em casos que envolviam a Kaiser, sendo que, desse total, sessenta e cinco por cento do tempo foi despendido como árbitro nomeado por outros que não a Kaiser, trinta por cento como árbitro neutro e cinco por cento (cerca de cinco casos) como árbitro nomeado pela Kaiser, situação que apenas foi conhecida pela Neaman após a conclusão do processo arbitral. A Corte de Apelação considerou que "Drummond's prior experience as a party arbitrator for Kaiser might create an impression of possible bias", razão pela qual anulou a sentença ${ }^{505}$.

Em mercados mais especializados, tais como os concernentes à lei marítima, comércio de commodities ou arbitragem esportiva - onde o número de profissionais elegível é menor é mais comum e aceita a nomeação mais frequente dos mesmos profissionais para o encargo de árbitro ${ }^{506}$.

\footnotetext{
${ }^{503}$ Caso Frémarc v. ITM Enterprises. Cour de Cassation, decisão de 0612.2001, in Revue de l'arbitrage, n. 4, 2003, pp.1231-1233.

${ }^{504}$ De fato, a decisão não se pautou na nomeação repetitiva do árbitro, mas sim considerou a falta de revelação como causa per se de anulação da nomeação do árbitro, em entendimento que o presente estudo considera equivocado.

${ }^{505}$ Caso Neaman v. Kaiser Foundation Hospital (1992) 9 Cal. App. 4th 1170 [11 Cal. Rptr. 2d 879]. Decisão disponível no endereço eletrônico http://law.justia.com/cases/california/caapp4th/9/1170.html; consulta em consulta em 21.02.2014.

${ }^{506}$ HOUCHIH KUO. The issue of repeat arbitrators: is it a problem and how should the arbitration institutions respond?, in Contemporary Asia arbitration journal, n. 4, 2011, p. 253. Também as IBA Guidelines reconhecem, na nota de rodapé $\mathrm{n}^{0}$ 6, que "[p]ode ser prática corrente em algumas espécies de arbitragem, tais como aquelas envolvendo commodities ou o setor marítimo, selecionar os árbitros a partir de um grupo restrito e especializado. Se, nessas áreas, o costume for o de as partes geralmente nomearem o mesmo árbitro para controvérsias distintas, a divulgação de tal fato não será necessária desde que todas as partes no procedimento arbitral estejam familiarizadas com tais usos e costumes".
} 
Dada a importante participação do advogado ou do seu escritório na condução da arbitragem, a nomeação repetitiva se estende ao comportamento destes ${ }^{507}$. Foi o que ocorreu no caso ICSID, OPIC Karimum v. Venezuela ${ }^{508}$, em que o tema foi discutido. O requerente impugnou o árbitro nomeado pela Venezuela, Philippe Sands, diante do fato de ele ter sido nomeado cinco vezes em processos arbitrais ICSID nos últimos três anos, em processos arbitrais que envolviam a Venezuela ou o escritório que a patrocinava no procedimento arbitral em questão (Curtis Mallet-Prevost, Colt \& Mosle LLP), o que ensejaria uma proximidade de conexão, intensidade e frequência de interações e grau de dependência material ou significativa, caracterizado pelo incentivo em continuar a proferir decisões favoráveis aos clientes do escritório que o nomeava e assim ser selecionado para futuras arbitragens. Os árbitros responsáveis pelo julgamento da impugnação consideraram que múltiplas nomeações "may lead to the conclusion that it is manifest that the arbitrator cannot be relied upon to exercise independent judgment". No entanto, considerando o critério econômico, pelo qual "it is clear that Professor Sands has extensive independent sources of income unrelated to the fees derived from his appointments as arbitrator", a impugnação foi afastada.

Raciocínio análogo foi formulado no caso Tidewater $v$. Venezuela, no qual a árbitra indicada pelo Estado, Brigitte Stern, foi impugnada com base na Seção 3.1.3 das IBA Guidelines por ter sido indicada pela Venezuela em quatro procedimentos ICSID pretéritos, sendo que em três deles o Estado era representado pelo mesmo escritório e, no quarto caso, pelo mesmo escritório que representava a Venezuela na arbitragem corrente, o que também autorizaria a impugnação com base na Seção 3.3.7 das IBA Guidelines. No curso do procedimento de impugnação, o investidor apresentou outro fundamento: o fato de que uma das arbitragens ICSID anteriores continha questão idêntica à levantada na arbitragem em questão, a saber, se a lei de investimento venezuelana expressaria o consentimento do Estado em se submeter a arbitragens ICSID. Outro fundamento para impugnação, ligado a não revelação das arbitragens anteriores pela árbitra, não vem ao caso. Os árbitros encarregados da decisão consideraram que, em princípio, nomeações repetidas pela mesma parte, em conflitos não relacionados, são neutras, pois “[r]epeat

\footnotetext{
${ }^{507}$ FATIMA-ZAHRA SLAOUI. The rising issue of 'repeat arbitrators': a call for clarification, in Arbitration international, v. 25, n. 1, 2009, p. 109.

${ }^{508}$ Caso OPIC Karimum Corporation v. Bolivarian Republic of Venezuela (ICSID Case No. ARB/10/14). Decision on the proposal to disqualify Prof. Philippe Sands, arbitrator, disponível no endereço eletrônico http://italaw.com/documents/OPICKarimumDisqualificationDecision.pdf; consulta em 21.02.2014.
} 
appointments may be as much the result of the arbitrator's independence and impartiality as an indication of justifiable doubts about it" ${ }^{509}$. O que não pode ocorrer é a nomeação continuada e regular, que enseje relação de benefício econômica ou análoga. Mas, no caso em questão, as nomeações pretéritas da árbitra não dariam fundamento ao afastamento, pois em duas delas a árbitra havia dado decisões conjuntas nas quais foram rejeitadas alegações da Venezuela, o que indicaria a independência da árbitra.

A aparência de parcialidade pode surgir não apenas por nomeações feitas pela mesma parte, mas também por sociedades diferentes pertencentes a um mesmo grupo econômico. A SCC já decidiu caso em que o árbitro informou ter sido, no período de dois anos, nomeado oito vezes pela parte e seis vezes por sociedades que pertenciam ao mesmo grupo. Mesmo diante da negativa de existência de relação com o árbitro, feita pela parte, a SCC deu provimento à impugnação, comentando a doutrina que isso fora feito para deixar a impressão de que a instituição mantinha altos padrões éticos ${ }^{510}$.

Em caso CCI, o árbitro nomeado pelo requerido apresentou inicialmente declaração de independência, sem revelar qualquer informação importante. Após discussões com a Secretaria, o julgador apresentou nova declaração, desta vez fazendo constar que ele estava servindo como presidente do tribunal arbitral no qual o advogado do requerido funcionava como coárbitro. Todavia, o árbitro presidente não revelou que havia sido nomeado pelo mesmo advogado (e coárbitro no outro processo arbitral) em outros três processos arbitrais CCI no interregno de seis meses. O requerente se opôs à confirmação do árbitro, que não ocorreu $^{511}$.

Em outro caso CCI, o árbitro nomeado pelo requerente informou que também atuava em outro processo arbitral não diretamente ligado, cujo proponente era sociedade integralmente detida pelo requerente. Informou que os dois processos arbitrais envolviam partes do mesmo país, que o tema da disputa era do mesmo tipo e que os requerentes em ambos eram representados pelo mesmo advogado. Havia risco de que o árbitro tivesse

\footnotetext{
${ }^{509}$ Caso Tidewater Inc. v. The Bolivarian Republic of Venezuela (ICSID Case No ARB/10/5). Decision on claimants' proposal to disqualify Professor Brigitte Stern, arbitrator, disponível no endereço eletrônico http://italaw.com/sites/default/files/case-documents/ita0860.pdf; consulta em 21.02.2014.

${ }^{510}$ FATIMA-ZAHRA SALOUI. The rising... op . cit., p. 111.

${ }^{511}$ ANNE MARIE WHITESELL. Independence... op. cit., p. 23
} 
acesso à informação não disponível aos demais membros do tribunal arbitral. O requerente (que não estava participando ativamente da arbitragem) não apresentou objeção à confirmação, o que não impediu a CCI de não confirmar a nomeação ${ }^{512}$.

As IBA Guidelines abordam a categoria ora tratada na Lista Laranja, considerando as hipóteses em que o árbitro: $(i)$ foi nomeado, nos três anos anteriores, para exercer a mesma função em duas ou mais ocasiões, por uma das partes ou por coligada ${ }^{513}$; (ii) atua ao tempo do processo arbitral, ou atuou nos três anos anteriores, como árbitro em outro processo arbitral em assunto relacionado que envolve uma das partes ou sua coligada ${ }^{514}$; e (ii) foi o destinatário, nos três últimos anos, de mais de três nomeações pelo mesmo consultor jurídico ou pelo mesmo escritório de advocacia ${ }^{515}$.

A análise dos casos concretos demonstram que a aparência de parcialidade está geralmente ligada aos seguintes critérios:

- histórico de nomeações do árbitro pela parte ou pelo advogado (ou seu escritório) em um dado intervalo de tempo;

- proximidade, no tempo, dessas nomeações em relação ao processo arbitral em curso;

- representatividade econômica da remuneração total obtida pelo árbitro nos casos em que foi nomeado; e

- se houver, a existência de decisões favoráveis à parte ou ao advogado que recorrentemente o nomeou.

\footnotetext{
${ }^{512}$ ANNE MARIE WHITESELL. Independence... op. cit., p. 22.

${ }^{513}$ Seção 3.1.3.

${ }^{514}$ Seção 3.1.5.

${ }^{515}$ Seção 3.3.7.
} 


\subsubsection{Categoria (3.5) - Atuação do árbitro no processo}

A aparência de parcialidade pode derivar de atitudes tomadas pelo árbitro no curso do procedimento. Por vezes, o árbitro procede a atos que demonstram sua franca predisposição a uma das partes, seja mantendo com uma delas comunicação indevida sobre a disputa, seja proferindo decisão que favorece uma das partes frente à outra. A categoria proposta pelo presente estudo também compreende as opiniões que eventualmente o árbitro venha a emitir no curso do processo arbitral, seja substancialmente sobre uma das partes (ou sobre sua atuação no processo) ou sobre o mérito do litígio, que possa ser um indicativo de sua impermeabilidade aos argumentos apresentados pela outra parte.

Não se pode esquecer que os usos de determinada comunidade arbitral, quando respaldados pelas regras aplicáveis, podem ser determinantes para a fixação do alcance das comunicações unilaterais entre as partes e o árbitro, tal como ocorre nas arbitragens internas norte-americanas em que tais comunicações são facultadas aos "non-neutrals",

Em caso CCI, o requerido impugnou o presidente do tribunal arbitral por ele ter expedido ordem processual na qual estabeleceu que novos pedidos do requerente seriam admitidos, antes que o requerido tivesse a oportunidade de apresentar sua resposta à solicitação de admissão desses mesmos pedidos. O requerido alegou que, ao assim decidir, o presidente havia criado uma situação mais favorável ao requerente, evidenciando a falta de independência. Além disso, o requerido alegou que a decisão violava o devido processo, pois também concedia a ele prazo menor para responder aos novos pedidos do que para o requerente responder à reconvenção. Após tomar ciência da impugnação, o presidente do tribunal retificou a ordem processual. A Corte rejeitou a impugnação ${ }^{517}$.

Em arbitragem LCIA, os requerentes apresentaram pedido de desqualificação do árbitro presidente nomeado pela instituição, entre outros motivos, por este: $(i)$ ter mencionado o processo arbitral e o nome das partes em seu curriculum, em violação às regras regulamentares de confidencialidade; (ii) ter emitido ordens processuais contra os requerentes; e (iii) ter utilizado linguagem imprópria ao se referir ao advogado dos

\footnotetext{
${ }^{516}$ Vide caso Sunkist, referido na nota de rodapé no 312.

${ }^{517}$ JASON FRY; SIMON GREENBERG. The arbitral tribunal: applications of articles 7-12 of the ICC Rules in recent cases in ICC Court of Arbitration bulletin, v. 20, n. 2, 2009, p. 24.
} 
requerentes em email enviado aos membros do tribunal, aos advogados das partes e à LCIA, no qual afirmava que o advogado dos requerentes "gets his pleasure in abusing us" e "I do not like his floating threats". Na decisão do pedido, a divisão da LCIA considerou que a incorporação de informações confidenciais no curriculum derivaria mais de desatenção do árbitro do que de deliberada violação das obrigações impostas pelo regulamento da LCIA. Quanto ao segundo ponto, a divisão considerou que as ordens processuais foram proferidas por todo o tribunal, não se podendo atribuir ao árbitro a responsabilidade exclusiva pelas decisões, nem considerá-las enviesadas contra os requerentes apenas porque elas não os favoreciam. Quanto ao terceiro tema - o mais delicado dos três - o email era destinado apenas aos coárbitros, mas inadvertidamente foi enviado a todos, razão pela qual foi considerado "unfortunate", demonstrativo de " $a$ growing degree of impatience with claimants' counsel', mas não suficiente para justificar o afastamento do árbitro ${ }^{518}$.

Considerações mais enfáticas sobre o comportamento processual de um litigante já foram consideradas suficientes pela LCIA para a impugnação de árbitro. No caso, o requerente impugnou o árbitro único em razão de ele ser membro de uma organização profissional supostamente ligada ao requerido. Em resposta, o árbitro qualificou a impugnação como "fictitious, false and malevolent" e afirmou que o advogado do requerente estava agindo "viciously". A divisão da LCIA considerou que a impugnação, nas suas bases originais, deveria ser rejeitada, mas que a reação do árbitro a tal impugnação era suficiente para o seu afastamento $^{519}$.

No caso LCIA National Grid v. Argentina, esta requereu a remoção do árbitro Judd Kessler por conta de colocação feita verbalmente por ele sobre a resposta da testemunha técnica ao cross-examination do advogado da Argentina, a saber, "[p]ara tratar de avanzar, ya queda claro que hay ciertos hechos que el testigo no conoce. Pero supongo que la base de su testimonio tiene que ver con la situatión hipotética, y no es hipotética porque todos los que estamos aqui sabemos los hechos en general, de que hubo un daño

\footnotetext{
${ }^{518}$ Caso LCIA Reference No. 5665; decisão de 30.08.2006, referida por KAREL DAELE. Challenge... op. cit., pp. 415-416.

${ }^{519}$ Caso LCIA Reference No. 1303; decisão de 22.10.2001, referido por KAREL DAELE. Challenge ... op. cit., p. 420.
} 
importante o hubo un cambio muy importante en las expectativas de la inversion" Segundo o Estado, a afirmação do árbitro - cuja língua nativa não era o espanhol revelaria prejulgamento, pois ambas as partes ainda tinham argumentos e provas sobre a alegação de que a expectativa do investidor havia sido alterada ou que ele havia sofrido um dano. O órgão da LCIA responsável pela decisão do pedido de remoção considerou, primeiramente, que a afirmação do árbitro, tomada fora de contexto, poderia sugerir a um terceiro razoável que o árbitro já havia tomado uma posição firme sobre questões vitais para a arbitragem. No entanto, analisando o contexto da transcrição, ficava claro que o árbitro estava apenas colocando uma questão hipotética à testemunha técnica, justamente para clarificar a questão colocada pelo advogado da Argentina, ao esclarecer que " $[n] o$ sé si podemos proceder. Si quiere hacerle preguntas, si hubiera un daño importante, entonces, ¿qué sería el resultado bajo el derecho argentino? Hay protección o no hay proteción. La ley aplica o no aplica. Es solamente una sugerencia". Diante da tentativa de esclarecimento da pergunta, o advogado da Argentina prontamente questionou se o árbitro havia sugerido que ele já estaria convencido da existência do dano, ao que este respondeu "[s]olamente digo que estamos aquí porque hay alegato de daño, de um cambio en el contrato que resultó en problemas por el investor. Es que, como decíamos antes, no estamos hablando en el aire. No sé, estoy tratando de ayudar, pero a lo mejor no resulta de ayuda". Assim, a dúvida a respeito da primeira intervenção do árbitro - que poderia ser agravada pelo fato de ele não ter se expressado na sua língua materna - foi eliminada quando ele, posteriormente, clarificou a sua posição, o que, segundo a divisão competente da LCIA, não configuraria prejulgamento, razão pela qual o pedido de afastamento foi improvido.

A LCIA também registra caso ${ }^{521}$ em que o árbitro único foi impugnado por ter mantido uma reunião de quinze minutos com o advogado do requerente na sala de apoio que lhe havia sido reservada para a audiência, durante um dos intervalos. A mesma impugnação trazia alegação de que o árbitro havia apagado parte das transcrições da audiência, mesmo com a oposição do advogado do requerido. Por último, a impugnação apontava que o

\footnotetext{
${ }^{520}$ Caso National Grid PLC v. The Republic of Argentina, LCIA Case No. 7949. Decision on the challenge to Mr. Judd L. Kessler; disponível no endereço eletrônico http://www.italaw.com/sites/default/files/casedocuments/italaw1171.pdf; consulta em 21.02.2014.

${ }^{521}$ Caso LCIA Reference No. UN3490; decisão de 21.10.2005, referida por GEOFF NiCHOLAS; CONSTANTINE PARTASIDES. LCIA Court decisions on challenges to arbitrators: a proposal to publish, in Arbitration international, v. 23, n. 1, 2007, pp. 14-16.
} 
árbitro havia acusado o advogado do requerido de ter entrado na sua (do requerido) sala de descanso em duas ocasiões, o que o advogado negou. A divisão da LCIA deu provimento à impugnação, considerando que: (i) a reunião do árbitro com o advogado no intervalo da audiência, a portas fechadas, ensejava suspeita de tratamento desigual das partes; (ii) o árbitro não poderia unilateralmente decidir que certas partes da audiência simplesmente não teriam existido; e (iii) a acusação do árbitro quanto à conduta do advogado do requerido havia levado a uma acalorada discussão entre ambos e que tal conduta não era compatível com o comportamento esperado de um árbitro.

Considerações diretas sobre a índole da parte já deram causa ao afastamento de árbitro no conhecido caso Catalina, que envolvia a colisão de um navio português com um navio norueguês. Uma testemunha da parte portuguesa jurou que, durante a audiência, ouviu o árbitro fazer considerações sobre a índole e a confiabilidade das testemunhas de acordo com a sua nacionalidade, declarando que aceitaria as provas norueguesas e não as portuguesas $^{522}$. Os portugueses requereram a remoção do árbitro ao King's Bench, que acatou o pedido. Há quem considere que, nesses casos, não se está diante da aparência de parcialidade, mas de parcialidade demonstrada ("actual bias") ${ }^{523}$, posição da qual o presente estudo não compartilha, por considerar que se está diante de uma aparência mais fortemente demonstrada - mas ainda aparência, e não certeza, que somente deriva da declaração do árbitro - de parcialidade.

Em caso ICSID, Burlington Resources v. Republic of Ecuador, o árbitro nomeado pelo investidor, Prof. Francisco Vicuña, foi impugnado porque: (i) havia sido nomeado em outras 8 causas ICSID patrocinadas pelo escritório de advocacia que representava o autor (Freshfields Bruckhaus Deringer), entre os anos de 2007 e 2013, o que caracterizaria dependência; (ii) não teria cumprido com o seu dever de revelação, somente tendo informado sobre as repetidas nomeações a pedido do Equador, o que daria causa ao questionamento sobre a confiabilidade de sua independência; (iii) teria demonstrado a falta

\footnotetext{
${ }^{522}$ Caso Re the Owners of the Steamship 'Catalina' and the Owners of the Steamship 'Norma', [1938] 61 Lloyd's Rep 360. Decisão disponível no endereço eletrônico http://translex.unikoeln.de/output.php?docid=311230\&markid=968935; consulta em 21.02.2014. Ao se referir aos noruegueses, o árbitro teria dito que eles "are not Italians. The Italians are all liars in these cases and will say anything to suit their book. The same thing applies to the Portuguese. But the other side are Norwegians, and in my experience the Norwegians generally are truthful people. In this case I accept the evidence of the master of the Norma."

${ }^{523}$ SAMUEL Ross LUTTRELL. Bias... op. cit., p. 44.
} 
de imparcialidade em detrimento do Equador no curso da arbitragem, em razão da sua postura em conferência telefônica e durante audiência, na qual a vasta maioria das questões (colocadas pelo árbitro) teria como finalidade minar a posição do Equador ou favorecer a posição do investidor no processo arbitral, postura essa também demonstrada por seus votos divergentes, proferidos em duas decisões anteriores nesse mesmo procedimento arbitral; e (iv) a própria forma como foram redigidos os esclarecimentos do árbitro, que mencionava conduta do escritório que defendia o Equador (Dechert LLP), demonstraria a sua falta de imparcialidade. $\mathrm{O}$ investidor respondeu, afirmando que: (i) a impugnação contra o árbitro teria como objetivo sabotar o processo arbitral, pois as informações sobre as diversas nomeações do árbitro, utilizadas pelo Equador, eram públicas desde 19.02.2013 (e seis das oito nomeações eram conhecidas pelo Equador desde junho de 2011), ao passo que a impugnação somente foi apresentada em 20.06.2013; (ii) as alegações sobre a conduta do árbitro na conferência telefônica e em audiência estavam preclusas, pois a audiência havia ocorrido dois anos antes e o voto divergente mais recente havia sido proferido mais de seis meses antes da impugnação do árbitro; e (iii) o padrão para o afastamento do árbitro é alto nos processos ICSID, e que a manifesta falta de independência deveria ser estabelecida por provas objetivas - e não em meras suposições ou especulações. O árbitro apresentou suas explicações. Como as demais componentes do tribunal arbitral (Gabrielle Kaufmann-Kohler e Brigitte Stern) não chegaram à decisão unânime sobre a impugnação, o Presidente do Conselho Administrativo proferiu decisão na qual apontou que o Equador tinha à sua disposição informações públicas suficientes para impugnar o árbitro em razão das sucessivas nomeações pelo Freshfields antes do momento em que acabou fazendo, razão pela qual afastou tal fundamento para a impugnação. No entanto, o Presidente do Conselho chamou a atenção ${ }^{524}$ para o seguinte trecho da carta de informações prestadas pelo árbitro, no qual constava: "[l]astly there are some ethical assertions that cannot be left unanswered. Dechert admonishes this arbitrator to resign on ethical grounds as if Dechert's views were proven correct. This is certainly not the case. Moreover, the real ethical question seems to lie with Dechert's submissions and the handling of confidential information. To the best of this arbitrator's knowledge the correspondence concerning disclosure and other matters in Pan American v. Bolivia is part of the confidential record of that case.

\footnotetext{
${ }^{524}$ Caso Burlington Resources, Inc. v. Republic of Ecuador (ICSID Case No ARB/08/5). Decision on the proposal for the disqualification of Professor Francisco Orrego Vicuña, disponível no endereço eletrônico https://icsid.worldbank.org/ICSID/FrontServlet?requestType=CasesRH\&actionVal=showDoc\&docId=DC39 72 En\&caseId=C300; consulta em 21.02.2014.
} 
Dechert is in the knowledge of such correspondence as counsel for Bolivia, but it does not seem appropriate or ethically justified that this information be now used to the advantage of a different client of Dechert, a use that in any event should be consented to by the other party to that case"; tais comentários, afirmou o Presidente do Conselho "do not serve any purpose in addressing the proposal for disqualification or explaining circumstances relevant to the allegations that the arbitrator manifestly lacks independence or impartiality", razão pela qual acatou a impugnação sob esse fundamento, afastando o árbitro.

O que se percebe dos casos mencionados é que a opinião do árbitro ou as suas falhas procedimentais devem ser suficientes para aparentar que ele não estaria aberto às alegações e argumentos trazidos pelas partes, ou seja, que julgará o litígio com base em sentimentos que o impeçam de analisar e sopesar ditos argumentos. Daí porque a opinião deve ser forte, incisiva e drástica, o que a diferencia totalmente de uma sentença parcial ou ordem processual pela qual, amparado nos argumentos e provas, o árbitro defere ou indefere pedido.

\subsubsection{Categoria (3.6) - Particularidades culturais ou cognitivas derivadas da história de vida do árbitro}

O presente estudo defende que não há julgador sem preconceito, pois esse conceito $a$ priori, derivado da experiência de vida do indivíduo, é condicionante do conhecimento e do reconhecimento do mundo. O julgador, necessariamente, parte do seu inalienável ponto de vista ao entrar em contato com a narrativa de um conflito, e o faz à luz de tudo o que vivenciou e experimentou ${ }^{525}$.

É o preconceito que permite o entendimento da narrativa das partes, a sua apropriação e a sua avaliação pelo árbitro. Por essa razão, o presente estudo se afasta da concepção usual de parcialidade como exposição do árbitro a influências outras que não os argumentos expostos pelas partes e defende uma concepção que, reconhecendo que influências outras sempre existem - o indivíduo tem sua história e, por isso, suas preconcepções - identifica a imparcialidade como a abertura do árbitro à influência dos argumentos das partes expostos

\footnotetext{
${ }^{525}$ Para mais detalhes, vide capítulo 2 do presente estudo.
} 
no processo arbitral e, portanto, entende a parcialidade como a vedação do árbitro a essa influência. Este estudo parte da premissa de que reconhecer o árbitro como indivíduo exposto às influências derivadas da sua história é o passo fundamental para a conceituação - e operatividade - da imparcialidade que dele se requer.

Em raros casos, no entanto, a própria história de vida do árbitro ou atitudes que este tomou ensejam a aparência de que ele, enquanto julgador, está fechado à influência dos argumentos das partes. São casos pontuais, em que o preconceito relativamente ao assunto discutido é tão intenso que a aparência de vedação à influência é visível.

Essa influência não restou visível em caso CCI, no qual o requerido impugnou o árbitro presidente ao alegar, entre outros motivos, que ele não seria independente das partes porque residiu por longo tempo no país de domicílio do requerente, apesar de não possuir a respectiva nacionalidade. $\mathrm{O}$ árbitro, segundo o requerido, teria recebido educação, vivido e atuado no país por mais de doze anos, o que ensejaria uma "strong relationship" com o país que afetaria sua independência. A Corte da CCI afastou a impugnação ${ }^{526}$. Em outro caso, o presidente do tribunal arbitral foi impugnado pelo requerente sob a alegação de que não possuía "independence of mind" por ter escrito diversos artigos nos quais expressava opiniões políticas contra o país de nacionalidade do seu (do requerente) acionista, bem como opiniões políticas em favor de um dos requeridos, que era um Estado. Como os artigos não possuíam relação com a controvérsia submetida ao processo arbitral, a Corte da CCI também afastou a impugnação ${ }^{527}$.

Em caso LCIA ${ }^{528}$, no qual litigavam o Kuwait e uma parte ocidental, o árbitro único indicado pela instituição foi impugnado pela segunda por sua filiação cultural a uma das partes. O árbitro era especialista em leis árabes e islâmicas, o que, segundo o requerente, demonstrava "evident, longstanding and deep commitment to Arab studies and Arab culture", que poderia obstar a que o árbitro fosse imparcial. A impugnação foi afastada pela LCIA pela inexistência de qualquer evidência de que a especialidade do árbitro e sua

\footnotetext{
${ }^{526}$ ANNE MARIE WhiteSELL. Independence... op. cit., p. 30. Mais apontamentos sobre a nacionalidade são trazidos no capítulo 3.4.11 do presente estudo.

${ }^{527}$ ANNE MARIE WhiteSELL. Independence... op. cit., p. 31.

${ }^{528}$ Caso LCIA Reference No. 5660; decisão de 05.08.2005, referida por KAREL DAELE. Challenge... op. cit., p. 477.
} 
exposição à cultura ou às leis árabe e islâmica o tornariam enviesado ou mais receptivo às alegações do Kuwait.

A identidade entre o preconceito do árbitro e o objeto da disputa (a ponto de aparentar a vedação à influência) foi reconhecida no caso Haworth v. Superior Court, no qual a Corte de Apelação da Califórnia manteve a decisão de invalidação da sentença arbitral, pela qual se decidiu um processo arbitral no qual se discutia erro médico supostamente cometido por Randal Hawort no curso de uma cirurgia facial estética a qual se submeteu Susan Ossakow. No processo arbitral, médico e paciente nomearam árbitros, sendo que Haworth propôs outros quatro nomes para a presidência do painel, entre eles um juiz aposentado da Corte Superior de Los Angeles, Norman Gordon, ao final aceito pelo advogado de Ossakow. Norman apresentou declaração na qual apenas afirmou que já havia se envolvido em processo com advogados do escritório que representava o médico. Em decisão majoritária, o tribunal entendeu que a paciente não havia provado a intervenção sem o seu consentimento e que a severidade dos sintomas não seria crível, ressaltando que a paciente havia incorrido em cinco cirurgias faciais estéticas e que, consoante o assistente técnico desta, "[o]ne thing probably everyone can agree upon, after five facial surgeries, [Ossakow] could have done without a sixth one". Depois de intimada da sentença majoritária, a paciente descobriu que o árbitro presidente, quando ainda atuava como juiz, havia sido publicamente censurado pela Suprema Corte da Califórnia por fazer comentários sexuais explícitos, opiniões racistas e comentários desmerecedores sobre suas funcionárias (mulheres) e colegas, baseados em seus atributos físicos. A ação anulatória foi julgada procedente pela Corte Superior da Califórnia e a questão, via write of mandate, foi enviada à Corte de Apelação do Estado $^{529}$ que, acatando a alegação da paciente de que a censura ao juiz revelaria sua tendenciosidade contra mulheres em função de seus atributos físicos, considerou que os fatos ensejariam dúvidas justificadas sobre a imparcialidade do árbitro e que deveriam ter sido revelados.

A discussão sobre a relação entre a imparcialidade do árbitro frente à sua experiência de vida e às suas preconcepções foi levada ao extremo no caso Rebmann v. Rohde, no qual a invalidade da sentença foi debatida perante a Corte de Apelação da Califórnia porque um

${ }^{529}$ Caso Randal D. Haworth v. Superior Court of Los Angeles County, 235 P.3d 152 (Cal. 2010). Decisão disponível no endereço eletrônico http://caselaw.findlaw.com/ca-court-of-appeal/1123505.html; consulta em 21.02.2014. 
dos requeridos na arbitragem, Peter Rohde, descobriu por pesquisas na internet que o árbitro, Stephen Haberfeld, nascido em 1994 e criado nos Estados Unidos, era filho de judeus alemães que abandonaram a Alemanha pouco antes da II Guerra Mundial, tendo perdido parentes e propriedades no Holocausto. O árbitro e seus pais eram membros do “1939 Club", uma organização dedicada a evitar a repetição do Holocausto. O pai de Peter Rohde, por sua vez, havia lutado pela Alemanha na II Guerra Mundial, tendo Rohde deixado a Alemanha quando tinha dezoito anos. A mulher de Rohde, que não deu declarações no processo arbitral, informou que seu pai havia pertencido à SS. Rohde declarou que "[h]ad I known about his religious affiliation, his cultural affiliation, and the dedication to keeping the memory of the Holocaust alive, I never would have allowed him to be the arbitrator in my case." A Corte de Apelação da Califórnia ${ }^{530}$ entendeu, aplicando jurisprudência relativa à imparcialidade dos juízes, que tal como todos os seres humanos, os julgadores têm uma ampla variedade de experiências e backgrounds e, salvo talvez em excepcionais circunstâncias, aquelas não relacionadas com o caso ou com as partes não são suficientes para sua desqualificação. O processo arbitral envolvia questão comercial, não tinha qualquer relação com a II Guerra Mundial ou com o Holocausto, e nenhum fato foi apresentado que pudesse sugerir que o árbitro não fosse imparcial ou que ele tivesse o dever de revelar sua história pessoal ou afiliação com o 1939 Club, razão pela qual o pedido de anulação foi julgado improcedente.

A análise dos casos reunidos na categoria em questão demonstra que as particularidades culturais ou cognitivas do árbitro, para configurarem a aparência de parcialidade, devem ser reconhecidas pelo comportamento pretérito do julgador, ser determinantes para sua avaliação e devem envolver o objeto do litígio.

\subsubsection{Categoria (3.7) - Nacionalidade do árbitro}

Nas arbitragens internacionais, as partes tendem a indicar árbitros da sua própria nacionalidade ou que ao menos comunguem da mesma bagagem cultural e jurisprudencial,

\footnotetext{
${ }^{530}$ Caso Herbert Rebmann et al. v. Peter Rohde et al., 196 Cal.App.4th 1283 (2011). Decisão disponível no endereço eletrônico http://www.leagle.com/decision/In\%20CACO\%2020110628090; consulta em 21.02.2014.
} 
visto que isso facilitaria a compreensão da matéria legal debatida segundo o seu ponto de vista $^{531}$ (o que não significa que, se a lei que regerá a disputa for diferente da nacionalidade da parte, ela não possa preferir um árbitro que não compartilhe de sua nacionalidade, mas que esteja familiarizado com a referida lei de regência ${ }^{532}$ ). A aceitabilidade da escolha por um coárbitro com a mesma nacionalidade das partes, não se estende ao árbitro presidente ao qual a prática da arbitragem e o regulamento de instituições que administram processos impõem que deva ter nacionalidade distinta de ambas as partes. É assim nos regulamentos da CCI (art. 13.5) e do CAM-CCBC (art. 4.15, por requisição das partes), por exemplo.

Há registro de impugnação apresentada em arbitragens ICSID com fundamento na nacionalidade do árbitro. Trata-se do caso Olguín v. Paraguay, no qual o último requereu a desqualificação do árbitro nomeado pelo primeiro, Dale Beck Furnish, que possuía nacionalidade norte-americana, obstada pelo art. 39 do Tratado ICSID e pelo art. 1(3) do Regulamento. Para a constituição do tribunal, o Paraguai havia nomeado árbitro de sua nacionalidade, com a qual Olguín não consentiu. No entanto, após a constituição do tribunal, o Estado descobriu que Olguín, nacional do Peru, também detinha nacionalidade norte-americana, o que justificou a impugnação do árbitro por ele nomeado. $\mathrm{O}$ árbitro renunciou ao encargo ${ }^{533}$.

Em processo arbitral LCIA, o requerido impugnou o árbitro único indicado pela instituição sob a alegação de que, embora não possuísse nacionalidade britânica, ele era de facto um nacional, o que violava o art. 6(1) do regulamento da instituição. A divisão encarregada de decidir a impugnação reconheceu que: $(i)$ a questão da nacionalidade deveria ser analisada quanto à substancialidade, e não de maneira apenas formal; e (ii) há circunstâncias em que a conexão pessoal do árbitro com um país pode ser de tal forma estreita que a nacionalidade formal não garantiria sua neutralidade. No entanto, diante das circunstâncias do caso, a divisão não reconheceu que o árbitro seria um britânico de facto, julgando desprovida a impugnação.

\footnotetext{
${ }^{531}$ DOAK BISHOP; LuCY ReED. Practical... op. cit., p. 401. No mesmo sentido, M. SCOTT DONAHEY. The independence... op. cit., p. 32.

${ }^{532}$ Christopher R. DRAHOZAL. Arbitrator selection ... op. cit., p. 171.

${ }^{533}$ Caso Eudoro Armando Olguín v. República del Paraguay (ICSID Caso n. ARB/98/5). Evento tratado nos parágrafos 15 e 16 do Laudo de 16.07.2001; disponível no endereço eletrônico http://www.italaw.com/sites/default/files/case-documents/ita0586.pdf; consulta em 21.02.2014.
} 
Em um processo arbitral SCC, o requerido, chinês, nomeou como árbitro um profissional que era o "chief judge" da corte da cidade em que o advogado estava registrado. O requerente, japonês, impugnou o árbitro sob a alegação de que os tribunais chineses eram fortemente influenciados por protecionismo e que por isso uma empresa estrangeira em disputa contra uma companhia chinesa não receberia justiça substancial do árbitro chinês. A impugnação foi decidida em desfavor do impugnante ${ }^{534}$.

Os critérios de análise da categoria correspondente à nacionalidade não envolvem não apenas a cidadania do árbitro (sendo essa a mais fácil de verificar), mas também sua residência ou domicílio, sua relação com os ascendentes e até mesmo seus laços com a cultura de determinado país no qual viveu ou no qual viveram seus ascendentes, tal como já se discutiu nas páginas 26 e 27 do presente estudo.

\subsection{Proposta normativa e observador. Diferentes visões?}

Além do ambiente institucional (e de seus protagonistas), a análise da imparcialidade do árbitro deve levar em conta também a referência subjetiva do observador. Essa é premissa que, se não for colocada de modo claro, poderá levar a padrões de análise diferentes e inconciliáveis. E aqui se utiliza o termo "inconciliável" porque certa divergência de análise é até mesmo esperada: não seria de se espantar que a análise da imparcialidade de um árbitro realizada por uma comissão instituída por profissionais atuantes nesse mercado (que talvez pertençam ao mesmo círculo de profissionais com quem o árbitro habitualmente atua) não seja idêntica à análise que o próprio árbitro faz de si, da análise tomada a partir da observação de um particular não afeito à arbitragem, ou ainda da análise de uma das partes.

A imparcialidade, conforme já visto, por configurar a vedação psíquica do árbitro à influência dos argumentos de uma das partes, não pode ser mensurada ou aferida in natura, tendo que ser revelada de acordo com a aparência. E a aparência é o fruto da percepção de

\footnotetext{
${ }^{534}$ MARIE ÖHRSTRÖM. Decisions by the SCC Institute regarding challenge of arbitrators, in Stockholm arbitration report, 2002, n. 1, pp. 39-42.
} 
um sujeito frente ao qual as circunstâncias fáticas se desenrolam, ou seja, é fruto da percepção de um observador.

Como observador privilegiado, um membro da comunidade arbitral à qual pertence o árbitro que tem sua impacialidade escrutinada poderá, na sua observação da circunstância fática do caso, levar em consideração as impressões que já possuía a respeito do profissional. Como observador interessado, uma parte possivelmente partirá da pressuposição de que a parte contrária escolheu árbitro com vistas a potencializar o ganho da causa (um árbitro, portanto, que seja mais influenciável à tese defendida pelo adversário $^{535}$ ), o que aumentará, de modo geral, a disposição dessa parte em observar qualquer fato relativo ao árbitro como uma provável demonstração da sua parcialidade; essa mesma disposição poderá motivar a parte a ser muito mais leniente na observação de qualquer fato suspeito que envolva o árbitro por ela escolhido. É por isso que o dever de revelação é frequentemente ligado à "dúvida justificada" a respeito da imparcialidade do árbitro "aos olhos das partes". Não se pode esperar que elas sejam razoáveis porque, diante do interesse que têm em vencer, as partes são observadores interessados.

Por conta dos diferentes pontos de vista pelos quais as aparências podem ser analisadas, o intérprete deve assumir, o tanto quanto possível, a postura de um observador razoável, de uma pessoa capaz de verificar os eventos fáticos cuja descrição irá constituir a norma concreta do modo mais isento possível na consideração das premissas de estrutura e das premissas de conteúdo.

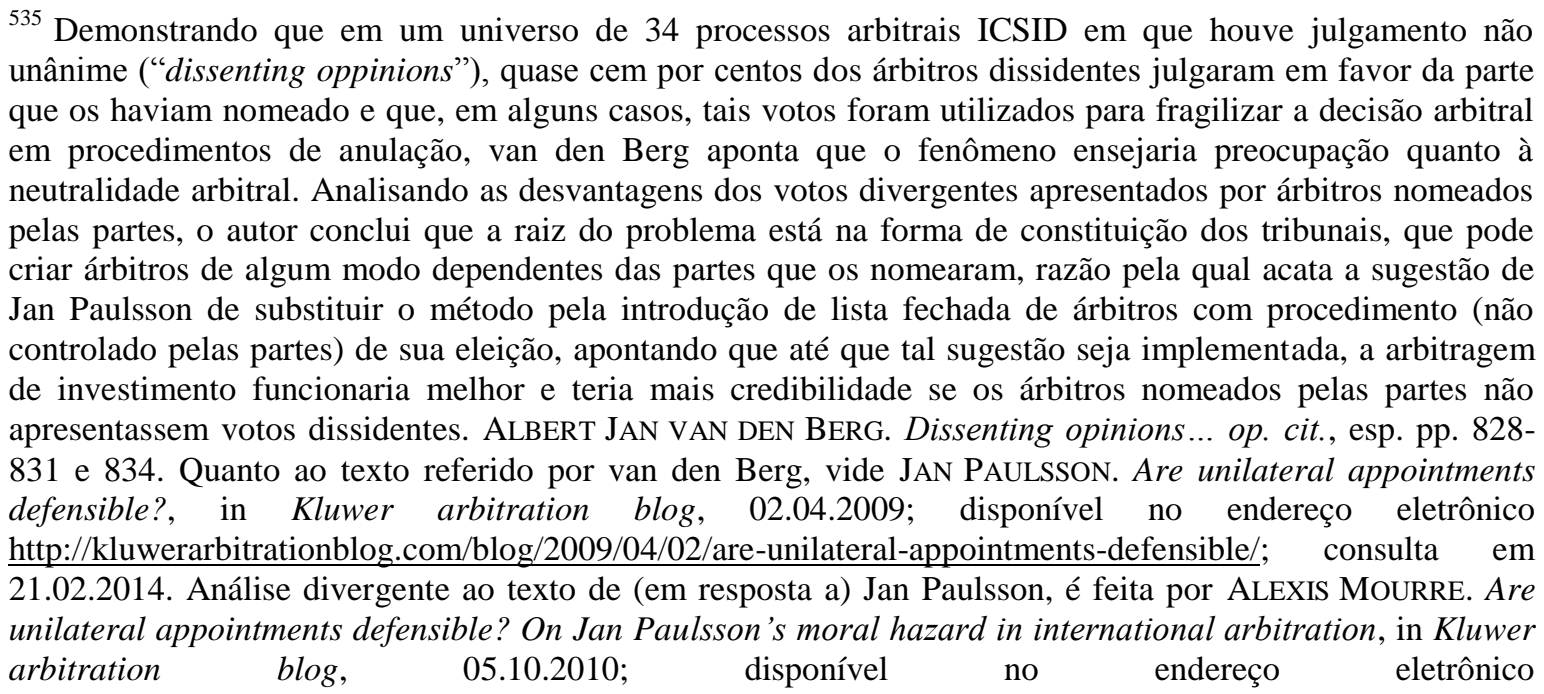
http://kluwerarbitrationblog.com/blog/2010/10/05/are-unilateral-appointments-defensible-on-janpaulsson\%E2\%80\%99s-moral-hazard-in-international-arbitration/; consulta em 21.02.2014. 
É evidente que a separação entre observador e intérprete é algo artificial, visto que se afigura pouco usual ao intérprete dissociar-se da sua própria identidade para se colocar no papel de observador de outra qualidade: como um experiente árbitro aceitará que, sob o ponto de vista de uma das partes, a sua participação em painel de um evento dedicado ao direito discutido na arbitragem, em conjunto com o advogado interno da parte rival, não ensejaria (novamente: sob a ótica de uma das partes) questionamento a respeito da sua imparcialidade? Essa atividade, natural para quem pertence à comunidade arbitral, certamente levantará suspeitas ao leigo.

A jurisprudência do common law, sobretudo a inglesa, dedicou atenção ao tema da imparcialidade para árbitros e juízes, estabelecendo testes nos quais a imparcialidade é analisada sob o ponto de vista da própria corte ou de um observador isento e informado ${ }^{536}$. Um observador justo e equilibrado, na construção inglesa, seria o sujeito ideal que conheceria os argumentos a favor e contrários à identificação da parcialidade do árbitro em um caso concreto, não suspeitando em demasia ou sendo por demais ingênuo, sabendo ponderar os fatos relevantes para sua decisão sobre a lógica do que é socialmente aceito. Ainda que tome por base um sujeito ideal, a padronização do observador pode - e deve ser aceita como parâmetro para a elaboração de proposta normativa a respeito da imparcialidade do árbitro ${ }^{537}$.

Um padrão de observador, ainda que ideal e sujeito a aproximações, deve ser levado em conta. E, para a construção da norma concreta, devem ser afastados os personagens das partes e dos próprios insiders do meio arbitral, que podem levar suas impressões pessoais a respeito do árbitro cuja parcialidade está sob análise. Afastados esses dois extremos, evitase, na medida do possível, um observador que venha a ser corporativista ou complacente demais, ou então rigoroso ou desconfiado demais. O observador deve ser tomado como alguém que, ciente de que a utilização da arbitragem se dá em um mercado relativamente fechado, é capaz de identificar os fatos que levariam à aparência de parcialidade, sem leniência ou, no polo oposto, intransigência quanto à postura socialmente adequada e juridicamente aceitável.

\footnotetext{
${ }^{536}$ Vide capítulo 1.3.3.1 do presente estudo.

${ }^{537}$ Resumo sobre os diferentes "testes" ingleses e os correspondentes pontos de vista dos observadores, vide SAMUEL Ross LutTRELl. Bias... op. cit., pp. 59-61.
} 
Mais uma vez seja reiterada a dificuldade de se apartar o observador do intérprete. Uma vez que a subsunção, como se viu, dá-se através de "idas e vindas" entre a descrição de sentido (juízo) que o intérprete faz do evento do mundo físico e a descrição de sentido (juízo) que o intérprete faz da regra jurídica que entende aplicável, imaginar-se um observador que apenas identifique os fatos na sua "pureza" e mensure a aparência de imparcialidade "em si" é fantasioso; mesmo o observador, para identificar os fatos e para a mensuração da aparência irá recorrer a pautas jurídicas, modelos normativos, decisões em outros casos concretos e diretrizes doutrinárias. Assim, o padrão de observador, mais que uma função positiva, serve para evitar a possibilidade de distorções que ocorreriam se a análise fosse feita "aos olhos das partes" ou "aos olhos dos membros da comunidade arbitral" ${ }^{, 538}$.

A variedade de profissionais envolvidos com a arbitragem (juízes, advogados, potenciais árbitros) e a variedade de instituições arbitrais - tudo potencializado pelas várias legislações nacionais e orientações jurisprudenciais derivadas das diversas nacionalidades nas quais o fenômeno da arbitragem se apresenta, logo, potencializado pelas diferentes heranças jurídico-culturais nacionais - somam mais um grau de dificuldade para a comparação ${ }^{539}$ e consequente eleição de um observador médio, ao qual será ligada formulação de uma proposta normativa. No entanto, essa tarefa não é impossível.

\footnotetext{
${ }^{538}$ Nesse sentido, discutindo o padrão para a lei federal de arbitragem norte-americana: "If the standard of 'appearance of bias' is too low for the invocation of Section 10, and 'proof of actual bias' too high, with what are we left? Profoundly aware of the competing forces that have already been discussed, we hold that 'evident partiality' within the meaning of 9 U.S.C. $\$ 10$ will be found where a reasonable person would have to conclude that an arbitrator was partial to one party to the arbitration. In assessing a given relationship, courts must remain cognizant of peculiar commercial practices and factual variances. Thus, the small size and population of an industry might require a relaxation of judicial scrutiny, while a totally unnecessary relationship between arbitrator and party may heighten it. In this way, we believe that the courts may refrain from threatening the valuable role of private arbitration in the settlement of commercial disputes, and at the same time uphold their responsibility to ensure that fair treatment is afforded those who come before them." Caso Morelite Constr. Corp. v. New York City Dist. Council Carpenters Ben. Funds, 748 F.2d 79, 83-84 (2d Cir.1984), disponível no endereço eletrônico https://law.resource.org/pub/us/case/reporter/F2/748/748.F2d.79.84-7351.86.html; consulta em 21.02.2014.

${ }^{539}$ Thomas E. CARBonneau. The ballad... op. cit, p. 775.
} 


\subsection{Roteiro para a criação de normas concretas}

A norma concreta a ser construída em determinado caso deve ter, em sua raiz, uma regra vinculante, ou seja, um texto dado pela lei ou pelo regulamento aplicável a determinado processo arbitral ou, ainda, por outra forma consensualmente estabelecida pelas partes.

Se a regra trouxer hipótese de fato - com nível suficiente de detalhe - certo evento que o intérprete possa utilizar para a consequência jurídica que defende (parcialidade ou imparcialidade do árbitro), basta ao referido intérprete aproximar o juízo linguísticovalorativo que extrai de tal hipótese ao juízo linguístico-descritivo que se utiliza para descrever o evento efetivamente ocorrido no mundo fático. Com isso, o intérprete aproxima, via subsunção, essas duas descrições ${ }^{540}$. No direito brasileiro, há descrição de algumas hipóteses que "caracterizam os casos de impedimento ou suspeição de juízes" (art. 14 da LA) com nível de detalhe suficiente para a utilização desse método: é o caso do árbitro que, antes de ser nomeado para a função, era advogado de uma das partes no processo arbitral (art. 134, inc. II, do CPC); ou então o caso do árbitro que tiver aconselhado uma das partes sobre a causa (art. 134, inc. IV, do CPC). Essas "relações" (termo usado pelo art. 14 da LA) estão descritas de modo suficientemente detalhado para a aplicação nos casos concretos, permitindo que a imparcialidade seja aplicada como regra $^{541}$

Entretanto, nos casos em que a descrição do evento não se subsumir à descrição da hipótese normativa, o intérprete deverá se utilizar da regra geral do art. $21, \S 2^{\circ}$, da LA, que estabelece um estado de coisas a ser buscado no processo arbitral, demonstrando que o evento do mundo concreto desfavorece essa busca, razão pela qual impõe consequências jurídicas que redirecionem tais eventos ao estado de coisas eleito, seja com a não confirmação do árbitro nomeado, seja com o seu afastamento, seja com a anulação da sentença que este proferiu, seja, ainda, com qualquer outra consequência jurídica que se volte à proteção da imparcialidade. Essa tarefa - muitíssimo mais difícil do que a utilização direta de comportamentos descritos com maior nível de detalhe nas hipóteses de fato das regras vinculantes - ensejará maior profundidade no exame do que o presente

\footnotetext{
${ }^{540}$ KARL ENGISCH. Introdução... op. cit., pp. 78-84.

${ }^{541}$ HUMBerTo Ávila. Teoria... op. cit., p. 85.
} 
estudo optou por denominar premissas de estrutura e premissas de conteúdo. Significa dizer que o intérprete terá maior ônus argumentativo para demonstrar que a norma concreta que ele propõe tem como finalidade a proteção da imparcialidade (e, portanto, da influência dos argumentos das partes na decisão do árbitro) à luz do processo democrático, respeitando os postulados normativos (interpretativos, especialmente o da proporcionalidade) que impõem coesão e coerência dessa norma frente ao sistema jurídico, adaptando-a adequadamente aos eventos que ensejam a aparência de parcialidade. Nesse sentido, a imparcialidade se revela como princípio $^{542}$.

Especialmente nessa segunda acepção, a busca do cumprimento da função da imparcialidade do árbitro não pode ser feita de modo cego e irrealista, pois isso poderia implicar a utilização do instituto como forma de obstar o processo, contrariamente à sua função de promovê-lo de modo democrático (e por isso, mais seguro). Se, de um lado, a tolerância à nomeação de árbitros com critérios muito lassos de imparcialidade permite que profissionais perniciosos venham a ser escolhidos como julgadores, de outro lado, critérios excessivamente rígidos ensejarão uma situação de precariedade do julgador, permitindo a sua desestabilização mediante táticas dilatórias da parte que queira obstar o processo ou anular decisão que prejudique seus interesses ${ }^{543}$. A elaboração da norma concreta relativa à imparcialidade do árbitro tem que ter em vista esse duplo risco e se pautar por um critério de realidade em que a arbitragem é praticada (daí porque atenção deve ser dispensada ao ambiente institucional correspondente e aos padrões de análise de um observador isento), afastando da arbitragem os elementos indesejados sem prejudicar o desenvolvimento do processo ou dar armas àqueles que querem impugnar a arbitragem.

\footnotetext{
${ }^{542}$ HuMBerto Ávila. Teoria... op. cit., p. 85.

${ }^{543}$ WILLIAM W. PARK. Arbitrator integrity... op. cit., p. 634.
} 


\section{CAPÍTULO 4. PRINCIPAIS QUESTÕES LIGADAS À IMPARCIALIDADE DO ÁRBITRO}

\subsection{Padrão de imparcialidade do árbitro e padrão de imparcialidade do juiz}

Ao estabelecer que algumas das "relações" que caracterizam os casos de impedimento e suspeição dos juízes configuram causa para o "impedimento" do exercício da função de árbitro, a LA nada mais fez senão estabelecer uma regra que, por referência, descreve eventos que ensejam a aparência de parcialidade do árbitro. A LA não restringiu os eventos ensejadores da aparência às "relações" características de impedimento e suspeição de juízes, nem estabeleceu, para os eventos previstos, a equivalência de interpretação.

Vale a pena, antes do exame desses dois pontos (não limitação e não equivalência interpretativa dos eventos passíveis de ensejar a aparência de parcialidade do árbitro às hipóteses de impedimento e suspeição dos juízes), destacar as diferenças fundamentais entre árbitro e juiz que, ao final, constituem os vetores determinantes para a orientação tomada pelo presente estudo.

A esta altura, é claro que o ambiente institucional no qual a arbitragem se desenvolve possui características muitíssimo distintas daquele em que se desenvolve o processo jucidial. O julgador no processo judicial é funcionário estatal, que geralmente é sorteado para a atuação em determinado caso, enquanto o árbitro é um profissional atuante no mercado, que é escolhido direta ou indiretamente pelas partes para a solução de uma controvérsia $^{544}$. Por conta disso, é possível - e até mesmo esperável - que entre árbitro e

\footnotetext{
${ }^{544}$ A dinâmica de as partes escolherem, cada uma, um árbitro para compor o tribunal arbitral é a prática mais comum, a despeito das diretas colocações de Paulsson no conhecido texto "Moral Hazard", no sentido de que essa prática gera dissonâncias cognitivas nas partes (entre elas, de que o árbitro irá “ajudar” a parte a vencer o caso; de que as partes terão mais confiança nos árbitros que selecionarem; e de que o árbitro indicado irá assegurar que o tribunal, como um todo, entenda a "cultura" da parte) e somente favorece o assédio moral da parte sobre o árbitro nomeado, que pode (tal como em casos narrados no texto, especialmente quando os vínculos do árbitro com a parte são profundos mas não conhecidos, quando o árbitro for inexperiente, ou mesmo quando mal-intencionado) resultar em sentença maculada pela parcialidade do árbitro. Pregando, ao final, que isso somente poderia ser evitado pela proibição - ou ao menos a rigorosa fiscalização - da prática de nomeações unilaterais, substituindo-a pela indicação por um órgão neutro, JAN PAULSSON. Moral... op. cit., esp. pp. 8-14.

O problema dessa proposta é a garantia de que tal órgão exista e assim permaneça. Vide, por exemplo, o caso da CICA-CCIR, que em 2012 alterou seu regulamento para retirar das partes a faculdade de nomeação do
} 
partes (ou seus advogados) possam ter se estabelecido contatos pretéritos que, ao final, ensejaram sua nomeação. A parte ou seu advogado podem ter tido contato com o trabalho acadêmico do árbitro, com petição escrita por ele em caso não sujeito a sigilo, assistido à palestra ou participado de outro litígio e, assim, conhecido o posicionamento do árbitro relativamente à determinada questão jurídica que seria, em princípio, favorável à tese que a parte ou seu advogado irão defender no processo arbitral ${ }^{545}$. Essa escolha do julgador aparentemente mais favorável à tese de uma das partes é impensável no processo judicial, no qual o órgão julgador preexiste à controvérsia e é ocupado por pessoa de acordo com regras administrativas totalmente alheias à vontade das partes.

Por ser funcionário estatal, o juiz sorteado não depende de seu capital simbólico no mercado jurídico, nem sua remuneração se vincula a esse fator ${ }^{546}$. Igualmente, o juiz não pode esperar que seu desempenho na solução da controvérsia tenha efeito direto sobre o encaminhamento de novos $\operatorname{casos}^{547}$. O profissional que atua como árbitro (e também como advogado, algo impensável para um juiz) pertence a um mercado próprio e pode esperar isso.

Essas significativas diferenças estabelecem, para o árbitro, toda uma nova série de riscos à imparcialidade que inexistem para o juiz. Se, de um lado, torna-se necessário reconhecer a existência de contatos pretéritos entre árbitro e parte (ou seu advogado) como determinante para a escolha do julgador com maior probabilidade de acatar a tese da parte que o escolheu, por outro, não se pode permitir que esses contatos se deem em grau suficiente para ensejar a aparência de parcialidade. Tome-se como exemplo a decisão do TJSP, que considerou não ser suspeito o juiz que é cliente do advogado de uma das partes, por

árbitro para atribuí-la ao Presidente da instituição, que passou a receber 10\% da remuneração do árbitro (arts. 11 e 14(7) do regulamento). A regra de nomeação institucional, nessas bases, inegavelmente gera muito mais insegurança que a regra de nomeação pelas partes. O regulamento da CICA-CCIR pode ser consultado no endereço eletrônico http://arbitration.ccir.ro/engleza/Rules_on_the_organization_and_operation_of_the_Court_of_International Commercial_Arbitration_of_the_Romanian_Chamber_of_Commerce_and_Industry.pdf; e comentários às alterações regulamentais podem ser consultados no endereço eletrônico http://www.legal500.com/c/romania/developments/21999; consulta em 21.02.2014.

545 YUVAL SHANY. Squaring... op. cit., p. 479.

${ }^{546}$ É necessário reconhecer que a promoção de um juiz por merecimento, prevista no art. 95, inc. II, da Constituição Federal e estabelecida pelo art. 80, § 1º, inc. II, da Lei Complementar 35/1979 (LOM), produz reflexos na sua remuneração. No entanto, essa promoção depende da satisfação de requisitos reconhecidos por órgão administrativo do Poder ao qual o juiz se vincula; e não do capital simbólico conquistado perante os próprios destinatários das suas decisões, consoante as regras de mercado.

${ }^{547}$ Idem à observação anterior. 
inexistir previsão nesse sentido, aliada a uma incabível "pessimista concepção do ser humano" 548 . Tal como se viu, em razão do ambiente institucional no qual a arbitragem se desenvolve $^{549}$, o árbitro que possui relações negociais com o advogado (tendo causa patrocinada por este) ensejará, a princípio, forte aparência de parcialidade, pois aparentará estar imunizado aos argumentos do adversário do seu patrono, em cuja atuação, além de confiar, irá lhe trazer benefícios caso seja bem-sucedida no processo de seu interesse.

Ademais, por geralmente cumularem a função de árbitros com a de advogados, situações impensáveis para o juiz podem ocorrer para os profissionais da arbitragem. É o caso de o árbitro ter que julgar litígio cuja decisão será útil para a defesa de tese que esse mesmo profissional defende, na qualidade de advogado, em outro processo ${ }^{550}$. Aqui, mais uma vez, a superação da noção genérica de imparcialidade como possibilidade de o árbitro julgar com base em influências outras que não apenas os argumentos das partes, e a sua fixação como vedação da influência das partes no convencimento do árbitro, é de vital importância. Tomem-se duas hipóteses. Na primeira, o árbitro defende, em processo que envolve outras partes, tese para a qual sua sentença é útil e proveitosa em razão da identidade da questão de direito (discussão sobre a aplicação da mesma regra e, portanto, da mesma consequência jurídica) e da extrema similitude da questão de fato (identidade da descrição dos eventos relevantes). Ao decidir, o árbitro certamente estará influenciado pela sua preparação como advogado e, mais que isso, tirará proveito da sua própria decisão, a ponto de aparentar estar imunizado à influência da tese oposta àquela que está defendendo no momento. Em uma segunda hipótese, o árbitro defendeu, em processo estabelecido entre partes diferentes e já findo, tese semelhante à que deve julgar. Aqui também é provável que os estudos e os trabalhos pretéritos do árbitro como advogado (ou seja, sua própria experiência e pré-compreensão como indivíduo) influenciem, sim, sua decisão. Assim, se a parcialidade for tomada - tal como faz a doutrina - como exposição do árbitro a influências outras que não os argumentos das partes, ela se fará presente também nessa segunda hipótese. No entanto, não haverá qualquer proveito imediato para o árbitro julgar no mesmo sentido da tese que defendeu, de modo que ele, aparentemente, não está imunizado aos argumentos contrários. Nessa segunda hipótese, tal como na primeira, o

\footnotetext{
${ }^{548}$ Caso em segredo de justiça, ES 8.295-0, C. Esp., TJSP, j. 10.03.1988, in Revista dos Tribunais, v. 631, 1988, p.83.

${ }^{549}$ Vide capítulo 3.3 do presente estudo.

${ }^{550}$ Vide capítulo 3.4.7 do presente estudo.
} 
árbitro estará influenciado pela sua experiência como advogado (o que levaria ao intérprete que tomasse a influência externa do árbitro como causa de parcialidade a sancionar igualmente as hipóteses); no entanto, na segunda hipótese é bem menos aparente a vedação do árbitro à influência dos argumentos relativos à tese contrária à qual defendeu como advogado, diferentemente do que ocorre na primeira hipótese, na qual a sua decisão como árbitro dá-se no sentido de - e reforça a - sua posição como advogado no processo em curso. Assim, os dois casos apenas serão diferenciados (o que já ocorreu, mesmo sem explicação técnica ${ }^{551}$ ), se a parcialidade for tomada como a vedação à influência exercida pelos argumentos da parte, e não como influência de elementos extra autos na decisão.

Conforme já antecipado, as diferenças fundamentais entre o estatuto do árbitro e do juiz demandam não apenas a construção de normas concretas aplicáveis somente ao primeiro (derivadas, como já se viu, da regra geral que impõe um estado de coisas relativamente à imparcialidade do árbitro), como também uma interpretação particular das causas de impedimento e suspeição previstas na lei (além de outras regras vinculantes), interpretação essa que, para o árbitro, afasta-se da interpretação aplicável ao juiz.

Tome-se o exemplo da causa de impedimento prevista no art. 134, inc. III, do CPC. A interpretação corrente da regra no STJ é no sentido de reconhecer o impedimento do magistrado que tenha atuado previamente no litígio no exercício da função jurisdicional, e não quando tenha atuado na esfera administrativa ${ }^{552}$. Assim, o mesmo magistrado pode decidir na esfera administrativa sobre uma controvérsia (geralmente ligada à distribuição de delegações de serventias extrajudiciais ou a processos administrativo-disciplinares) e, posteriormente, decidir o tema quando objeto de demanda judicial ${ }^{553}$. Essa interpretação da regra não pode ser aplicada na arbitragem. Imagine-se o caso em que o árbitro é também o responsável, em certa entidade que administra processos arbitrais, pelo exercício do juízo de arbitrabilidade da controvérsia e sua admissão prima facie para a constituição de um processo arbitral. Nesse exemplo, o conhecimento prévio do árbitro a respeito da

\footnotetext{
${ }^{551}$ Vide casos tratados no capítulo 3.4.7 do presente estudo.

${ }^{552}$ STJ, RMS 18.099/PR, $5^{\mathrm{a}}$ T., Rel. Min. Arnaldo Esteves Lima, DJ 12.06.2006, p.500. Também STJ, RMS 13308/DF, 6 $6^{\mathrm{a}}$ T., Rel. Min. Maria Thereza de Assis Moura, DJe 04.08.2008.

${ }^{553}$ No entanto, registre-se o reconhecimento do impedimento, para a decisão de processo judicial, do magistrado que foi o relator do processo administrativo-disciplinar, no qual se manifestou de forma conclusiva e antecipada acerca da controvérsia (no caso, dando pela culpabilidade do agente público, "proferindo seu voto-condutor com base em ideias preconcebidas que vincularam o resultado final da esfera disciplinar"). STJ, RMS 19.477/SP, 6a T., Rel. Min. Maria Thereza de Assis Moura, DJe 22.02.2010.
} 
controvérsia - e, pior, o seu posicionamento a respeito de uma das questões objeto do litígio: a arbitrabilidade - impõem diferente interpretação e qualificação ${ }^{554}$ dos termos presentes no texto do artigo em tela, levando ao estabelecimento de uma norma distinta daquela reconhecida para os magistrados, de modo que, independentemente do estágio em que tenha tomado conhecimento do conflito (isto é, atuado nele), esse evento configure causa aparente de sua parcialidade.

Seja com a ampliação das causas que aparentam a parcialidade do árbitro para além daquelas previstas ao juiz, seja com a particular interpretação daquelas previstas em lei, é possível perceber que a sistemática aplicável à imparcialidade do árbitro deve reconhecer a existência de um mercado e de uma comunidade arbitral inexistentes no processo judicial e, sobretudo, de uma lógica diferente na escolha e regulação de conduta do julgador em cada um dos métodos. O árbitro é escolhido, sobretudo, pelo seu capital simbólico, que muitas vezes presume algum tipo de contato entre o julgador e a parte ou seu advogado ${ }^{555}$. Não considerar esses fatores quando o intérprete propõe uma norma concreta que dê pela parcialidade ou imparcialidade do árbitro é correr o risco de tomar relações indiretas e precárias entre árbitro e parte como evento ensejador da aparência de parcialidade ou, de outro lado, tomar relações diretas e substanciais como insuficientes para caracterizar essa mesma parcialidade ${ }^{556}$.

\subsection{Imparcialidade, independência e neutralidade do árbitro: importância relativa das distinções}

O presente estudo já expôs a relevância que os regramentos, a doutrina e as decisões (proferidas em processos arbitrais ou pelo Poder Judiciário) conferem à conjunção dos

\footnotetext{
${ }^{554} \mathrm{O}$ problema de interpretação volta-se à atribuição de significado a um termo linguístico utilizado em um enunciado normativo, ao passo que o problema de qualificação se volta à classificação de determinado fato ocorrido no mundo da vida (ou melhor, ao termo linguístico que descreve determinado fato) ao termo linguístico utilizado na regra. Sobre a diferenciação, vide NEIL MACCORMICK. Argumentação... op. cit., pp. 119-121.

${ }^{555}$ YUVAL SHANY. Squaring... op. cit., p. 487.

${ }^{556}$ Conforme já decidido: "Given these differences, it is clear that the actual standard for arbitrators does differ from that for judges, even though language used to describe both standards may be similar". Caso Jean Schmitz; Leonard Schmitz v. Carlos J. Zilveti, III; Nicholas S. Meris; Prudential-Bache Securities Inc., $20 \quad$ F.3d $1043 \quad\left(9^{\text {th }} \quad\right.$ Cir. 1994), disponível no endereço eletrônico https://law.resource.org/pub/us/case/reporter/F3/020/20.F3d.1043.92-16853.html; consulta em 21.02.2014.
} 
termos "imparcialidade e independência"557. Até mesmo a LA assim o faz no arts. $13, \S 6^{\circ}$ e $14, \S 1^{\circ}$. O presente estudo também expôs a noção geral de independência para a arbitragem e os diversos entendimentos a respeito da sua relação com a imparcialidade, colocando o problema principal de sua inaplicabilidade para a solução de casos $\operatorname{concretos}^{558}$.

A noção geral de independência do julgador não é originária da arbitragem, mas antes da Teoria Política e do Direito Constitucional, estando, portanto, ligada ao exercício do poder estatal e à separação dos seus poderes ${ }^{559}$. Prova-a a própria Constituição Federal brasileira, ao consagrar no seu art. $2^{\circ}$ que "[s]ão Poderes da União, independentes e harmônicos entre si, o Legislativo, o Executivo e o Judiciário".

O Direito Processual também trata do tema da independência judicial, reconhecendo nela um valor e uma garantia que abarcam tanto o juiz (internamente e externamente à magistratura) quanto o próprio Poder Judiciário ${ }^{560}$. No que concerne à pessoa do juiz, a independência externa visa protegê-lo das pressões exteriores ao Poder Judiciário, ao passo que a independência interna visa ampará-lo dentro da própria instituição, envolvendo mecanismos (garantias e proibições) que a materializam, tais como a seleção com base em qualificações adequadas, vitaliciedade, irredutibilidade de vencimentos, inamovibilidade, proibição de filiação partidária, entre outras ${ }^{561}$. A independência do Poder Judiciário é instrumentalizada pela sua autonomia e autogoverno, desvinculados dos outros Poderes políticos do Estado ${ }^{562}$. De modo mais teórico, a independência "no es más que aquella

\footnotetext{
${ }^{557}$ Vide capítulo 1.2.1 do presente estudo.

${ }^{558}$ Vide capítulo 1.2.2 do presente estudo.

${ }^{559}$ A ideia de separação dos poderes atribuída a Montesquieu não atribuía papel de relevância ao Judiciário, não entendido como poder nos mesmos termos que o Legislativo e o Executivo, mas sim como uma mera função. Foram a obra dos federalistas norte-americanos (Madisson, Jefferson e Hamilton) e a Declaração de Direitos Humanos francesa - cada qual com suas características peculiares - que atribuíram ao Poder Judiciário o "seu lugar ao sol" e reconheceram sua independência. José LuIZ DE ANHAIA MELlO. Da separação de podêres à guarda da constituição: as côrtes constitucionais. Dissertação para concurso à cátedra de Direito Constitucional da Faculdade de Direito da Universidade de São Paulo. São Paulo, 1968.

${ }^{560}$ LuIz Flávio Gomes. A questão do controle externo do Poder Judiciário: natureza e limites da independência judicial no Estado Democrático de Direito. São Paulo: RT, 1993, p. 58.

${ }^{561}$ JuAn Montero ArocA. Independencia y responsabilidad del juez. Madrid: Civitas, 1990, pp. 56-84. Também JAYME BENVENUTO LIMA JÚNIOR (Ed.). Independência dos juízes no Brasil: aspectos relevantes, casos e recomendações. Recife: Gajop; Bagaço, 2005, pp. 68-69.

${ }^{562}$ LUIZ Flávio Gomes. A questão... op. cit., pp. 65-73. Nos mesmos termos, o Direito Processual Civil não desconhece as garantias institucionais do Poder Judiciário (autonomia orgânico-administrativa e
} 
institución jurídica en virtud de la cual el sistema delimita com precisión el sector del ordenamiento que encierra los elementos relevantes para el Juez a la hora de ejercer jurisdicción”, barrando “injerencias de otros órganos ${ }^{563}$, distinguindo-se da independência, que seria apenas "modelos de actuación que el ordenamiento desea para los Jueces",564.

Como não é integrante de qualquer órgão da administração da justiça (ao qual não se equiparam eventuais "listas de árbitros" elaboradas por instituições que administram processos arbitrais), mas sim escolhido direta ou indiretamente pelas partes para a solução de uma disputa específica, ao tribunal arbitral não aproveita a noção de independência nos moldes do processo estatal ${ }^{565}$. Por essa razão, doutrina e jurisprudência utilizaram o termo para identificar - de modo supostamente objetivo - a inexistência de relação ou ligação do árbitro frente às partes fora do processo arbitral ${ }^{566}$.

Embora seja corrente a afirmação - feita sem maiores reflexões - de que a verificação da independência do árbitro se daria de modo objetivo, mediante a identificação da relação árbitro-partes, é também corrente a adjetivação dessa relação para a configuração da dependência, de modo que apenas as relações "de subordinação" ${ }^{567}$ ou "inapropriadas" "568, ou ainda as que "influenciassem na decisão do árbitro" 569 a ensejariam. Qualquer desses qualificadores torna necessário um juízo de valor sobre a relação, eliminando a suposta

independência financeira - arts. 96 e 99 da Constituição Federal) e as garantias funcionais do Poder Judiciário ou garantias da magistratura (vitaliciedade, inamovibilidade e irredutibilidade de vencimentos art. 95 da Constituição Federal). HumBerto TheOdoro Júnior. Curso de Direito Processual Civil, v. I, 51. ed. Rio de Janeiro: Forense, 2010, pp. 208 e 212.

563 JUAN LUIS REQUEJO PAGÉS. Jurisdicción e independencia judicial. Madrid: Centro de Estudios Constitucionales, 1989, p. 164.

${ }^{564}$ JUAN LUIS REQUEJO PAGÉS. Jurisdicción... op. cit., p. 167. Contra, por entender que a independência relaciona-se ao órgão jurisdicional e que a imparcialidade diz respeito ao juiz, LUIS ALBERTO REICHELT. $O$ direito fundamental das partes à imparcialidade do juiz no direito processual civil, in Revista de processo, $\mathrm{v}$. 227, 2014, p. 111.

${ }^{565}$ Apontando que a constituição do tribunal arbitral (para decidir caso específico consoante escolha direta ou indireta pelas partes torna muitos dos requisitos de independência desenvolvidos para os órgãos jurisdicionais irrelevantes, FABIEN GÉLINAS. The independence of international arbitrators and judges: tampered with or well tempered?, in New York international law review, v. 24, n. 1, 2011, pp. 35-36.

${ }^{566}$ Vide capítulo 1.2 do presente estudo.

${ }^{567}$ Carlos Alberto Carmona. Arbitragem... op. cit., p. 242

${ }^{568}$ WILlIAM W. PARK. Arbitrator integrity... op. cit., P. 637.

${ }^{569}$ É o que fazem, utilizando a decisão do caso ICSID Suez v. Argentina, NoAH RUBINS; BERNHARD LAUTERBURG, Independence, impartiality and duty of disclosure in investment arbitration, in CHRISTINA KNAHR et al. (Ed.). Investment and commercial arbitration - similarities and divergences, Utrecht: Eleven International Publishing, 2010, pp. 154-155. 
objetividade da noção de independência ${ }^{570}$. Mais: o conjunto das relações causadoras da dependência frequentemente é expandido para as afetivas, morais, espirituais ${ }^{571}$ ou psicológicas $^{572}$, ou ainda para aquelas travadas, não pelo árbitro, mas por pessoas próximas a ele ${ }^{573}$, o que torna ainda mais difícil a constatação objetiva da independência ${ }^{574}$. Pior seria o reconhecimento da dependência pela existência de qualquer vínculo entre parte $\mathrm{e}$ árbitro, sem qualquer qualificador ${ }^{575}$, pois isso tornaria absolutamente impossível a prática arbitral no ambiente institucional já apresentado no presente estudo.

De fato, a dificuldade de estabelecimento do conteúdo próprio do termo "independência" é tão grande que, após narrar sua noção geral, alguns autores preferem tratar diretamente dos casos típicos que a doutrina e a prática reconhecem envolver a dependência, tais como a relação negocial do árbitro com as partes ou com seu advogado, as nomeações repetitivas do árbitro, contatos ex parte antes da nomeação, entre outros ${ }^{576}$.

Não causa qualquer espanto a falta de convergência nas noções de independência para a arbitragem e no abandono de uma definição mais precisa. Diferentemente da imparcialidade, que possui uma função estrutural no processo ao possibilitar o exercício da influência dos argumentos das partes ${ }^{577}$, a independência nada agrega ou retira dela. Na arbitragem, não há que se legitimar a sujeição das partes a uma decisão porque o órgão decisor foi composto pelas próprias partes em disputa (conforme colocado acima, essa função legitimadora é exercida pela noção de independência do Poder Judiciário no

\footnotetext{
${ }^{570}$ Não por outra razão há o antigo alerta de que a objetividade da análise da independência não deve ser superestimada. HORACIO GRIGERA NAÓN. Factors to consider in choosing an efficient arbitrator, in ALBERT VAN DEN BERG (Ed.). Improving the efficiency of arbitration agreements and awards: 40 years of application of the New York Convention, ICCA Congress Series n. 9 (Paris, 1998), The Hague: Kluwer Law International, 1999, p. 289.

${ }^{571}$ Carlos Alberto Carmona. Arbitragem... op. cit., p. 242.

572 Tratando do conceito de "dependência psicológica", MAURO RUBINO-SAMMARTANO. International arbitration law and practice, 2. ed. The Hague: Kluwer Law International, 2001, p. 330.

${ }^{573}$ YVES DERAINS; ERIC SCHWARTZ. A Guide to the ICC Rules of Arbitration, 2. ed. The Hague: Kluwer Law International, 2005, p. 121.

${ }^{574}$ Para mais observações sobre o tratamento do tema pela doutrina brasileira, vide capítulo 1.4 do presente estudo.

${ }^{575}$ Nesse sentido: “A postura independente do árbitro frente às partes traduz-se na inexistência de qualquer relação ou vínculo deste com aquelas ou com alguma pessoa estritamente vinculada a elas, sejam essas relações ou vínculos de caráter pessoal, social, econômico, financeiro ou de qualquer outra natureza." AdRIANA NoEMI PUCCI (Ed.). Arbitragem comercial internacional, São Paulo: LTr, 1998, p. 121.

${ }^{576}$ Exemplo é a obra de YVES DERAINS; ERIC SCHWARTZ. A Guide ... op. cit.,5, pp. 123-134.

${ }^{577}$ Sobre o tema, vide capítulo 2.1.1 do presente estudo.
} 
processo estatal). $\mathrm{Na}$ arbitragem, as partes provavelmente escolherão como árbitro profissional que já conhecem e com quem já travaram alguma relação ${ }^{578}$. Na arbitragem, perde a legitimidade o julgador cuja relação com uma das partes ultrapassa o limite aceitável, identificável quando tal relação é estreita e significativa o suficiente para ensejar a aparência de que ele seria impermeável aos argumentos apresentados por uma das partes, ou seja, a partir de quando a relação enseja a aparência de parcialidade. Não é por outra razão que a doutrina vê na falta de independência do árbitro apenas um indicativo da aparência de parcialidade ${ }^{579}$.

Para que reste claro: a independência do árbitro não possui função processual própria, diferentemente da imparcialidade. Quando muito, a primeira pode ser: (i) um indicativo da segunda, pois quando identificada uma relação que envolve a noção de independência, ou melhor, a ausência dela nessa relação, poder-se-á analisar se ela satisfaz as premissas de estrutura e conteúdo que caracterizam a parcialidade do árbitro; ou (ii) um guia para que o árbitro exerça seu dever de revelação, apontando as relações que manteve ou mantém com as partes e que poderiam, aos olhos destas, ser indicativo de aparência de parcialidade.

Essa função meramente indicativa da independência torna desnecessária sua conceituação precisa, bem como a criação de um método para sua exata identificação ${ }^{580}$. É no âmbito da imparcialidade que as análises úteis efetivamente se dão.

A conclusão acima exposta permite uma leitura dos arts. $13, \S 6^{\circ}$, e $14, \S 1^{\circ}$, da LA (e todos os regramentos que utilizam o termo "independência" junto ao termo "imparcialidade" ${ }^{581}$ )

\footnotetext{
${ }^{578}$ Sobre o tema, vide capítulo 3.3 do presente estudo.

${ }^{579}$ Nesse sentido: "Lack of independence is a pointer towards potential partiality. It is possible (if unlikely) that an arbitrator may not be entirely independent of both parties as a result of a relationship with one or the other or a connected third party, but may be able to set aside that relationship and come to a decision entirely impartially, based on the facts and the relevant law alone." RONNIE KING; BEN GIARETTA. Independence, impartiality and challenging the appointment of an arbitrator, in The international comparative legal guide to: international arbitration 2005, London: Global Legal Group, 2005, p. 27. No mesmo sentido: "Naturally, the more dependent an arbitrator is vis-à-vis a party, the less impartial he will be seen (objectively) to be." NOAH RUBINS; BERNHARD LAUTERBURG, Independence ... op. cit., p. 156.

${ }^{580}$ A jurisprudência inglesa, mais afeita à prática que à sistematização, foi precisa na decisão do caso $A T \& T$ (vide notas de rodapé $\mathrm{n}^{\text {os }} 140$ e 141), ao reconhecer a função indicativa da independência frente à parcialidade, sem sequer fazer referência a esses termos, ao declarar que ela constituía "an absence of connection with either of the parties in the sense of an absence of any interest in, or of any present or prospective business or other connection with, one of the parties, which might lead the arbitrator to favour the party concerned'an absence of connection with either of the parties in the sense of an absence of any interest in, or of any present or prospective business or other connection with, one of the parties, which might lead the arbitrator to favour the party concerned".
} 
sem a vulneração das bases e efeitos do contrato de arbitragem ou das bases e efeitos da relação processual, além de atender à realidade do ambiente institucional onde a arbitragem se desenvolve. Colocando-se a dependência (ainda que identificada pela vaga noção contrária de independência) como indicativo da parcialidade e dando-se foco nessa última, é possível não só proteger o contrato de arbitragem mediante o dever de revelação - que passa a ter critério mais firme, eliminando uma série de problemas concretos que afligem os profissionais nomeados como árbitros quanto às relações que devem revelar -, como também proteger a relação processual mesma - de modo que apenas a dependência (noção vaga) que enseje a aparência de parcialidade (conceito verificável e mensurável no caso concreto mediante critérios que compõem premissas de estrutura e conteúdo, conforme o presente estudo apontou) seja suficiente para macular o processo.

Com essa orientação, é possível obter maior segurança (vedando a atuação, preventivamente ou no curso do processo arbitral, de árbitros aparentemente parciais) ao mesmo tempo em que torna mais difícil a utilização da noção de independência em manobra dilatória executada pela parte que quer tumultuar o processo arbitral.

As afirmações relativas à independência sustentam, com ainda mais vigor, a desimportância da noção de neutralidade para a configuração da aparência de parcialidade do árbitro. A neutralidade nada mais é que a identificação do árbitro com algum grupo de indivíduos ao qual pertence uma das partes, envolvendo, predominantemente, nacionalidade e religião, podendo sua ausência ser reconduzida à noção de dependência e, quando ensejar a aparência de vedação do árbitro à influência das partes, ao próprio conceito de parcialidade. Se o grupo ao qual pertencem árbitro e parte for pequeno demais (como, por exemplo, o de um clube social), a aparência de parcialidade será ensejada pelo contato direto entre ambos - relação direta, característica da noção de dependência -, e não pelo mero pertencimento ao grupo (se não houver relação direta, dificilmente o

\footnotetext{
${ }^{581}$ Não por outra razão, Hedfern e Hunter apontam que os termos são "usually joined together as a term of art". Alan RedFern; MARTin Hunter; Nigel Blackaby; Constantine Partasides. Law and practice of international commercial arbitration, 4. ed. London: Sweet \& Maxwell, 2004, p. 20. Na edição mais recente, que contam com Blackaby e Partasides como colaboradores principais e na qual Hedfern e Hunter passam a nomear a obra, essa referência foi retirada, com a apresentação de tentativa de distinguir os conceitos de imparcialidade e independência nos termos da doutrina convencional, tratados no presente capítulo. Vide MARTIN HUNTER; Nigel BlACKABY; CONSTANTINE PARTASIDES. Hedfern and Hunter on... op. cit., pp. 267268.
} 
pertencimento ao mesmo clube social caracterizará a aparência de parcialidade). Se o grupo ao qual pertencem árbitro e parte for grande (como, por exemplo, o de uma identidade nacional), a aparência de parcialidade poderá ser ensejada pela particularidade cultural ou cognitiva do árbitro ${ }^{582}$ : compare-se o exemplo do árbitro que nasceu e continua a viver em um país, e que julgará disputa que envolve interesses do Estado, com o exemplo do árbitro que apenas nasceu em um país, do qual tornou-se nacional conforme o ius soli, retornando ao país de origem dos seus ascendentes, e que julgará interesses de companhia que possui a mesma nacionalidade. Parece claro que a aparência de parcialidade do árbitro no primeiro exemplo (derivada das particularidades culturais e cognitivas do árbitro, que está exposto, estreitando e fortalecendo a identidade do árbitro com a parte por meio da nacionalidade) é muito maior que a aparência de parcialidade do árbitro no segundo exemplo (no qual essas particularidades que estreitam e fortalecem a identidade do árbitro com a parte através da nacionalidade não estão presentes) ${ }^{583}$.

Felizmente, no que diz respeito à nacionalidade do árbitro, as instituições que administram processos arbitrais contam com regras sancionadoras específicas, proibindo a identidade com a nacionalidade das partes nas arbitragens internacionais (quando as partes tiverem diferentes nacionalidades). A violação de disposição expressa no regulamento estabelecido pelas partes quanto à nacionalidade - tal como ocorre no art. 13.5 do regulamento CCI, nos arts. 38 e 39 da Convenção ICSID e art. 1(3) do regulamento ICSID, no art. 6 da LCIA (que inclui no conceito de nacionalidade da parte a nacionalidade dos acionistas controladores), e no art. 4.15 do regulamento do CAM-CCBC, por exemplo - pode acarretar a anulação do processo e da sentença arbitral por conta do desatendimento à convenção de arbitragem (art. 32, inc. IV, LA $^{584}$ ), e não diretamente pela aparência de

\footnotetext{
${ }^{582}$ A identificação da neutralidade como nacionalidade - e dessa com a aparência de parcialidade - é colocada nos devidos termos por Lalive, ao afirmar que ela é "supposed implications: by an instinctive reaction, parties will generally assume without much further thought that a prospective arbitrator is likely, or even bound, to share his country's ideology and common values, if any", pela qual "an unhealthy atmosphere of doubt and fear is likely to appear" PIERRE LALIVE, On the neutrality... op. cit., pp 25-26. No mesmo sentido, afirmando que há um maior grau de confiança em todos os participantes do processo arbitral "if there is no chance that one party will get a better hearing because of some cultural or national identification between the party and the arbitrator". TOBY LANDAU, Composition ... op. cit., p. 73.

${ }^{583}$ Não se pode deixar de fazer referência ao alerta de que "a principled approach to group-biases is next to impossible. The exclusion of individuals [as arbitrators], because of their group affiliation, opens a Pandora's box". TIBOR VÁRAdY; John J. BARCELó III; ARTHUR TAYLOR VON MEHREN. International commercial... op. cit., p. 266.

${ }^{584}$ Assim: "[s]ob outro ponto de vista, seria possível também sustentar que a sentença arbitral padeceria do vício de que trata o inciso IV do art. 32 quando ficar caracterizado que os árbitros desviaram-se do procedimento estipulado pelas partes." CARLOS ALBERTO CARMONA. Arbitragem... op. cit., p. 406.
} 
parcialidade do árbitro. Essa interpretação é muito mais segura e direta, abarcando até mesmo os casos em que a identidade nacional entre árbitro e parte não seja forte o suficiente para ensejar (mediante a análise dos critérios relativos às particularidades culturais e cognitivas do árbitro) a aparência de parcialidade.

O tratamento da neutralidade nos termos propostos pelo presente estudo, a exemplo do que faz quanto à independência, torna a utilização do método arbitral mais segura (ao afastar árbitros cuja identidade de grupo com a parte aparente sua parcialidade) e menos sujeita a táticas dilatórias (retirando a possibilidade de que qualquer identidade de grupo seja utilizada para impugnação do árbitro).

\subsection{Imparcialidade e dever de revelação}

Tema fortemente ligado à imparcialidade é o dever de revelação, por parte do árbitro, de todos os eventos, circunstâncias, fatos e ligações que possam dar ensejo à aparência de parcialidade. De posse dessas informações previamente à aceitação do encargo pelo árbitro prospectivo, as partes terão condições de avaliá-las, assim coibindo que figure como árbitro profissional que ostente aparência de parcialidade.

Dada a sua importância para a higidez do processo arbitral como instrumento voltado à manutenção da imparcialidade do árbitro ${ }^{585}$, virtualmente todos os regulamentos de instituições arbitrais e grande parte das legislações nacionais preveem o dever de revelação. $\mathrm{O}$ art. 1.456 do Code de Procédure Civile francês (pela redação dada pelo Décret n²011-48 du 13 janvier 2011) estabelece que "[c]abe ao árbitro, antes de aceitar a missão, divulgar quaisquer circunstâncias suscetíveis de afetar a sua independência ou imparcialidade ${ }^{, 586}$; No mesmo sentido vão o $§ 1.036$, I, da Zivilprozessordnung alemã $\tilde{a}^{587}$ e

\footnotetext{
${ }^{585}$ O dever de revelação serve como "purga do sistema", confome as palavras de THOMAS ClAY. Arbitrage et modes alternatifs de règlement des litiges, in Recueil Dalloz, n. 44/7537, 27.12.2012, pp. 2998-2999.

${ }^{586}$ No original: "Il appartient à l'arbitre, avant d'accepter sa mission, de révéler toute circonstance susceptible d'affecter son indépendance ou son impartialité." A redação aparenta ser um avanço frente à redação antiga, constante do art. 1.452, al. 2, no qual se lia que "[l]'arbitre qui suppose en sa une cause de récusation doit en informer les parties". Code de Procédure Civile, disponível no endereço eletrônico http://www.legifrance.gouv.fr/affichCode.do;jsessionid=AFF74D5E43A870DC86EC846458FDDA6D.tpdjo $07 \mathrm{v} \_3$ ?idSectionTA=LEGISCTA000023450938\&cidTexte $=$ LEGITEXT000006070716\&dateTexte $=2013020$ 1; consulta em 21.02.2014.
} 
o art. $14, \S 1^{\circ}$, da LA, com o detalhe desta última fazer menção a "dúvidas justificadas" quanto à independência e imparcialidade do árbitro. O Federal Arbitration Act norteamericano não prevê o dever de revelação, lacuna que é preenchida pelo regramento das instituições arbitrais; do mesmo modo, o Arbitration Act 1996 inglês prevê o dever de atuar com retidão e imparcialidade ${ }^{588}$, o dever de condução adequada do procedimento ${ }^{589} \mathrm{e}$ o dever de evitar despesas ou atrasos desnecessários ${ }^{590}$, mas nada diz sobre o dever de revelação, razão pela qual a High Court o classificou como obrigação contratual quando assim estabelecida na relação entre partes e árbitro ${ }^{591}$.

Apesar de constituir um mecanismo eficiente em teoria, fato é que, na prática, o exercício do dever de revelação enseja uma série de problemas, a começar pela inexistência de incentivo direto para que o árbitro o exerça. Efetivamente, o árbitro enfrenta um dilema no que diz respeito ao tema: revelar informações pode significar a perda do posto de árbitro (e a consequente perda de remuneração), ao passo que não revelar significa, à primeira vista, a obtenção desse posto ${ }^{592}$. Porém, a possível descoberta da informação não revelada ensejará, em um segundo momento, um procedimento de impugnação do árbitro movido ou ação de anulação da sentença arbitral instauradas por uma das partes, com a consequente perda relevante do capital simbólico do profissional.

Não se cogitando da intenção deliberada do árbitro em ocultar informações, o dilema ao qual ele se expõe serve de incentivo para que ele não revele as informações que, aos seus olhos, seriam irrelevantes para configurar a aparência de parcialidade. O problema é que o árbitro, interessado que está em sua própria nomeação, tenderá a considerar irrelevantes informações que as partes (ou ao menos a parte adversária daquela que o indicou) poderão

587 Texto disponível em inglês no endereço eletrônico http://www.gesetze-im-
internet.de/englisch_zpo/englisch_zpo.html; consulta em 21.02.2014.

588 Section 33(1)(a). Arbitration Act 1996; disponível no endereço eletrônico http://www.legislation.gov.uk/ukpga/1996/23/contents; consulta em 21.02.2014.

${ }^{589}$ Section $24(1)(d)(i)$. Idem.

${ }^{590}$ Section 33(1)(b). Ibidem.

${ }^{591}$ A caracterização contratual do "duty of disclosure", por conta da sua previsão no regulamento da CCI, é feita sobretudo nos parágrafos 26 e 32(ii) da decisão do caso AT\&T Corporation v Saudi Cable Co [2000] APP.L.R. 05/15, referido nas notas de rodapé $n^{\circ}$ s 140 e 141.

${ }^{592}$ Assim: "One of the most dramatic, if systematically obscured, ironies about arbitrators is that when they are required to self-diagnose a conflict problem, they are necessarily required to act against their own financial interest." CATHERINE A. ROGERS. Regulating... op. cit., p. 71. 
julgar importantes por ensejarem, aos seus olhos, aparência de parcialidade. Essa dissonância cognitiva é a causa de uma série de impugnações.

De fato, inúmeros são os problemas para a eleição das informações importantes de se revelar. A partir de qual ponto eventuais relações e circunstâncias que envolvem o árbitro ganham relevância a ponto de ensejarem "dúvidas justificadas"? Existiria um limite temporal a partir do qual tais relações e circunstâncias perderiam relevância? O árbitro deve efetuar pesquisa para levantar essas relações e circunstâncias ou deve revelar apenas o que sabe? Qual é a consequência da violação do dever de revelação? Essas e outras questões serão examinadas a seguir, nos limites em que importam para o objeto do presente estudo, qual seja, o exame da imparcialidade do árbitro.

\subsubsection{Natureza e conteúdo do dever de revelação}

O presente estudo defende que a imparcialidade do árbitro deriva do próprio modelo processual democrático ${ }^{593}$. É um dever que nasce em razão do processo e para o processo, assumido a partir do momento em que o profissional é alçado à função de julgador e mantido até o encerramento do procedimento. Há casos em que eventos posteriores ao fim do processo arbitral denotaram a aparência de parcialidade do árbitro; no entanto, embora tenham ocorrido após o término do procedimento, tais eventos demonstraram que o ataque à imparcialidade ocorreu no curso do processo arbitral: é o caso do árbitro que (não revelou que) seria contratado pelo requerido no dia seguinte à prolação da sentença $\operatorname{arbitral}^{594}$. Igualmente, eventos anteriores ao início do processo arbitral podem protrair efeitos sobre a aparência: é o caso do árbitro que pertencia, até o dia anterior à sua nomeação, ao escritório de advocacia de uma das partes. O evento concreto (contrato do árbitro com o escritório) está findo, mas ainda assim preenche os critérios relativos às premissas de estrutura e de conteúdo que dão pela aparência de parcialidade do árbitro ${ }^{595}$.

\footnotetext{
${ }^{593}$ Vide capítulo 2.2.1 do presente estudo.

${ }^{594}$ Caso Raoul Duval v. Merkuria Sucden, referido por PEDRO SOUSA UvA. A comparative reflection on challenge of arbitral awards through the lens of the arbitrator's duty of impartiality and independence, in American reviewof international arbitration, v. 20, p. 500. Em sentido análogo, vide o já referido caso $K P M G A B$ v. ProfilGruppen $A B$, referido nas pp. 34-35 do presente estudo.

${ }^{595}$ Sobre o tema, vide capítulo 3.4.4 do presente estudo.
} 
A seu turno, o dever de revelação não deriva do modelo processual, servindo-o apenas na medida em que possibilita o afastamento de árbitro envolvido em eventos que ensejem a aparência de parcialidade. Também diferentemente do dever de imparcialidade, que tem natureza processual, o dever de revelação é orientado pela sua natureza contratual ${ }^{596}$, ou seja, está ligado ao contrato de arbitragem estabelecido entre partes e árbitro (com ou sem a participação de uma instituição arbitral), e não ao processo em si ${ }^{597}$. A anterioridade do dever de revelação é tamanha frente à instauração do processo que pode recair em profissionais com quem o contrato de arbitragem não chegue sequer a ser firmado. A qualificação de pré-contratual parece mais exata: o dever existe por conta de um contrato a ser celebrado (o contrato de arbitragem), mas é eficaz antes da sua celebração, assim permanecendo durante todo o curso da relação contratual.

Mais importante que a diferente natureza é a diferença de conteúdo entre o dever de imparcialidade e o dever de revelação. O primeiro consiste no dever de o árbitro não se fechar à influência potencialmente exercida pelos argumentos das partes, verificável mediante a apreciação de eventos que ensejam a aparência de vedação psíquica do árbitro à luz de premissas de estrutura e de conteúdo avaliadas por um observador desinteressado. O segundo consiste no dever de o árbitro revelar circunstâncias que, aos olhos das partes, que são observadores interessados (ou mesmo desconfiados quanto ao árbitro nomeado pelo seu adversário), poderiam ensejar dúvidas justificadas a respeito da parcialidade.

\footnotetext{
${ }^{596}$ O fato de a LA impor o dever de informação não altera sua natureza contratual, sendo desnecessário para a finalidade do presente estudo o exame da existência ou não de distinção entre os deveres acessórios (que somente existem em função de uma relação obrigacional) e os deveres gerais de conduta (que antecedem e conformam a relação obrigacional), bem como suas respectivas naturezas. Tratando-se de ingerência estatal na autonomia privada, basta apontar que a função do dever de informação volta-se ao cumprimento da obrigação principal do contrato de arbitragem, separando-o da relação jurídica processual. Sobre os deveres acessórios no direito brasileiro, vide a seminal obra de Clóvis do Couto e Silva, escrita em 1964 e reeditada nos anos 2000 (CLÓVIS do CoUTO E SILVA. A obrigação como processo. Rio de Janeiro: Editora FGV, 2007 , pp. 91-97) e, mais atualmente, em observação aos deveres pré-contratuais, entre eles o de informação, vide JUDITH MARTINS-COSTA. Um aspecto da obrigação de indenizar: notas para uma sistematização dos deveres pré-negociais de proteção no direito civil brasileiro, in Revista dos Tribunais, v. 867, Separata, 2011, pp. 37-49.

${ }^{597}$ A existência de um contrato de arbitragem - e o lançamento de seus efeitos sobre a relação contratual é tratada por PHILliPE FouchARD. Les rapports entre l'arbitre et les parties et l'institution arbitrale, in Bulletin de la Cour Internationale d'Arbitrage de la CCI: 1995 Supplement Special - Le statut de l'arbitres. Paris: ICC Publishing, p. 16. No Brasil, a lição de que as partes podem modular os poderes jurisdicionais dos árbitros pelo "contrato de arbitragem" foi apresentada por IRINEU STRENGER. Arbitragem comercial internacional. São Paulo: LTR, 1996, pp. 67-68.
} 
É de se notar que a mudança de observador, tomada de modo isolado, amplia enormemente o rol de eventos reveláveis, visto que um observador interessado desconfiará de eventos que não importariam a um observador isento; no entanto, também se deve notar que somente integram o rol de eventos reveláveis aqueles que ensejarem dúvidas justificadas nesse observador. Assim, a ampliação resultante da mudança do observador é temperada com a exigência de justificativa para a dúvida que o evento ensejaria quanto à parcialidade do árbitro ${ }^{598}$.

Concretamente, esses fatores ampliam as causas de revelação frente às categorias de aparência de parcialidade ${ }^{599}$ ou, melhor dizendo, a verificação dessas mesmas categorias com critérios mais rígidos de avaliação, exatamente para se buscar a dúvida razoável ou justificada do observador interessado. No entanto, contatos e relações triviais sem significação pessoal ou econômica (e, portanto, não ensejadores de dúvidas razoáveis ou justificadas) devem continuar a ser ignorados ${ }^{600}$. É o caso, por exemplo, da contribuição regular do árbitro presidente na revista científica de cujo conselho editorial o coárbitro fazia parte, fato esse que, segundo a Corte de Apelação de Paris, não ensejaria dúvida justificada quanto à imparcialidade dos julgadores nem criaria vínculo intelectual ou pecuniário entre eles ${ }^{601}$.

O dever de revelação não se circunscreve apenas aos eventos dos quais o árbitro tem conhecimento, mas também daqueles que ele, razoavelmente, poderia conhecer. Significa dizer que o dever de revelação compreende o dever de investigar. Para desimcumbir-se do dever de revelação, o árbitro deve perquirir a respeito de todas as potenciais causas de

\footnotetext{
${ }^{598}$ Literalmente: "L'arbitre doit reveler toutes les circonstances de nature à provoquer dans l'esprit des parties un doute rasonnable sur sont independence, et notamment es informer de toute relation que ne présente pas un caractère notoire et qui pourrait raisonnablement avoir à leur yeux une incidence sur son jugement." No caso, dois dos árbitros não revelaram que pertenciam ao comitê científico de uma revista científica e à direção editorial de outra.Trata-se do caso SA Sorbrior et autres v. SAS ITM Entreprises et autres (CA Paris, 01.07. 2011), in Revue de l'arbitrage, 2011, pp. 839-841.

${ }^{599}$ Vide capítulo 3.4 do presente estudo. Em comentário às IBA Guidelines, Brower observa que " $[t] o$ balance the 'eyes of the parties' test and prevent both strategic challenges and unnecessary disclosures (which then can stimulate undue concerns of bias in parties' minds), the IBA Guidelines emphasize that disclosure based on subjective grounds should not lead to automatic disqualification". CHARLES N. BROWER. The Ethics... op. cit., p. 12.

${ }^{600}$ TRAVIS JACOBS. Arbitrator or private investigator: should the arbitrator's duty to disclose include a duty to investigate?, in Journal of dispute resolution, 1997, n. 1, p. 137.

${ }^{601}$ Caso Emivir, Loniewski, Gauthier v. ITM, referido por DOMINIQUE HASCHER. Independence and impartiality of arbitrators: 3 issues, in American University international law review, v. 27, 2011-2012 , p. 798.
} 
conflito de interesses (aos olhos das partes, seja lembrado), verificando não só sua lista de clientes e frente a quem seus serviços foram prestados ${ }^{602}$, seus contatos profissionais (em especial, os escritórios e advogados com os quais o árbitro ou seu escritório mantêm relação negocial ou parceria), acadêmicos e pessoais, seus investimentos (ampliando essa pesquisa para todos os familiares que com ele residam ou mantenham contato próximo), como também mesmo realizando pesquisas por palavras nos sistemas e nos documentos digitais do seu escritório, tudo a fim de eliminar qualquer possibilidade de ter se envolvido em evento ensejador de dúvidas justificadas aos olhos das partes a respeito da sua imparcialidade $^{603}$. Quando o processo arbitral envolver grandes empresas, deve o árbitro solicitar às partes mais informações sobre seus sócios e sociedades coligadas, realizando novamente toda a averiguação frente a esses sujeitos.Mais: o dever de revelação inclui as relações do árbitro com os demais membros do painel ${ }^{604}$.

A orientação jurisprudencial é clara no sentido de reconhecer o dever de investigar ${ }^{605}$, também registrada nas IBA Guidelines, que atribuem ao árbitro o dever de "realizar diligências razoáveis no sentido de averiguar qualquer potencial conflito de interesses”, reconhecendo, ainda, que o “desconhecimento não serve de justificativa para a não divulgação de um potencial conflito se o árbitro não tiver realizado uma razoável tentativa de investigação" 606 .

Pela própria dinâmica das relações sociais, é reconhecido um limite temporal a partir do qual os eventos deixam de ensejar dúvidas justificadas sobre a imparcialidade do árbitro e, portanto, não precisam ser revelados. No entanto, não há consenso sobre quanto tempo

\footnotetext{
${ }^{602}$ Às vezes, a dúvida sobre a imparcialidade não se dá em razão do cliente do árbitro, mas sim em razão da entidade frente a qual esse serviço é prestado, tal como a contraparte em processo ou em contrato.

${ }^{603}$ Nesse sentido: "Since an arbitrator acts in a quasi-judicial capacity, his or her conflict check should include an investigation into categories such as: any relationship between the arbitrator and the parties; any past or present dealings between the arbitrator and the parties' attorneys; any financial, social, or professional affiliation / interest between the arbitrator and a party or attorney in the arbitration; and any relationship or interest between the arbitrator's family members and the parties or the parties' attorneys to the dispute". KATHRYN A. WINDSOR. Defining arbitrator evident partiality: the catch-22 of commercial litigation disputes, in Seton Hall Circuit review, v. 6, n. 1, 2009, p. 215.

${ }^{604}$ É o que recomendam, entre outras informações, que o árbitro revele, JULIAN D. M. LEW; LOUKAS A. Mistelis; STEFAN MiCHAEL KRÖLL. Comparative international commercial arbitration. The Hague: Kluwer Law International, 2003, p. 266.

${ }^{605}$ Vide caso Schmitz v. Zilvetti, referido na p. 123 do presente estudo. Na jurisprudência francesa, vide o amplo estudo de MARC HENRY. Le devoir de revelation dans les rapports entre arbitras et conseils: de la suggestion aux électrochocs, in Les cahiers de l'arbitrage, 2011, n. 3, p. 788-795.

${ }^{606}$ Ambos os trechos entre aspas compõem o Princípio Geral 7(c).
} 
esse limite representaria. Seriam dois anos, dez, vinte? Na ausência de determinação vinculante, o árbitro pode se nortear pelo limite de três anos recomendado em vários itens das Listas de Aplicação das IBA Guidelines ${ }^{607}$, embora não seja incomum que profissionais que figuram como árbitros, buscando ensejar mais confiança em sua nomeação (e assim incrementar seu capital simbólico) estendam esse prazo até cinco anos ${ }^{608}$.

Outro tema ligado ao conteúdo do dever de revelação é o tratamento que deve ser dispensado às informações de domínio público. Não se pode negar que o dever de revelação impõe ao árbitro informar tudo o que saiba (e proceder à pesquisa razoável daquilo que não saiba) ser capaz de ensejar dúvidas justificadas ou razoáveis quanto à sua imparcialidade, correspondendo a esse dever o direito das partes de ser informadas. Esse direito, como já se viu, tem como função municiar as partes de informações para que se cuide - antes ou durante o curso do processo arbitral - da higidez desse processo, impedindo que profissionais envolvidos em eventos que ensejem aparência de parcialidade assumam ou exerçam o encargo de árbitro.

Não obstante a clara função profilática do dever (e do correspondente direito) de revelação, não é incomum constatar a prática de se requerer a anulação da sentença arbitral, com base na alegação de que esse dever não teria sido corretamente observado em razão da não prestação, pelo árbitro, de informação de domínio público. A manobra é clara: a parte, conhecendo a informação, não a invoca no curso do processo arbitral, guardando-a para dela se utilizar apenas no caso de derrota ${ }^{609}$. Assim, um direito cuja função é patrocinar a higidez do processo (e, portanto, a segurança jurídica) acaba por ser utilizado para conferir ao derrotado uma segunda chance de vitória (em atentado à segurança jurídica). Esse desvio de função é manobra característica do abuso de direito ${ }^{610}$.

\footnotetext{
${ }^{607}$ Notadamente os itens 3.1.1 a 3.1.5, 3.3.3, 3.4.2 e 3.4.4.

${ }^{608}$ Reconhecendo aplicar um prazo arbitrário de cinco anos, pois um prazo maior ensejaria maior dificuldade - e maior chance de falhas - na investigação, GERALD AKSEN, The tribunal's appointment, in LAWRENCE W. NEWMAN; RICHARD D. HILl (Ed.). The leading arbitrators' guide to international arbitration. 2. ed. New York: Juris Publishing, 2008, p. 34.

${ }^{609} \mathrm{Na}$ tentativa de coibir essa prática, o Princípio Geral 7(b) das IBA Guidelines recomenda que a parte apresente informação que lhe seja disponível e que realize uma busca razoável de informação de domínio público.

${ }^{610}$ Conforme art. 187 do Código Civil: "Também comete ato ilícito o titular de um direito que, ao exercê-lo, excede manifestamente os limites impostos pelo seu fim econômico ou social, pela boa-fé ou pelos bons costumes."
} 
Evidentemente, a informação omitida pelo árbitro deve ser pública e acessível às partes (não somente aos seus advogados), o que significa dizer que não deve oferecer maiores dificuldades para ser encontrada, mesmo para o leigo. Obter a informação de que o árbitro e o advogado de uma das partes são professores regulares de uma mesma universidade é relativamente simples, bastando conferir o currículo de ambos na internet e procurar seus nomes no endereço eletrônico da universidade; obter a informação de que esses mesmos profissionais trabalham juntos por conta de uma comissão nomeada por um município (ainda que a nomeação de ambos tenha sido publicada no diário oficial) já é muito mais difícil, sendo mais escusável que a parte não tenha conhecimento dela.

Assim, para que se caracterize o abuso no direito de revelação pela parte (o que não significa dispensa do dever de revelação pelo árbitro), a informação deve ser pública e acessível, tal como se verificou no caso Nidera v. Leplatre, no qual a Corte de Apelação afastou como causa de anulação de sentença arbitral a não revelação, pelo árbitro, de que ele era presidente de uma associação profissional da qual uma das partes era associada. A Corte de Apelação considerou que essa situação era conhecida por todos os envolvidos no mercado agrícola (explorado pelas partes), observando, ainda, que a associação continha mais de oitocentos membros ${ }^{611}$.

Por fim, necessário apontar que o dever de revelação se mantém eficaz durante todo o curso do processo arbitral. O árbitro deve, assim, continuar a perquirir e informar as partes sobre quaisquer eventos - mesmo os ocorridos após a assunção do encargo - que possam gerar dúvidas razoáveis ou justificadas quanto à sua imparcialidade. É o que fica claro no caso J\&P Avax v. Société Tecnimont, no qual o árbitro presidente em processo CCI revelou, em declaração de independência, que era of-counsel de um escritório localizado em Paris, cujas filiais de Washington DC e Milão haviam prestado serviços a sociedades coligadas da Tecnimont, dos quais o árbitro não havia participado. No curso do processo, a Avax tomou conhecimento de que o referido escritório prestava serviços a companhia que foi posteriormente adquirida por uma coligada da Tecnimont, razão pela qual impugnou o árbitro na CCI, sem sucesso. Com a prolação de sentença parcial, a Avax pleitou judicialmente a sua anulação, pedido provido pela Corte de Apelação de Paris em 12 de fevereiro de 2009, sob a conclusão de que o dever de revelação do árbitro é contínuo. A

${ }^{611}$ Caso Nidera France v. Société Leplatre (C.A. Paris 16.12.2010), in Revue de l'arbitrage, 2011, p. 279. 
Corte de Cassação anulou a decisão por entender que o julgamento da Corte de Apelação de Paris não havia se restringido aos fatos e argumentos apresentados pelas partes, remetendo a causa para a Corte de Apelação de Reims. Em 2 de novembro de 2011, essa Corte anulou a sentença parcial por falta de revelação de conflito de interesse no curso da arbitragem. ${ }^{612}$.

\subsubsection{Violação do dever de revelação não dá causa, per se, à parcialidade do árbitro}

O dever de revelação não se confunde com a imparcialidade, nem o seu descumprimento não leva, ipso facto, à nulidade do processo arbitral.

Ao analisar a jurisprudência inglesa e francesa anterior a 2009, a doutrina reconheceu que é a violação da imparcialidade a causa de anulação de sentença arbitral, consistindo a violação do dever de revelação apenas mais um elemento de apreciação, entre outros, que pode levar à aparência de parcialidade ${ }^{613}$, não devendo configurar causa direta de anulação de sentença arbitral ${ }^{614}$.

Na Inglaterra, os casos $A T \& T^{615}$ e Laker Airways ${ }^{616}$ apartam o dever de revelação (não previsto no Arbitration Act) da imparcialidade, demonstrando que "full disclosure means

612 A decisão da Corte de Paris pode ser consultada no endereço eletrônico http://www.ohada.com/content/newsletters/1334/Arret-Avax-Tecnimont-CApp-Reims-2-novembre-

2011.pdf; consulta em 21.02.2014; a decisão da Corte de Reims pode ser consultada no endereço eletrônico http://arbitragem.pt/jurisprudencia/arbitragem-estrangeira/2011-11-02--acordao-da-cour-d-appel-de-

reims.pdf; consulta em 21.02.2014. Considerações sobre o caso e suas implicações na jurisprudência francesa relativa ao dever de revelação podem ser consultadas no endereço eletrônico http://kluwerarbitrationblog.com/blog/2011/11/25/tecnimont-the-saga-continues-but-is-not-yet-over/; consulta em 21.02.2014.

${ }^{613}$ JEAN-FranÇOIS POUdRET; SÉBASTIEN BESSON. Comparative law of international arbitration, London: Sweet \& Maxwell, 2007, p. 361.

${ }^{614}$ MARC HENRY. Le devoir de revelation ... op. cit., p. 789. Contra, afirmando que o dever de independência (imparcialidade) dissolveu-se no dever de revelação, THOMAS ClAY. Note sous CA Paris, 18 décembre 2008, in Revue de l'arbitrage, 2009, n. 1, p. 196.

${ }^{615}$ Vide notas de rodapé $\mathrm{n}^{\mathrm{os}} 140$ e 141.

${ }^{616}$ Vide notas de rodapé $\mathrm{n}^{\text {os }} 138$ e 139. 
the fullest possible disclosure ${ }^{, 617}$ e que o descumprimento daquele dever não enseja, por si, a parcialidade do árbitro.

Na França, além dos já tratados casos Tecso v. Neoelectra Group e $J \& P$ Avax v. Société Tecnimond, que denotam bastante rigor na avaliação do dever de informação ${ }^{618}$, são registrados outros casos em que o descumprimento do dever de revelação serviu, diante de circunstâncias específicas ou outras informações, para qualificar a parcialidade do árbitro. No caso Allaire v. SGS Holdings, a primeira alegou, no curso do procedimento arbitral, que o árbitro indicado pela SGS, Nicolas Molfessis, era consultor do advogado desta. O coárbitro respondeu, afirmando que efetivamente prestava serviços para o escritório do patrono da SGS, mas que desde o início da arbitragem havia interrompido a consultoria. Recusou-se, no entanto, a revelar qualquer informação relativa ao montante recebido pelos trabalhos realizados. Levada a questão à Corte de Apelação de Paris, esta considerou que a relação do árbitro com o escritório de advocacia não era ocasional nem havia ocorrido em passado distante, gerando dúvidas justificadas quanto à parcialidade, especialmente diante da recusa do árbitro em fornecer maiores informações sobre a remuneração envolvida ${ }^{619}$. No caso Nykcool v. Dole France et Agrunord, nenhum dos membros do tribunal arbitral apresentou qualquer declaração a respeito da sua independência, mesmo após instados pelo requerente. O presidente do tribunal, em nome de todos os árbitros, apenas lamentou a atitude desconfiada do requerente. Levada a questão ao Poder Judiciário, este considerou que a recusa dos árbitros em revelar eventuais relações com as partes - especialmente diante do fato de que o árbitro nomeado pelos requeridos estava envolvido em outro

\footnotetext{
${ }^{617}$ LAURENCE SHORE. Disclosure and impartiality: an arbitrator's responsability vis-a-vis legal standards, in Dispute resolution journal, v. 57, n. 1, 2002, p. 35. Extensos comentários a decisões inglesas e norteamericanas relativas ao tema são feitos pelo autor.

${ }^{618}$ Nesses casos, um rigor excessivo segundo TOM PhILIPPE HeINTZ; Gustavo VIEIRA DA Costa CERQUEIRA. Racionalização... op. cit., pp. 411-434.

${ }^{619}$ Decisão anotada por PHILIPPE PINSOLle. Note sur l'arrêt de la Cour d'appel de Paris du 9 septembre 2010 (Consorts d'Allaire c/. SAS SGS Holding France), in ASA Bulletin, v. 29, 2011, pp. 198-204. Críticas à decisão, pelo fato de a Corte não ter levado em consideração que o advogado da requerente já conhecia, antes da instauração da arbitragem, o trabalho do árbitro como parecerista, tendo inclusive recebido um parecer dado por Molfessis no interesse do escritório que patrocinava a requerida (para outro cliente desse escritório e em outro caso), são movidas por SOPHIE SALGUEIRO. A independência e a imparcialidade do árbitro à luz da jurisprudência da Corte de Apelação de Paris confrontada à prática brasileira, in Revista de arbitragem e mediação, v. 32, 2012, esp. pp. 380.
} 
procedimento arbitral com os requeridos - levantava dúvidas razoáveis sobre a independência e imparcialidade do árbitro ${ }^{620}$.

Análise feita da jurisprudência norte-americana ${ }^{621}$ também afasta o descumprimento do dever de revelação como causa suficiente para a anulação da sentença arbitral e também considera que tal descumprimento pode, de acordo com as circunstâncias, aparentar a parcialidade do árbitro - e ser evento hábil a invalidar a decisão ${ }^{622} 623$. Referida aparência, no entanto, pode ser afastada mediante provas. Foi o que ocorreu no caso Drinane v. State Farm, no qual os autores, vencedores em parte em processo arbitral movido na AAA contra a companhia seguradora, moveram ação para anulação da sentença por terem posteriormente descoberto que o árbitro único escolhido pelas partes, Steven E.Yonover, representava clientes em outra demanda contra a State Farm (naquele processo assim como na arbitragem representados pelo escritório Querrey and Harrow). Restou demonstrado que: $(i)$ a equipe do escritório que patrocinou a State Farm no caso em que Yonover atuou como árbitro não foi a mesma que trabalhou no caso em que ele atuou como advogado; e (ii) a equipe de Yonover que subsidiou sua atuação como árbitro não foi a mesma que patrocinou a causa em que ele foi advogado. Foi demonstrado, ainda, que não houve comunicação entre as diferentes equipes no âmbito de cada escritório ${ }^{624}$. Com equipes distintas atuando em ambos os escritórios, eliminou-se a possibilidade de que o árbitro viesse a tomar conhecimento de fatos relativos à causa que deveria decidir por outro meio que não as manifestações das partes na arbitragem. Não fosse essa demonstração, " $[t] h e$ potential for improper communication between these entities [State Farm and Querrey and Harrow] and Yonover is sufficient to create the presumption [of bias]". Assim, embora a Suprema Corte de Illinois tenha reconhecido que Yonover tivesse o dever de revelar sua

\footnotetext{
${ }^{620}$ Caso Nykcool v Dole France et Agrunord et al. referido por DOMINIQUE HASCHER. Independence... op. cit., p. 799.

${ }^{621}$ MERRICK T. RosSEIN; JENNIFER HoPE. Disclosure... op. cit., p. 215.

${ }^{622}$ ALAN SCOTT RAU. Integrity... op. cit., p. 492.

623 "The material and relevant facts an arbitrator fails to disclose may demonstrate his 'evident partiality' under 9 U.S.C. \& 1O(a)(2). However, nondisclosure, even of such facts, has no independent legal significance and does not in itself constitute grounds for vacating an award". Caso ANR Coal Co. v Cogentrix of N.C. Inc., 173 F.3d 493 (4th Cir. 1999). Decisão disponível no endereço eletrônico http://openjurist.org/173/f3d/493/anr-coal-company-incorporated-v-cogentrix-of-north-carolina-incorporated; consulta em 21.02.2014.

${ }^{624}$ Caso Thomas Drinane et al. v. State Farm Mutual Automobile Insurance Company, 606 N.E.2d 1181 (IIl. 1992), disponível no endereço eletrônico http://www.leagle.com/decision/19921787606NE2d1181_11648; consulta em 21.02.2014.
} 
relação com a State Farm e Querrey and Harrow, essa violação não foi suficiente, à luz das demonstrações feitas, para ensejar a aplicação da Section 10 da FAA.

No caso Suez v. Argentina, processo arbitral que seguiu as regras ICSID, um segundo fundamento para a impugnação da árbitra Gabrielle Kaufmann-Kohler foi a não revelação, por parte desta, do seu relacionamento com o UBS, sócio de companhias que figuravam como parte ${ }^{625}$. Os árbitros que decidiram o incidente, apoiados na interpretação da doutrina relativa às regras UNCITRAL ${ }^{626}$, apontaram que o descumprimento do dever de revelação não levaria ao afastamento automático de um árbitro, mas sim poderia ser interpretado como suficiente para levantar dúvidas sobre a imparcialidade desse árbitro se a não revelação fosse intencional - e não o resultado de um juízo discricionário e honesto ${ }^{627}$.

No caso ICSID Alpha v. Ukraine, a segunda impugnou o árbitro nomeado pela primeira, Yoram Turbowicz, porque o profissional não teria revelado ter sido aluno da Universidade de Harvard nos anos 1980, juntamente com o advogado da Alpha, Leopold Specht. Os árbitros que decidiram a impugnação deram pelo seu não provimento ao observarem que (i) os padrões do dever de revelação impostos pelo art. 6(2) do Regulamento ICSID são mais amplos que os padrões para a avaliação da imparcialidade nos termos dos artigos $14 \mathrm{e}$ 57 da Convenção ICSID; (ii) o descumprimento do dever de revelação, por si só, não é suficiente para tornar um árbitro parcial; (iii) o árbitro pode ser considerado parcial se o fato não revelado for grave o suficiente para indicar a manifesta impossibilidade de o julgador proceder a um julgamento imparcial; e (iv) se o fato não apontar, por si só, a impossibilidade de um julgamento imparcial, a sua ocorrência em conjunção com a não revelação podem ensejar a conclusão no sentido da desqualificação do árbitro ${ }^{628}$.

\footnotetext{
${ }^{625}$ Vide p. 112 do presente estudo.

${ }^{626}$ Sobre a interpretação das regras UNCITRAL e a consideração de que a violação do dever de revelação não enseja, por si, dúvidas justificadas sobre a imparcialidade do árbitro nem sua desqualificação, DAVID D. CARON; LEE M. CAPLAN; MATTI PELlONPAA. The UNCITRAL arbitration rules: a commentary, New York: Oxford University Press, 2006, p. 197. No mesmo sentido para as regras CCI, W. LAWRENCE CRAIG; WILLIAM W. PARK; JAN PAULSSON. International... op. cit., p. 215.

${ }^{627}$ Decision on a Second Proposal for the Disqualification of a Member of the Arbitral Tribunal, proferida para os casos ICSID Case $n^{o} A R B / 03 / 19$ (Vivendi) e ICSID Case $n^{o}$ ARB/03/17 (Suez), referida na nota de rodapé $\mathrm{n}^{\circ} 361$.

${ }^{628}$ Decision on Respondent's Proposal to Disqualify Arbitrator Dr. Yoram Turbowicz, proferida no caso Alpha Projektholding GMBH v. Ukraine (ICSID Case No. ARB/07/16), disponível no endereço eletrônico http://italaw.com/sites/default/files/case-documents/ita0025.pdf; consulta em 21.02.2014.
} 
A doutrina brasileira também afasta a violação do dever de revelação como causa direta e suficiente de parcialidade do árbitro ${ }^{629}$.

Sobre a técnica e o momento de impugnar o árbitro quanto à violação do dever de revelação, anota a doutrina - com base no que ocorre na prática - que quanto antes a impugnação for feita, mais confortável será para que a instituição arbitral mova-se no sentido de evitar qualquer problema concernente à higidez do processo e da sentença, afastando o árbitro, ainda que não haja causa pungente para se concluir a respeito da sua parcialidade; por outro lado, se a impugnação for feita após a audiência, o afastamento é muito menos provável, e muito mais severa deverá ser a causa de impugnação, além de existir risco de preclusão à oportunidade de apresentar a alegação e o correspondente requerimento ${ }^{630}$.

\subsection{Imparcialidade e binômio ciência-aceitação}

Constituindo fenômeno que tem raiz na autonomia da vontade, a arbitragem permite que muitas de suas características - respeitados os limites do devido processo ${ }^{631}$ - sejam moduladas pelas partes. Com a imparcialidade do árbitro ocorre o mesmo.

\footnotetext{
${ }^{629}$ Nesse sentido, três pareceres sobre o mesmo caso, que envolvia questão a respeito da extensão do dever de revelação do árbitro - um deles divergente frente aos demais quanto ao mérito, mas todos conformes quanto à estrutura desse dever - foram publicados em uma mesma edição da Revista de Arbitragem. São eles: Luiz Olavo BaPtista. Dever de revelação do árbitro: extensão e conteúdo. Inexistência de infração. Impossibilidade de anulação da sentença arbitral, in Revista de Arbitragem e Mediação, v. 36, 2013, pp. 199-217; Pedro A. Batista Martins. Dever de revelar do árbitro, in Revista de Arbitragem e Mediação, v. 36, 2013, pp. 219-229; e SELMA MARIA FERREIRA LEMES. O dever de revelação do árbitro, o conceito de dúvida justificada quanto a sua independência e imparcialidade) art. 14, § 1 1, da Lei 9.307/1996) e a ação de nulidade de sentença arbitral (art. 32, II, da Lei 9.307/1996), in Revista de Arbitragem e Mediação, v. 36, 2013, pp. 231-251.

${ }^{630}$ Nesse sentido, ALAN SCOTT RAU. Integrity ... op. cit., p. 490. Sobre o mesmo fenômeno, com foco na CCI, apontando que os custos e o desperdício de tempo para o afastamento do árbitro e recomposição do tribunal arbitral são de grande magnitude, vide STEPHEN BOND. The experience of the ICC in the confirmation/appointment stage of an arbitration, in Northwestern journal of international law \& business, v. 12, n. 1, 1991, pp. 17-18.

${ }^{631}$ Em tentativa de reconhecer o conteúdo mínimo do devido processo na arbitragem internacional, tomando como partida a Convenção de Nova Iorque e as disposições da convenção de arbitragem, vide MATTI S. KuRKela; SANTtu TURUnen. Due process... op. cit., esp. pp. 41 e 78-79. Marcos Montoro identifica quatro grupos de limites para a criação e adaptação de regras procedimentais na arbitragem: (i) bons costumes e ordem pública; (ii) contraditório, igualdade, imparcialidade e livre convencimento; (iii) regras cogentes da LA; (iv) princípios processuais derivados da Constituição. MARCOS ANDRÉ FrANCO MONTORO. Flexibilidade do procedimento arbitral, Tese apresentada como requisito para a obtenção do título de Doutor em Direito Processual na Faculdade de Direito da USP, São Paulo, 2010, pp. 134-135.
} 
Tomando conhecimento de evento que pode caracterizar a aparência de parcialidade do árbitro (seja porque previsto nas hipóteses de impedimento e suspeição do juiz ou em outro regramento aplicável, seja porque prejudicial ao estado de coisas relativo ao tema, imposto pela LA), as partes podem renunciar à faculdade de recusa ou impugnação do árbitro, sob o entendimento de que tal evento não afetaria, em concreto, a imparcialidade do árbitro. Trata-se do binômio ciência-aceitação ${ }^{632}$.

Ao aceitarem árbitro envolvido em evento que aparente parcialidade, as partes não estão a alterar a estrutura da relação processual. Ao contrário, estão apenas apontando que, no seu entendimento e para aquele caso concreto, tal evento não afetaria a imparcialidade do julgador, descartando a ligação entre a aparência que o evento ensejaria e o entendimento que dele as partes têm. A imparcialidade do julgador - que consiste na sua não vedação à influência potencial dos argumentos apresentados pelas partes - não se encontra na esfera da autonomia privada das partes, mas antes é irrenunciável, por estar ligada ao próprio modelo democrático de processo ${ }^{633}$. Colocado de outro modo, as partes elaboram norma concreta na qual o evento que conhecem deixa de desencadear as consequências previstas nas regras vinculantes para a parcialidade do árbitro (remoção do árbitro, anulação dos atos processuais e seu refazimento por tribunal composto por outro árbitro, anulação da sentença arbitral, entre outras).

O único caso concebível em que a renúncia das partes não surtiria efeitos seria aquele em que houvesse identidade total entre árbitro e parte. Isso porque, ao figurar ao mesmo tempo em posições distintas da relação jurídica processual, o julgador-parte acaba por desnaturar a própria estrutura concebida para o método heterocompositivo - que, por definição, envolve a distinção pessoal entre julgador e parte ${ }^{634}$. Não se pode confundir a identidade pessoal e total entre árbitro e parte com a hipótese em que o julgador também pertença a algum órgão da parte pessoa jurídica. Aqui, há relação do árbitro com a parte (que pode ser

\footnotetext{
${ }^{632}$ A expressão é apresentada por RAFAEL FRANCISCO ALVES. A imparcialidade... op. cit., p. 121.

${ }^{633} \mathrm{O}$ conteúdo e a operacionalização da imparcialidade, derivados do modelo democrático de processo, são tratados no capítulo 2 do presente estudo.

${ }^{634}$ Sendo árbitro e parte a mesma pessoa, cuja decisão vincula a parte adversária, o método de solução da controvérsia se afasta daquele previsto para os métodos heterocompositivos. ANTONIO CARLOS DE ARAÚJO CinTRA; AdA Pellegrini Grinover; CÂNDIDO RANGel Dinamarco. Teoria Geral... 22. ed. op. cit., p. 27.
} 
objeto do binômio ciência-aceitação), mas não a identidade pessoal e total hábil a desnaturar a estrutura da relação jurídica processual.

Esclarecidos os efeitos e limites do binômio, convém analisar mais detidamente seus dois componentes: ciência e aceitação.

Para que possam fazer um juízo que afaste a aparência de parcialidade, é certo que as partes devem conhecer - ou ao menos ter a possibilidade de conhecer - todas as circunstâncias do evento que ensejaria tal aparência. É por isso que a ciência deve se dar sobre informação com nível de detalhes suficiente para, no mínimo, possibilitar dita análise. Tome-se, por exemplo, a informação de que o árbitro "teve relação com a parte no passado", que é diferente da informação de que o árbitro "foi advogado que defendeu uma coligada da parte em processo judicial não ligado à arbitragem, não tendo com ela qualquer relação desde o ano de 2001”. Não se pode negar que a segunda versão, mais detalhada, permite que as partes façam um juízo mais embasado sobre a aparência de parcialidade do árbitro e, assim, é preferível à primeira versão. No entanto, se a parte tomou contato com a primeira versão da informação, mas nada fez para buscar - ainda que diretamente com o árbitro, via petição - maiores esclarecimentos, não é admissível que ela se utilize da sua inércia para alegar, no futuro (e caso seja vencida), que a ausência de detalhes a impediu de proceder a um juízo mais apurado sobre a imparcialidade do árbitro ${ }^{635}$. Essa é tática claramente dilatória ${ }^{636}$. O que se percebe da prática arbitral é que, diante de informações incompletas ou insuficientes, a parte requeira ao árbitro a sua complementação ${ }^{637}$.

\footnotetext{
${ }^{635}$ No caso Betzalel Schwartzman v. Yaakov Harlap, este último requereu ao Segundo Circuito a não homologação de sentença arbitral proferida em Israel. A disputa surgiu porque o distribuidor norte-americano de esrog recusou-se a pagar certa quantia devida pela sua importação, sob a alegação de que o produtor israelense havia violado a cláusula de distribuição exclusiva ao vender o produto a terceiros. A questão foi trazida a um árbitro-clérigo israelense, que decidiu em favor do produtor. A sentença foi trazida para cumprimento nos Estados Unidos e o distribuidor resistiu ao cumprimento sob a alegação de que o árbitro não era independente, em razão de serviços prestados ao produtor para certificação kosher, era essencial para a manutenção do mercado para o produto. A Corte de Apelação do Segundo Circuito rejeitou a impugnação, por entender que o distribuidor sabia ou poderia saber que o árbitro poderia ter relação com o produtor, em razão de cláusula contratual que assim estipulava. Concluiu, assim, que "Harlap knew that Schwartzman could hire Rabbi Stern and, thus, he had the information he needed to investigate their relationship before or during the arbitration proceedings and could have easily done so, rather than waiting until after he lost his case", não tendo exercido a sua faculdade de impugnar tempestivamente. Caso Betzalel Schwartzman v. Yaakov Harlap, $\mathrm{n}^{\mathrm{o}}$ 09-1784 (2 $2^{\circ}$ Cir 2010). Decisão disponível no endereço eletrônico http://www.leagle.com/decision/in\%20fco\%2020100518127; consulta em 21.02.2014.

${ }^{636}$ Literalmente: "Although making the required disclosures is the arbitrator's responsibility, under certain circumstances it becomes a party's responsibility to investigate and question the arbitrator, move for disqualification, or otherwise assert the party's right to obtain disclosure", pois "a party who knows or has reason to believe that the arbitrators' disclosures are inadequate but remains silent, hoping for a favorable
} 
Ainda no que concerne à ciência, ela deve ser inequívoca ${ }^{638}$ (mesmo que possa ser presumida nos casos em que a informação seja pública ${ }^{639}$ ) e deve ser da parte, ainda que, na prática, seja difícil demonstrar que a ciência do advogado a respeito de determinado evento relativamente ao árbitro tenha ou não tenha sido transmitida a ela ${ }^{640}$. Essa questão, que envolve a análise de provas e presunções, escapa do objetivo do presente estudo.

A aceitação pode ocorrer de modo expresso - no qual as partes declaram que o evento que conhecem não corrompe, ao seu juízo, a imparcialidade do árbitro -, ou de modo tácito se as partes não acusarem o fato e impugnarem o árbitro na primeira oportunidade que tiverem para se manifestar no processo arbitral, consoante o art. 20 da LA. Na prática, a dificuldade de se determinar o momento no qual a parte tomou conhecimento do fato que aparenta a parcialidade do árbitro acarreta problemas na conformação da aceitação tácita. Referência seja feita às IBA Guidelines, que consideram que a aceitação não pode ocorrer nas hipóteses arroladas na Lista Vermelha de Eventos Irrenunciáveis, mas somente de forma expressa na Lista Vermelha de Eventos Renunciáveis.

arbitration award but relying on the arbitrator's inadequate disclosure as an 'insurance policy', is adopting a risky tactic". RICHARD R. MAINLAND. Full Disclosures, in Los Angeles lawyer, nov. 2011, p. 34. Disponível no endereço eletrônico http://www.lacba.org/Files/LAL/Vol34No8/2865.pdf; consulta em 21.02.2014.

${ }^{637}$ Vários são os casos em que a parte, tomando conhecimento de informação incompleta, requereu ao árbitro maiores esclarecimentos, narrados no capítulo 3.4 do presente estudo.

${ }^{638}$ Vide caso $H S M V$ v. ADI (pp. 120 e 121 do presente estudo), em que a informação que levaria à aparência de parcialidade do árbitro constava em nota final em um de muitos documentos trocados entre as partes, não sendo considerada a ciência da parte. Outro caso, em que a ciência da ligação entre árbitro e parte foi argumento para a manutenção da sentença arbitral, é o Westinghouse Electric v. NYC Transit Authority, referido na p. 113 do presente estudo.

${ }^{639}$ Sobre a publicidade da informação e o dever da parte em proceder a pesquisas sobre o árbitro, vide capítulo 4.3.1 do presente estudo.

${ }^{640}$ No caso em que se discutiu a rígida lei de arbitragem do Estado da Califórnia no que diz respeito ao dever de revelação do árbitro, o Nono Circuito considerou que o advogado - ao admitir que sabia "há um ano ou dois" que a mulher do árbitro havia sido sócia do escritório de advocacia da parte contrária - decidiu, com seu representado (Rosenfeld), não levantar a questão até a prolação da sentença, que lhes foi desfavorável. A Corte concluiu que "[f]irst, it suggests that Rosenfeld did not himself believe that the relationship rose to a level that required disclosure under any of the applicable standards. Second, it suggests that Rosenfeld may have been sand-bagging, holding his objection in reserve in the event that he did not prevail in the arbitration". Caso Dennis Johnson v. Gruma Corp., $\mathrm{n}^{\circ}$ 08-56911 (9 Cir. 2010). Decisão disponível no endereço eletrônico http://caselaw.findlaw.com/us-9th-circuit/1534963.html; consulta em 21.02.2014. 


\subsection{Os critérios para a análise da imparcialidade devem ser os mesmos para todos os membros do tribunal arbitral. A conclusão de parcialidade de um árbitro invalida a decisão unânime do tribunal arbitral.}

Tal como visto, a imparcialidade do árbitro é requisito inescapável do modelo democrático de processo e, assim, não pode ser dispensada pelas partes, nem contornada pelo princípio majoritário. Significa dizer que, não importa se o tribunal arbitral proferiu sentença unânime ou se o árbitro tido como parcial discordou da orientação da sentença (tendo proferido um voto em outro sentido), o processo arbitral e a respectivas decisões deve ser anulados. O princípio majoritário, que pode ser atribuído à instrumentalidade das formas ${ }^{641}$ concebida para o método de solução de controvérsias oferecido pelo Estado aos seus jurisdicionados $^{642}$, deve ceder passo às exigências de legitimidade e segurança do processo arbitral, eis porque não se sabe qual a contribuição do árbitro parcial para a direção tomada pelo processo arbitral e pela sentença, que por ele podem ter sido influenciados ${ }^{643}$ ainda que seu entendimento sobre o mérito do caso tenha sido divergente ${ }^{644}$.

Isso não significa dizer que uma parte pode plantar um evento que aparente parcialidade para utilizá-lo, no futuro, como causa de anulação da sentença caso não vença a disputa. Imagine-se a parte que, em desespero de causa após uma audiência em que as testemunhas lhe foram muitíssimo desfavoráveis, procure o árbitro para expor novamente a causa, enviando-lhe um longo email com anexos documentais e deixe recados na sua secretária eletrônica. Cabendo ao árbitro dar ciência do ocorrido a todos os sujeitos do processo e abster-se de analisar as alegações, não é possível afirmar que o seu envio habilite, pela própria parte que as enviou, a possibilidade de impugnação do árbitro. Trata-se, aqui, de tática dilatória à qual não pode ser conferida qualquer efeito, além de ensejar a aplicação da penalidade prevista no art. 27 da LA. Não trata o exemplo de aplicação da

\footnotetext{
${ }^{641}$ Apontando que a técnica processual é apenas um método de trabalho, cuja função é conferir segurança e oportunidade de participação dos sujeitos no processo, bem como buscar, pela tutela jurisdicional, resposta idêntica ao cumprimento espontâneo da regra de direito material violada, razão pela qual essa busca da efetividade suportaria a superação do formalismo, vide JOSÉ ROBERTO DOS SANTOS BEDAQUE. Efetividade do processo e técnica processual. São Paulo: Malheiros, 2006, esp. pp. 75-93.

${ }^{642}$ Por essa razão, o raciocínio que permite que se afirme, como faz o STJ, que "[a] participação de Ministro impedido em julgamento em órgão colegiado não anula o julgado se o seu voto não tiver sido decisivo para o resultado" não encontra respaldo no processo arbitral. STJ, EREsp 1008792/RJ, 2ª T, Rel. Min. Nancy Andrighi, DJe 29.04.2011.

${ }^{643}$ MARCELO Roberto Ferro. Apontamentos... op. cit., p. 858.

${ }^{644}$ GARY BORN. International commercial arbitration, v. II. London: Wolters Kluwer, 2009, p. 2.614.
} 
instrumentalidade das formas, mas de vedação à obtenção de benefício pelo agente (anulação da sentença) em razão do ato torpe que cometeu (comunicação ex parte com a intenção, justamente, de criar nulidade).

Discussão ainda não superada é a aplicação do mesmo padrão de avaliação da aparência de parcialidade para os coárbitros e para o árbitro presidente. Parte da doutrina defende que, por ter sido escolhido pelas partes, a ligação dos coárbitros com elas poderia ser mais profunda que a ligação que com elas poderia ter o árbitro presidente, ensejando critérios diferentes de avaliação dos eventos que aparentariam a respectativa parcialidade ${ }^{645}$. No entanto, esse entendimento somente duplicaria a dificuldade do estabelecimento de critérios mais seguros para a solução de casos concretos: se já é extremamente difícil a avaliação dos eventos que poderiam dar causa à aparência de parcialidade do árbitro tomando-se em consideração o mesmo padrão para todos os membros do tribunal - é visível o incremento dessa dificuldade com o estabelecimento de um critério mais rígido para o árbitro presidente e de outro mais lasso para os coárbitros, bem como a abertura da possibilidade de avaliações errôneas para ambos os critérios. Assim, parece ser mais adequada a manutenção de um mesmo critério para todos os membros do tribunal $\operatorname{arbitral}^{646}$.

A eventual predisposição do árbitro à tese da parte que o nomeia, seja porque a parte pesquisou a vida e a obra do árbitro e escolheu bem, seja porque, no íntimo, o julgador pode se sentir compelido a se certificar de que os argumentos da parte que o nomeou tenham sido corretamente analisados ${ }^{647}$ (a fim de garantir novas nomeações ${ }^{648}$ ), é fator que

\footnotetext{
${ }^{645}$ YUVAL SHANY. Squaring... op. cit., p. 490. Em sentido análogo, propondo critérios mais rigorosos para o árbitro presidente e menos para os coárbitros, SAMUEL ROSS LUTTRELL. Bias... op. cit., p. 270.

${ }^{646}$ Considerando perigosas essas soluções intermediárias e apontando que a experiência arbitral inclina-se para o mesmo critério, EMMANUEl GAILlARD; JOHN SAVAGE (Ed.). Fouchard Gaillard Goldman on international arbitration, The Hague: Kluwer Law International, 1999, pp. 573-574.

647 "If arbitrators must be completely sanitized from all possible external influences on their decisions, only the most naïve or incompetent would be available." WILLIAM W. PARK. Arbitrator integrity... op. cit., p. 635.

648 "As a result of the increased competition between potential arbitrators, scholars argue that market forces may lead these arbitrators to display behavioral patterns that increase the probability of their selection in future cases." DAPHNA KAPELIUK. The repeat appointment factor: exploring decision patterns of elite investment arbitrators, in Cornell law review, v. 96, 2010, p. 80.
} 
o método de nomeação dos coárbitros pelas partes não pode superar ${ }^{649} 650$. E para que a parte conheça o árbitro, é possível que algum contato tenha sido mantido com o advogado que patrocina a causa. Isso é completamente diferente do árbitro que defende a parte que a indicou e que está inacessível à influência dos argumentos da parte contrária.

Não reconhecer o fenômeno acima referido - nem analisá-lo à luz de um conteúdo filosoficamente embasado, juridicamente defensável e faticamente realista da imparcialidade - pode levar a entendimentos ainda mais graves do que aqueles que defendem um duplo padrão de avaliação dos eventos que envolvem o árbitro. Pode levar à afirmação de que "[l'arbito di parti] potrebbe essere imparziale, ma è poco probabile - $e$ sarebbe ingenuo aspettarsi - che egli lo sia davvero" ${ }^{651}$ que, longe de ser realista, é prejudicial ao entendimento e à operação do método arbitral para a solução de controvérsias.

Assim, o presente estudo defende que o mesmo critério de avaliação das premissas de estrutura e de conteúdo deve ser aplicado a todos os membros do tribunal arbitral.

\subsection{Imparcialidade e novas fronteiras}

\subsubsection{Financiamento do litígio por terceiros}

Apesar de o financiamento de litígio por terceiros ("third party funding") ser fenômeno contratual ainda pouco regulado ${ }^{652}$, sua utilização na arbitragem é crescente, tal como se

${ }^{649}$ Sobre a discussão a respeito da influência do método de escolha dos coárbitros no posicionamento destes, vide nota de rodapé 535 .

650 Às sugestão de alteração do método de escolha dos árbitros (da nomeação direta pela parte para a indicação por uma instituição, com base ou não em uma lista) pode gerar o mal maior de favorecer ainda mais a tendenciosidade do julgador, não mais no aspecto individual (o árbitro não será tendencioso a favorecer uma ou outra parte, pois nenhuma a escolheu), mas no aspecto sistêmico ou institucional, pois a composição de uma lista de árbitros fatalmente reduzirá o pluralismo e a diversidade de entendimentos, de histórias de vida e de bagagem jurídica e cultural dos potenciais julgadores (o árbitro será tendencioso porque, tal como ele, todos ou quase todos possuem similares preconceitos e ideologia). Esse risco é mais grave para a arbitragem internacional, onde confluem sistemas político-jurídico-culturais diferentes. StAVROS BREKOULAKIS. Systemic bias and the institution of international arbitration: a new approach to arbitral decision-making, in Journal of international dispute settlement, v. 4, n. 3, 2013, esp. pp. 560 e 582.

${ }^{651}$ MiCHELE TARUFFO. Note sull 'imparzialità dell'arbitro di parte, in Rivista dell'arbitratto, 1997, p. 488.

${ }^{652}$ À exceção da Austrália, que promulgou regras para a revelação de relações de "funding" aos órgãos jurisdicionais, e do mercado de fundos da Inglaterra, que promulgou medidas de auto-regulação, não se têm 
pode inferir da frequência em que o tema ve sendo debatido em congressos e workshops; da sua crescente utilização em processos judiciais, das informações contidas no material promocional oferecido pelas empresas de "funding" (que dão conta da sua utilização na arbitragem); e da existência de diversos processos arbitrais ICSID em que a sua prática ocorreu $^{653}$.

Inexiste consenso sobre a definição do contrato, sendo que a mais ampla compreende "any financial solution offered to a party regarding the funding of proceedings in a given case". Tal definição, entretanto, é por demais vaga, a ponto de permitir a inclusão, nessa categoria, de diversas outras espécies contratuais. Outra definição, mais estrita, põe em relevância: (i) a existência de um "third party capital", ou seja, capital de entidade não ligada diretamente ao litígio (o que diferencia o fenômeno do simples acordo com o advogado, que pode oferecer uma solução financeira para parte das despesas do cliente investindo seu tempo ao invés de capital); (ii) a existência de empresas financiadoras especializadas; (iii) a dedicação dessas empresas ao financiamento de litígios e, em alguns casos, ao fornecimento de serviços para o manejo do processo, inclusive a escolha da equipe de advogados, seu pagamento e o monitoramento da sua atuação (o que diferenciam essas empresas dos "hedge funds"); e (iv) o retorno financeiro das financiadoras, que geralmente se dá em porcentagem do êxito da parte financiada ou em múltiplo do capital investido ${ }^{654}$.

A utilização desse contrato pode ocasionar diversas situações que ensejem a aparência de parcialidade do árbitro: imagine-se o árbitro que, sem contato anterior com qualquer das partes, advoga para uma outra companhia em processo não relacionado; companhia essa que, tal como uma das partes no processo arbitral, é suportada pela mesma financiadora.

notícias de outras iniciativas nesse sentido, conforme nota JENNIFER A. TRUSZ. Full disclosure? Conflicts of interest arising from third-party funding in international commercial arbitration, in Georgetown law jounal, v. 101, 2013, p. 1656, nota de rodapé $\mathrm{n}^{\mathrm{o}}$ 45. Nos Estados Unidos da América, a utilização recente - e crescente - é apontada por LAWRENCE S. CHANER; TOMAS G. APPLEMAN, Third-party litigation funding in the United States, in Revista de arbitragem e mediação, v. 32, 2012, pp. 185-187.

${ }^{653}$ JENNIFER A. TRUSZ. Full... op. cit., p. 1658.

${ }^{654}$ MAXI SCHERER, AREN GOLDSMITH; CAMILLE FLÉCHET. Third party funding in international arbitration in Europe: part 1 - funders' perspectives, in Revue de droit des affaires internationales, n. 2, 2012, pp. 209210. Disponível no endereço eletrônico http://ssrn.com/abstract=2348737; consulta em 21.02.2014. 
A situação se complica pela ausência de previsão expressa do dever de informar - que profissionais da área financeira defendem isentar suas empresas e as partes de informar a existência desse contrato ${ }^{655}-$ a entes que não sejam sujeitos do processo ou advogados. $\mathrm{O}$ temor concreto dessas empresas é que tal revelação impacte negativamente na deliberação do tribunal arbitral sobre os custos de sucumbência e na estratégia de condução do caso frente à parte contrária (que pode, por exemplo, paralisar o processo a fim de esgotar o capital do investidor na disputa com o objetivo de conseguir melhor posição de barganha em futuro acordo) ${ }^{656}$.

Ainda que algumas empresas de "funding" admitam revelar sua relação se assim se fizer necessário para a garantia da imparcialidade dos árbitros, sua colocação é de que essa revelação seja feita apenas ao tribunal arbitral. Isso, no entanto, impossibilitaria a parte adversa de realizar a checagem das relações do árbitro e, conforme o caso, recusá-lo ou impugná-1o ${ }^{657}$.

É importante que os profissionais da arbitragem estejam atentos ao desenvolvimento desse fenômeno, a fim de evitar, enquanto inexistirem regras claras a respeito da sua revelação ${ }^{658}$, situações de fragilidade do processo ou de anulação da sentença arbitral.

\subsubsection{Imparcialidade e afastamento do advogado}

Conforme amplamente demonstra o presente estudo, a proteção da imparcialidade do árbitro enseja, em regra, a utilização de mecanismos para o afastamento do julgador parcial

\footnotetext{
${ }^{655}$ É o que faz Christopher Bogart, CEO de uma das maiores financiadoras de litígios do mundo, Burford Capital, ao afirmar que "[t]his is not an arbitration funding issue per se, given that there is no legal, logical or equitable basis for requiring the disclosure of funding without also requiring the disclosure of other parties with economic interests in the outcome of a matter", que "[p]roviders of financing to a party or a case - whether litigation funders, banks or insurers - are not required to be disclosed" e que "[u]nder IBA guidelines, only parties and their affiliates can create such conflicts [of interest]". CHRISTOPHER BOGART. Third party funding in international arbitration - an overview of arbitration finance, p. 4; disponível no endereço eletrônico http://www.burfordcapital.com/wp-content/uploads/2013/02/Burford-article-Third-Partyv1.2internal-no-symbol.pdf; consulta em 21.02.2014.

${ }^{656}$ JENNIFER A. TRUSZ. Full ... op. cit., p. 1672.

${ }^{657}$ MAXI SCHERER. Third-party funding in arbitration, in Commercial dispute resolution, maio de 2012, p. 59.

${ }^{658}$ Proposta de regulamentação é apresentada por JENNIFER A. TRUSZ. Full... op. cit., pp. 1673-1680.
} 
(quando já findo o processo arbitral, a proteção da imparcialidade enseja a anulação da respectiva sentença). O afastamento do julgador tido como parcial é o caminho que melhor equilibra a exigência de celeridade e economicidade - pois o processo não é um fim em si, configurando um meio que deve atingir mais rapidamente e com os menores custos a sua finalidade - que é a solução do litígio conforme as regras de fundo escolhidas pelas partes.

A aparência de parcialidade do julgador pode ser ostentada $(i)$ desde antes do início do processo (como no caso em que o árbitro possui, anteriormente à sua nomeação, relação negocial significativa com uma das partes) ou ser desencadeada (ii) no curso desse procedimento, em razão (ii.1) de comportamento do próprio árbitro, (ii.l.a) aliado ao comportamento de uma das partes (como no caso de o árbitro estabelecer relação negocial paralela com uma das partes no curso do procedimento), ou (ii.l.b) não aliado ao comportamento das partes (como no caso de o árbitro adquirir em bolsa de valores ações da companhia que é parte no processo arbitral, sem o conhecimento desta); ou ainda em razão (ii.2) de eventos que não contaram com a participação do árbitro ou da parte (como no caso de uma companhia cliente do escritório do árbitro adquirir uma subsidiária ou coligada de uma das partes). Nesses casos todos, se o processo não tiver sido concluído, a proteção da imparcialidade se dá pelo afastamento do árbitro.

Há, no entanto, a hipótese em que o árbitro - que originalmente não se enquadrava em nenhuma das premissas de conteúdo características da aparência de parcialidade - assume essa aparência em razão de evento posterior à instauração do processo arbitral, motivado exclusivamente pelo comportamento (processual) de uma das partes, a qual, em momento mais avançado do procedimento, contrata para lhe representar profissional ou escritório que possui com o árbitro alguma das relações que satisfazem as premissas de conteúdo para configurar a aparência de parcialidade. Diferentemente das hipóteses tratadas no parágrafo acima, nesta última é a parte quem - com ato próprio - atenta contra a higidez do processo e dá causa à vulneração da imparcialidade do árbitro.

Ao cometer o ato imediatamente lesivo à imparcialidade ${ }^{659}$, a parte deve assumir a responsabilidade pelas suas consequências, que podem incluir o impedimento de atuação do seu novo patrono na causa. Essa conclusão pela responsabilidade processual da parte

${ }^{659} \mathrm{O}$ ato mediatamente lesivo é o que envolve ou envolveu o árbitro e o novo patrono contratado, redutível a uma das categorias que compõe as premissas de conteúdo tratadas no capítulo 3.4 do presente estudo. 
causa menos impacto à instrução do processo, evitando-se o desperdício de tempo e o aumento de custos envolvidos no refazimento dos atos processuais que seriam necessários caso o árbitro - e não o advogado com quem este possui relação - fosse nomeado.

Essa questão foi tratada nos casos ICSID Hrvatska v. Slovenia e Rompetrol v. Romania.

No caso Hrvatska v. Slovenia, dez dias antes da audiência de instrução, esta última apresentou manifestação com a lista de nomes das pessoas que iriam patrociná-la no ato, lista essa que continha o nome de advogado ("barrister") até então não identificado como pertencente à sua equipe, David Mildon. Referido advogado era membro do mesmo grupo de câmaras no qual o presidente do tribunal, entre outras, também participava ${ }^{660}$. O requerente solicitou revelação da relação entre o presidente e o novo advogado, o papel que este teria na audiência e quando ele tinha sido contratado. $\mathrm{O}$ árbitro presidente esclareceu que não tinha relação pessoal com o advogado, que a relação profissional se limitava àquela estabelecida na câmara, e que já havia participado de diversos procedimentos arbitrais com advogados da mesma câmara, sem que isso o impedisse de atuar imparcialmente. O Estado confirmou a inexistência de relação pessoal ou profissional entre o advogado e o árbitro, recusando-se a revelar quando o havia contratado e qual seria seu papel na audiência. Após novo pedido de informações sobre a contratação do advogado e nova recusa do Estado em prestá-las, o requerente alegou que a participação de advogado da mesma câmara que o árbitro, especialmente quando revelada às vésperas da audiência, ensejaria dúvidas justificadas em um observador razoável. No entanto, ao invés de requerer o afastamento do árbitro - o que levaria a atrasos no processo e elevação dos custos - o requerente solicitou ao tribunal ordem para impedir que o advogado participasse da audiência e dos atos processuais subsequentes. Após apontar a dificuldade da situação (se o advogado fosse afastado, o Estado alegaria violação ao seu direito de defesa; se não fosse, o investidor alegaria violação ao seu direito de ser julgado por um tribunal independente e imparcial), o tribunal arbitral considerou, em decisão de 6 de maio de $2008^{661}$ que (i) constituía seu dever zelar pelo processo e proferir sentença hígida, como guardião da

\footnotetext{
${ }^{660} \mathrm{O}$ presidente do painel era um "door tenant", ou seja, um "barrister" a quem era permitido trabalhar com um grupo de câmaras.

${ }^{661}$ Caso Hrvatska Elektroprivreda d.d. v. Republic of Slovenia (ICSID Case No. ARB/05/24), disponível no endereço eletrônico https://icsid.worldbank.org/ICSID/FrontServlet?requestType=CasesRH\&actionVal=showDoc\&docId=DC95 0_En\&caseId=C69; consulta em 21.02.2014.
} 
legitimidade processual; (ii) embora as câmaras nas quais os "barristers" atuam não se comportem como escritórios de advocacia e que a situação equivalente à então apresentada tivesse sido aceita em outros processos, essa aceitação não é universal e a situação era, sim, problemática. Por essas razões - e ainda que a Convenção ICSID ou o regulamento não conferissem explicitamente poder para o tribunal excluir um advogado, o direito de as partes escolherem o seu representante não se sobreporia ao princípio da imutabilidade próprio dos tribunais já constituídos (art. 56(1) da Convenção ICSID), razão pela qual o Estado seria livre para selecionar seus patronos antes da constituição do tribunal, mas não poderia alterar essa composição de modo a ameaçar a legitimidade do tribunal arbitral. Assim, concluindo que o afastamento do árbitro não seria viável diante da regra de imutabilidade do tribunal, este considerou que a participação do advogado seria imprópria, barrando-a.

No caso Rompetrol v. Romania, o Estado requereu ao tribunal arbitral (em 31 de julho de 2009) ordem para que o investidor afastasse do caso o advogado líder da sua equipe, Bartom Legum (que informou ter assumido o caso em 21 de julho de 2009, em substituição ao patrono anterior, François-Poncet que, após o início do procedimento, retirou-se da prática privada), sob a alegação de que ele, antes de se integrar ao escritório que representava o investidor (Salans \& Associés), havia sido empregado, por quatro anos, do escritório de advocacia do árbitro, do qual saiu sete meses antes de se envolver com o caso. Requereu, também, maiores informações ao investidor a respeito da relação entre o advogado e o árbitro indicado pelo investidor, Donald Francis Donovan, que foram prestadas, inclusive com a informação de que o advogado era assalariado sem participação nos lucros do escritório. Embora o tribunal tenha considerado a existência de poder inerente de salvaguardar o processo arbitral, consoante a decisão proferida no caso Hrvatska, afastou-se dela ao considerar inexistir necessária tensão entre o príncípio da imparcialidade do tribunal e o da livre escolha do representante pela parte. Nos casos em que essa tensão venha a existir, é dever do tribunal ponderar os princípios e atendê-los na medida do possível, devendo evitar o afastamento de advogado, que seria providência reservada a casos excepcionais. Relativamente aos eventos do caso, o tribunal apontou não ter encontrado neles "a real possibility that the Tribunal was biased" ou que tais eventos ensejassem "a reasonable basis, in terms of Article 14 of the ICSID Convention and Article 6 of the Rules for questioning the ability of the Tribunal or any of its Member to judge 
fairly or exercise independent judgment" ${ }^{, 62}$. O tribunal não entendeu que a associação pretérita do advogado ensejasse qualquer interesse financeiro ou material do advogado para com o árbitro e vice-versa, e que, diferentemente do que ocorreu no caso Hrvatska no qual, entendeu o tribunal, o afastamento do advogado poderia ser visto como uma sanção à conduta da parte em ter deixado para revelar a participação do advogado até o último momento - o tema foi tratado logo após a apresentação do novo advogado e sem a premência de uma decisão a ser proferida na undécima hora antes da audiência. Assim, o tribunal não afastou o advogado.

Ainda não é incontroverso o fundamento jurídico que possibilita ao tribunal, nos casos extremos, o afastamento do advogado ao invés do afastamento do árbitro: as justificativas variam entre a proteção da boa-fé e da vedação do abuso de direito pelas partes, a existência de um poder inerente do tribunal em tomar as medidas necessárias para garantir o direito de as partes apresentarem seu caso perante um tribunal imparcial, ou ainda a existência de um poder implícito do tribunal arbitral, derivado dos regramentos aplicáveis, nesse mesmo sentido ${ }^{663}$. No entanto, esse afastamento é método viável e sua utilização como proteção da imparcialidade justifica sua referência no presente estudo.

Independentemente do fundamento jurídico para sua vedação ou da busca pela eficiência (em tempo e custos) do processo arbitral, a recorrência e importância da contratação de advogado posteriormente à constituição do tribunal que possua relação com membro deste, a ponto de ensejar a aparência de parcialidade, foi tratada nas IBA Guidelines on Party Representation in International Arbitration de 2013, nos itens 5 e $6^{664}$. Não obstante a

${ }^{662}$ Caso The Rompetrol Group N.V. v. Romania (ICSID Case No. ARB/06/3). Decision of the Tribunal on the Participation of a Counsel, disponível no endereço eletrônico https://icsid.worldbank.org/ICSID/FrontServlet?requestType=CasesRH\&actionVal=showDoc\&docId=DC13 70_En\&caseId=C72; consulta em 21.02.2014.

663 JEFF WAINCYMER. Reconciling conflicting rights in international arbitration: the right to choice of counsel and the right to an independent and impartial tribunal, in Arbitration International, v. 26, n. 4, 2010, pp. 615-617. No texto, as decisões dos casos Hrvatska e Rompetrol são minudentemente analisadas.

${ }^{664}$ Respectivamente: "Once the Arbitral Tribunal has been constituted, a person should not accept representation of a Party in the arbitration when a relationship exists between the person and an Arbitrator that would create a conflict of interest, unless none of the Parties objects after proper disclosure" e "[t]he Arbitral Tribunal may, in case of breach of Guideline 5, take measures appropriate to safeguard the integrity of the proceedings, including the exclusion of the new Party Representative from participating in all or part of the arbitral proceedings." A integralidade do texto pode ser consultada no endereço eletrônico http://www.ibanet.org/Publications/publications_IBA_guides_and_free_materials.aspx\#partyrep; consulta em 21.02.2014. 
referência, o regramento não é de aplicação compulsória ${ }^{665}$, o que ainda gera incertezas sobre o seu alcance ${ }^{666}$.

${ }^{665}$ Consoante item 1: "The Guidelines shall apply where and to the extent that the Parties have so agreed, or the Arbitral Tribunal, after consultation with the Parties, wishes to rely upon them after having determined that it has the authority to rule on matters of Party representation to ensure the integrity and fairness of the arbitral proceedings."

${ }^{666}$ Sobre o assunto escreveu CARLOS AlBERTO CARMONA. As listas de árbitros, artigo ainda não publicado em poder do autor. 


\section{CONCLUSÕES}

Do desenvolvimento dos capítulos precedentes podem ser extraídas algumas conclusões, resumidas abaixo em forma de itens.

1. Experiências jurídicas nacionais utilizaram-se de modelos distintos para a padronização da imparcialidade do árbitro, segundo três técnicas principais: (i) tipificação legal dos casos de recusa ou impugnação; (ii) equiparação às causas de impedimento ou suspeição de juízes; e (iii) estabelecimento de um estado de coisas ou uma cláusula geral. Todas as técnicas apresentam alguma desvantagem, compreendendo, para a técnica (i) acima, a dificuldade ou impossibilidade de enquadramento de grande variedade de hipóteses passíveis de ocorrer nos casos concretos; para a técnica (ii) acima, a dificuldade de se adequar o regramento concebido para funcionário estatal (escolhido para julgar uma causa segundo as regras de distribuição de competência) ao árbitro (escolhido direta ou indiretamente pelas próprias partes); e para a técnica (iii) acima, a dificuldade de preenchimento do suporte fático da norma a ser aplicada, prejudicando a previsibilidade da conduta desejada e a harmonia das decisões. Instituições arbitrais (tais como a AAA, a IBA ou as câmaras e centros que administram processos arbitrais) também buscaram orientar a conduta dos profissionais envolvidos com a prática da arbitragem, no sentido de privilegiar a imparcialidade do árbitro, com a edição de regulamentos, códigos de ética ou guias de melhores práticas que, entretanto, esbarram nas mesmas dificuldades encontradas pelos modelos nacionais.

2. As tentativas de padronização dificilmente produzirão resultados satisfatórios sem o reconhecimento de um conteúdo à imparcialidade, hábil a superar as noções genéricas que giram em torno da ausência de "outras influências" (além dos argumentos das partes) no convencimento do julgador ou da sua "equidistância", ou que compreendam a imparcialidade como um fenômeno circunscrito à esfera da autonomia privada das partes, e que, por isso, possa ser objeto de renúncia. Piora o quadro a confusão entre essas noções genéricas a respeito da imparcialidade com as noções também genéricas a respeito da independência e neutralidade do árbitro, especialmente quando se afirma existir, entre tais noções, relação de causa e efeito ou interdependência. Tudo isso dificulta a interpretação das regras aplicáveis, prejudicando não apenas a sua convergência em nível sistemático, 
mas especialmente em prejuízo da previsibilidade e controle das condutas dos árbitros, das partes e de seus advogados nos casos concretos.

3. Para a identificação de um conteúdo à imparcialidade é necessária, antes, a tomada de consciência de que o ato de conhecer algo (e, portanto, interpretar e decidir) é precedido da pré-compreensão do intérprete. Essa pré-compreensão, por sua vez, é originada a partir das experiências até então vividas pelo intérprete; tudo o que ele vivenciou influencia no ato de conhecer (e decidir), de modo que as "outras influências" às quais o julgador não deveria estar exposto não caracterizam sua parcialidade. Ao contrário, elas configuram condição necessária para o julgamento. Não é por outra razão que as partes analisam os currículos, os contatos, as opiniões e os trabalhos dos árbitros que irão escolher, buscando potencializar suas chances de vitória no litígio.

4. Sendo certa a exposição do árbitro a influências outras além dos argumentos das partes, é preciso descartar esse fenômeno como característico da parcialidade e identificar, com apoio no modelo democrático de processo, outro fenômeno hábil a preencher o conteúdo da imparcialidade.

5. O modelo democrático de processo demanda que os argumentos das partes exerçam influência no desenvolvimento e na conclusão da relação jurídica processual. Assim, a parcialidade pode ser identificada como o impedimento, a vedação, a imunidade do julgador a essa influência. Assim, se o árbitro já está convencido a respeito de qual parte tem razão em determinado conflito sem permitir qualquer influência dos argumentos das partes (o que é totalmente diferente de o árbitro ter decidido casos análogos ou ter opinião em tese sobre a matéria discutida), resta caracterizada a parcialidade.

6. Configurando-se a imunidade à influência (de ao menos uma) das partes um fenômeno psíquico e, portanto, subjetivo, é necessário operacionalizar o conteúdo da imparcialidade, a fim de que ele possa ser aferido a partir de eventos objetivos ou intersubjetivos. É necessário, portanto, o recurso à aparência inferida a partir de eventos do mundo fático.

7. Não é qualquer evento ou qualquer aparência dele inferida o bastante para caracterizar a parcialidade ou a imparcialidade do árbitro. Essa aparência deve ser mensurada à luz de 
premissas de estrutura e premissas de conteúdo, por um intérprete consciente da existência e do funcionamento de um ambiente institucional no qual a arbitragem se desenvolve.

8. As premissas de estrutura estabelecem orientação para que a norma concreta respeite a coesão e a coerência do sistema normativo do qual é extraída pelo intérprete.

9. A primeira premissa de estrutura impõe o modelo democrático de processo como condição necessária para a elaboração de normas quando o evento fático está descrito na hipótese de regras vinculantes aplicáveis a determinado processo arbitral (isto é, quando há regra que imponha determinado comportamento ao árbitro com vistas à sua imparcialidade). A primeira premissa também impõe o modelo democrático de processo como condição necessária para a elaboração de normas quando não há, nas regras aplicáveis ao processo arbitral específico, alguma que preveja a hipótese subsumível ao evento ocorrido, isto é, quando não há regra que imponha um estado de coisas, mas não o modo de alcançá-lo. Assim, o modelo democrático de processo deve constituir a orientação para a elaboração de norma tanto para o caso em que somente a lei já imponha o comportamento tido como violador da imparcialidade (como, por exemplo, serem cônjuges árbitro e parte, consoante art. 14 da LA cumulado com o art. 134, inc. I, do CPC), como também para o caso em que outras regras - além das legais - assim o façam (como, por exemplo, a atuação pretérita do árbitro como mediador, consoante art. $13, \S 6^{\circ}$, da LA cumulado com o art. 5.2(k) do regulamento do CAM-CCBC). O modelo democrático de processo também deve orientar a elaboração de norma quando inexistam regras aplicáveis que imponham comportamento (como, por exemplo, a indicação do mesmo árbitro por um número excessivo de vezes, para decidir casos distintos, por partes representadas por um mesmo escritório de advocacia (aí se aplica somente o art. $13, \S 6^{\circ}$, da LA).

10. A segunda premissa de estrutura orienta o intérprete a elaborar norma - especialmente quando não há regra que imponha conduta específica - que satisfaça postulados hermenêuticos, tais como o da proporcionalidade ou da coerência e coesão sistemáticas. É o respeito a esses postulados que permitirão distinguir - com o apoio nas premissas de conteúdo - a situação em que o árbitro participou de um evento acadêmico com o advogado de uma das partes (o que não aparenta parcialidade), com a situação em que o árbitro tenha negócios habituais com esse advogado (o que aparenta parcialidade), bem como as respectivas consequências. 
11. As premissas de conteúdo auxiliam o intérprete na elaboração de norma que respeite a coerência interna entre a hipótese de fato normativa (que o intérprete irá formular) e o evento que se quer regular (que o intérprete irá descrever), mediante a categorização desses eventos e, dentro de cada categoria, a eleição de critérios para que esses eventos sejam analisados. Por exemplo, nos eventos redutíveis à categoria de "relação societária do árbitro com a parte" (numerada no presente estudo como 1.1.1), os critérios principais de análise envolvem a proximidade, a intensidade e a contemporaneidade dessa relação, bem como a existência de benefício econômico demonstrável, a imediatidade de sua auferição pelo arbitro com o julgamento do processo arbitral e sua substancialidade. Assim, muito mais aparente a parcialidade do árbitro que seja sócio direto da parte (e não titular de um fundo de investimento que detenha ações), que seja seu diretor (e não mero sócio sem cargo), que ostente essa posição ao tempo do processo (e não em passado distante), que seja titular de um número expressivo de ações (e não de quantia pequena), especialmente quando o julgamento irá atribuir capital diretamente à parte (e não apenas dificultar a situação de sua concorrente no mercado), em valores expressivos (que possam assim ser definidos tanto em termos absolutos quanto relativos, frente ao patrimônio do árbitro).

12. As premissas de estrutura não são analisadas anteriormente às premissas de conteúdo, pois é impossível elaborar uma norma - bem como verificar sua coerência sistemática sem o conhecimento da hipótese de fato que tal norma visa regular.

13. Ao analisar as premissas de estrutura e de conteúdo, o intérprete deve levar em conta o ambiente institucional no qual a arbitragem se desenvolve, estando consciente que, a despeito da existência de uma elite de árbitros, seu número tem aumentado e ensejado uma competição entre os profissionais com perfil para o exercício dessa função, profissionais esses que se comportam com vistas a aumentar seu capital simbólico em um mercado caracterizado por assimetrias, sobretudo de informação. Esse capital simbólico é agregado em três frentes (detenção de saber específico; manutenção de relações negociais e sociais dentro do mercado; e reconhecimento dos pares), razão pela qual o comportamento esperado dos possíveis árbitros que se voltem a essa acumulação de capital simbólico deve ser levado em conta pelo intérprete no momento de criação de norma a ser aplicada no caso prático. O intérprete também deverá levar em conta o perfil esperado do observador do evento fático que será descrito, pois diferentes observadores terão potencial para valorar - 
de modo diferenciado - o evento, com reflexos na análise das premissas de estrutura e de conteúdo.

14. Em vista da função que possui para a relação processual, a parcialidade do árbitro não pode ser reconhecida apenas nos casos de impedimento e suspeição de juízes. E mesmo as previsões quanto a esses últimos casos (arts. 134 e 135 do CPC) devem ser adaptadas para a aplicação na arbitragem, tendo em vista os diferentes estatutos aos quais estão sujeitos.

15. A noção mais fluida de independência do árbitro não se equipara ao conceito de independência do juiz e do Poder Judiciário, nem é preponderantemente objetiva, demandando do intérprete um juízo de valor sobre a relação do árbitro com a parte ou terceiro. Como a independência - diferentemente da imparcialidade - não tem função estrutural na relação processual desenvolvida na arbitragem, ela apenas pode ser tomada como um indicativo da aparência de parcialidade e um guia para que o árbitro exerça seu dever de revelação. Essas conclusões permitem uma leitura mais adequada dos arts. 13, § 6 , e $14, \S 1^{\circ}$, da LA.

16. De modo análogo, a noção também fluida de neutralidade do árbitro (tomada como pertencimento do julgador a um grupo de indivíduos do qual também pertençam as partes) somente tem relevância quando, no caso concreto, for indicativa da parcialidade do árbitro.

17. O dever de revelação possui natureza contratual e sua violação não dá causa, per se, à invalidação da relação processual (e de eventual sentença) arbitral, podendo ser tomada, no entanto, como indicativa da parcialidade do árbitro. A criação da norma concreta relativa ao dever de revelação deve tomar como ponto de partida um observador interessado, impondo ao árbitro o dever de proceder a pesquisas com vistas a detectar potenciais conflitos de interesses.

18. O binômio ciência-aceitação das partes com relação aos eventos que caracterizariam a parcialidade do árbitro não coloca a imparcialidade no círculo dos direitos dispositivos. As partes ainda devem respeitar o modelo democrático de processo, que impõe um julgador imparcial. Ao aceitarem árbitro envolvido em determinado evento, as partes declaram que ele não dá ensejo à criação de norma concreta que sancione a parcialidade do árbitro, e não que aceitam árbitro parcial. A ciência das partes sobre o evento deve ser demonstrável e 
sua aceitação deve ser expressa, salvo se as circunstâncias particulares (como, por exemplo, a existência de informação pública e acessível às partes sobre o árbitro e o silêncio das partes no momento em que tais fatos poderiam ser alegados) orientarem em sentido diverso.

19. Os critérios de análise da imparcialidade devem ser os mesmos para todos os membros do tribunal arbitral, sendo que a parcialidade de um árbitro é suficiente para a invalidação de uma sentença.

20. Não bastassem os problemas e dificuldades ensejados pelo estado atual da prática arbitral, o desenvolvimento desta colocará, em breve, novos desafios aos profissionais atuantes na área, que demandarão maior quantidade de e mais aprofundadas investigações sobre o tema. 


\section{PRINCIPAIS ABREVIATURAS}

Amcham - American Chamber of Commerce

CA-AMCHAM - Centro de Arbitragem da Câmara Americana de Comércio

CAMARB - Câmara de Arbitragem Empresarial-Brasil

CAM-CCBC - Centro de Arbitragem e Mediação da Câmara de Comércio Brasil-Canadá

CCI - Corte Internacional de Arbitragem da Câmara de Comércio Internacional

CCMA-CIESP/FIESP - Câmara de Conciliação, Mediação e Arbitragem Ciesp/Fiesp

CIETAC - China International Economic and Trade Arbitration Commission

CPC - Código de Processo Civil brasileiro

CPP - Código de Processo Penal brasileiro

FAA - Federal Arbitration Act

GAC - General Arbitration Council of the Textile and Apparel Industries

IBA - International Bar Association

ICJ - International Court of Justice

ICSID - International Centre for Settlement of Investment Disputes

LA - Lei de Arbitragem brasileira

LCIA - The London Court of International Arbitration

NAFTA - North American Free Trade Agreement

NASD - National Association of Securities Dealers

RUAA - Revised Uniform Arbitration Act

SCC - The Stockholm Chamber of Commerce

STJ - Superior Tribunal de Justiça

TJSP - Tribunal de Justiça do Estado de São Paulo

UNCITRAL - United Nations Commission on International Trade Law 


\section{BIBLIOGRAFIA}

Abbagnano, Nicola. Dicionário de filosofia (trad. Alfredo Borsi). São Paulo: Martins Fontes, 2007.

ABBud, ANDRÉ De AlBUQUERQUe CAVAlCANTI. A soft law na arbitragem internacional: $a$ obtenção de provas. Tese apresentada como requisito para a obtenção do título de Doutor em Direito Processual na Faculdade de Direito da USP, São Paulo, 2013.

Relatório "Arbitragem no Brasil - Pesquisa CBAr-IPsos", 2012, p.

22, disponível no endereço eletrônico http://www.cbar.org.br/PDF/Pesquisa_CBAr-Ipsosfinal.pdf; consulta em 21.02.2014.

Afonso da Silva, VIRGílio. O proporcional e o razoável, in Revista dos Tribunais on line, v. 798, 2002, pp. 23-50.

Afonso, Orlando Viegas Martins. Poder judicial - Independência in dependência. Coimbra: Almedina, 2004.

Aksen, Gerald, The tribunal's appointment, in Newman, Lawrence W.; HiLl, Richard D. (Ed.). The leading arbitrators' guide to international arbitration. 2. ed. New York: Juris Publishing, 2008, pp. 31-40.

Alcalá, Juan M.; Cardozo, Camilo; Salomon, Claudia T. Chapter 3 - arbitrator disclosure standards in a state of flux, in HANESSIAN, GRANT (Ed.). ICDR awards and commentaries. New York: JurisNet, 2012, pp. 63-83.

ALLISON, JOHN R. A process value analysis of decision-maker bias: the case of economic conflict of interest, in American business law journal, v. 32, n. 4,1995, pp. 481-540.

Almeida, André Alves De. Processualidade jurídica e legitimidade normativa. Belo Horizonte: Fórum, 2005.

Alves, RAFAEL FRANCISCO. A imparcialidade do árbitro no direito brasileiro: autonomia privada ou devido processo legal?, in Revista de arbitragem e mediação, n. 7, 2005, pp. 109-126.

Armani, GiUSEPPE (Ed.). Enciclopedia del diritto. 2. ed. Italia: Garzanti, 2001. 
Aroca, JuAn Montero. Independencia y responsabilidad del juez. Madrid: Civitas, 1990. Ávila, HumBerto. Teoria dos princípios. 14. ed. São Paulo: Atlas, 2013.

BAM, DMITRY. Making appearances matter: recusal and the appearance of bias, in Brigham Young University law review, 2011, pp. 943-1003.

Baptista, Luiz Olavo. Arbitragem comercial e internacional, São Paulo: Lex Magister, 2011.

Dever de revelação do árbitro: extensão e conteúdo. Inexistência de infração. Impossibilidade de anulação da sentença arbitral, in Revista de Arbitragem e Mediação, v. 36, 2013, pp. 199-217.

Inutilidades e futilidade daninha: a questão das impugnações de árbitro descabidas, in Revista direito ao ponto, ano 6, n. 8, 2013, pp. 27-29.

BARBerio, Sergio José. La imparcialidad judicial, in Activismo y garantismo procesal. Córdoba: Academia Nacional de Derecho y Ciencias Sociales de Córdoba, 2009, pp. 21 31.

Barbosa Moreira, José Carlos. Reflexões sobre a imparcialidade do juiz, in Temas de direito processual - sétima série. São Paulo: Saraiva, 2001, pp. 19-30.

Barrocas, Manuel Pereira. Manual de arbitragem. Coimbra: Almedina, 2010.

BARros, SuZANA DE TOledo. O princípio da proporcionalidade e o controle de constitucionalidade das leis restritivas de direitos fundamentais. 2. ed. Brasília: Brasília Jurídica, 2000.

Bedaque, José Roberto dos SAntos. Efetividade do processo e técnica processual. São Paulo: Malheiros, 2006.

BERNINI, GIORGIO. Report on neutrality, impartiality, and independence, in The arbitral process and the independence of arbitrators. Paris: ICC Publishing, 1991, pp. 31-37.

Billier, JeAn-Cassien; Maryioli, AglaÉ. História da filosofia do direito (trad. Maurício de Andrade). Barueri: Manole, 2005. 
BISHOP, DOAK; REED, LuCY. Practical guidelines for interviewing, selecting. and challenging party-appointed arbitrators in international commercial arbitration, in Arbitration international, v. 14, n. 4, 1998, pp. 395-429.

BITTAR, EDUARDO C. B. Hans-Georg Gadamer: a experiência hermenêutica e a experiência jurídica, in Hermenêutica plural. São Paulo: Martins Fontes, 2002.

Bleicher, Josef. Hermenêutica contemporânea (trad. Maria Georgina Segurado). Rio de Janeiro: Edições 70, 1980.

BOGART, CHRISTOPHER. Third party funding in international arbitration - an overview of arbitration finance, pp 1-4; disponível no endereço eletrônico http://www.burfordcapital.com/wp-content/uploads/2013/02/Burford-article-Third-Partyv1.2internal-no-symbol.pdf; consulta em 21.02.2014.

BOISSÉSON, MATTHIEU DE. Le droit français de l'arbitrage interne et international. Paris: Joly, 1990.

BOND, STEPHEN. The experience of the ICC in the confirmation/appointment stage of an arbitration, in Northwestern journal of international law \& business, v. 12, n. 1, 1991, pp. $1-23$.

Bonício, Marcelo José Magalhães. Proporcionalidade e processo. São Paulo: Atlas, 2006.

BORN, GARY. International commercial arbitration, v. II. London: Wolters Kluwer, 2009.

The different meanings of an arbitrator's "evident partiality" under U.S. law, postado no Kluwer arbitration blog em 20.03.2013. Disponível no endereço eletrônico http://kluwerarbitrationblog.com/blog/2013/03/20/the-different-meanings-of-anarbitrators-evident-partiality-under-u-s-law/; consulta em 21.02.2014.

Brekoulakis, Stavros. Systemic bias and the institution of international arbitration: a new approach to arbitral decision-making, in Journal of international dispute settlement, v. 4, n. 3, 2013, pp. 553-585.

Brower, CHARLeS N. The Ethics of arbitration: perspectives from a practicing international arbitrator, in Berkeley journal of international law publicist, v. 5, 2010, pp. $1-31$. 
Buarque de Holanda, Sérgio. O homem cordial, in Raízes do Brasil, 26. ed. São Paulo: Companhia das Letras, 1995, pp. 141-151.

BuRDZY, KRZYSZTOF. The search for certainty. Singapore: Word Scientific Publishing, 2009.

BYRne, Olga K. A new code of ethics for commercial arbitrators: the neutrality of partyappointed arbitrators on a tripartite panel, in Fordham urban law journal, v. 30, 2003, pp. 1815-1847.

CABral, Antonio do Passo. Il principio del contraddittorio come diritto d'influenza e dovere di dibattito, in Rivista di diritto processuale, v. 2, 2005, pp. 449-464.

. Nulidades do processo moderno. 2. ed. Rio de Janeiro: Forense, 2010.

CAlAmANDrei, PIERo. Giustizia e politica: sentenza e sentimento, in Processo $e$ democrazia. Padova: CEDAM, 1954, pp. 43-66.

CAPPelletti, Mauro. Ideologias en el derecho procesal, in Proceso, ideologias, sociedad (trad. Santiago Sentís Melendo). Buenos Aires: Ediciones Juridicas Europa-America, 1974.

CARbonneau, Thomas E. The ballad of transnational arbitration, in University of Miami law review, v. 56, n. 4, 2002, pp. 733-829.

Carmona, Carlos Alberto. A arbitragem no Código de Processo Civil Brasileiro. Tese apresentada como requisito para a obtenção do título de Doutor em Direito Processual na Faculdade de Direito da USP, São Paulo, 1990.

. Arbitragem e processo. 3. ed. São Paulo: Atlas, 2009.

. As listas de árbitros, artigo ainda não publicado em poder do autor.

Em torno do árbitro, in Revista de arbitragem e mediação, v. 28,

2011, pp. 47-63.

Caron, David D.; Caplan, lee M.; Pellonpaa, Matti. The UnCitral arbitration rules: a commentary, New York: Oxford University Press, 2006

CARreira Alvim, José EduARdo. Tratado geral da arbitragem. Belo Horizonte: Mandamentos: 2000. 
CARTER, JAMES H. Improving life with the party-appointed arbitrator: clearer conduct guidelines for 'nonneutrals', in American review of international arbitration, v. 11, 2000, pp. 295-305.

Reaching consensus on arbitrator conflicts: the way forward, in Dispute resolution international, v. 6, 2012, pp. 17-35.

CAVANI, Renzo. Contra as "nulidades-surpresa": o direito fundamental ao contraditório diante da nulidade processual, in Revista de processo, v. 218, 2013, pp. 65-78.

Chaner, Lawrence S.; Appleman, Tomas G., Third-party litigation funding in the United States, in Revista de arbitragem e mediação, v. 32, 2012, pp. 175-190.

Cintra, Antonio Carlos de Araújo; Grinover, Ada Pellegrini; Dinamarco, CÂndido Rangel. Teoria Geral do Processo, 1. ed. São Paulo: RT, 1974. ; Teoria Geral do Processo,

29. ed. São Paulo: Malheiros, 2013.

Clay, Thomas. Arbitrage et modes alternatifs de règlement des litiges, in Recueil Dalloz, n. 44/7537, 27.12.2012, pp. 2991-3004.

Clay, Thomas. L'application perlée du règlement d'arbitrage pour la contestation des liens non révélés entre arbiter et conseil, in Revista de arbitragem e mediação, v. 33, pp. 167-188.

. Note sous CA Paris, 18 décembre 2008, in Revue de l'arbitrage, 2009, n. 1, pp. 190-205.

Quem são os árbitros internacionais. Abordagem sociológica, in Revista de arbitragem e mediação, v. 6, 2005, pp. 107-125.

COLE, SARAH RUdOLPH. Incentives and arbitration: the case against enforcement of executory arbitration agreements between employers and employees, in University of Missoury - Kansas City law review, n. 64, pp. 449-483.

Committee on International Commercial Arbitration. Report and Preliminary Draft Convention adopted by the Committee on International Commercial Arbitration at 
its meeting of 13 March 1953, in ICC Publication, n. 174, 1953, p. 7 [=The ICC International Court of Arbitration Bulletin, v. 9, 1998].

CONTIPELli, ERnANI. Aplicação da norma jurídica. São Paulo: Quartier Latin, 2007.

Couto e Silva, Clóvis DO. A obrigação como processo. Rio de Janeiro: Editora FGV, 2007.

Craig, W. Lawrence. Some trends and developments in the laws and practice of international commercial arbitration, in Texas international law journal, v. 30, n. 1, 1995, pp. $1-58$.

; Park, William W.; Paulsson, Jan. International Chamber of Commerce arbitration, 3. ed. Oceana Publications, 2000.

DAELE, KAREL. Challenge and disqualification of arbitrators in international arbitration. Netherlands: Kluwer Law International, 2012.

DAMASKA, MIRJAN R. A continental lawyer in an american law school: trials and tribunals of adjustment, in University of Pennsylvania law review, 1968, pp. 1363-1378.

DANIELSSON, KAR-EIK; TUDE, BJÖRN. Sweden: two different arbitration cases, disponível no endereço eletrônico http://www.iflr.com/Article/2176818/Sweden-Two-differentarbitration-cases.html; acesso em 21.02.2014.

Dazalay, Yves; Garth, Bryant G. Dealing in virtue: international commercial arbitration and the construction of a transnational legal order. Chicago: The University of Chicago Press, 1996.

DE SANTO, VíctoR. Diccionario de derecho procesal. 2. ed. Buenos Aires: Editorial Universidad, 1995.

Derains, Yves; Schwartz, ERIC. A Guide to the ICC Rules of Arbitration, 2. ed. The Hague: Kluwer Law International, 2005.

Dinamarco, CÂNDido RANGel. A arbitragem na teoria geral do processo. São Paulo: Malheiros, 2013. . A instrumentalidade do processo, 3. ed. São Paulo: Malheiros, 1993. 
DONAHEY, M. SCOTT. The independence and neutrality of arbitrators, in Journal of international arbitration, v. 9, n. 4, 1992, pp. 31-42.

DONAVAN, FRANCIS DONALD. International commercial arbitration and public policy, in New York University journal of international law and politics, v. 27, 1995, pp. 645-657.

DRAHOZAL, CHRISTOPHER R. Arbitrator selection and regulatory competition in international arbitration law, in DRAHOZAL, CHRISTOPHER R.; NAIMARK, RICHARD W. (Ed.). Towards a science of international arbitration. The Hague: Kluwer Law International, 2004, pp. 167-186.

ENGISCH, KARL. Introdução ao pensamento jurídico (trad. J. Baptista Machado). 7. ed. Lisboa: Fundação Calouste Gulbenkian, 1996.

ENRIQUE M. FALCón. Comunicación y proceso, in Revista de processo, n. 157, pp. 103128.

Feltham, Brian. Partiality and impartiality in ethics, in Feltham, Brian; CotTInGHAm, JOHN. Partiality and impartiality: morality, special relationships and the wider world, New York: Oxford, 2010, pp. 1-25.

FERrAZ JÚNIOR, TÉRCIO SAMPAIO. Introdução ao estudo do direito. 2. ed. São Paulo: RT, 1996.

. Suspeição e impedimento na arbitragem: sobre o dever de revelar na

Lei 9.307/1996, in Revista de arbitragem e mediação, v. 28, 2011, pp. 65-82.

Ferro, MARCElo Roberto. Apontamentos sobre a independência dos árbitros, in ADAMEK, MARCElo VIEIRA VON (Ed.). Temas de direito societário e empresarial contemporâneos. São Paulo: Malheiros, 2011, pp. 849-886.

FLAMM, RICHARD E. History of and problems with the federal judicial disqualification framework, in Drake law review, v. 58, 2010, pp. 751-763.

FouchaRd, PHILliPE. Le statut de l'arbitre dans la jurisprudence française, in Revue de l' arbitrage, 1996, n. 3, pp. 325-372. 
Les rapports entre l'arbitre et les parties et l'institution arbitrale, in Bulletin de la Cour Internationale d'arbitrage de la CCI: 1995 Supplement Special - Le statut de l'arbitres. Paris: ICC Publishing, pp. 12-21.

FRANCK, SUSAN D. The role of international arbitrators, in International law students association journal of international \& comparative law, v. 12, 2006, pp. 499-521.

FrANK, JoHn P. Disqualification of judges, in Yale law journal. v. 56, 1947, pp. 605-629.

Freire, Antonio Manuel Peña. La garantía en el estado constitucional de derecho. Madrid: Trotta, 1997.

Frost, AmANDA. Keeping up appearances: a process-oriented approach to judicial recusal, in University of Kansas law review, v. 35, 2005, pp. 531-593.

FRY, JASON; GREENBERG, SIMON. The arbitral tribunal: applications of articles 7-45 of the ICC Rules in recent cases; in ICC International Court of Arbitration bulletin, v. 20, n. 2 , 2009, pp. 12-32.

GABRIEL, HenRy; RAYMOND, ANJANETTE H. Ethics for commercial arbitrators: basic principles and emerging standards, in Wyoming law review, v. 5, 2005, pp. 453-470.

GadAmer, Hans-Georg. Verdade e método (trad. Flávio Paulo Meurer). 3. ed. Petrópolis: Vozes, 1999.

Gaillard, Emmanuel. Teoria geral da arbitragem (trad. Natália Mizrahi Lamas). São Paulo: Atlas, 2014.

; Savage, John (Ed.). Fouchard Gaillard Goldman on international arbitration, The Hague: Kluwer Law International, 1999.

Galdino, Flávio. Princípio da imparcialidade judicial, in Torres, Ricardo; Galdino, Flávio; Kataoka, Eduardo. Dicionário de princípios jurídicos. São Paulo: Elsevier, 2011, pp. 539-595.

GÉLINAS, FABIEN. The independence of international arbitrators and judges: tampered with or well tempered?, in New York international law review, v. 24, n. 1, 2011, pp. 1-48.

Geyh, Charles GARDNER. Judicial disqualification: an analysis of Federal Law. 2. ed. Federal Judicial Center, 2010. 
GINSBURG, TOM. The culture of arbitration, in Vanderbilt jornal of transnational law, $\mathrm{v}$. 36, 2003, pp. 1335-1345.

GIRALDO-CARRILlO, NATAlia. The 'repeat arbitrators' issue: a subjective concept, in Revista colombiana de derecho intenacional, v. 19, 2011, pp. 75-106.

Glossner, OtTOARndt, From New York (1958) to Geneva (1961) - a veteran's diary, in Enforcing arbitration awards under the New York Convention - experience and prospects, New York: United Nations, 1999, pp. 5-7.

Gomes, Luiz Flávio. A questão do controle externo do Poder Judiciário: natureza e limites da independência judicial no Estado Democrático de Direito. São Paulo: RT, 1993.

Guerreiro, AleXANDre TAVARES. Fundamentos da arbitragem comercial internacional. Tese apresentada como requisito para a obtenção do título de Doutor em Direito Processual na Faculdade de Direito da USP, São Paulo, 1989.

Gusy, Martin F.; Hosking, James M.; Schwarz, Franz T. A guide to the ICDR International Arbitration Rules, New York: Oxford University Press, 2011.

HABERMAS, JÜRgEn. Direito e democracia: entre facticidade e validade (trad. Flávio Beno Siebeneichler), v. II, 2. ed. Rio de Janeiro: Tempo Brasileiro, 2003.

HACKING, DAVID. Ethics, elitism, eligibility: a response: what happens if the icelandic arbitrator falls through the ice?,in Journal of international arbitration, v. 15, n. 4, 1998, pp. 73-79.

Heidegger, Martin. Ser e tempo (trad. Marcia Sá Cavalcante Schuback). Parte I, 15. ed. Petrópolis: Vozes, 2005.

Heintz, Tom PhilipPe; Cerqueira, Gustavo Vieira da Costa. A nova interpretação da obrigação de independência do árbitro na França: ad extirpanda?, in Revista de arbitragem e mediação, v. 32, 2012, pp. 389-418.

Racionalização do dever de revelação no direito

francês da arbitragem, in Revista de arbitragem e mediação, v. 362, 2012, pp. 411-431.

HeLMER, ElENA V., International commercial arbitration: americanized, "civilized", or harmonized?, in Ohio State journal on dispute resolution, v. 19, n. 1, 2003, pp. 35-67. 
Henrique Filho, Ruy Alves. Direitos fundamentais e processo. São Paulo: Renovar, 2008 .

HENRY, MARC. Le devoir d'indépendance de l'arbitre, Paris: LGDJ, 2001.

Le devoir de révélation dans les rapports entre arbitres et conseils: de la suggestion aux electrochocs, in Cahiers de l'arbitrage, 2011, n. 3, pp. 787-798.

. Le obligations d'indépendance et d'information de l'arbitre à la lumière de la jurisprudence récente, in Revue de l'arbitrage, 1999, n. 2, pp. 193-224.

HobBes, Thomas. The English works. v. III, London: John Bohn, 1840, disponível no endereço eletrônico http://files.libertyfund.org/files/585/Hobbes_0051-03_EBk_v7.0.pdf; consulta em 21.02.2014.

. The English works. v. IV, London: John Bohn, 1840, disponível no

endereço

eletrônico

https://archive.org/stream/englishworksofth029531mbp\#page/n147/mode/2up; consulta em 21.02.2014.

HoBÉR, KAJ. Arbitration reform in Sweden, in Arbitration international, v. 17, n. 4, 2001, pp. 351-387.

HoRSMANS, G. La loi belge du 19 mai 1998 sur l'arbitrage, in Revue d'arbitrage, 1999, n. 3, pp. 475-540.

HUNTER, MARTIN. Ethics of the International Arbitrator. Trecho transcrito por Greenberg, Simon; Kee, Christopher; Weeramantry, J. Romesh. International commercial arbitration: an Asia Pacific perspective. New York: Cambridge University Press, p. 263.

IBA CONFlicts subCOMmitteE. The IBA Guidelines of Conflicts of Interest in International Arbitration: The first five years 2004-2009, in Dispute resolution international, v. 4, n. 1, 2010, pp. 5-53.

JACOBS, TRAVIS. Arbitrator or private investigator: should the arbitrator's duty to disclose include a duty to investigate?, in Journal of dispute resolution?, 1997, n. 1, pp. 133-142.

Jornal Valor Econômico, caderno “Legislação \& Tributos”, 08.08.2003, p. E-1. 
Júdice, José Miguel; Duarte, Tiago. A anulação de sentenças ICSID: corrigir as sentenças ou corrigir as tendências?, in SELMA FERREIRA LEMES; InEz BALBINO (Ed.). Arbitragem: temas contemporâneos. São Paulo: Quartier Latin, 2012, pp. 327-357.

Jung, HelEnA. SCC practice: challenges to arbitrators - SCC Board decisions 20052007, pp. 13-15, disponível no endereço eletrônico http://www.sccinstitute.se/filearchive/2/28190/04-Art32-Jung.pdf; consulta em 21.02.2014. Kant, IMmanuel. Fundamentação da metafísica dos costumes (trad. Paulo Quintela). Lisboa: Edições 70, 2007.

KAPELIUK, DAPHNA. The repeat appointment factor: exploring decision patterns of elite investment arbitrators, in Cornell law review, v. 96, 2010, pp. 47-90.

KAPLAN, MiCHAEL I. Solving the pitfalls of impartiality when arbitrating in China: how the lessons of the Soviet Union and Iran can provide solutions to western parties arbitrating in China, in Penn State law review, v. 110, 2005-2006, pp. 769-807.

KAUfmann-Kohler, Gabrielle; StUCKI, Blaise. International arbitration in Switzerland: a handbook for practitioners. The Hague: Kluwer Law International, 2004.

KENNEDy, DeserIEE A. Predisposed with integrity: the elusive quest for justice in tripartite arbitrations, in Georgetown journal of legal ethics, v. 8, 1994, pp. 749-790.

KING, RONNIE; GIARETTA, BEN. Independence, impartiality and challenging the appointment of an arbitrator, in The international comparative legal guide to: international arbitration 2005, London: Global Legal Group, 2005, pp. 26-29.

KOCH, CHRISTOPHER. Standards and procedures for disqualifying arbitrators, in Journal of international arbitration, v. 20, n. 4, 2003, pp. 325-353.

KuO, HouchIH. The issue of repeat arbitrators: is it a problem and how should the arbitration institutions respond?, in Contemporary Asia arbitration journal, n. 4, 2011, pp. 247-272.

Kurkela, Matti S.; Turunen, Santtu. Due process in international commercial arbitration. 2. ed. New York: Oxford, 2010.

Kuyven, LuIZ Fernando MARTINS. O necessário precedente arbitral, in Revista de Arbitragem e Mediação, v. 36, 2013, pp. 295-315. 
LALIVE, PIERRE. On neutrality of the arbitrator and of the place for arbitration, in Reymond, Claude; Bucher, EugÈne (Ed.). Swiss essays on international arbitration. Zurich: Schulthess Polygraphischer Verlag, 1984, pp. 23-33.

Landau, TOBy, Composition and establishment of the tribunal: articles 14 to 36, in American review of international arbitration, v. 9, 1998, pp. 45-153.

HELENA. The regulation of international commercial arbitration: comparative trends and tensions, in Koichi Hamada; Mitsuo Matsushita; ChiKara Komura. Dreams and dilemmas: economic friction and dispute resolution in the Asia-Pacific, Singapore: Institute of Southeast Asian Studies, 2000, pp. 439-463

LANDOLT, PhILlIP. The IBA Guidelines on Conflicts of Interest in International Arbitration: an overview, in Journal of international arbitration, v. 22, 2005, pp. 409-418.

Larenz, KarL. Metodologia da ciência do direito (trad. José Lamego). 3. ed. Lisboa: Fundação Calouste Gulbenkian, 1997.

LAWSON, DAVID A. Impartiality and independence of international arbitrations. Commentary on the 2004 IBA Guidelines on Conflicts of Interest in International Arbitration, in ASA Bulletin, vol. 23, n. 1, 2005, pp. 22-44.

LeÃes, LuIz GastÃo PAes de BARRos. Ensaio sôbre arbitragens comerciais, São Paulo: RT, 1966.

LeAl, Rosemiro Pereira. Teoria processual da decisão jurídica. São Paulo: Landy, 2002.

LEe, ILHYUNG. Practice and predicament: the nationality of the international arbitration (whit survey results), in Fordham international law journal, v. 31, n. 3, 2008, pp. 603-633.

Lemes, SElma MARIA FERREIRA. Árbitro: princípios da independência e imparcialidade. São Paulo: LTr: 2001.

- O dever de revelação do árbitro, o conceito de dúvida justificada quanto a sua independência e imparcialidade )art. 14, § 1 ${ }^{\circ}$, da Lei 9.307/1996) e a ação de nulidade de sentença arbitral (art. 32, II, da Lei 9.307/1996), in Revista de Arbitragem e Mediação, v. 36, 2013, pp. 231-251. 
Lew, Julian D. M.; Mistelis, Loukas A.; Kröll, Stefan Michael. Comparative international commercial arbitration. The Hague: Kluwer Law International, 2003.

LI, JiAluE. China, a sui generis case for the western rule-of-law model, in Georgetown journal of international law, v. 41, 2010, pp. 711-748.

LiEBERMAN, SETH H. Something's rotten in the state of party-appointed arbitration: healing ADR's black eye that is "nonneutral neutrals", in Cardozo journal of conflict resolution, v. 5, 2004, pp. 215-245.

LiMA JÚNIOR, JAYME BENVENUTO (Ed.). Independência dos juízes no Brasil: aspectos relevantes, casos e recomendações. Recife: Gajop; Bagaço, 2005.

LinARES, JuAn Francisco. Razonabilidad de las leyes. 2. ed. Buenos Aires: Astreas, 1970. LINDSTRÖM, NIKLAS. Challenges to arbitrators - decisions by the SCC Board during 2008-2010, pp. 1-20; disponível no endereço eletrônico http://www.skiljedomsföreningen.se/\$2/file/challenges-to-arbitrators-decisions-by-the-sccboard-during-20081.pdf; consulta em 21.02.2014.

LOWENFELD, ANDREAS F., The party-appointed arbitrator: further reflections, in Newman, Lawrence W.; Hill, Richard D. (Ed.). The leading arbitrators' guide to international arbitration. 2. ed. New York: Juris Publishing, 2008, pp. 41-48.

LutTRell, SAmUel Ross. Australia adopts the 'real danger' test for arbitrator bias, in Arbitration international, v. 26, n. 4, 2010, pp. 625-632.

Bias challenge in international commercial arbitration: the need for $a$ 'real danger' test. The Hague: Kluwer Law International, 2009.

MacCormick, NeIL. Argumentação jurídica e teoria do direito (trad. Waldéa Barcelos). São Paulo: Martins Fontes, 2006.

Magalhães, José Carlos de; Baptista, Luiz Olavo. Arbiragem comercial. Rio de Janeiro: Freitas Bastos, 1986.

MaInLAND Richard R. Full Disclosures, in Los Angeles lawyer, nov. 2011, pp. 29-35; disponível no endereço eletrônico http://www.lacba.org/Files/LAL/Vol34No8/2865.pdf; consulta em 21.02.2014. 
MALINTOPPI, LORETTA. Independence, impartiality and duty of disclosure of arbitrators, in Peter Muchlinski; Federico OrTino; Christoph SCHREUER (Ed.). Oxford handbook of international investment law. New York: Oxford University Press, 2008, pp. 789-829.

MANZANARES BASTIDA, BRUNO. The independence and impartiality of arbitrators in International commercial arbitration, in Revista e-mercatoria, v. 6, 2007, pp. 1-15.

Martins, Pedro A. Batista. Apontamentos sobre a lei de arbitragem. Rio de Janeiro: Forense, 2008.

Dever de revelar do árbitro, in Revista de Arbitragem e Mediação, v.

36, 2013, pp. 219-229.

Martins-Costa, Judith. O direito privado como um "sistema em construção": as cláusulas gerais no Projeto do Código Civil Brasileiro, in Revista de Informação Legislativa, n. 139, 1998, pp. 5-22.

- Um aspecto da obrigação de indenizar: notas para uma sistematização dos deveres pré-negociais de proteção no direito civil brasileiro, in Revista dos Tribunais, v. 867, Separata, 2011, pp. 11-51.

Mclaughlin, Joseph T.; Scanlon, Kathleen M.; Pan, Catherine X. Planning for commercial dispute resolution in mainland China, in The american review of international arbitration, v. 16, 2005, pp. 133-156.

MCLEAn, DAVID J.; WiLSON, SEAn-PATRICK. Is three a crowd? Neutrality, partiality and partisanship in the context of tripartite arbitrations, in Pepperdine dispute resolution law journal, v. 9, n. 1, 2012, pp. 167-184.

Medina, José M. Chillón; Merchán, José F. Merino. Tratado de arbitraje privado interno e internacional. Madrid: Editorial Civitas, 1978.

Megale, Damasceno, Maria Helena e Silva. Hermenêutica jurídica: interpretação das leis e dos contratos. Belo Horizonte: Faculdade de Direito da UFMG, 2001.

Mello, José Luiz de AnHAiA. Da separação de podêres à guarda da constituição: as côrtes constitucionais. Dissertação para concurso à catedra de Direito Constitucional da Faculdade de Direito da Universidade de São Paulo. São Paulo, 1968. 
Melo, Marcos Bernardes De. Teoria do fato jurídico: plano da existência, 7. ed. São Paulo: Saraiva, 1995.

MENKEL-MEAdOw, CARRIE Are cross-cultural ethics standards possible or desirable in intenational arbitration?, in Mélanges en l'honneur de Pierre Tercier. Zurich: Schulthess Verlag, 2008, pp. 883-904.

. Ethics and professionalism in nonadversarial lawyering, in Forida State University law review, v. 27, pp. 161-188.

MERKIN, RoBerT. Arbitration Act 1996, an annotated guide. London: Informa Professional, 1996.

Miranda, Agostinho Pereira. O estatuto deontológico do árbitro: passado, presente e futuro, in III Congresso do Centro de Arbitragem da Câmara de Comércio e Indústria Coimbra: Almedina, 2010, pp. 59-71.

Montoro, MARCOS ANDrÉ FRAnCO. Flexibilidade do procedimento arbitral, Tese apresentada como requisito para a obtenção do título de Doutor em Direito Processual na Faculdade de Direito da USP, São Paulo, 2010

Moreno, Faustino Cordón. El arbitraje de derecho privado. Cizur Menor: Editorial Aranzadi, 2005.

Mourre, AleXIS. Are unilateral appointments defensible? On Jan Paulsson's moral hazard in international arbitration, in Kluwer arbitration blog, 05.10.2010; disponível no endereço eletrônico http://kluwerarbitrationblog.com/blog/2010/10/05/are-unilateralappointments-defensible-on-jan-paulsson\%E2\%80\%99s-moral-hazard-in-internationalarbitration/; consulta em 21.02.2014.

MULlerAt, RAMON. Arbitrator's conflicts of interest revisited: a contribution to the revision of the excellent IBA Guidelines of Conflicts of Interest in International Arbitration, in Spain arbitration review, v. 14, 2012, pp. 61-99.

Mustil, Michael. Arbitration: history and background, in Journal of international arbitration, v. 6, n. 2 1989, pp. 43-56.

NAÓN, HORACIO GRIGERA, Factors to consider in choosing an efficient arbitrator, in VAN DEN BERG, ALBERT (Ed.). Improving the efficiency of arbitration agreements and awards: 
40 years of application of the New York Convention, ICCA Congress Series n. 9 (Paris, 1998), The Hague: Kluwer Law International, 1999, pp. 186-313.

Nicholas, Geoff; Partasides, Constantine. LCIA Court decisions on challenges to arbitrators: a proposal to publish, in Arbitration international, v. 23, n. 1, 2007, pp. 1-41.

Nunes Pinto, José Emilio. Recusa e impugnação de árbitro, in Revista de arbitragem e mediação, v. 15, 2007, pp. 80-84.

Nunes, Dierle José Coelho. Processo jurisdicional democrático: uma análise crítica das reformas processuais. Curitiba: Juruá, 2008.

ÖHRSTRÖM, MARIE. Decisions by the SCC Institute regarding challenge of arbitrators, in Stockholm arbitration report, 2002, n. 1, pp. 35-57.

OPPETIT, BRUnO. Teoría del arbitraje (trad. Eduardo Silva Romero et al.). Colombia: Legis Editores, 2006.

Pagés, Juan Luis RequeJo. Jurisdicción e independencia judicial. Madrid: Centro de Estudios Constitucionales, 1989.

Parente, Eduardo de Albuquerque. Processo arbitral e sistema. São Paulo: Atlas, 2012.

PARK, WILlIAM W. Arbitrator integrity: the transient and the permanent, in San Diego law review, v. 46, 2009, pp. 629-703.

PARSONS, TALCOTT. On the concept of influence, in The public opinion quarterly, v. 27, 1963, pp. 37-62.

PAUlsson, Jan. Are unilateral appointments defensible?, in Kluwer arbitration blog, 02.04.2009; disponível no endereço elênico http://kluwerarbitrationblog.com/blog/2009/04/02/are-unilateral-appointments-defensible/; consulta em 21.02.2014.

Peerenboom, Randall; He, Xin. Dispute resolution in China: patterns, causes and prognosis, in East Asian Law Review, v. 4, 2009, pp. 1-61.

Peyrano, Jorge W. Sobre el activismo judicial, in Activismo y garantismo procesal. Córdoba: Academia Nacional de Derecho y Ciencias Sociales de Córdoba, 2009. 
Pinsolle, PhilipPe. Note sur l'arrêt de la Cour d'appel de Paris du 9 septembre 2010 (Consorts d'Allaire c/. SAS SGS Holding France), in ASA Bulletin, v. 29, 2011, pp. 198204.

PIZZI, JovinO. O conteúdo moral do agir comunicativo, São Leopoldo: Unisinos, 2005.

Platão. A república, livros VI e VII, disponíveis no endereço eletrônico http://www.gutenberg.org/files/1497/1497-h/1497-h.htm; consulta em 21.02.2014.

PlatÃo. Ética a Nicômano, livros IX e X, disponíveis no endereço eletrônico http://classics.mit.edu/Aristotle/nicomachaen.html; consulta em 21.02.2014.

Portanova, Rui. Princípios do processo civil, Porto Alegre: Livraria do Advogado, 1995.

Poudret, JEAn-FrançOIS; Besson, SÉBAstien. Comparative law of international arbitration, London: Sweet \& Maxwell, 2007.

Prata, ANA. Dicionário jurídico. v. I. 5. ed. Coimbra: Almedina , 2008.

PucCI, Adriana Noemi (Ed.). Arbitragem comercial internacional, São Paulo: LTr, 1998, pp. 112-137.

RAU, ALAN SCOTT. Integrity in private judging, in South Texas law review, v. 38, 1997, pp. 485-539.

Redfern, Alan; Hunter, Martin; Blackaby, Nigel; Partasides, Constantine. Redfern and Hunter on international commercial arbitration, 5. ed, New York: Oxford University, 2009.

; ; Law

and practice of international commercial arbitration, 4. ed. London: Sweet \& Maxwell, 2004

ReICHELt, Luis Alberto. O direito fundamental das partes à imparcialidade do juiz no direito processual civil, in Revista de processo, v. 227, 2014, pp. 105-122.

Revista direito ao ponto, ano 6, n. 8, p. 53.

ROBERT, JEAN. L'arbitrage, droit interne, droit international privé. 5. ed. Paris: Dalloz, 1983. 
ROGERS, CATHARINE A. Regulating international arbitrators: a functional approach to developing standards of conduct, in Stanford journal of international law, v. 41, 2005, pp. 53-121.

. The International Arbitrator Information Project: from an ideation to operation, in Kluwer arbitration blog; disponível no endereço eletrônico http://kluwerarbitrationblog.com/blog/2012/12/10/the-international-arbitrator-informationproject-from-an-ideation-to-operation/; consulta em 21.02.2014.

. The vocation of the international arbitrator, in American University international law review, v. 20, 2005, pp. 957-1020.

. Transparency in internatinal commercial arbitration, in University of Kansas law review, v. 54, 2006, pp. 1301-1337.

RoOs, CRISTIAN CONEJERO. The new chilean arbitration law and the influence of the model law, in Journal of international arbitration, v. 22, n. 2, 2005, pp. 149-162.

Rossein, Merrick T.; Hope, JENnIFER. Disclosure and disqualification standards for neutral arbitrators: how far to cast the net and what is sufficient to vacate an award, in St. John's law review, v. 81, 2007, pp. 203-257.

ROZAS, JosÉ CARLOS FERNÁNDEZ. Clearer ethic guidelines and comparative standards for arbitrators, in FeRnÁNDEZ-BALleSteros, Ángel, Miguel; ARIAS, DAVID. Liber amicorum Bernardo Cremades. Madrid: La Ley, 2010, pp. 413-449.

Contenido ético del oficio de árbitro, trabalho apresentado no Congreso Arbitraje La Habana 2010, pp. 1-35; disponível no endereço eletrônico http://www.ohadac.com/congres.html?file=content/ohadac/travaux/congres/Contenido\%20 etico $\% 20$ del $\% 20$ acceso $\% 20$ a $\% 201$ a $\% 20$ actividad $\% 20$ arbitral $\% 20 \% 5 \mathrm{BJ}$ ose $\% 20$ Carlos $\% 20$ Fernandez\%20Rozas\%5D.pdf; consulta em 21.02.2014.

RÚA, JUlio CÉSAR CUeTO. El “common law”: su estructura normativa; su enseñanza. Buenos Aires: Abeledo-Perrot, 1997.

Rubino-SAMmartano, MAURO. International arbitration law and practice, 2. ed. The Hague: Kluwer Law International, 2001. 
Rubins, NoAh; LAUterburg, Bernhard, Independence, impartiality and duty of disclosure in investment arbitration, in CHRISTINA KNAHR et al. (Ed.). Investment and commercial arbitration - similarities and divergences, Utrecht: Eleven International Publishing, 2010, pp. 153-180.

SAlgueIRO, SOPHIE. A independência e a imparcialidade do árbitro à luz da jurisprudência da Corte de Apelação de Paris confrontada à prática brasileira, in Revista de arbitragem e mediação, v. 32, 2012, pp. 373-387.

SANDERS, PIETER. The making of the Convention, in Enforcing arbitration awards under the New York Convention - experience and prospects, New York: United Nations, 1999, pp. 3-5.

SAndROni, PaUlo. Novíssimo dicionário de economia. São Paulo: Best Seller, 1999.

SANGIOVANNI, VAlERIO. Il rapporto contrattuale tra gli arbitri e le parti nel diritto tedesco, in I contratti, n. 8-9, 2005, pp. 827-837.

SANTOS, FERnANDo SiLVA MoREIRA DOS. Impedimento e suspeição do árbitro: o dever de revelação, in Revista de arbitragem e mediação, v. 35, 2012, pp. 35-68.

SCHERER, MATTHIAS. New case law from Austria, Switzerland and Germany regarding the IBA Guidelines on Conflicts of Interest in International Arbitration, in Transnational dispute management, v. 5, n. 4, 2008, pp. 1-14.

Scherer, Maxi, Goldsmith, Aren; Fléchet, Camille. Third party funding in international arbitration in Europe: part 1 - funders' perspectives, in Revue de droit des affaires internationales, n. 2, 2012, pp. 207-220; disponível no endereço eletrônico http://ssrn.com/abstract=2348737; consulta em 21.02.2014.

SCHERER, MAXI. Third-party funding in arbitration, in Commercial dispute resolution, maio de 2012, pp. 55-59.

SCHIMITT, RICHARD B. Suite sharing: friendship with winning lawyer imperils huge victory, in Wall Street Jounal, 14.02.1990, referido por PARK, WILLIAM W. Arbitrator integrity: the transient and the permanent, in San Diego law review, v. 46, 2009, p. 641, nota 31 . 
SChlosser, Peter F. L'impartialité e l'indépendance de l'arbitre en droit allemand, in VAN COMPERNOLLE, JACQUES et al. (Ed.). L'impartialité du juge et de l'arbitre, Bruxelles: Bruylant, 2006, pp. 299-314.

SCHNEIDER, MICHAEL E. Transfer of ownership: from the parties' respective cases to the case decided by the tribunal, disponível no endereço eletrônico http://www.arbitrationch.org/pages/en/asa/news-\&-projects/presidents-message/index.html\#.UxKnWbWYZMt; consulta em 21.02.2014.

SEguel, Alejandro Romero. La independencia e la imparcialidad en la justicia arbitral, in Revista chilena de derecho, v. 28, n. 3, 2001, pp. 509-535.

Shany, YuVAL. Squaring the circle? independence and impartiality of party-appointed adjudicators in international legal proceedings, in Loyola of Los Angeles international and comparative law review, v. 30, n. 3, 2008, pp. 473-490.

SHORE, LAURENCE. Disclosure and impartiality: an arbitrator's responsability vis-a-vis legal standards, in Dispute resolution journal, v. 57, n. 1, 2002, pp. 32-85.

SLAOUI, FATIMA-ZAHRA. The rising issue of 'repeat arbitrators': a call for clarification, in Arbitration international, v. 25, n. 1, 2009, pp. 103-119.

SMITH, ADAM. The theory of moral sentiments. Indianapolis: Liberty Fund, 1982.

SoAres, Guido Fernando Silva. Common law: introdução ao direito dos EUA, 1. ed (2a tir.), São Paulo: RT, 1999.

SouZA, ARTUR CÉSAR DE. A parcialidade positiva do juiz. São Paulo: RT, 2008.

SPACCAPElo, ChIARA. L 'imparzialità dell'arbitro. Milano: Giuffrè, 2009.

SPALDING, FRANCIS O. Selecting the arbitrator, what counsel can do. Trecho transcrito por ROGERS CATHERINE A. The vocation of the international arbitrator, in American university international law review, v. 20, 2005, p. 969.

STRENGER, IRINEU. Arbitragem comercial internacional. São Paulo: LTR, 1996.

Stuart Mill, John. Utilitarianism. 7. ed. London: Longmans, Green, And Co., 1879, disponível no endereço eletrônico http://www.gutenberg.org/files/11224/11224-h/11224h.htm; consulta em 21.02.2014. 
TAO, JingZHOU. Arbitration law and practice in China. 2. ed. Netherlands: Kluwer Law International, 2008.

TARUfFo, Michele. Note sull'imparzialità dell'arbitro di parte, in Rivista dell'arbitratto , 1997, p. 481-491.

Teitelbaum, Ruth; Walsh, Thomas W. The LCIA Court decisions on challenges to arbitrators: an introduction, in Arbitration international, v. 27, pp. 283-313.

TheOdoro Júnior, Humberto. Curso de direito processual civil, v. I, 51. ed. Rio de Janeiro: Forense, 2010.

; Nunes, Dierle José Coelho. Princípio do contraditório: tendências de mudança na sua aplicação, in Revista da Faculdade de Direito do Sul de Minas, v. 28, 2009, pp. 177-206.

TRAKMAN, LEON. "Legal traditions" and international commercial arbitration, in The american review of international arbitration, v. 17, 2006, pp. 1-43.

Trocker, Nicolò. Processo civile e costituzione: problemi di diritto tedesco e italiano. Milano: Giuffrè, 1974.

TRUSZ, JENNIFER A. Full disclosure? Conflicts of interest arising from third-party funding in international commercial arbitration, in Georgetown law jounal, v. 101, 2013, pp. 1649-1682.

TuCCI, José Rogério CRUZ E. Do relacionamento juiz-advogado como motivo de suspeição, in Revista dos Tribunais (São Paulo), São Paulo, v. 756, 1998, p. 69-76.

Vagts, DetLeV F. The international legal profession: a need for more governance?, in American journal of international law, v. 90, 1996, pp. 250-261.

VAN DEN BERG, ALBERT JAN. Dissenting opinions by party-appointed arbitrators in investment arbitration, in MAHNOUSH H. ARSANJANI et al. (ed.). Looking to the future: essays on international law in honor of W. Michael Reisman, Amsterdam: Martinus Nijhoff, 2010, pp. 821-843. 
VÁrady, Tibor; BARceló III, John J.; von Mehren, ARThur TAYlor. International commercial arbitration: a transnational perspective, 3. ed. New York: West Publishing, 2006.

VARGA, CSABA. The non-cognitive character of the judicial establishment of facts, in Koch, Hans-Joachim, Neumann, UlfRid. Legal System and practical reason. Stuttgart: Franz Steiner, 1994, pp. 230-239.

VEEDER, V. V. The English Arbitration Act 1996: its 10th and future birthdays, disponível no endereço eletrônico

http://www.expertguides.com/default.asp?Page=10\&GuideID=150\&CountryID=117; consulta em 21.02.2014.

Verçosa, Haroldo Malheiros Duclerc. Os "segredos" da arbitragem. São Paulo: Saraiva, 2013.

Vescovi, EnRIQUE. Teoría general del proceso, Bogotá: Temis, 1984.

VIETRI, RAPHAËL DE; DHARMANANDA, KANAGA. Impartiality and the issue of repeat arbitrators: a reply to Slaoui, in Journal of international arbitration, v. 28, 2011, pp.

WAINCYMER, JEFF. Reconciling conflicting rights in international arbitration: the right to choice of counsel and the right to an independent and impartial tribunal, in Arbitration International, v. 26, n. 4, 2010, pp. 597-623.

WALD, ARnOldo. A arbitragem e o mercado de trabalho dos advogados, in Revista de arbitragem e mediação, v. 32, 2012 , pp. 81-99.

WeISEMBERT, KIRSTEN. Peace is not the absence of conflict: a response to professor Rogers's article "Fit and function in legal ethics", in Wisconsin international law journal, v. 25, 2007, pp. 89-127.

WERNER, JACQUES. The Independence of party-appointed arbitrators: for a rule of reason, in Journal of international arbitration, v. 7, n. 2, 1990, pp. 5-6.

Whitesell, ANNE MARIE. Independence in ICC arbitration: ICC Court practice concerning the appointment, confirmation, challenge and replacement of arbitrators, in International Court of Arbitration Bulletin: 2007 Special Supplement - Independence of Arbitrators. Paris: ICC Publishing, 2008, pp. 7-40. 
Wijnen, Oto L. O DE WitT; Voser, NATHalie; RAO, N. The background information on the IBA Guidelines on Conflicts of Interests in International Arbitration, in Business law international, v. 5, 2004, pp. 433-458.

WINDSOR, KATHRYN A. Defining arbitrator evident partiality: the catch-22 of commercial litigation disputes, in Seton Hall Circuit review, v. 6, n. 1, 2009, pp. 191-217.

Yu, Hong-Lin; ShOre, LAURENCE. Independence, impartiality, and immunity of arbitrators - US and English Perspectives, in International and comparative law quarterly, v. 52, 2003, pp. 935-967.

ZuFFI, BEATRICE. L'arbitrato nel diritto inglese. Torino: Giappichelli, 2008. 


\section{RESUMO}

O presente estudo tem como objetivo superar as diversas noções genéricas a respeito da imparcialidade do árbitro e assim atribuir-lhe um conceito próprio, estabelecido a partir do reconhecimento da vital importância do exercício da influência das partes na relação jurídica processual.

O estudo parte da premissa de que todas as experiências pretéritas do árbitro (como as de qualquer indivíduo) constituem condição necessária para que este forme pré-conceitos e assim conheça e decida um conflito - e que, por isso, tais experiências e conceitos pretéritos sempre existem e sempre influenciam o julgador. Também é premissa de análise o ambiente institucional em que a arbitragem se desenvolve e no qual os profissionais buscam auferir capital simbólico que lhes possibilite êxito nas nomeações para a função de árbitro. Essas premissas impedem que se aprove a noção genérica da imparcialidade como "equidistância", "ausência de interesse próprio na solução do litígio" ou "ausência de outras influências no convencimento do árbitro além dos argumentos lançados pelas partes no litígio", e impõem o reconhecimento de um conteúdo apoiado na "inexistência de barreira à influência que os argumentos das partes exercerão na decisão do árbitro" (a despeito, portanto, de quaisquer outras influências às quais o julgador - como todo indivíduo - está sujeito).

A identificação de um conteúdo para a imparcialidade é, todavia, insuficiente para a solução de problemas práticos, razão pela qual o presente estudo sugere sua operacionalização por norma concreta - extraída de regras vinculantes que imponham um comportamento (art. 14, caput, da Lei de Arbitragem brasileira) ou um estado de coisas (art. 13, $\S 6^{\circ}$ da Lei de Arbitragem brasileira) - que atenda a certas premissas de estrutura e de conteúdo. As premissas de estrutura têm como finalidade garantir a coerência e coesão sistemáticas da norma concreta, ao passo que as premissas de conteúdo (extraídas de casos reais) buscam a coerência interna da norma, ou seja, a coerência entre o juízo hipotéticonormativo e o juízo sobre o evento fático subjacente. Essas premissas são examinadas à luz do ambiente institucional no qual a arbitragem se desenvolve, caracterizado principalmente pela interdependência e contínuo contato entre profissionais, a constante troca de papéis a 
que tais profissionais se sujeitam (ora como árbitros, ora como advogados) e a assimetria de informação.

Propostos um conteúdo e um método de operacionalizá-lo para a solução de casos concretos, o presente estudo procura desatrelar a imparcialidade - e seus efeitos - da noção geral de independência do árbitro, sem apelar para a imprecisa dicotomia subjetividadeobjetividade. Reconhece, ainda, que do árbitro são demandadas posturas diferentes daquelas preconizadas aos juízes, razão pela qual a aplicação de regras equiparativas (tal como o art. 14, caput, da Lei de Arbitragem brasileira), além de não esgotar todas as hipóteses de ataque à imparcialidade, deve ser precedida de diversas adaptações. Reconhece, também, o sentido e o alcance do binômio ciência-aceitação na prática arbitral. Por fim, o estudo trata da diversa natureza entre o dever de revelação e a imparcialidade impostos ao árbitro, de cujas violações derivam consequências também distintas. 


\section{ABSTRACT}

The present study aims to overcome several general notions concerning the impartiality of the arbitrator and thus gives it a proper concept, drawn from the recognition of the vital importance of parties to exercise influence on the procedural legal relationship.

The study assumes that all past experiences of the adjudicator (as any individual) constitute a necessary condition for him to create pre-conceptions and so understand and decide a conflict - and that therefore these experiences and past concepts always influence the adjudicator. The institutional environment in which the arbitration is developed and in which practitioners seek to derive symbolic capital that enables them to succeed in the nominations for the role of arbitrator is also a premise of analysis. This premise prevents from approving the generic notion of impartiality as "equidistance", "the absence of selfinterest in the outcome of the case" or "the absence of other influences in the convincing process of the adjudicator beyond the arguments submitted by the parties in dispute", and requires the recognition of content based on the "absence of barriers to the influence that the arguments of the parties shall exercise on the arbitrator's decision" (regardless of any other influences to which the judge - as any individual - is exposed) .

Identifying content for impartiality is, however, insufficient for the solution of actual problems, and due to that, the study suggests its operation by a norm - extracted from binding rules imposing conduct (art. 14, caput of Brazilian Arbitration Law) or a state of affairs (art. 13, § 6 of the Brazilian Arbitration Law) - that meets certain premise of structure and content. The premise of structure is designed to provide systematic consistency and cohesion of the norm, and the premise of content (drawn from actual cases) seeks internal consistency of the standard, i.e., the consistency between the description of the event anticipated in the norm and the description of the underlying factual event. This premise is examined in the light of the institutional environment in which the arbitration is developed, mainly characterized by interdependence and continuous contact between professionals, the constant exchange of roles among such professionals (either as arbitrators or as lawyers) and information asymmetry. 
Proposed both a content and a method to operationalize it for the solution of actual cases, this study seeks to release fairness - and its effects - from the general notion of independence of the arbitrator, without resorting to imprecise objectivity-subjectivity dichotomy. It also recognizes that the institutional environment requires postures from the arbitrators that differ substantially from those required from judges; due to this reason, the application of rules that apparently prescribe the same standards or behaviors for both (such as art. 14, caput, the Brazilian Arbitration Law) does not fill all the hypothesis capable of menacing the impartiality and must be preceded by various adaptations. It also recognizes the meaning and scope of the binomial information-acceptance in arbitral practice. Finally, the study addresses the diverse nature of the duty of disclosure and impartiality imposed on the arbitrator, whose respective violations also imply different consequences. 


\section{RIASSUNTO}

Il presente studio mira a superare diverse nozioni generali riguardanti l'imparzialità dell'arbitro e quindi dargli un concetto adeguato, tratto dal riconoscimento dell'importanza vitale dei partiti di esercitare un'influenza sul rapporto giuridico processuale .

Lo studio ipotizza che tutte le esperienze passate del giudice (come ogni individuo) costituiscono una condizione necessaria per lui a creare preconcetti e così capire e decidere un conflitto - e che quindi queste esperienze e concetti del passato influenzano sempre il giudice . Il contesto istituzionale in cui l'arbitrato è sviluppato e in cui gli operatori cercano di ricavare capitale simbolico che permette loro di avere successo nelle nomine per il ruolo di arbitro è anche una premessa di analisi. Queste premesse impediscono che approva l' idea generica di imparzialità come "equidistanza", "l'assenza di auto-interesse alla soluzione del caso" o " assenza di altri fattori nel processo convincente del giudice l'arbitro al di là gli argomenti addotte dalle parti in causa", e richiedono il riconoscimento dei contenuti basata sulla "assenza di barriere all'influenza che gli argomenti delle parti esercitano sulla decisione dell'arbitro" (a prescindere eventuali altre influenze a cui il giudice - come ogni individuo - è esposto) .

Identificare il contenuto di imparzialità è tuttavia insufficiente per la soluzione di problemi reali, e grazie a questo, lo studio suggerisce la sua operazionalizzazione da una norma concreta - estratta da regola vincolanti che impongono condotta (art. 14, caput, della Legge sull'Arbitrato brasiliana) o uno stato degli affari (art. 13, § 6, della Legge sull'Arbitrato brasiliana) - che soddisfa determinate premesse di struttura e contenuto. Le premesse della struttura cercano la coerenza sistematica e coesione dela norma concreta, e le premesse di contenuti (tratti da casi reali) cercano coerenza interna della norma, vale a dire, la coerenza tra la descrizione della manifestazione prevista nela norma e la descrizione dell'evento fattuale sottostante. Queste premesse sono esaminate alla luce del contesto istituzionale in cui si sviluppa l'arbitrato, prevalentemente caratterizzato da interdipendenza e contatto continuo tra i professionisti, il continuo scambio di ruoli tra tali professionisti (sia come arbitri o come avvocati) e asimmetria informativa. 
Proposto un contenuto e un metodo per rendere operativa la imparzialità per la soluzione di casi concreti, questo studio cerca separarla - ei suoi effetti - dalla nozione generale di indipendenza dell'arbitro, senza ricorrere a imprecisa dicotomia oggettività-soggettività. Riconosce inoltre che gli arbitri sono tenuti diverse posture da parte dei giudici, e per che l'applicazione di regole equiparatisti (come ad esempio l'art. 14, caput, Legge sull'Arbitrato brasiliana) non esaurisce tutte le possibilità di attacco di imparzialità e sarà preceduta da diversi adattamenti. Riconosce inoltre che il contesto istituzionale richiede posture da arbitri che differiscono sostanzialmente da quelli richiesti da giudici. Causa di questo motivo, l'applicazione di regole che, apparentemente, prescrivono le stesse norme o comportamenti per entrambi (come ad esempio l'art 14, caput, Legge sull"Arbitrato brasiliana) non riempie tutte le ipotesi in grado di minacciare l'imparzialità e deve essere preceduto da vari adattamenti. Lo studio riconosce anche il significato e la portata del binomio informazione-accettazione in pratica arbitrale. Infine, lo studio affronta la diversa natura del dovere di informazione e di imparzialità imposto all'arbitro, la cui rispettiva violazione anche fare sorgere conseguenze diverse. 